\title{
70 Lat Wydziału \\ Prawa i Administracji Uniwersytetu Łódzkiego
}


酱 


\title{
70 Lat Wydziału \\ Prawa i Administracji \\ Uniwersytetu Łódzkiego
}

\author{
pod redakcja \\ Agnieszki Liszewskiej \\ i Anny Pikulskiej-Radomskiej
}


Agnieszka Liszewska - Uniwersytet Łódzki, Wydział Prawa i Administracji

Zakład Prawa Karnego Materialnego, 90-232 Łódź, ul. Kopcińskiego 8/12

Anna Pikulska-Radomska - Uniwersytet Łódzki, Wydział Prawa i Administracji

Katedra Prawa Rzymskiego, 90-232 Łódź, ul. Kopcińskiego 8/12

\section{REDAKTOR WYDAWNICTWA UŁ}

Bogustaw Pielat

REDAKCJA TECHNICZNA

Leonora Wojciechowska

SKŁAD I ŁAMANIE

AGENT PR

\section{PROJEKT OKŁADKI}

Stämpfli Polska Sp. zo.o.

Zdjęcie wykorzystane na okładce: (C) Shutterstock.com

CC Copyright by Uniwersytet Łódzki, Łódź 2015

Wydane przez Wydawnictwo Uniwersytetu Łódzkiego

Wydanie I. W.06830.15.0.I

Ark. wyd. 16,0; ark. druk. 15,5

ISBN 978-83-7969-562-1

Wydawnictwo Uniwersytetu Łódzkiego

90-131 Łódź, ul. Lindleya 8

www.wydawnictwo.uni.lodz.pl

e-mail: ksiegarnia@uni.lodz.pl

tel. (42) 66558 63, faks (42) 6655862

Druk i oprawa: Quick Druk 


\section{Spis treści}

\section{ZARYS HISTORII WYDZIAŁU PRAWA UNIWERSYTETU ŁÓDZKIEGO}

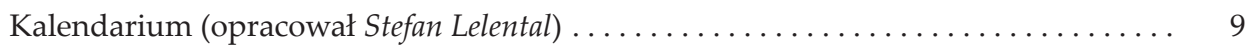

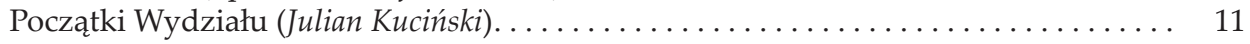

Wydział Prawa w latach 1945-1969 (Jan Waszczyński, Jerzy Wróblewski) . . . . . . . . . 15

Wydział Prawa w latach 1945-1995 (Jan Kodrębski). . . . . . . . . . . . . . . . . . . 21

Wydział Prawa i Administracji w latach 2008-2015 (Anna Rolczak).............. 29

\section{NASI MISTRZOWIE}

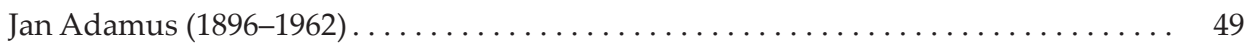

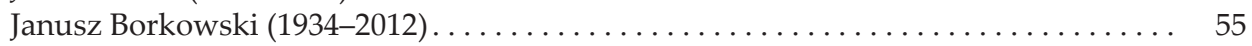

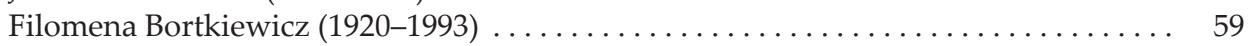

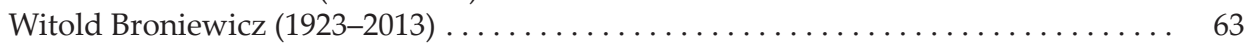

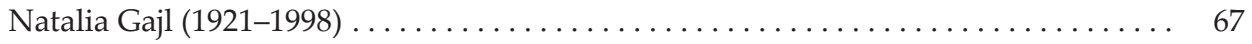

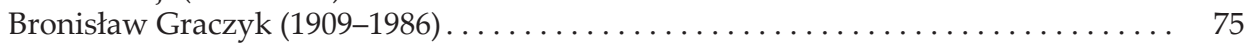



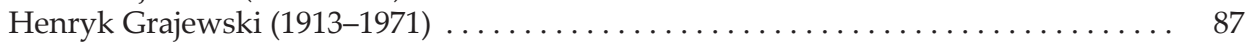

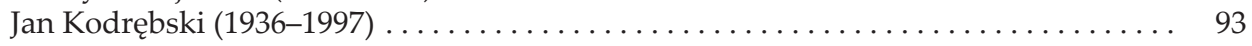

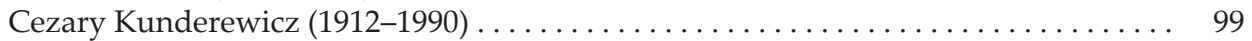

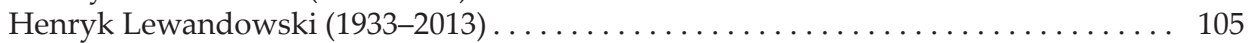

Marian Lisiewski $(1886-1965)$. . . . . . . . . . . . . . . . . . . . . . . . 109

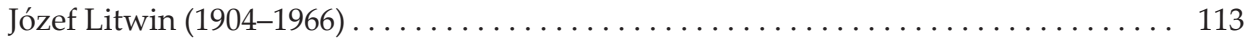

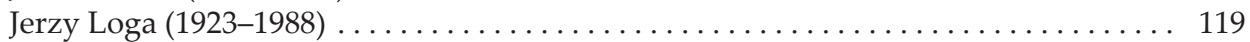

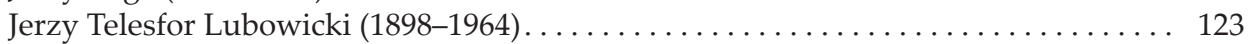

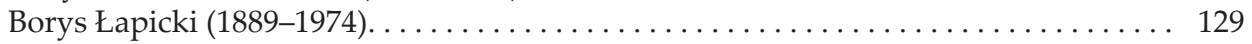

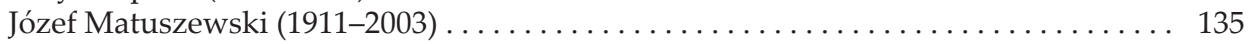

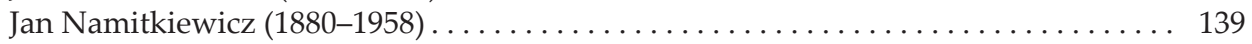

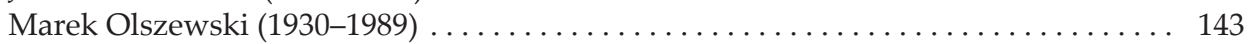

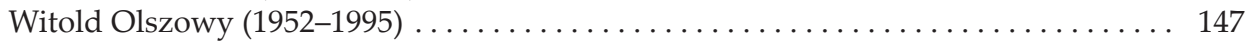

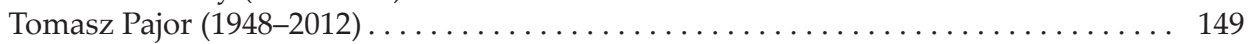

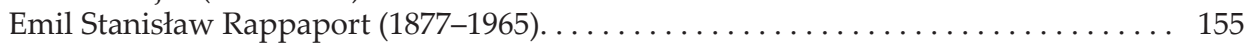

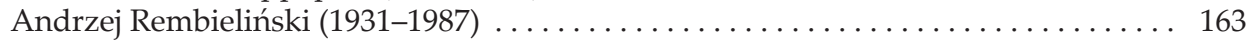

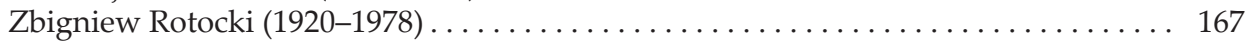

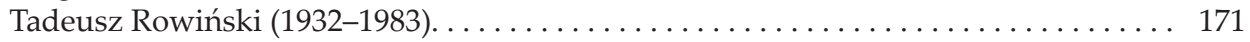

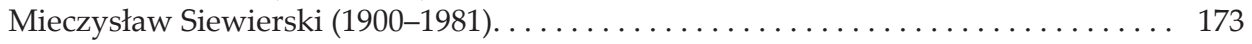

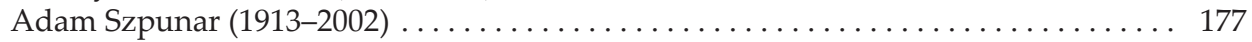

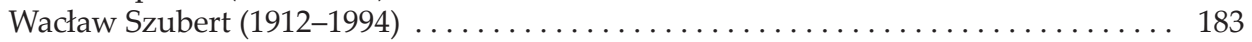

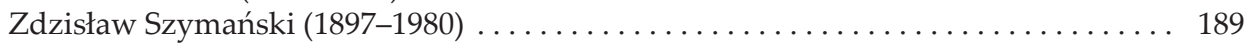


Spis treści

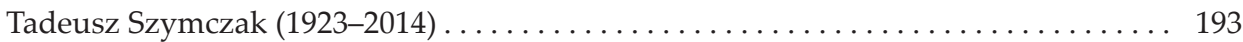

Stanisław Śreniowski $(1912-1957) \ldots \ldots \ldots \ldots \ldots \ldots \ldots \ldots \ldots$. . . . . . . . . . . . . . . . 197

Barbara Waldo (1925-1998) . . . . . . . . . . . . . . . . . . . . . . . . . . . . . . . 201

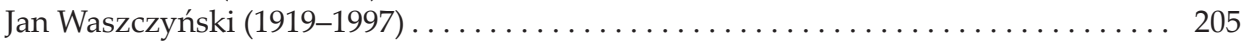

Bolesław Wilanowski (1885-1952) . . . . . . . . . . . . . . . . . . . . . 213

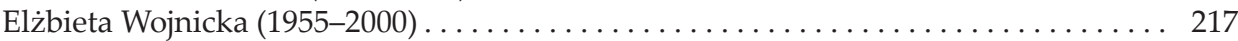










\section{I \\ Zarys historii Wydziału Prawa Uniwersytetu Łódzkiego}





\section{Kalendarium}

1945 - utworzenie Uniwersytetu Łódzkiego z Wydziałem Prawno-Ekonomicznym obejmującym trzy kierunki czteroletnich studiów magisterskich: prawno-ekonomiczny, prawno-sądowy i prawno-administracyjny.

1948 - likwidacja kierunków prawno-ekonomicznego i prawno-administracyjnego; zmiana nazwy wydziału na Wydział Prawa.

1949 - Wydział Prawa otrzymuje pierwszą własną siedzibę w zaadaptowanym na potrzeby dydaktyczne budynku pofabrycznym przy ul. Kopernika 55.

1949 - reforma studiów prawniczych, w ramach której dotychczasowe czteroletnie studia prawnicze zostały przekształcone na dwustopniowe - zawodowe studia trzyletnie oraz dwuletnie studia magisterskie, na które wstęp otwarty został dla wyróżniających się absolwentów studiów trzyletnich. W wyniku tej reformy na Wydziale Prawa UŁ uruchomiono jedynie studia trzyletnie (zawodowe).

1951/1952 - na Wydziale rozpoczyna działalność Ośrodek Konsultacyjny Studium Zaocznego Wydziału Prawa Uniwersytetu Warszawskiego, przeznaczony dla studentów zamieszkałych w Łodzi i województwie łódzkim. Z dniem 1 września 1956 r. Ośrodek Konsultacyjny przekształcono w Studium Zaoczne Wydziału Prawa UŁ.

1952/1953 - zniesienie systemu trzyletnich studiów zawodowych i dwuletnich studiów magisterskich, ponowne wprowadzenie czteroletnich studiów magisterskich. Absolwentom studiów trzyletnich umożliwiono uzupełnienie wykształcenia i uzyskanie stopnia magistra prawa, powołując na Wydziale osobne Studium Eksternistyczne, na którym w latach 1954-1965 stopień uzyskało 118 osób (na 176 przyjętych).

1959 - zmiana siedziby Wydziału, który przenosi się do gmachu zajmowanego wcześniej przez Bibliotekę Uniwersytecką przy ul. Składowej 59a (Collegium Iuridicum). 
1959/1960 - przedłużenie studiów prawniczych do lat pięciu (pięcioletni program studiów zmieniono jednak ponownie $\mathrm{w}$ roku akademickim 1965/1966 i zastąpiono programem czteroletnim). Na Wydziale rozpoczyna działalność Zawodowe Studium Administracyjne jako Ośrodek Konsultacyjny dla studentów Uniwersytetu Warszawskiego, zamieszkałych w Łodzi i województwie łódzkim. Od 1 czerwca 1964 r. Ośrodek Konsultacyjny przekształcony został w Zawodowe Studium Administracyjne na Wydziale Prawa UŁ.

1961 - w gmachu Collegium Iuridicum, w dawnych pomieszczeniach magazynowych Biblioteki Uniwersyteckiej, utworzono Bibliotekę Wydziału Prawa.

1966 - utworzono dwuletnie magisterskie studia administracyjne (Studium Administracji) dla absolwentów Zawodowych Studiów Administracyjnych.

1970 - zmiana oficjalnej nazwy na Wydział Prawa i Administracji, która wiązała się z utworzeniem stacjonarnych magisterskich studiów administracyjnych (zarządzenie Rektora UŁ z dnia 1 października 1970 r.).

1976 - oddano do użytku tzw. łącznik - budynek łączący Wydział Prawa i Administracji z Rektoratem, znajdowała się w nim aula, sale ćwiczeniowe oraz pomieszczenia dla pracowników.

101981 - 14 grudnia na Wydziale rozpoczął się strajk studencki kierowany przez Niezależne Zrzeszenie Studentów. 15 grudnia do budynku, także do dziekanatu, wkroczył oddział ZOMO.

1992 - Wydział otrzymał budynek przy ul. Uniwersyteckiej 3, do którego przeniesiono dziekanat oraz niektóre katedry.

1994 - otworzono studia wieczorowe, na które przyjmowano studentów bez egzaminu wstępnego. Spowodowało to olbrzymi wzrost liczby studentów studiujących na Wydziale Prawa i Administracji i pogorszenie sytuacji lokalowej. W efekcie władze Wydziału podjęły decyzję o budowie nowoczesnej auli, finansowanej częściowo z wpływów ze studiów wieczorowych.

1997 - oddano do użytku nowoczesna, wyposażoną w sprzęt audiowizualny aulę mieszczącą 560 studentów. Z czasem aula otrzymała imię Profesora Wacława Szuberta.

2000 - w budynku sąsiadującym z Aulą im. W. Szuberta uruchomiono nową bibliotekę wydziałowa, której nadano imię Profesora Jerzego Wróblewskiego.

2002 - przekazano do użytku nowy budynek Dziekanatu Wydziału Prawa i Administracji przy ul. Składowej 41/43. W budynku tym znalazła się też nowa sala Rady Wydziału.

2008 - Wydział Prawa i Administracji przeniósł się do nowego budynku przy ul. Kopcińskiego 8/12. 


\section{Początki Wydziału}

Sylwetki tódzkich uczonych. Profesor Teodor Mieczysław Vieweger, wyd. Łódzkie Towarzystwo Naukowe, Łódź 2001, z. 63, s. 19-21

\section{$[\ldots]$ \\ Wznowienie działalności Towarzystwa Przyjaciół Nauk w Lodzi i utworzenie Uniwersytetu Łódzkiego - Wolna Wszechnica Polska w 1945 r.}

8 marca 1945 r. Teodor Vieweger razem z profesorem Janem Dylikiem wznowili działalność Towarzystwa Przyjaciół Nauk w Łodzi. Dalsze wydarzenia sprawiły, że - przede wszystkim pod wpływem uczonych przybyłych do włókienniczego miasta ze Lwowa i z Warszawy - stowarzyszenie przekształcono w towarzystwo naukowe. Statut nowej organizacji o nazwie Łódzkie Towarzystwo Naukowe, zatwierdzony przez prezydenta Łodzi 24 stycznia 1948 r., został jednak opracowany również przy udziale byłych członków Towarzystwa Przyjaciół Nauk. W ten sposób, niezależnie od zmiany charakteru starej organizacji, Łódzkie Towarzystwo Naukowe stanowi kontynuację Towarzystwa Przyjaciół Nauk w Łodzi. Potwierdzeniem tego są wypowiedzi późniejszych prezesów Łódzkiego Towarzystwa Naukowego, na przykład profesorów Witolda Śmiecha i Stanisława Liszewskiego. Postać profesora Jana Dylika - najpierw sekretarza generalnego Towarzystwa w latach 1945-1966, a następnie jego prezesa w latach 1966-1973 - jest symbolem ciągłości personalnej starego i nowego Towarzystwa ${ }^{1}$.

${ }^{1}$ S. Liszewski, Łódzkie Towarzystwo Naukowe, „Kronika Miasta Łodzi” 1994, z. 1, s. 149-160; Witold Śmiech (Eódzkie Towarzystwo Naukowe, [w:] Słownik polskich towarzystw naukowych, red. D. Smoleński, t. I, red. L. Łoś, Wrocław 1978, s. 60) napisał, że: „Łódzkie Towarzystwo Naukowe utworzone w 1936 r. [...] do 1946 r. występowało pod nazwą Towarzystwo Przyjaciół Nauk w Łodzi"; J. Kuciński, Łódzkie Towarzystwo Naukowe w latach 1936-1996, cz. I: Studia, s. 58-59, 66-71; cz. II: Materiały, s. 205-216, ŁTN, Łódź 1996. 
XXX

Po przybyciu do Łodzi w lutym 1945 r., T. Vieweger powrócił do koncepcji przekształcenia Wolnej Wszechnicy Polskiej w Uniwersytet, tym razem $\mathrm{z}$ siedzibą $\mathrm{w}$ Łodzi. W ten sposób wychodził naprzeciw oczekiwaniom łodzian, którzy do 1943 r. działali w tajnej Komisji Organizacji Szkolnictwa Wyższego w tym mieście. Byli to, między innymi, adwokat Henryk Kurnatowski, doc. Tadeusz Pawlikowski oraz prof. Bolesław Wilanowski. 17 lutego uczeni zamieszkali w Łodzi zaznajomili się ze sprawozdaniami T. Viewegera i B. Wilanowskiego na temat stanu prac nad utworzeniem łódzkiej „uczelni akademickiej”. Zaprezentowali oni dwa sprzeczne projekty. Według pierwszego z nich nowa uczelnia powinna być oparta na Wolnej Wszechnicy Polskiej w Warszawie. Drugi referent, były dziekan Wydziału Prawnego Uniwersytetu w Wilnie, opowiadał się za wyższą szkoła, która posiadałaby kierunki handlowe, medyczne, politechniczne i rolnicze. Po pewnym czasie T. Vieweger, stojący wówczas na czele Komitetu Organizacyjnego Wyższych Uczelni w Łodzi, kompromisowo zgodził się na włączenie do tej uczelni kierunków medycznych i w marcu objął przewodnictwo Komisji Organizacyjnej Wydziału Lekarskiego Uniwersytetu Łódzkiego.

Wykłady na tym Uniwersytecie rozpoczęto zanim został zatwierdzony przez Krajową Radę Narodową ale za zgodą ministra oświaty Stanisława Skrzeszewskiego. Od 15 marca rozpoczęto zapisy na studia w Uniwersytecie Łódzkim, a w kwietniu 600 osób zapisało się na tzw. Kurs przyśpieszony na wydziałach medycznych. 22 marca zaczęły się zajęcia na wydziałach: Humanistycznym, Matematyczno-Przyrodniczym i Pedagogicznym.

Nieco wcześniej, 27 marca, T. Vieweger przedstawił Ministerstwu Oświaty skład pracowników naukowych i dydaktycznych w nowej uczelni o nazwie: Państwowy Uniwersytet w Łodzi - Wolna Wszechnica Polska².

${ }^{2}$ Organizacja Uniwersytetu w Łodzi [konferencja 7 II 1945 r.], „Dziennik Łódzki”, 11 II 1945, nr 10, s. 4; Organizacja Uniwersytetu w Łodzi: Wolna Wszechnica Polska zostanie odpowiednio rozbudowana, „Głos Ludu”, 21 II 1945, nr 43 (82), s. 4; Kształtowanie władzy ludowej w Łodzi i województwie łódzkim w 1945 roku: wybór źródeł, oprac. G. Adamczewska, M. Bandurka, E. Chobot, M. Ojrzyńska, Warszawa-Łódź 1985, s. 75-77, 108-109, 174-176; Biblioteka Akademii Medycznej w Łodzi, [Franciszek Kiciński], Materiaty do dziejów wydziałów medycznych Uniwersytetu Łódzkiego i Akademii Medycznej w Łodzi 1945-1955, zebrat oraz wspomnieniami uzupetnit [...], oprac. M. Bandurka, Łódź 1963 [mpis], s. 1-12; Materiały do dziejów wydziatów medycznych Uniwersytetu Łódzkiego i Akademii Medycznej w Łodzi w latach 1945-1955, cz. I: Wspomnienia Franciszka Kicińskiego, oprac. M. Bandurka, „Annales 
22 maja 1945 r. prof. dr Teodor Mieczysław Vieweger, wracając ze stolicy do Łodzi, zginął tragiczną śmiercią w wypadku samochodowym w Ożarowie Mazowieckim k. Warszawy. W stolicy finalizował utworzenie Uniwersytetu Łódzkiego. Został pochowany 7 czerwca na Starym Cmentarzu Katolickim w Łodzi ${ }^{3}$. W cztery dni później podczas Akademii Żałobnej prof. dr Natalia Gąsiorowska powiedziała, między innymi:

Odszedł od nas „Nasz Rektor” [...] tak Go zwykle nazywaliśmy na Wolnej Wszechnicy Polskiej, bo był złączony ze swą uczelnią najściślejszymi węzłami. Mieliśmy poczucie, że ani nasza instytucja bez rektora Viewegera, ani rektor Vieweger bez Wszechnicy istnieć nie mogą. Rektor stał z całą bezwzględnością na straży wysokiego poziomu naukowego i wychowawczego uczelni. [...] nie był niewolnikiem doktryny: tolerancja Jego była głęboka i szeroka. Był głębokim patriotą polskim, był szczerym, zdecydowanym demokratą... ${ }^{4}$

Na mocy uchwały Rady Państwa 22 lipca 1950 r. T. Vieweger został pośmiertnie odznaczony Krzyżem Oficerskim Orderu Odrodzenia Polski ${ }^{5}$.

Tuż przed śmiercią T. Vieweger otrzymał nominację ministra oświaty na rektora Uniwersytetu Łódzkiego. Trudno przesądzać, czym byłaby

Academiae Lodzensis" 1987, t. XXVII, s. 69-70; J. Muszkowski, Komitet Organizacyjny Uczelni Państwowej w Łodzi (marzec-czerwiec 1945), [w] Materiały do dziejów Uヒ (1945-1950), red. B. Baranowski, K. Duda-Dziewierz, Łódź 1952, s. 29, 31-34, 37; M. Bandurka, Narodziny Łodzi akademickiej, „Acta Universitatis Lodziensis” 1987, Folia Historica 30, s. 142-151; B. Baranowski, K. Baranowski, Pierwsze lata Uniwersytetu Łódzkiego (1945-1949), Łódź 1985; Z. S. Dylik, Uniwersytet Łódzki w pierwszej fazie organizacji, „Życie Szkoły Wyższej” 1987, nr 3, s. 70-73.

${ }^{3}$ T. Vieweger był dwukrotnie żonaty. Najpierw ożenił się ze swoją asystentką Jadwiga z z którą doczekał się dwóch synów: Andrzeja i Oskara; ten ostatni miał troje dzieci: Marię, Tadeusza i Tomasza. Później, w 1936 r., poślubił swoją sekretarkę Hannę (vel Annę) Dobek. Rozmowa telefoniczna z żoną Oskara Viewegera - Anną z dn. 12 X 2001 r.; Skład osobowy i spis wykładów [Wolnej Wszechnicy Polskiej w Warszawie] za rok akademicki 1936/37, Warszawa 1936, s. 21; por. ibidem, za lata 1927/1928-1935/1937.

4 Archiwum Uniwersytetu Łódzkiego, sygn. 2997, Akademia Żałobna ku czci śp. Rektora T. Viewegera, Polska Agencja Prasowa „Polpress”, 11 VI 1945, kartka nr 16; tamże znajdują się klepsydry zawiadamiające o śmierci T. Viewegera, podpisane przez jego rodzinę i Bratnią Pomoc Państwowego Uniwersytetu w Łodzi, kk. nlb.; ibidem, "Zaświadczenie” z dn. 9 II 1957 r., wydane przez Rektora Uniwersytetu Łódzkiego, w którym wymieniono Ożarów k. Sochaczewa jako miejsce śmierci T. Viewegera, kk, nlb.

5 Archiwum Uniwersytetu Łódzkiego, sygn, 2997, „Zaświadczenie” z dn. 9 II 1957 r., wydane przez Rektora Uniwersytetu Łódzkiego, kk. nlb.; por. „Monitor Polski”, 29 VII 1950, nr A-85. 
ta uczelnia, gdyby nie przedwczesna śmierć Jej założyciela. Według opinii T. Kupczyńskiego, T. Vieweger pragnął przywrócić ideę uniwersytetu miejskiego w Warszawie jako kontynuatora Wolnej Wszechnicy Polskiej ${ }^{6}$. Niezależnie od pierwotnego kształtu dzisiejszy Uniwersytet Łódzki zawdzięcza w dużym stopniu swoje powstanie T. Viewegerowi ${ }^{7}$. $[\ldots]$

6 T. Kupczyński, Teodor Vieweger, „Przegląd Historyczno-Oświatowy” 1971, nr 1, s. 80; Adam Bieńkowski, Kto był pierwszym rektorem UŁ?, „Dziennik Łódzki”, 8 VI 1995, nr 133, s. 5.

724 V 1945 r. Krajowa Rada Narodowa zatwierdziła dekret Rady Ministrów o utworzeniu Uniwersytetu Łódzkiego, bez umieszczenia w jego nazwie członu: „Wolna Wszechnica Polska"; 3 lipca tego roku minister oświaty, Czesław Wycech mianował na rektora nowej uczelni prof. dr. Tadeusza Kotarbińskiego. Z. S. Dylik, Uniwersytet Łódzki..., s. 84. W uznaniu zasług T. Viewegera dla rozwoju łódzkiego środowiska naukowego, w tym budowy gmachu Wolnej Wszechnicy Polskiej w Łodzi, w którym działał później Wydział Ekonomiczno-Socjologiczny UŁ - Rada tego wydziału, na wniosek jej dziekana, doc. dr. Witolda Lejmana, 24 V 1990 r. nadała auli Wydziału imię Teodora Viewegera. Akta bieżące Dziekanatu Wydziału Ekonomiczno-Socjologicznego UŁ. 
Jan Waszczyński, Jerzy Wróblewski

\section{Wydział Prawa w latach 1945-1969}

Wydziat Prawa, zarys historii Wydziału, [w:] Uniwersytet Łódzki 1945-1970, red. Antonina Kłoskowska, wyd. PWN Oddział w Lodzi, Łódź 1970, s. 121-124

\section{Zarys historii Wydziału}

W chwili formalnego powołania do życia Uniwersytetu Łódzkiego przez dekret z dnia 24 maja 1945 r., istniejący już faktycznie od marca 1945 r. Wydział Prawno-Ekonomiczny obejmował trzy kierunki studiów: prawno-ekonomiczny, prawno-sądowy i prawno-administracyjny. Zespół wykładowców na Wydziale stanowili profesorowie różnych uniwersytetów polskich, którym udało się przetrwać lata okupacji, m.in. T. Kotarbiński, J. Namitkiewicz, B. Wilanowski, a także - wybitni przedstawiciele praktyki sądowej, jak A. Mogilnicki, E. St. Rappaport, M. Siewierski, L. Domański, M. Szerer, J. Jamontt. Wydział nie posiadał początkowo własnego lokalu i zajęcia prowadzone być musiały w lokalach szkół i innych instytucji. W związku z utworzeniem sieci wyższych szkół ekonomicznych, w 1948 r. zlikwidowano na Wydziale kierunek prawno-ekonomiczny i prawno-administracyjny; Wydział zmienił wówczas swą nazwę na obecną. W $1949 \mathrm{r}$. Wydział otrzymał pierwszą własną siedzibę przy ul. Kopernika $55 \mathrm{w}$ zaadaptowanym na potrzeby dydaktyczne budynku pofabrycznym. W tymże roku studia prawnicze poddane zostały w całym kraju gruntownej reformie. Jednolite dotąd studia czteroletnie przekształcono w studia dwustopniowe, a mianowicie - zawodowe studia trzyletnie mające dostarczyć w możliwie krótkim czasie fachowców dla aparatu sądowo-prokuratorskiego oraz dwuletnie studia magisterskie, na które dostęp otwarty został dla wyróżniających się absolwentów studium trzyletniego. 
W wyniku reformy na Wydziale uruchomiono jedynie studium trzyletnie. Reforma studiów dotyczyła jednakże nie tylko programu zajęć. Przeobraziła ona również stosowany dotychczas, wzorowany na przedwojennym, system rekrutacji i tok nauczania. Wprowadzono po raz pierwszy planową rekrutację i limity przyjęć na pierwszy rok studiów, ustanowiono zakaz pracy zarobkowej dla studentów i rozbudowano jednocześnie system stypendialny oraz inne formy pomocy materialnej dla młodzieży studiującej, podniesiono liczbę godzin wykładów i ćwiczeń przy jednoczesnym nałożeniu na młodzież administracyjnie egzekwowanego obowiązku uczęszczania na wykłady (tzw. dyscyplina studiów), a wreszcie objęto szkoleniem wojskowym w trakcie trwania studiów mężczyzn podlegających obowiązkowi wojskowemu (Studium Wojskowe). System trzyletnich studiów zawodowych i dwuletnich studiów magisterskich zniesiony został w roku akademickim 1952/1953 i zastąpiony ponownie czteroletnimi studiami magisterskimi. Wraz z likwidacją studiów trzyletnich zniesiono też formalnie rozumianą dyscyplinę studiów. Utrzymano natomiast w mocy pozostałe zmiany wprowadzone przez reformę z 1949 r. Pod względem programu przywrócone czteroletnie magisterskie studia prawnicze stały się syntezą dotychczasowych studiów dwustopniowych. Absolwentom studiów trzyletnich otworzono możliwość uzupełnienia wykształcenia i uzyskania stopnia magistra praw, powołując na Wydziale osobne Studium Eksternistyczne, na którym w latach 1954-1965 stopień ten uzyskało 118 osób (ze 178 przyjętych na Studium).

Od roku akademickiego 1951/1952 na Wydziale rozpoczyna działalność Studium Zaoczne. Studium to początkowo funkcjonuje jako Ośrodek Konsultacyjny Studium Zaocznego Wydziału Prawa Uniwersytetu Warszawskiego, przeznaczony dla studentów zamieszkałych w Łodzi i województwie tódzkim. Od dnia 1 września 1956 r. Ośrodek Konsultacyjny przekształcony zostaje w Studium Zaoczne Wydziału Prawa Uniwersytetu Łódzkiego.

Dalsze zmiany w życiu Wydziału przynosi 1960 r., kiedy to Wydział zmienia siedzibę i przenosi się do gmachu przy ul. Narutowicza 59a, w którym pozostaje do dnia dzisiejszego.

W tym samym okresie dokonują się dalsze zmiany w organizacji studiów prawniczych. Od roku akademickiego 1959/1960 program studiów przedłużony zostaje do lat pięciu i odpowiednio wzbogacony o szereg nowych przedmiotów. Pięcioletni program studiów zmieniono jednak ponownie w roku akademickim 1965/1966 i zastąpiono go programem czteroletnim. Na skutek tego w latach 1965-1969 na Wydziale kształcenie prowadzone było równolegle systemem pięcioletnim (dla roczników, które rozpoczęły studia przed rokiem akademickim 1965/1966) oraz systemem 
czteroletnim (dla roczników, które rozpoczęły studia w latach 1965/1966 i następnych).

W 1959/1960 r. w ramach Wydziału utworzono nowy kierunek, Zawodowe Studium Administracyjne, zorganizowane przede wszystkim z myślą o podniesieniu kwalifikacji pracowników rad narodowych oraz administracji gospodarczej. Podobnie jak w przypadku Studium Zaocznego, Zawodowe Studium Administracyjne rozpoczęło swą działalność jako Ośrodek Konsultacyjny dla studentów Uniwersytetu Warszawskiego, zamieszkałych w Łodzi i województwie łódzkim. Ośrodek ten od 1 czerwca 1964 r. przekształcony został w Zawodowe Studium Administracyjne na Wydziale Prawa Uniwersytetu Łódzkiego. Rozwinięciem systemu kształcenia, zapoczątkowanego na Zawodowym Studium Administracyjnym jest utworzone na Wydziale Prawa z dniem 1 października 1966 r. dwuletnie magisterskie Studium Administracji dla absolwentów Zawodowego Studium Administracyjnego.

U schyłku lat sześćdziesiątych Wydział Prawa składał się z czterech studiów: a) Studium tzw. stacjonarnego, dla młodzieży niepracującej, b) Studium Zaocznego, c) Zawodowego Studium Administracyjnego, d) Studium Administracji. Na wszystkich kierunkach kształci się łącznie 1547 studentów, z czego na Studium Stacjonarnym - 770 osób, na Studium Zaocznym - 426 osób, na Zawodowym Studium Administracyjnym - 270 osób, na Studium Administracji - 81 osób.

W tym samym okresie na Wydziale działa 14 Katedr, których kierownikami są: Katedra Prawa Administracyjnego - vacat (kurator W. Szubert); Katedra Prawa Cywilnego - A. Szpunar; Katedra Prawa Finansowego - N. Gajl; Katedra Historii Państwa i Prawa Polskiego - H. Grajewski; Katedra Prawa Karnego - St. Pławski; Katedra Prawa Międzynarodowego Publicznego - Z. Rotocki; Katedra Prawa Państwowego - Z. Izdebski; Katedra Postępowania Cywilnego - W. Broniewicz; Katedra Postępowania Karnego - M. Siewierski; Katedra Powszechnej Historii Państwa i Prawa - J. Matuszewski; Katedra Prawa Pracy - W. Szubert; Katedra Prawa Rolnego - J. St. Piątowski; Katedra Prawa Rzymskiego - C. Kunderewicz; Katedra Teorii Państwa i Prawa - J. Wróblewski.

W ramach Wydziału od 1960 r. funkcjonuje Biblioteka Wydziału Prawa (kierownik mgr E. Kamieńska), która według pierwotnych zamierzeń gromadzić miała przede wszystkim pomoce naukowe dla studentów, jednakże - dzięki energii kierownictwa - z biegiem lat wyszła znacznie poza swoją dydaktyczną rolę i skupiła bogaty zespół czasopism prawniczych oraz wydawnictw zwartych zarówno krajowych, jak i zagranicznych. 
Zespół pracowników naukowo-dydaktycznych Wydziału składa się z czterech profesorów zwyczajnych, czterech profesorów nadzwyczajnych, 11 docentów, dwu wykładowców, 13 adiunktów, 15 starszych asystentów, sześciu asystentów i dwu stażystów - łącznie z 57 osób.

Funkcje dziekanów pełnili kolejno: B. Łapicki w latach 1945/1946, B. Wilanowski - 1946/1948; J. Namitkiewicz - 1948/1949 i 1949/1950; A. Szpunar - 1950/1953; W. Szubert - 1953/1955 i 1965/1969; J. Wróblewski - 1955/1956 i 1962/1965; R. Bierzanek- 1956/1957; J. St. Piątowski1957/1962; J. Tylman od 1969 r.

Prodziekanami byli kolejno: B. Łapicki, J. Litwin, W. Szubert, J. Wróblewski, J. St. Piątowski, R. Rajkowski, H. Grajewski, J. Tylman.

Dorobek dydaktyczny Wydziału niełatwo jest wyrazić w liczbach. Pewne pojęcie o nim dać może liczba absolwentów, którzy ukończyli studia w latach 1945-1969. Liczba ta wynosi ogółem 3739 osób, z czego przypada na:

studia stacjonarne

Studium Zaoczne

Studium Eksternistyczne

Zawodowe Studium Administracyjne

Studium Administracji
3049 osób;

359 osób;

118 osób;

161 osób;

52 osoby.

W 25-leciu habilitację uzyskało 13 osób, a mianowicie: S. Śreniowski, Z. Szymański, H. Grajewski, Z. Rotocki, N. Gajl, W. Broniewicz, J. Tylman, J. Nowacki, I. Grajewska, T. Szymczak, J. Waszczyński, B. Lewaszkiewicz-Petrykowska, H. Popławski. Prawie wszyscy habilitanci wywodzą się z grona pracowników naukowo-dydaktycznych Wydziału Prawa Uniwersytetu Łódzkiego i w zespole tym po habilitacji zostali.

W tym samym okresie przeprowadzono na Wydziale 58 przewodów doktorskich zakończonych nadaniem tytułu naukowego doktora, z czego sześć doktoratów nadano w Katedrze Prawa Administracyjnego, sześć w Katedrze Prawa Cywilnego, sześć w Katedrze Prawa Finansowego, dziewięć w Katedrze Prawa Karnego, trzy w Katedrze Prawa Międzynarodowego Publicznego, sześć w Katedrze Historii Państwa i Prawa Polskiego, siedem w Katedrze Postępowania Karnego, sześć w Katedrze Prawa Pracy, dwa w Katedrze Teorii Państwa i Prawa, siedem - w Katedrach pozostałych.

Szereg różnych kontaktów utrzymuje Wydział Prawa z łódzkim środowiskiem prawniczym. Kontakty te wyrażają się m.in. w postaci seminariów prowadzonych w poszczególnych Katedrach przy aktywnym udziale przedstawicieli praktyki, wspólnie podejmowanych badań, konsultacji i prelekcji dotyczących zwłaszcza bieżących prac kodyfikacyjnych, w których wielu pracowników naukowych Wydziału aktywnie uczestniczy. 
Przytoczone dane stanowią syntezę wieloletniego wysiłku naukowego, organizacyjnego i dydaktycznego włożonego przez pracowników naukowo-dydaktycznych i administracyjnych Wydziału. Tej długotrwałej, ofiarnej i kolektywnej pracy Wydział Prawa zawdzięcza swój rozwój i obecny stan. Powstanie aktywnego, świadomego swych obywatelskich obowiązków środowiska prawniczego zarówno w samej Łodzi, jak i wielu innych okręgach naszego Kraju jest również w dużym stopniu efektem tego wysiłku.

$[\ldots]$ 



\section{Wydział Prawa w latach 1945-1995}

Wydziat Prawa i Administracji Uniwersytetu Łódzkiego w latach 1945-1995, "Acta Universitatis Lodziensis” 1997, Folia Iuridica 64, Prawo polskie w II połowie XX wieku. Rola Wydziału Prawa Uniwersytetu Łódzkiego w polskiej transformacji, s. 9-15

\section{$[\ldots]$}

Uniwersytet Łódzki powstał w mieście nie zniszczonym przez wojnę, w którym, przynajmniej teoretycznie, nauka i uczeni mogli liczyć na znalezienie elementarnych warunków do pracy i życia. Jak się okazało, władze tak miejskie, jak i centralne, nie okazały tworzonemu Uniwersytetowi pomocy, na którą zasługiwał ${ }^{1}$. Jak wiadomo, rektorat naszej uczelni ciągle mieści się w przydzielonym jej przed pięćdziesięciu laty, dość przypadkowo, budynku miejskich wodociągów. Tym niemniej w 1945 r., gdy Warszawa i Wrocław leżały w gruzach, Łódź skupiła wielu przedwojennych wykładowców uniwersyteckich, szukających po wojennych przejściach, najczęściej tragicznych, stabilizacji i bezpieczeństwa, a na początek jakiegoś mieszkania.

Uniwersytet Łódzki zakładano, jak wiadomo, wykorzystując przedwojenne tradycje Wolnej Wszechnicy Polskiej². Jej ostatni rektor, Teodor Vieweger, był jego organizatorem. Śmierć profesora Viewegera w wypadku samochodowym, jeżeli nie całkiem przekreśliła, to bardzo osłabiła więź nowo powstałej uczelni z tą wszechnicową tradycją. Miała ona jednak pewne znaczenie. Wolna Wszechnica Polska, w skład której wchodził wydział prawny, była w przedwojennej Polsce w istocie jedyną wyższą uczelnią o znacznej przewadze postaw liberalnych i wyraźnej obecności

${ }^{1}$ B. Baranowski, K. Baranowski, Trudne lata Uniwersytetu Łódzkiego (1949-1956), Łódź 1990, s. 16-18.

2 Z. Skubała-Tokarska, Społeczna rola Wolnej Wszechnicy Polskiej, Wrocław 1967. 
przedstawicieli lewicy tak wśród wykładowców, jak i studentów. Charakter polityczny tej uczelni nie był zbyt jasno zaznaczony, ale atmosfera na niej panująca różniła się znacznie od prawicowej atmosfery uniwersytetów polskich międzywojennego dwudziestolecia, zwłaszcza ich wydziałów prawa, zdominowanych przez prawicę polityczną. Wśród profesorów WWP liczni byli reprezentanci myśli liberalnej, a nawet lewicowej. Była ona też z tego względu przedmiotem brutalnych ataków środowisk prawicowych, silnie zresztą przeceniających jej lewicowość ${ }^{3}$. Wolna Wszechnica Polska powołała w 1928 r. na terenie Łodzi swój oddział, który był pierwszą działającą $w$ tym mieście autentyczną wyższą uczelnią. Swój rozwój w Łodzi uczelnia zawdzięcza $\mathrm{w}$ istotnej mierze poparciu finansowemu łódzkiego samorządu miejskiego, który docenił wówczas znaczenie szkolnictwa wyższego dla miasta. Stosunkowo wysoka subwencja (100 000 zł) wypłacana przez władze miejskie uczelni została zakwestionowana w 1935 r., gdy władzę w mieście przejęły ugrupowania prawicowe, odnoszące się do WWP wrogo ze względu na jej liberalizm ${ }^{5}$.

Pojawienie się na wydziale prawa UŁ kilku przedwojennych pracowników WWP, jak jej ostatni prorektor, profesor Borys Łapicki, profesor Emil Stanisław Rappaport, profesor Artur Żabicki czy profesor Janusz Jamontt $^{6}$, a także dr Wacław Szubert, miało pewnie znaczenie dla nadania wydziałowi określonego liberalnego charakteru. W chwili powstawania, tj. na wiosnę 1945 r., większość kadry Uniwersytetu Łódzkiego stanowili, zgromadzeni dość przypadkowo, przedwojenni wykładowcy wyższych uczelni, które bądź przestały istnieć (Wilno, Lwów), bądź leżały w ruinach (Warszawa). W skład nowo powstałego wydziału weszli uczeni znani i zajmujący eksponowaną pozycję $\mathrm{w}$ nauce, jak profesor prawa rzymskiego Borys Łapicki $i^{7}$ i profesor historii prawa Bolesław Wilanowski ${ }^{8} \mathrm{z}$ dawnego Uniwersytetu Stefana Batorego, a także wybitni uczeni praktycy, przed wojną związani luźniej ze środowiskiem akademickim, jak profesor prawa karnego Mieczysław Siewierski ${ }^{9}$, przedwojenny prokurator i wysoki

${ }^{3}$ J. Chałasiński, Uniwersytet Łódzki w trzecim roku reformy studiów akademickich, Łódź 1952, s. 54-55.

${ }^{4}$ K. Baranowski, Oddział Wolnej Wszechnicy Polskiej w Łodzi 1928-1939, Warszawa 1939.

${ }^{5}$ J. Chałasiński, Uniwersytet Łódzki...; K. Baranowski, Oddział..., s. 116-117.

${ }^{6}$ A. Peretiatkowicz, M. Sobeski, Wspótczesna kultura polska, Poznań 1932, s. 84; K. Baranowski, B. Baranowski, Pierwsze lata Uniwersytetu Łódzkiego (1945-1949), Łódź 1985, s. 107.

7 J. Kodrębski, Borys Łapicki (1889-1974), „Zeszyty Naukowe UŁ” [dalej: ZNUŁ] 1962, S. I, z. 26, s. 269-282.

8 R. Bar, Prof. Bolestaw Wilanowski (1885-1952), „Prawo Kanoniczne” 1979, nr 1-2, s. 259-263; Polscy kanoniści (wiek XIX i XX), red. R. Bar, Warszawa 1981, t. II, s. 228-229.

9 J. Waszczyński, Mieczysław Siewierski 1900-1981, „Państwo i Prawo” 1982, nr 3-4, s. $102-104$. 
funkcjonariusz Ministerstwa Sprawiedliwości, czy profesor prawa cywilnego Ludwik Domański ${ }^{10}$, przedwojenny adwokat, współautor znakomitego kodeksu zobowiązań - obydwaj znani raczej z komentarzy do kodeksów niż z monograficznej twórczości naukowej. Do tej grupy zaliczyć by należało profesora prawa handlowego Artura Żabickiego ${ }^{11}$, przedwojennego sędziego NTA, niegdyś wysokiego urzędnika w wiedeńskim ministerstwie skarbu, profesora prawa karnego Janusza Jamontta, profesora prawa państwowego, niegdyś jednego z twórców polskiej administracji w epoce Rady Regencyjnej, później dyplomatę i prezesa Banku Polskiego - Władysława Wróblewskiego ${ }^{12}$ lub profesora prawa cywilnego - Jana Namitkiewicza ${ }^{13}$. Wreszcie szczególne znaczenie dla przyszłości wydziału mieli młodzi naukowcy rozpoczynający tuż przed wojną karierę naukową i mogący związać się z naszą uczelnią na długo - tu trzeba wymienić profesorów historii prawa Stanisława Śreniowskiego ${ }^{14}$ i Jana Adamusa ${ }^{15}$, profesora prawa międzynarodowego Remigiusza Bierzanka ${ }^{16}$, profesora polityki społecznej i prawa pracy Wacława Szuberta ${ }^{17}$ oraz przyszłego profesora prawa cywilnego Józefa Piątowskiego ${ }^{18}$. Do tej grupy dołączyli uczeni, którzy odegrali wybitną rolę polityczną w dziedzinie nauki - profesor doktryn społecznych i ekonomicznych Adam Schaff, który na naszym wydziale rozpoczął swą długoletnią działalność w polskiej nauce oraz profesor ustroju ZSRR, Stanisław Ehrlich.

10 Sprawozdania z czynności i posiedzeń ŁTN, Łódź 1948, z. 1, s. 7; K. Baranowski, B. Baranowski, Pierwsze lata..., s. 109-111; A. Szpunar w: A. Szpunar, K. Przybyłowski, W. Siedlecki, Nauka prawa prywatnego i procesowego w Polsce, Kraków 1948, s. 11.

${ }^{11}$ L. Miastkowski, Sylwetki tódzkich uczonych, Łódź 1995, s. 102-103; A. Szpunar, K. Przybyłowski, W. Siedlecki, Nauka prawa...

12 S. Łoza, Czy wiesz kto to jest, Warszawa 1938, s. 822.

${ }^{13}$ H. Dzierzgwa, Jan Namitkiewicz (1880-1958), ZNUŁ, 1959, S. I, z. 14, s. 227-232 i Polski Słownik Biograficzny, Wrocław 1966, t. XXII, s. 503-504.

14 J. Adamus, Stanisław Śreniowski, "Czasopismo Prawno-Historyczne” 1958, R. X, z. 1, s. 251-253; B. Leśnodorski, Stanisław Śreniowski, „Kwartalnik Historyczny” 1957, t. LXIV, nr 4-5, s. 274-276.

${ }^{15}$ J. Bardach, Jan Adamus (1896-1962). Próba charakterystyki naukowej, "Czasopismo Prawno-Historyczne” 1963, z. I, s. 327-332; K. Koranyi, Jan Adamus, „,Kwartalnik Historyczny" 1963, t. LXX, s. 523-525; H. Grajewski, Jan Adamus, ZNUŁ, 1963, S. I, z. 31, s. 179-194.

${ }^{16}$ Remigiusz Bierzanek, "Sprawy Międzynarodowe” 1993, nr 4, s. 34; J. Kodrębski, Remigiusz Bierzanek, „Sprawozdania z Czynności i Posiedzeń Naukowych ŁTN” [Łódź] 1993, s. $83-87$.

${ }_{17}$ H. Lewandowski, M. Seweryński, Wactaw Szubert 1912-1994, „Państwo i Prawo” 1994, nr 2, s. 89-91. Patrz też W. Szubert, Po 35 latach, „Uniwersytet Łódzki. Materiały i Sprawozdania" [dalej MiS] 1980, nr 2 (11), s. 23-29.

18 E. Łętowska, Józef Stanisław Piątowski (1974-1986), „Państwo i Prawo” 1986, nr 11, s. 101-102; Prace z prawa cywilnego wydane dla uczczenia pracy naukowej profesora Józefa Piatowskiego, Warszawa 1985, s. 5-14. 
Powstały w ten sposób zespół ulegał w latach 1945-1950 ciągłym zmianom i - o ile wiadomo - współpraca w tym gronie nie układała się zbyt dobrze. Tym, co zbliżało wszystkich wykładowców były ogromne i trudne zadania dydaktyczne - studia na Wydziale Prawa podjęło w pierwszym roku jego istnienia ponad dwa tysiące słuchaczy, w większości na pierwszym roku. Zajęcia odbywały się w bardzo ciężkich warunkach. Wykłady rozpoczęły się w budynku Szkoły Włókienniczej przy ul. Żeromskiego, do których to pomieszczeń musieliśmy powrócić obecnie, aby sprostać dzisiejszym potrzebom wydziału. Wykłady odbywały się też w wynajmowanych na ten cel salach kinowych. Seminaria prowadzono w prywatnych mieszkaniach profesorów. W latach 1946-1948 zajęcia odbywały się w gmachu sądów na placu Dąbrowskiego i w wielu przypadkowych pomieszczeniach ${ }^{19}$. Te trudne warunki pracy niewątpliwie skonsolidowały zespół wykładowców, bardzo zróżnicowany także pod względem politycznym i ideologicznym.

W latach 1945-1948 wydział nasz nosił oficjalną nazwę Wydziału Prawno-Ekonomicznego i obejmował obok studiów prawniczych również ekonomiczne i prawno-administracyjne. W 1948 r. przyjęto nazwę Wydziału Prawa, a studia ekonomiczne zostały przeniesione do nowo powstałej Wyższej Szkoły Ekonomicznej. Studia prawno-administracyjne zostały zlikwidowane, aby powstać ponownie po kilkunastu latach i stać się trwałym elementem wydziału. Warto tu chyba wspomnieć o istnieniu w tym czasie w Łodzi wyższych studiów prawno-administracyjnych, prowadzonych w założonej przez profesora Tadeusza Hilarowicza Wyższej Szkole Nauk Administracyjnych, zwanej też Akademią Służby Publicznej ${ }^{20}$. Przyjąć można, że w roku 1949 kończy się pierwszy okres historii naszego wydziału, niewątpliwie najbardziej malowniczy i chyba najbardziej interesujący, ale też najtrudniejszy. W okresie tym program i organizacja studiów w zasadzie wzorowane były na modelu przedwojennych studiów prawniczych. Dziekanami wydziału byli uczeni starsi, z wyrobioną pozycją naukową: Borys Łapicki (1945-1946), Bolesław Wilanowski (1946-1948) i Jan Namitkiewicz (1948-1949). Reprezentowali oni tradycje uniwersytetów przedwojennych, ciesząc się niewątpliwym autorytetem tak wśród swych kolegów, jak i młodzieży.

W latach 1949-1950 następują w całym polskim szkolnictwie wyższym zasadnicze zmiany, związane $\mathrm{z}$ postępującą raptownie reformą organizacyjną i wprowadzeniem, w sposób bardzo brutalny, ideologii

19 T. Szymczak, A było to tak niedawno, MiS, 1980, nr 2 (11), s. 35; K. Kąkol, Młodość wydziału, [w:] Dwadzieścia lat Wydziału Prawa..., s. 96; W. Szubert, Po 35 latach... Patrz też J. S. Piątowski, Wydział Prawa, [w:] Materiały do dziejów Uniwersytetu Łódzkiego (1945-1950), red. B. Baranowski, K. Duda-Dziewierz, Łódź 1952, s. 99.

${ }^{20}$ K. Baranowski, Poczatki Łodzi akademickiej, Łódź 1993, s. 191-195. 
marksistowsko-leninowskiej. Wydarzenia tych lat nie doczekały się jeszcze systematycznej analizy ${ }^{21}$. Na naszym wydziale owe zmiany wiązały się z reorganizacją programu studiów (wprowadzenie studiów dwustopniowych) i bardzo istotnymi zmianami personalnymi ${ }^{22}$. Ich wyrazem było ustąpienie w roku 1949 ze stanowiska dziekana profesora Jana Namitkiewicza. Ten wybitny cywilista, sędzia Sądu Najwyższego, doświadczony prawnik praktyk, ale i autor cenionych prac naukowych, był w jakiejś mierze symbolem minionego okresu. Rozpoczynający się w roku 1949 okres reorganizacji wiązał się ze zmianami programów studiów, w których indoktrynacja polityczna zaczęła odgrywać bardzo znaczącą rolę. Wprowadzono też model studiów dwustopniowych, co wiązało się ze zmniejszeniem prestiżu wydziału, w porównaniu z Warszawą czy Krakowem. Odeszło z Wydziału na emerytury kilku starszych wykładowców, jak założyciele wydziału, profesorowie Bolesław Wilanowski ${ }^{23}$ i Artur Żabicki lub profesor prawa państwowego Władysław Wróblewski. Symbolem epoki było aresztowanie pod fałszywymi zarzutami, dotyczącymi przedwojennej działalności politycznej, profesora postępowania karnego Mieczysława Siewierskiego ${ }^{24}$.

Na wydziale pojawili się liczni profesorowie dojeżdżający z Warszawy, związani z Uniwersytetem Warszawskim lub centralnymi instytucjami prawniczymi. Byli to często uczeni wybitni, jak cywiliści Witold Czachórski czy Jerzy Jodłowski bądź karnista Jerzy Sawicki, ale ich więź z wydziałem była znikoma. Większość po paru latach zrezygnowała z zajęć w Łodzi.

W początkach lat pięćdziesiątych znaleźli też jednak na wydziale zatrudnienie ludzie, którzy związali się z nim na długo i dzięki którym stał się on tym, czym jest. Wymienić tu należy przede wszystkim młodych wykładowców przybyłych do Łodzi z Uniwersytetu Jagiellońskiego - profesora Adama Szpunara ${ }^{25}$, twórcę łódzkiej szkoły cywilistycznej, i Jerzego Wróblewskiego ${ }^{26}$, twórcę łódzkiej szkoły teorii prawa. Spośród

${ }^{21}$ P. Hübner (Polityka naukowa w Polsce w latach 1944-1953. Geneza systemu, t. I-II, Wrocław 1992) koncentruje się na problemach organizacji nauki. O problemach szkół wyższych skrótowo - t. I, s. 310 i n., 574 i n. Praca nie jest wolna od uproszczeń.

22 J. Chałasiński, Uniwersytet Łódzki...

${ }^{23}$ Profesor Wilanowski prowadził po przejściu na emeryturę zajęcia językowe ze studentami jako lektor języka rosyjskiego.

${ }^{24}$ Istotną przyczyną uwięzienia i skazania profesora Mieczysława Siewierskiego był jego opór wobec projektowanych zmian prawa karnego.

${ }_{25}$ Profesor Adam Szpunar, Sylwetki łódzkich uczonych, red. B. Lewaszkiewicz-Petrykowska, ŁTN, Łódź 1993; Studia z prawa cywilnego. Ksiega pamiatkowa dla uczczenia 50-lecia pracy naukowej prof. dr. habil. Adama Szpunara, Warszawa 1983, s. 3-14; A. Szpunar, Refleksje z okazji rocznicy, MiS, 1980, z. 2 (11), s. 20-22.

${ }^{26}$ H. Lewandowski, M. Zirk-Sadowski, Jerzy Wróblewski (1926-1990), „Państwo i Prawo” 1990, nr 10, s. 92-95; M. Zirk-Sadowski, Jerzy Wróblewski, „Nauka Polska” 1991, nr 3, s. 217-221. 
wykładowców dojeżdżających z Warszawy na długo związali się z Łodzią twórca łódzkiej szkoły prawa finansowego - Jerzy Lubowicki²7, karnista Stanisław Pławski ${ }^{28}$ i kryminolog Paweł Horoszowski. Po ustąpieniu J. Namitkiewicza ze stanowiska dziekana i krótkim okresie dziekanatu profesora Józefa Litwina, stanowisko dziekana objął w roku 1950 Adam Szpunar i potrafil przeprowadzić wydział bez zbyt wielkich strat przez chyba najtrudniejszy dla nauki polskiej okres - lata 1950-1953. Jego następcy, profesorowie Wacław Szubert (1953-1955) i Jerzy Wróblewski (1955-1956) kontynuowali jego działania. Wydaje się, że aczkolwiek w latach pięćdziesiątych liczba wykładowców i studentów naszego wydziału bardzo się zmniejszyła, to stworzył on trwałą bazę swej działalności tak pod względem osobowym, jak i lokalowym.

W roku 1948 Wydział otrzymał wreszcie, po trzech latach istnienia, własny lokal w postaci zrujnowanego gmachu pofabrycznego przy ulicy Kopernika 55. Stwarzał on niezbędne minimum dla działalności dydaktycznej. W połowie lat pięćdziesiątych ustabilizowała się kadra profesorska, a młodszymi pracownikami naukowymi zaczęli się stawać niemal wyłącznie jego absolwenci. Od roku 1956 wydział zaczyna korzystać z autonomii akademickiej. Dopiero od tego momentu można mówić o jego współodpowiedzialności za swoje losy. Warto wspomnieć, że pierwszym wybranym rektorem UŁ został Adam Szpunar.

Następne lata to dzieje cierpliwej pracy nad kształceniem polskich prawników i rozwojem polskiego prawa. Ocena ich, bez odpowiedniego dystansu, jest dość trudna. Wydaje mi się że w latach 1956-1989, stanowiących pewną całość, mimo zakłóceń politycznych roku 1968 czy okresu 1980-1982, dostrzec można przede wszystkim systematyczny, być może powolniejszy niż gdzie indziej, rozwój wydziału zarówno pod względem wartości kadry naukowej i dorobku naukowego, jak i tego, co jest podstawowym celem istnienia Wydziału Prawa, czyli liczby i poziomu absolwentów.

Poważnym wstrząsem, choć nie tak brutalnym, jak w wielu innych środowiskach akademickich, były dla naszego wydziału wydarzenia 1968 r. W tym burzliwym okresie wydział poniósł poważne straty. Odszedł z niego do Instytutu Nauk Prawnych PAN ówczesny rektor uczelni, dziekan wydziału w latach 1957-1962, wybitny i zasłużony dla wydziału cywilista, profesor Józef S. Piątowski. Wyjechali za granicę profesor prawa karnego Stanisław Pławski i profesor kryminologii Paweł Horoszowski. Z zadowoleniem można jednak stwierdzić, że z wyjątkiem jednego

${ }^{27}$ N. Gajl, Jerzy Lubowicki (1898-1964), ZNUŁ, 1965, S. I, z. 42, s. 167-171; PSB, Wrocław 1973, t. XVIII, s. 71-72.

28 S. Lelental, Stanisław Pławski 1912-1988, „Państwo i Prawo” 1989, nr 4, s. 109-111. 
z profesorów, Zygmunta Izdebskiego, który następnie dobrowolnie opuścił wydział, nie było w gronie naszej społeczności jednostek biorących czynny udział w rozpętanej przez ówczesne władze awanturze. W pewnym sensie, w dużej mierze dzięki postawie ówczesnego dziekana, profesora Wacława Szuberta, nasze środowisko uległo konsolidacji i może te, tak haniebne, wydarzenia wspominać bez poczucia wstydu. Przyczyny wspomnianych wyżej zmian personalnych leżały w zasadzie poza wydziałem.

W roku 1959 Wydział uzyskał na swą siedzibę budynek przedwojennej szkoły żeńskiej, przy ul. Składowej, dotychczas mieszczący Bibliotekę Uniwersytecka, w którym funkcjonuje do dziś. W następnych latach dobudowano do niego parterowe pomieszczenia dydaktyczne, również do dziś dnia nam służące. W 1960 r. utworzona została biblioteka wydziałowa. Pod kierunkiem kolejnych dziekanów, profesora Jerzego Wróblewskiego, profesora Wacława Szuberta, profesora Janusza Tylmana i profesor Natalii Gajl Wydział rozwijał się powoli, ale konsekwentnie. Coraz większa liczba jego wychowanków uzyskiwała doktoraty i habilitacje, zajmowała miejsca w Radzie Wydziału, wzbogacała skład ciała nauczającego.

W latach sześćdziesiątych i siedemdziesiątych ukształtowała się zachowana do dziś struktura wydziału. W zasadzie pokrywała się ona z określonymi odgórnie w całej Polsce strukturami wydziałów prawa. Można jednak mówić o pewnych ośrodkach naukowych typowych dla prawniczej Łodzi, takich jak stworzona przez Jerzego Wróblewskiego szkoła teorii prawa, przez Adama Szpunara - ośrodek cywilistyczny, przez Wacława Szuberta - szkoła prawa pracy i polityki społecznej, a przez Jerzego Lubowickiego i Natalię Gajl szkoła prawa finansowego. Burzliwe i przełomowe dla historii Polski lata osiemdziesiąte rozpoczęły się na naszym wydziale długotrwałym strajkiem studenckim w $1981 \mathrm{r} .{ }^{29}$ Studenci, kierowani przez Niezależne Zrzeszenie Studentów, poparli ogólne hasła, właściwe dla „Solidarności”, również żądania zreformowania programu studiów i przyznania młodzieży większego głosu w dotyczących jej sprawach. Pomimo burzliwych niekiedy dyskusji kadra nauczająca Wydziału opowiedziała się zdecydowanie po stronie postulatów studenckich, wśród których żądanie autonomii uczelni wyższych, z natury rzeczy bliskie nauczycielom akademickim, odegrało istotną rolę. W momencie wprowadzenia, 13 grudnia 1981 r., stanu wojennego, wydział został opanowany przez siły porządkowe, ale dzięki zimnej krwi i zdecydowaniu ówczesnego dziekana, profesor Biruty Lewaszkiewicz-Petrykowskiej (1981-1984), nie doszło do tragedii. Niektórzy pracownicy zostali na pewien czas internowani, ale wydział jako całość nie poniósł większych strat.

${ }^{29}$ R. Kowalczyk, Łódzki strajk studencki, Warszawa 1992, zwłaszcza s. 86-91. 
W roku 1989 zmiana ustroju tak politycznego, jak i społeczno-gospodarczego postawiła przed wydziałem nowe zadania, związane z transformacją społeczno-gospodarczą Polski i łączącym się z tym wzrostem roli prawa i prawników w życiu społecznym. Konkretnym wyrazem tego zjawiska był wzmożony napływ kandydatów na studia. Po długich wahaniach, idąc za przykładem innych wydziałów, rozpoczęto w 1994 r. po raz pierwszy w naszej historii przyjmowanie na studia wieczorowe chętnych bez egzaminu, ale za opłatą. Wiązało się to ze zmianą koncepcji dotychczasowych studiów zaocznych, które stały się studiami wieczorowymi. Takie rozwiązanie spowodowało dramatyczny wzrost liczby studentów wydziału, skoro na pierwszym roku studiów wieczorowych znalazło się ponad tysiąc osób. Wydział otrzymał wprawdzie do swojej dyspozycji budynek przy ul. Uniwersyteckiej 3, ale jego sytuacja lokalowa jest ciągle nadzwyczaj trudna.

Tym wyraźniej widać, że rok 1989 był dla naszego wydziału bardzo ważną cezurą i że w tym momencie rozpoczęły się zmiany jego charakteru, których efekty będą mogły być oceniane dopiero z odpowiedniego dystansu czasowego.

$[\ldots]$ 


\section{Wydział Prawa i Administracji w latach 2008-2015}

W połowie 2008 r. Wydział Prawa i Administracji Uniwersytetu Łódzkiego przeniesiony został do nowego gmachu. Jest on nowoczesny, funkcjonalny, przestrzenny i przygotowany dla studentów, którzy chcą się kształcić na jednej z najlepszych uczelni w kraju. Jego niepowtarzalny kształt zapewnił mu sławę nie tylko w Polsce, ale i w Europie. Studenci mówią o nim z dumą Paragraf.

Komfort nauki zapewniają aule i sale dydaktyczne wyposażone w sprzęt multimedialny. Nowy gmach dysponuje m.in.: dziewięcioma przestronnymi aulami, reprezentacyjną Salą Rady Wydziału, 16 mniejszymi salami dydaktycznymi, 25 salami seminaryjnymi, 87 pokojami profesorskimi, dwiema salami komputerowymi oraz salą sądowa, w której studenci podczas zajęć nabierają pierwszych praktycznych prawniczych umiejętności. W plebiscycie zorganizowanym w roku 2013 przez portal infoArchitekta.pl; "ArchiTOPTEN - Najpiękniejsze Polskie Uczelnie” Paragraf zajął pierwsze miejsce.

Nowy budynek zapewnia także doskonałe warunki lokalowe dla działalności naukowej. W ramach Wydziału działa siedem centrów naukowych: odwołujące się do ideowego i intelektualnego dziedzictwa autora O demokracji w Ameryce - Centrum Myśli Polityczno-Prawnej im. A. de Tocqueville'a, Centrum Dokumentacji i Studiów Podatkowych, Centrum Studiów Wyborczych, Center for the Theory and Philosophy of Human Rights, Centrum Ochrony Prawnej Finansów Samorządu Terytorialnego, którego celem jest udzielanie pomocy w egzekwowaniu należnych samorządom w świetle Konstytucji i ustaw ustrojowych praw do odpowiedniego finansowania ich zadań, Centrum Ochrony Danych Osobowych i Zarządzania Informacją oraz Centrum Zamówień Publicznych i Partnerstwa Publiczno-Prywatnego. Pracownicy oraz doktoranci aktywnie uczestniczą $\mathrm{w}$ realizacji projektów oraz grantów naukowo-badawczych. Ekspertyzy przygotowywane są także na zlecenie podmiotów zewnętrznych. 
Na Wydziale funkcjonuje Biblioteka im. Jerzego Wróblewskiego dysponująca bogatymi zbiorami z zakresu polskiej i zagranicznej literatury prawniczej, liczącymi aktualnie ok. 55000 woluminów książek i 4800 woluminów czasopism. Obecnie biblioteka prenumeruje blisko 200 tytułów czasopism polskich i zagranicznych, a także zapewnia studentom oraz pracownikom dostęp do baz prawniczych, takich jak m.in. Lex Omega czy Heinonline.

Kadrę naukowo-dydaktyczną Wydziału stanowią wybitni naukowcy pełniący często ważne funkcje państwowe związane $\mathrm{z}$ tworzeniem i stosowaniem prawa, m.in. ministrów, senatorów, ekspertów sejmowych, sędziów (w tym Trybunału Konstytucyjnego, Sądu Najwyższego, Naczelnego Sądu Administracyjnego), a także wykonujący zawody adwokatów, radców prawnych, prokuratorów i notariuszy. Wielu z nich to członkowie Rady Legislacyjnej oraz komisji kodyfikacyjnych, czynnie uczestniczący w pracach legislacyjnych. Pracownicy Wydziału biorą aktywny udział w międzynarodowej wymianie naukowej poprzez wygłaszanie wykładów na zagranicznych uczelniach oraz obcojęzyczne publikacje, a także udział w międzynarodowych konferencjach i towarzystwach naukowych, w których często są im powierzane prestiżowe funkcje.

Reforma szkolnictwa wyższego i wymagania nałożone przez usta-

wę Prawo o szkolnictwie wyższym stawiają przed uczelniami wiele wyzwań. Wydział Prawa i Administracji Uniwersytetu Łódzkiego, jako jeden $\mathrm{z}$ wiodących wydziałów prawa w Polsce, wprowadza rozwiązania zapewniające wysoką jakość kształcenia oraz dokonuje bieżącej weryfikacji osiagganych w tym zakresie standardów. Powołana w roku 2011 Wydziałowa Komisja ds. Jakości Kształcenia wprowadziła wewnętrzny system zapewniania jakości kształcenia. Dużą wagę przywiązujemy do ogólnego wykształcenia prawniczego, tj. kształcenia umiejętności argumentacji, logicznego myślenia i wnioskowania tak, aby studia na poziomie akademickim nie były skoncentrowane jedynie na przekazywaniu wiedzy praktycznej. Jednocześnie realizowane programy studiów oraz praktyk są na bieżąco weryfikowane i dostosowywane do potrzeb rynku. Odpowiednio w 2012 tudzież 2014 r. utworzone zostały na Wydziale Rada Pracodawców oraz Rada Biznesu. Są to podmioty, których zadaniem jest wyrażanie opinii na temat dostosowania programów studiów na Wydziale Prawa i Administracji i założonych efektów kształcenia na poszczególnych kierunkach studiów i studiach podyplomowych do potrzeb rynku pracy, a także oczekiwanych od absolwentów Wydziału kompetencji w zakresie wiedzy, umiejętności i postaw społecznych, zapewnienia studentom oraz absolwentom lepszego rozeznania w zakresie oczekiwań i wymagań rynku pracy, jak również realizacji wspólnych przedsięwzięć edukacyjnych i naukowo-badawczych. 
W skład Rady Pracodawców wchodzą przedstawiciele: Marszałka Województwa Łódzkiego, Prezydenta Miasta Łodzi, Wojewódzkiego Sądu Administracyjnego w Łodzi, Sądu Apelacyjnego w Łodzi, Prokuratury Apelacyjnej w Łodzi, Okręgowej Rady Adwokackiej w Łodzi, Okręgowej Izby Radców Prawnych w Łodzi, Izby Notarialnej w Łodzi, Izby Komorniczej w Łodzi, Regionalnej Izby Obrachunkowej w Łodzi, Samorządowego Kolegium Odwoławczego w Łodzi, Delegatury NIK w Łodzi, Komendy Wojewódzkiej Policji w Łodzi, Miejskiego Ośrodka Pomocy Społecznej w Łodzi.

W pierwszym posiedzeniu Rady Biznesu uczestniczyli przedstawiciele następujących firm: Infosys BPO Poland Sp. z o.o., Kancelaria Domański Zakrzewski Palinka sp. k., Kancelaria Fortak \& Karasiński Radcowie Prawni, KPMG Sp. z o.o., Magellan SA, PricewaterhouseCoopers Sp. z o.o. oraz Wolters Kluwer SA.

Wysoki poziom nauczania na Wydziale Prawa i Administracji Uniwersytetu Łódzkiego potwierdzają wyniki osiągane przez absolwentów podczas egzaminów na aplikacje prawnicze. Ministerstwo Sprawiedliwości od roku 2008 dokonuje podsumowania wyników egzaminów na aplikacje adwokacką, radcowską i notarialną. Pod względem zdawalności naszych absolwentów zajmujemy nieodmiennie II miejsce. W roku 2014 Wydział zajął III miejsce w organizowanym przez „Dziennik Gazetę Prawną” Rankingu Wydziałów Prawa.

Obecnie na Wydziale Prawa i Administracji kształci się ponad sześć tys. studentów na sześciu kierunkach studiów: prawo, administracja, polityka społeczna, prawo podatkowe i rachunkowość, prawo zatrudnienia - kadry i płace, prawo medyczne. Wydział dysponuje także bogatą ofertą studiów podyplomowych, m.in.: Europejskie Podyplomowe Studia Problematyki Przestępczości, Prawa Podatkowego, Prawa Pracy, Prawa Spółek, Zarządzania projektami Unii Europejskiej, Prawa Medycznego, Praw Pacjenta i Ubezpieczeń Zdrowotnych, Prawa Samorządu Terytorialnego, Prawnej Obsługi Przedsiębiorców, Prawa Wyborczego, Bezpieczeństwa i HP, Skargi Konstytucyjnej, Wniosków Organów Stanowiących Jednostek Samorządu Terytorialnego oraz Pytań Prawnych, Stanowienia Aktów Prawa Miejscowego i Aktów Administracyjnych Generalnych, Kadry i Płace, Kontrola jakości stosowania prawa przez organy samorządu terytorialnego w ramach projektu "Dobre prawo - sprawne rządzenie”, Administracja i zarządzanie dla kadry kierowniczej administracji publicznej, Ochrony Danych Osobowych, Prawa Karnego Skarbowego, Prawa Egzekucji Sądowej Prawo w przedsiębiorstwie - Studia Podyplomowe dla Przedsiębiorców i Kadry Kierowniczej Przedsiębiorstw, Prawo Podatko- 
we e-learning, Stosunki Zatrudnienia w Sferze Publicznej oraz Podyplomowe Studia Ubezpieczeń Społecznych w Zatrudnieniu.

Dzięki współpracy z uczelniami zagranicznymi na Wydziale Prawa i Administracji funkcjonują szkoły prawa obcego: Szkoła Prawa Niemieckiego (WPiA UŁ i Uniwersytet Wilhelma w Münster), Szkoła Prawa Francuskiego (WPiA UŁ i Uniwersytet François-Rabelais w Tours) oraz Szkoła Prawa Amerykańskiego (WPiA UŁ i IIT Chicago Kent Collage). Studia w ramach Szkoły Prawa Francuskiego pozwalają uzyskać, jednocześnie z polskim tytułem magistra prawa, francuski państwowy dyplom studiów prawniczych (Master 2). Absolwenci Szkoły Prawa Niemieckiego, którzy posiadają jednocześnie tytuł magistra prawa, mogą na preferencyjnych warunkach odbyć studia LL.M. na Uniwersytecie w Münster. Podobnie rzecz się ma w przypadku absolwentów Szkoły Prawa Amerykańskiego. Odbywają oni takie studia na uczelni IIT Chicago Kent Collage. W ramach realizowanych programów wymiany, takich jak m.in. Erasmus+ czy Campus Europae, studenci Wydziału Prawa i Administracji UŁ mają możliwość wyjazdów na część studiów, stypendia i staże na z górą 50 uniwersytetach, a tym samym mogą odbyć częściowo studia w językach angielskim, niemieckim, francuskim, hiszpańskim, portugalskim czy włoskim.

Na Wydziale prowadzone są także, cieszące się dużym powodzeniem, 4-letnie studia doktoranckie. Wydział ma uprawnienia do nadawania stopnia naukowego doktora i doktora habilitowanego nauk prawnych w zakresie prawa.

Na WPiA UŁ działa Wydziałowe Biuro Karier, które prowadzi aktywizację zawodową studentów, pomaga w planowaniu kariery zawodowej, wyszukuje oferty pracy, zajmuje się doradztwem zawodowym. W ramach zajęć prowadzonych w Klinice Prawa studenci pod kierunkiem wykładowców mają okazję udzielać pierwszych w swojej karierze porad prawnych.

Każdego roku na Wydziale organizowanych jest około 40 konferencji bądź seminariów naukowych. Reprezentacyjne wnętrza wydziału są idealnym miejscem do organizacji spotkań z wybitnymi przedstawicielami świata nauki, polityki i biznesu. Na przestrzeni ostatnich pięciu lat gościliśmy m.in.: prof. Władysława Bartoszewskiego, prof. Krzysztofa Zanussiego, prezydenta Republiki Federalnej Niemiec Joachima Gaucka, prezydenta Republiki Czeskiej Vaclawa Klausa. W auli naszego wydziału przeprowadzona została transmisja podczas nadania doktoratu honoris causa lady Margaret Thatcher.

W roku 2014 Prezydent Rzeczypospolitej Polskiej Bronisław Komorowski posadził na skwerze przed naszym Wydziałem „Dąb Wolności”, upamiętniający 25. rocznicę wolnych wyborów w Polsce. 
Paragraf dzisiaj to nie jest paragraf opresji skierowanej przeciwko obywatelowi, to nie jest paragraf ograniczający naszą wolność tam, gdzie ona powinna być dostrzegana, doceniana i praktykowana. To jest paragraf w ramach państwa demokratycznego, który chroni większość przed błędami mniejszości, to jest paragraf, który chroni naszą wolność obywatelską i narodową

- powiedział Bronisław Komorowski wskazując ręką na gmach naszego Wydziału. 


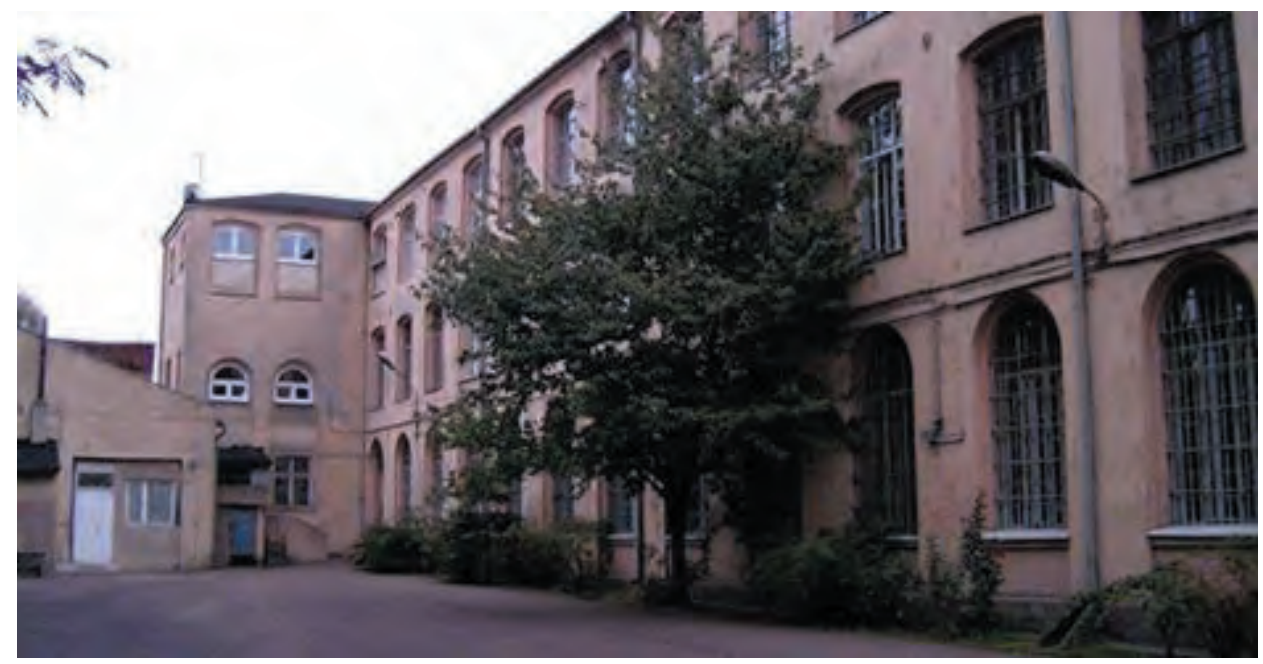

Pierwsza siedziba Wydziału Prawa, gmach przy ul. Kopernika 55, widok od strony podwórza. Fot.: Bartek Stępień (Miastograf). Archiwum UŁ.

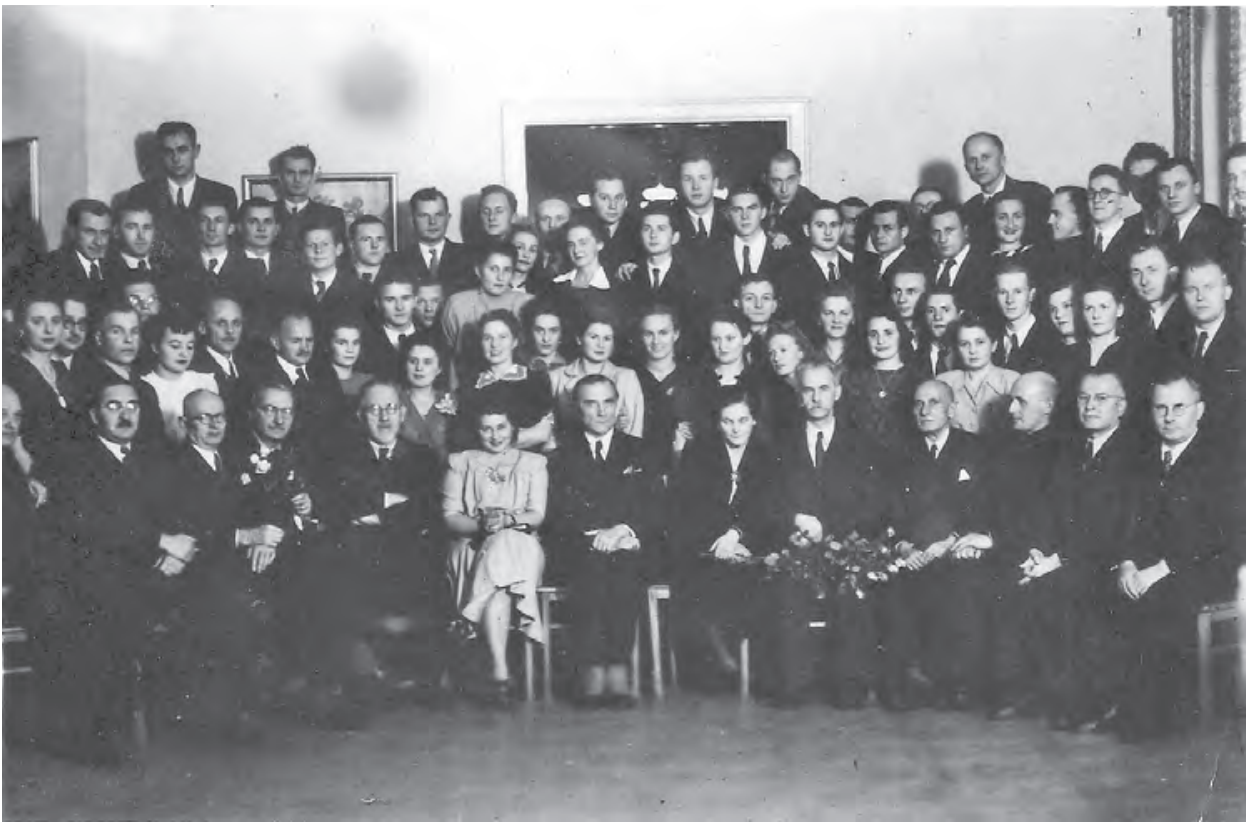

Pierwsi absolwenci i ich profesorowie (z rektorem UŁ prof. Tadeuszem Kotarbińskim) ówczesnego Wydziału Prawno-Ekonomicznego. W centrum prof. Borys Łapicki, listopad 1948 r. Zdjęcie pochodzi z osobistych zbiorów prof. Antoniego Rajkiewicza Archiwum UŁ 


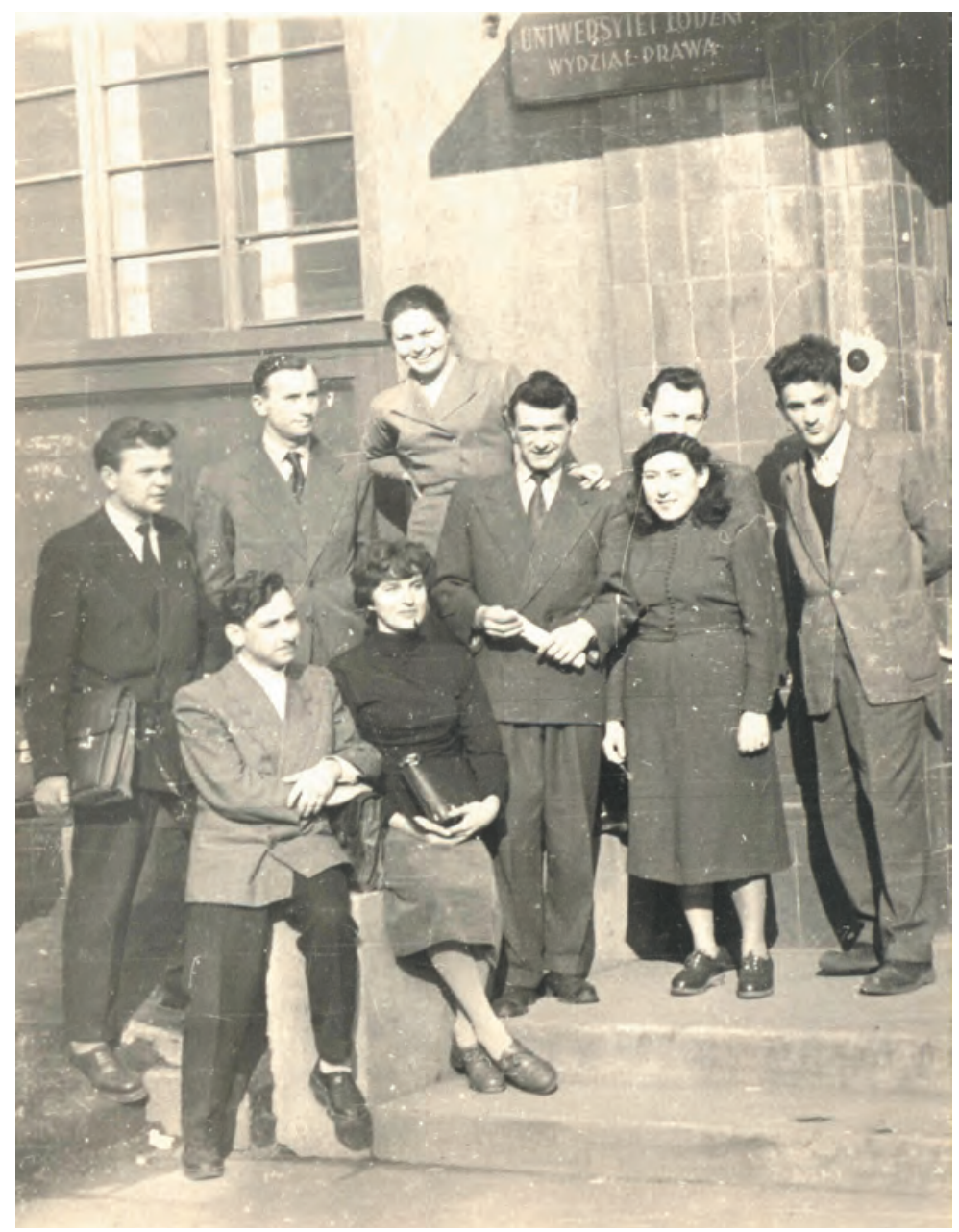

Profesor Witold Broniewicz (górny rząd w środku) ze studentami przed budynkiem Wydziału Prawa na ul. Kopernika 55, rok 1958 Zdjęcie pochodzi z osobistych zbiorów prof. Witolda Broniewicza Archiwum UŁ 


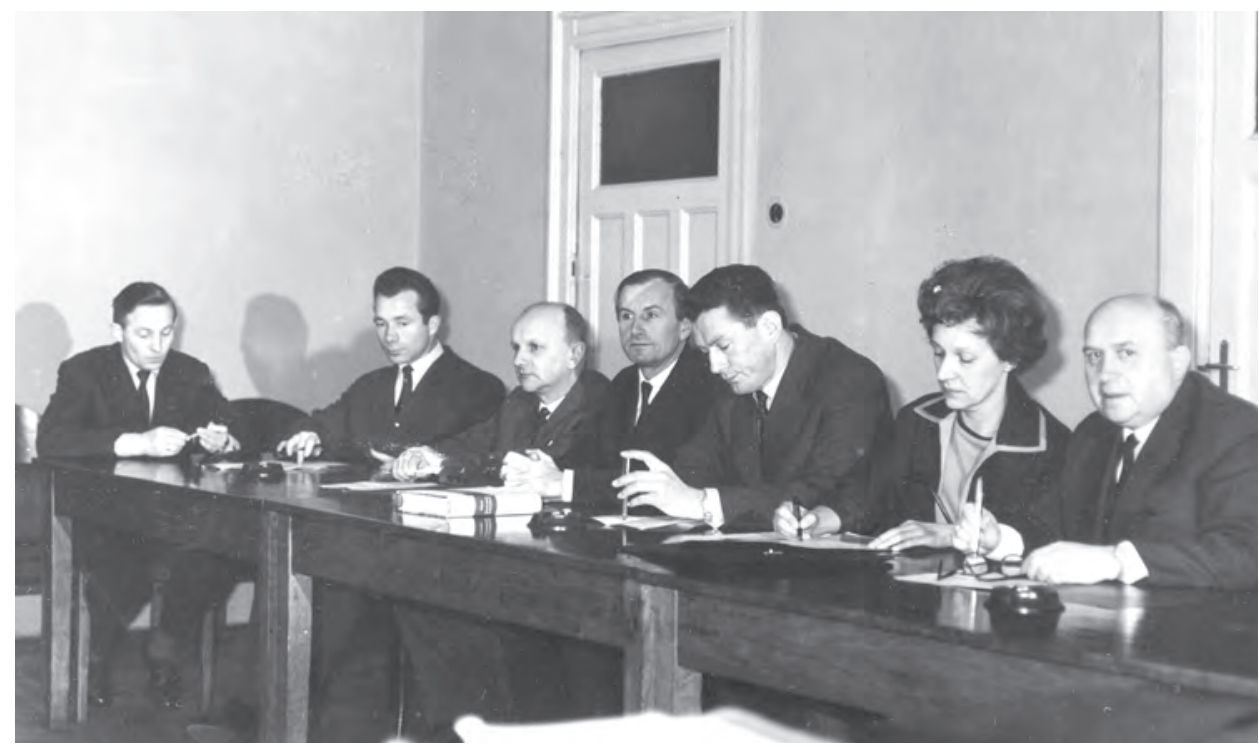

Posiedzenie Rady Wydziału, od lewej: prof. Zygfryd Rymaszewski, prof. Henryk Lewandowski, prof. Cezary Kunderewicz, prof. Witold Broniewicz, prof. Jan Waszczyński, prof. Natalia Gajl, prof. Stanisław Pławski. Zdjęcie pochodzi z osobistych zbiorów prof. Witolda Broniewicza. Archiwum UŁ

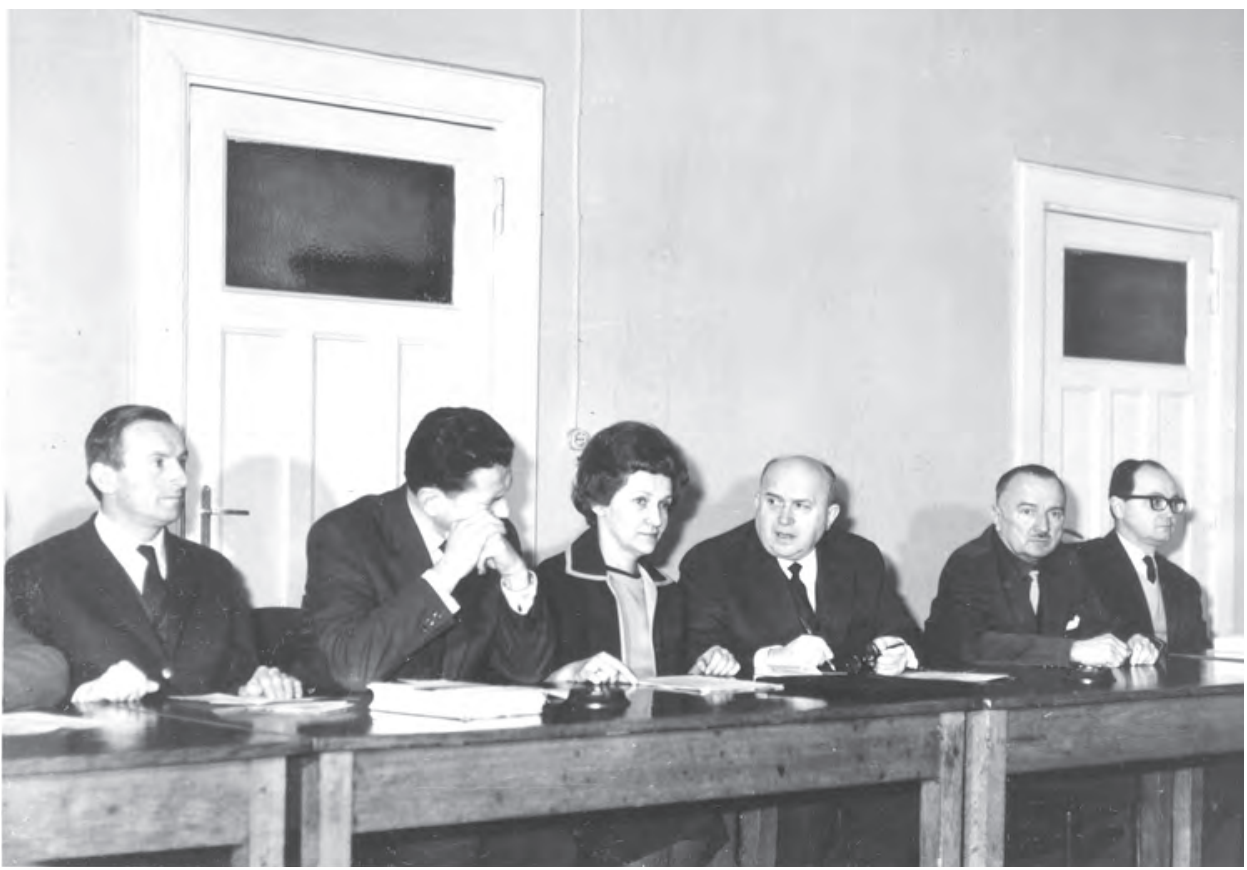

Od lewej: prof. Witold Broniewicz, prof. Jan Waszczyński, prof. Natalia Gajl, prof. Stanisław Pławski, prof. Zygmunt Izdebski, prof. Tadeusz Szymczak. Zdjęcie pochodzi z osobistych zbiorów prof. Witolda Broniewicza. Archiwum UŁ 


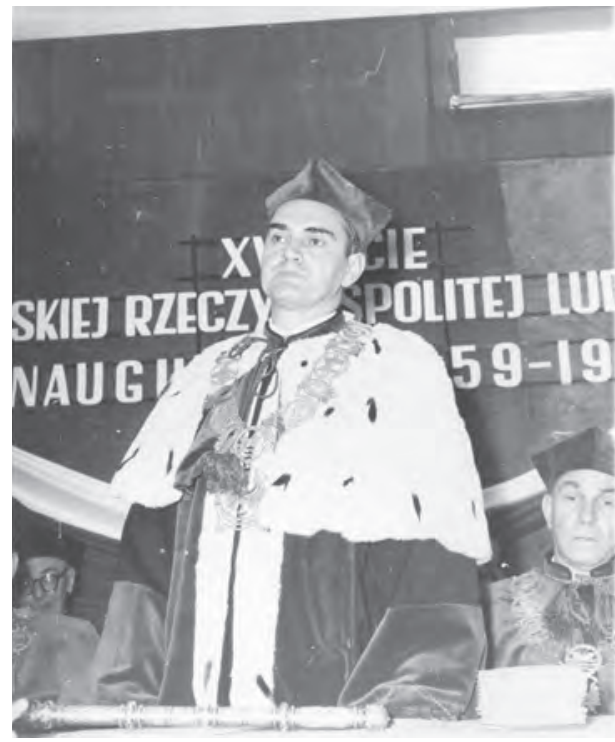

Profesor Adam Szpunar jako Rektor UŁ (inauguracja roku akademickiego 1959/1960). Archiwum UŁ

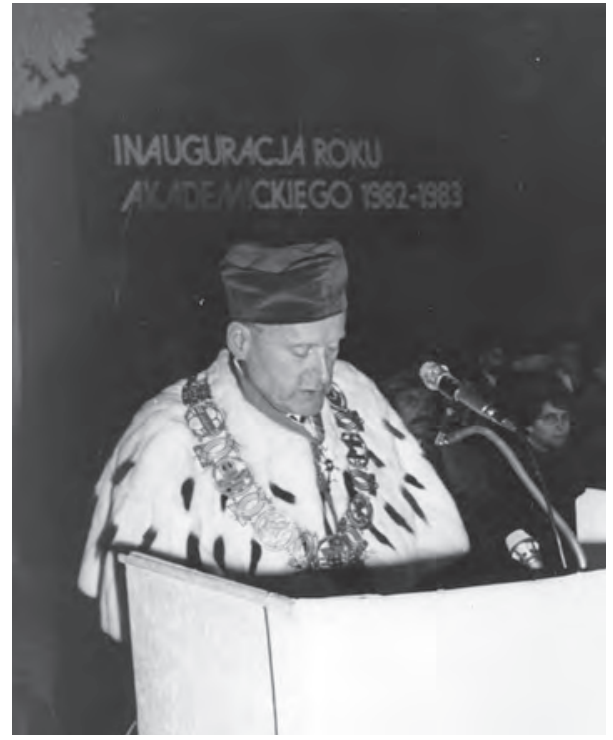

Profesor Jerzy Wróblewski jako Rektor UŁ (inauguracja roku akademickiego 1982/1983). Archiwum UŁ

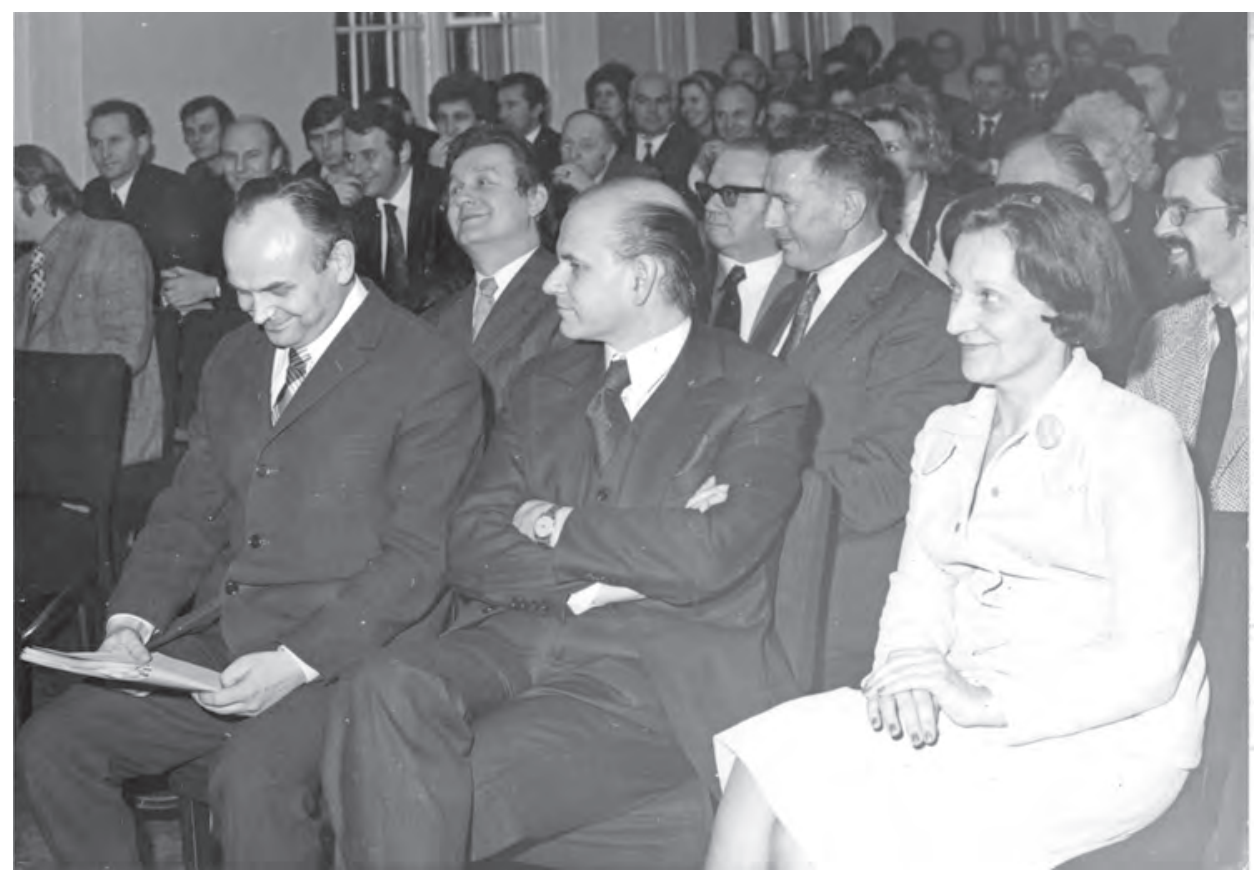

Uroczystości uniwersyteckie, pierwszy rząd od prawej - prof. Natalia Gajl, drugi rząd od prawej - prof. Stefan Lelental, prof. Jan Waszczyński, prof. Marek Olszewski Archiwum U€ 


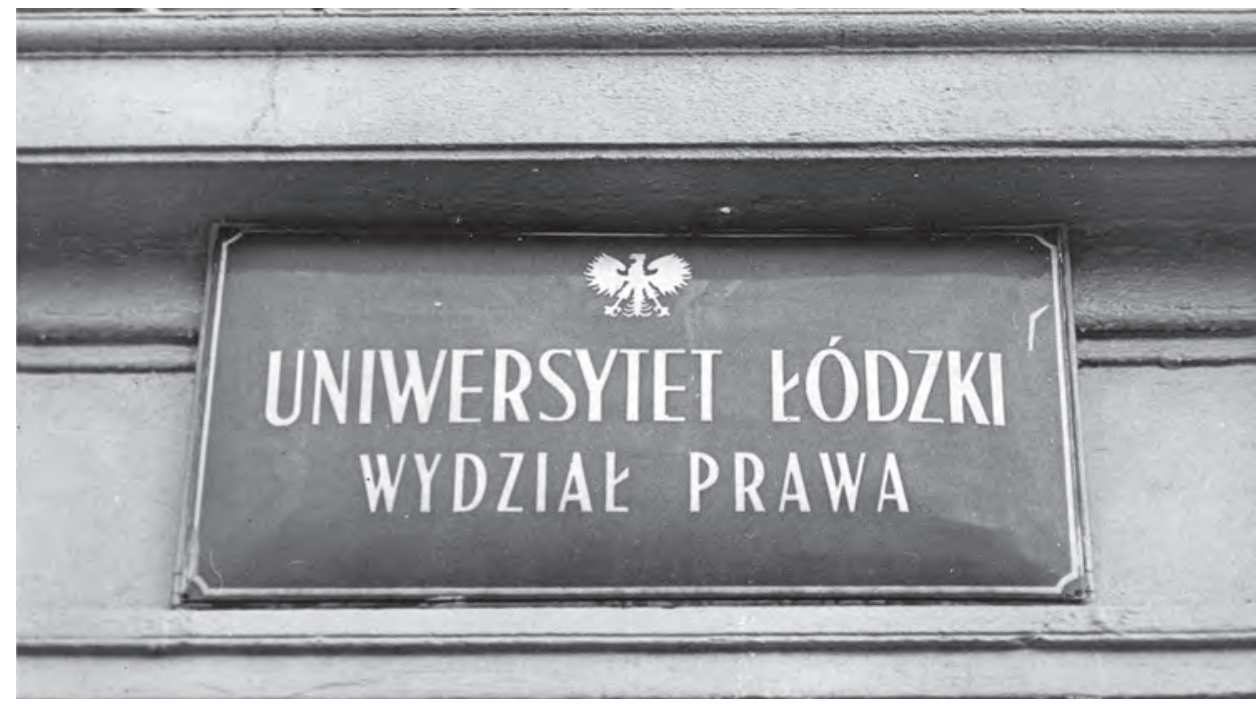

Tablica na budynku przy ul. Składowej. Archiwum UŁ

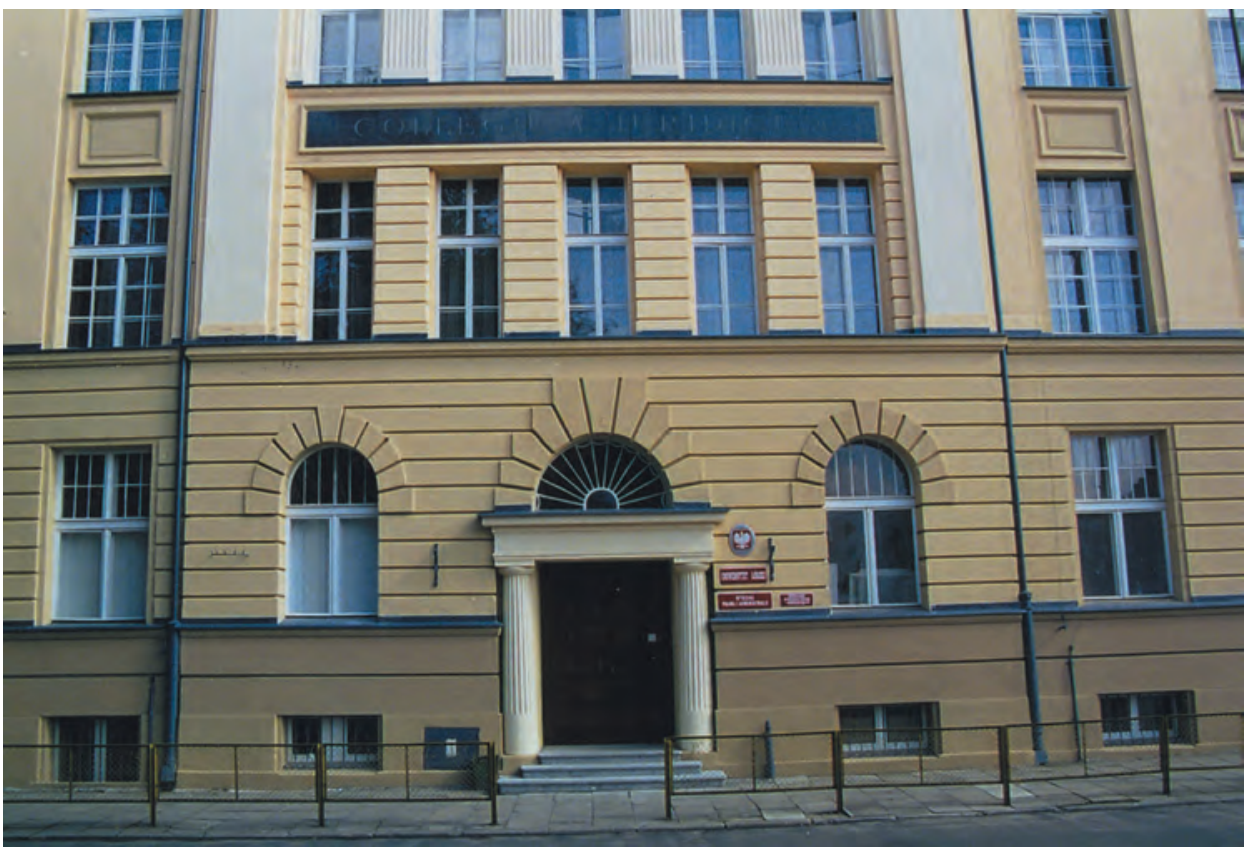

Budynek WPiA przy ul. Składowej. Archiwum WPiA 


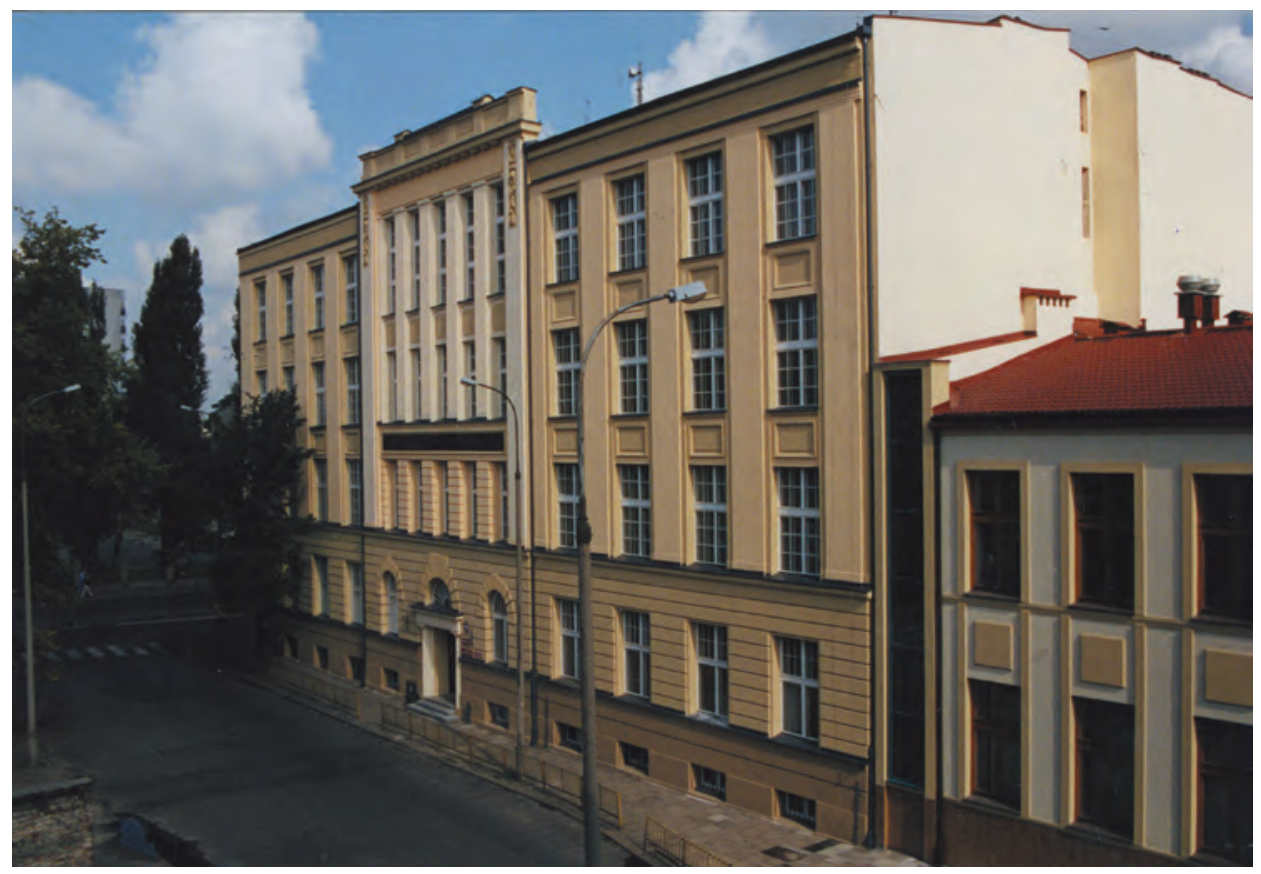

Budynek WPiA przy ul. Skladowej wraz z nowym budynkiem Dziekanatu. Archiwum WPiA

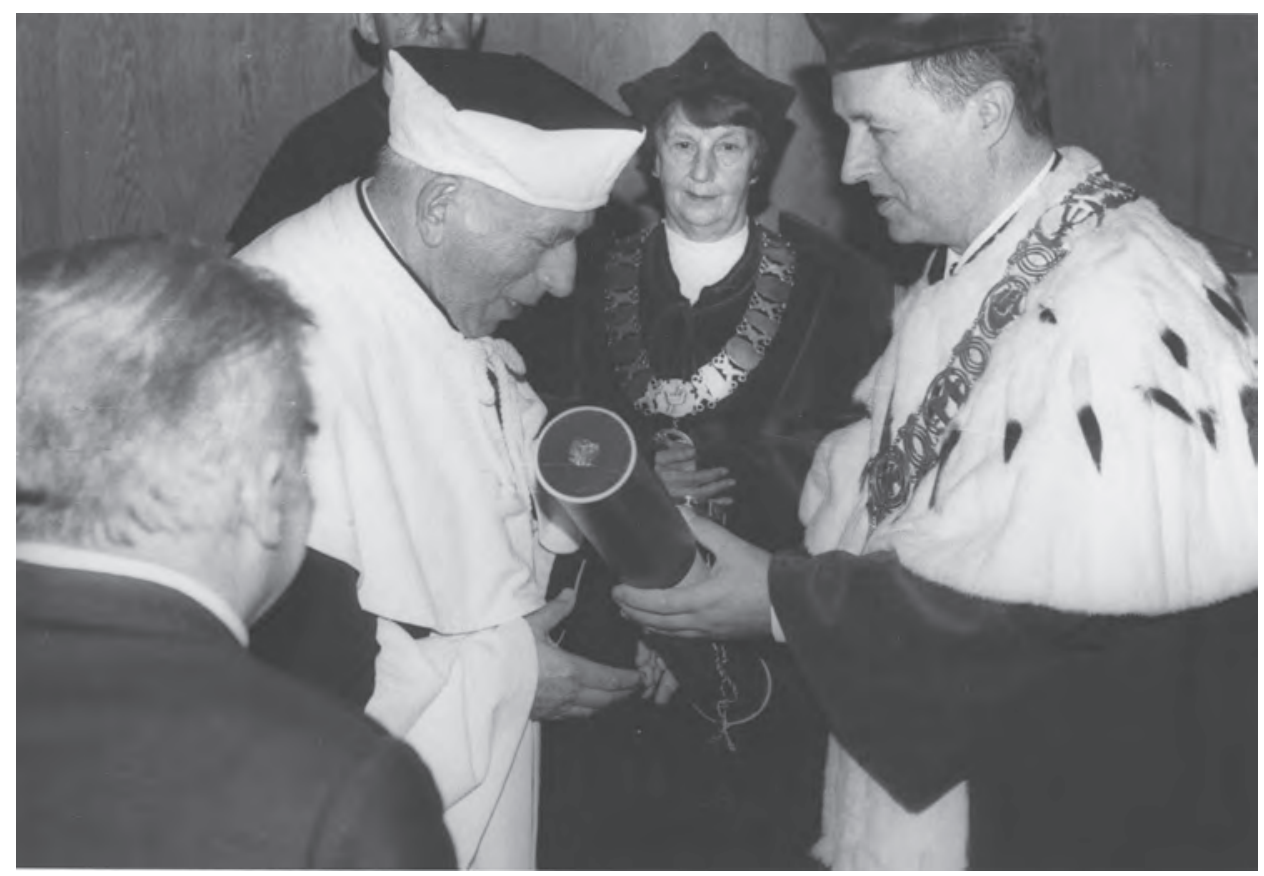

Doktorat honoris causa prof. Juliusza Bardacha. Od lewej: prof. Juliusz Bardach, prof. Biruta Lewaszkiewicz-Petrykowska (dziekan WPiA), prof. Michał Seweryński (rektor UŁ) Zdjęcie pochodzi z osobistych zbiorów prof. B. Lewaszkiewicz-Petrykowskiej 


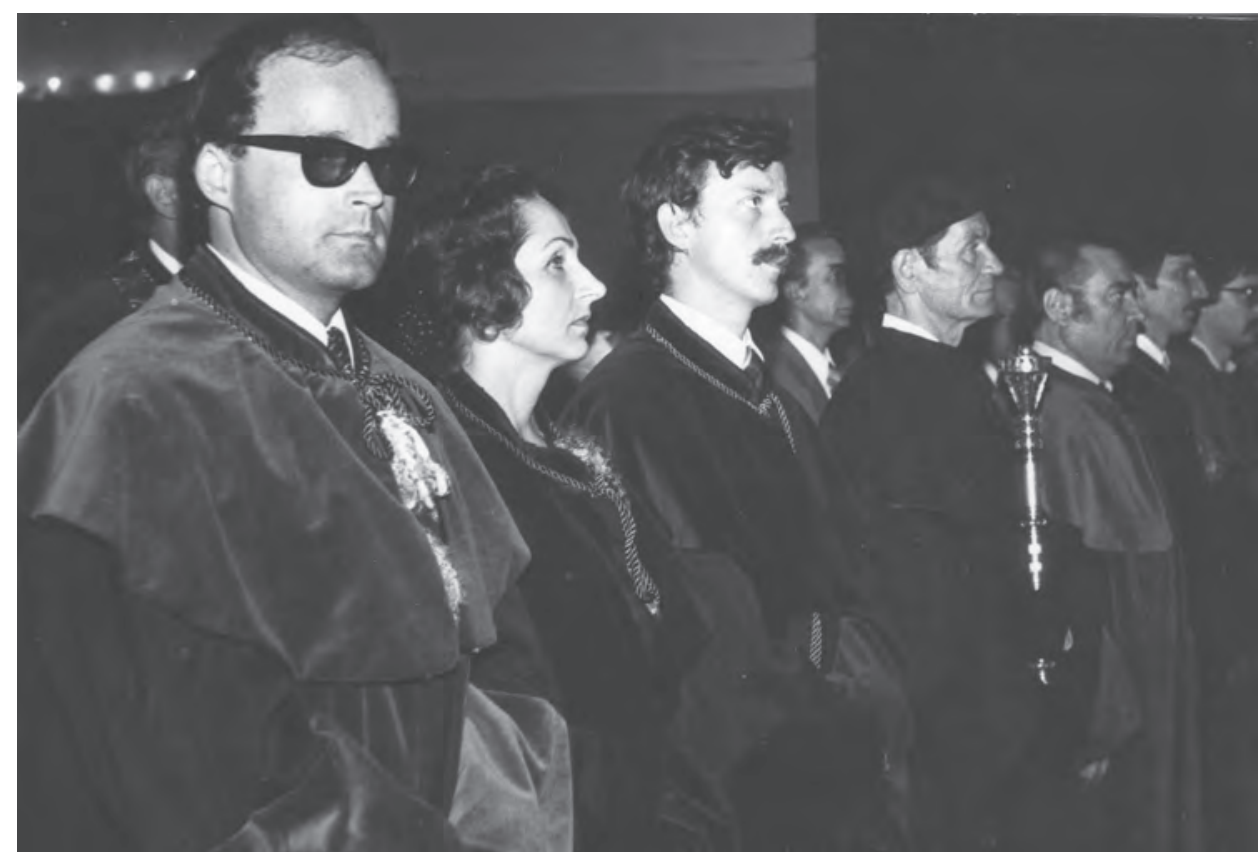

Uroczyste posiedzenie Senatu UŁ - promocje doktorskie. Od lewej: prof. Tomasz Pajor, dr Aldona Sztombka, prof. Wojciech Katner. Zdjęcie pochodzi z osobistych zbiorów prof. B. Lewaszkiewicz-Petrykowskiej

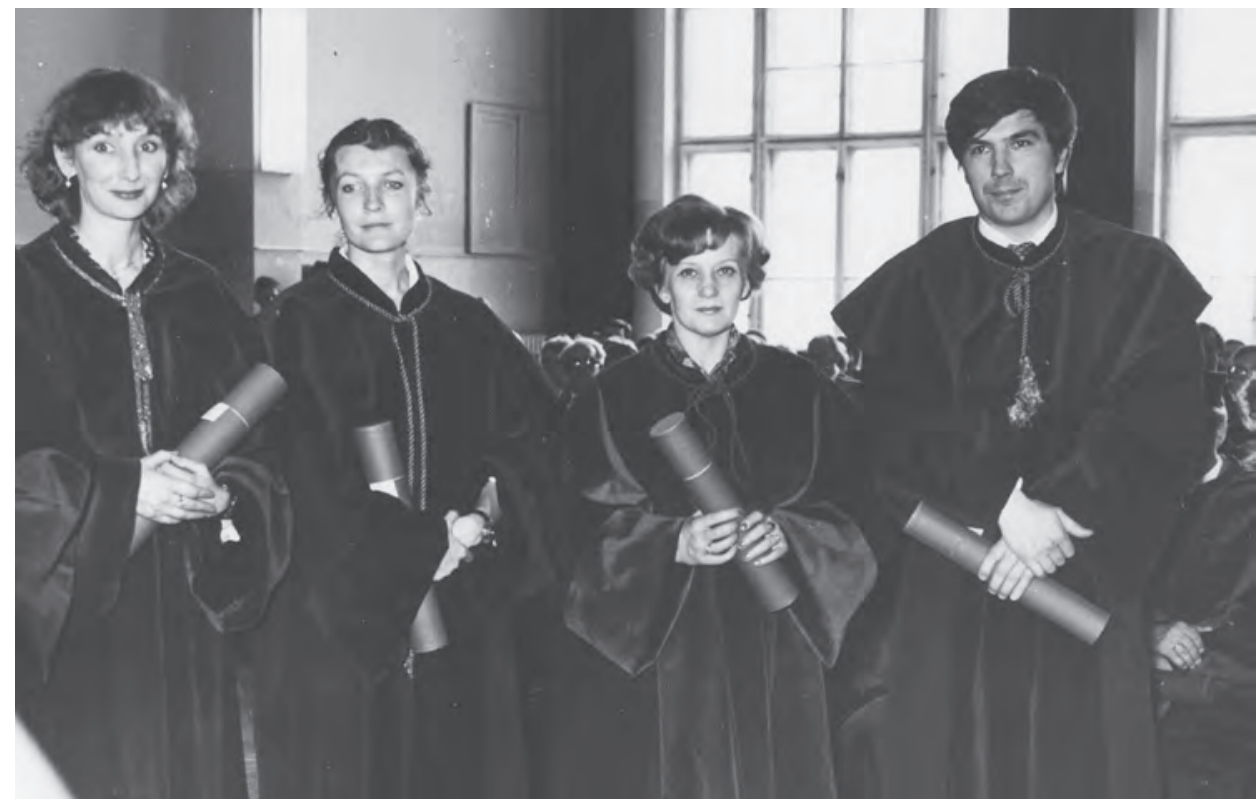

Uroczyste posiedzenie Senatu UŁ w budynku przy ul. Kościuszki 65 - promocje doktorskie, maj 1981 r. Od lewej: dr Halina Maliszewska, prof. Barbara Jaworska-Dębska, dr Zuzanna Herka, dr Witold Brodziński. Zdjęcie pochodzi z osobistych zbiorów prof. B. Lewaszkiewicz-Petrykowskiej 


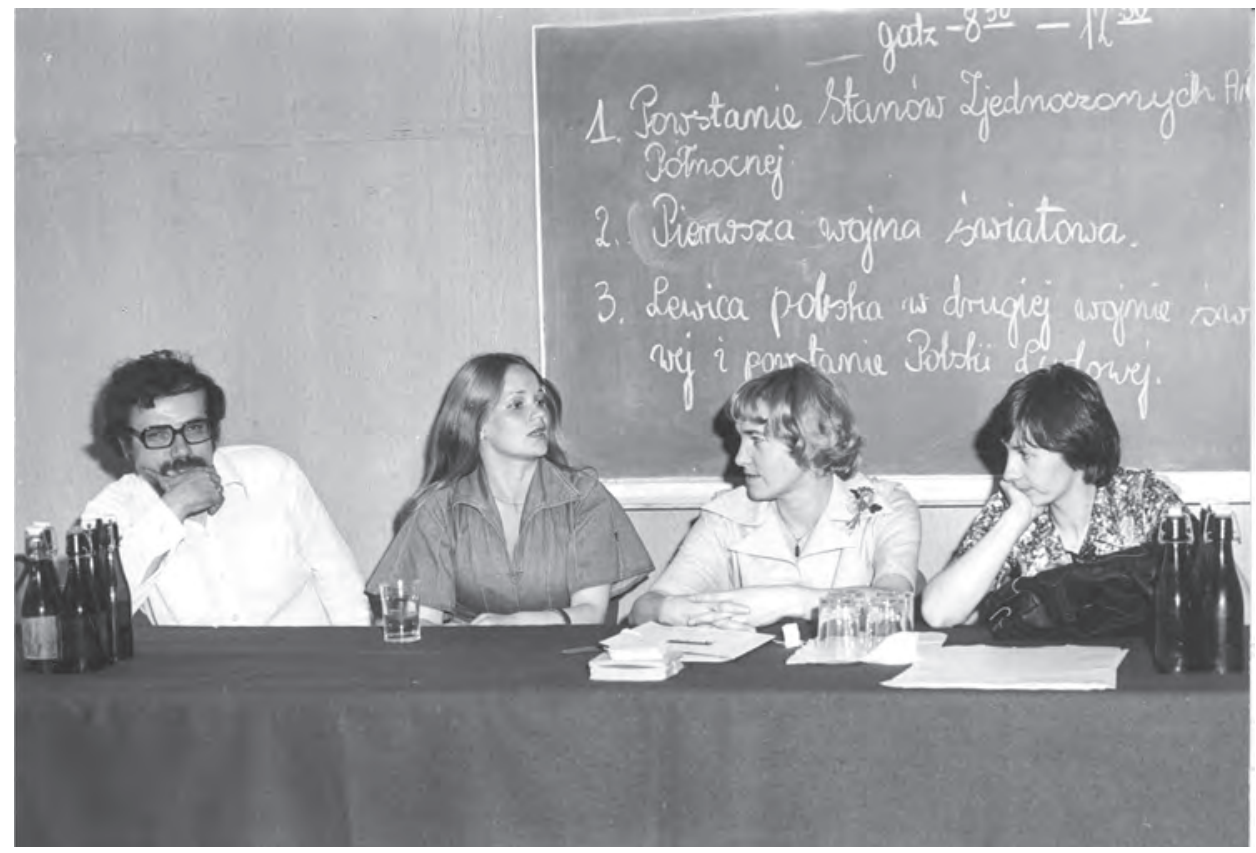

Komisja przeprowadzająca egzamin wstępny (prawdopodobnie 1982 r.), od lewej prof. Michał Kasiński, dr Ewa Kulesza, prof. Małgorzata Stahl oraz prof. Urszula Promińska Archiwum U€

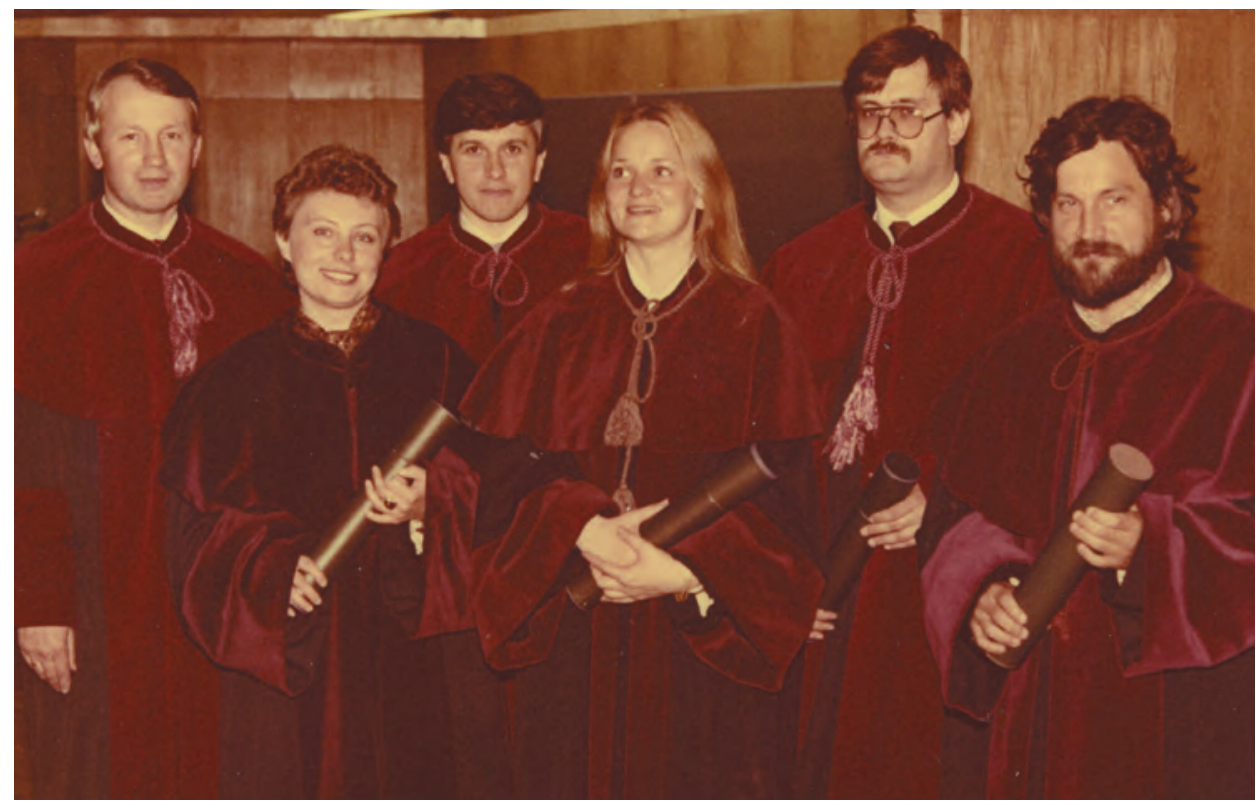

Uroczyste posiedzenie Senatu - promocje doktorskie, maj 1984. Od lewej: prof. Ewa Olejniczak-Szałowska, dr Zbigniew Świderski, dr Ewa Kulesza, prof. Krzysztof Skotnicki, prof. Zbigniew Góral. Zdjęcie pochodzi z osobistych zbiorów prof. B. Lewaszkiewicz-Petrykowskiej 


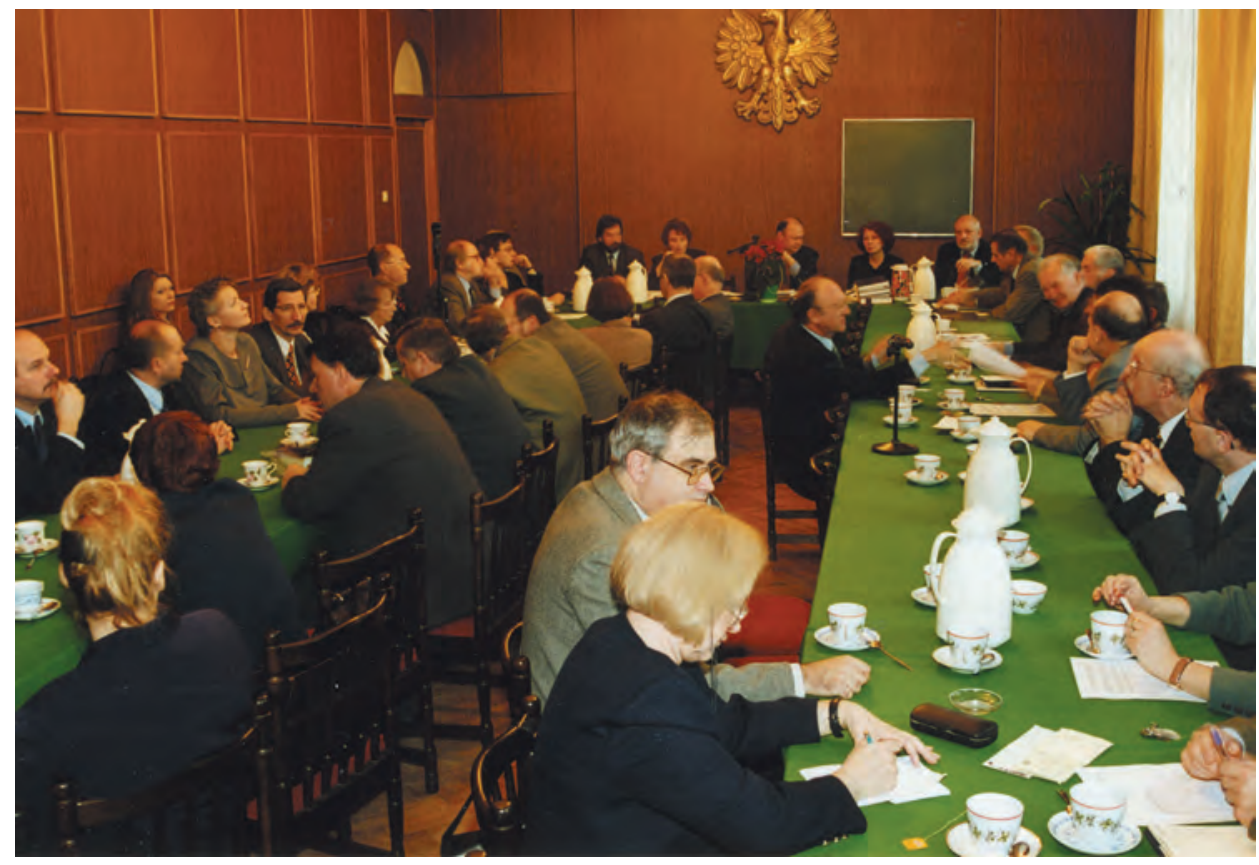

Posiedzenie Rady Wydziału w sali nr 112 (ul. Składowa). Archiwum WPiA

42

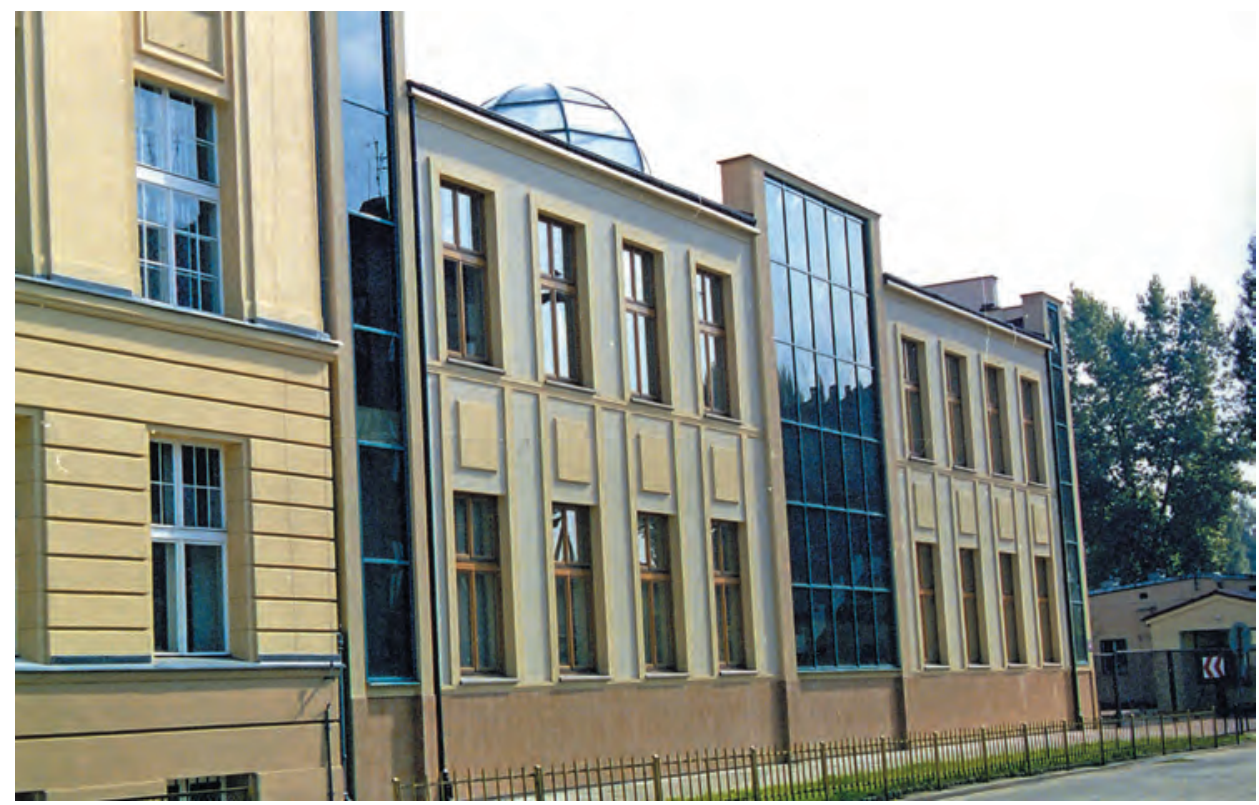

Budynek Dziekanatu przy ul. Składowej. Archiwum WPiA 


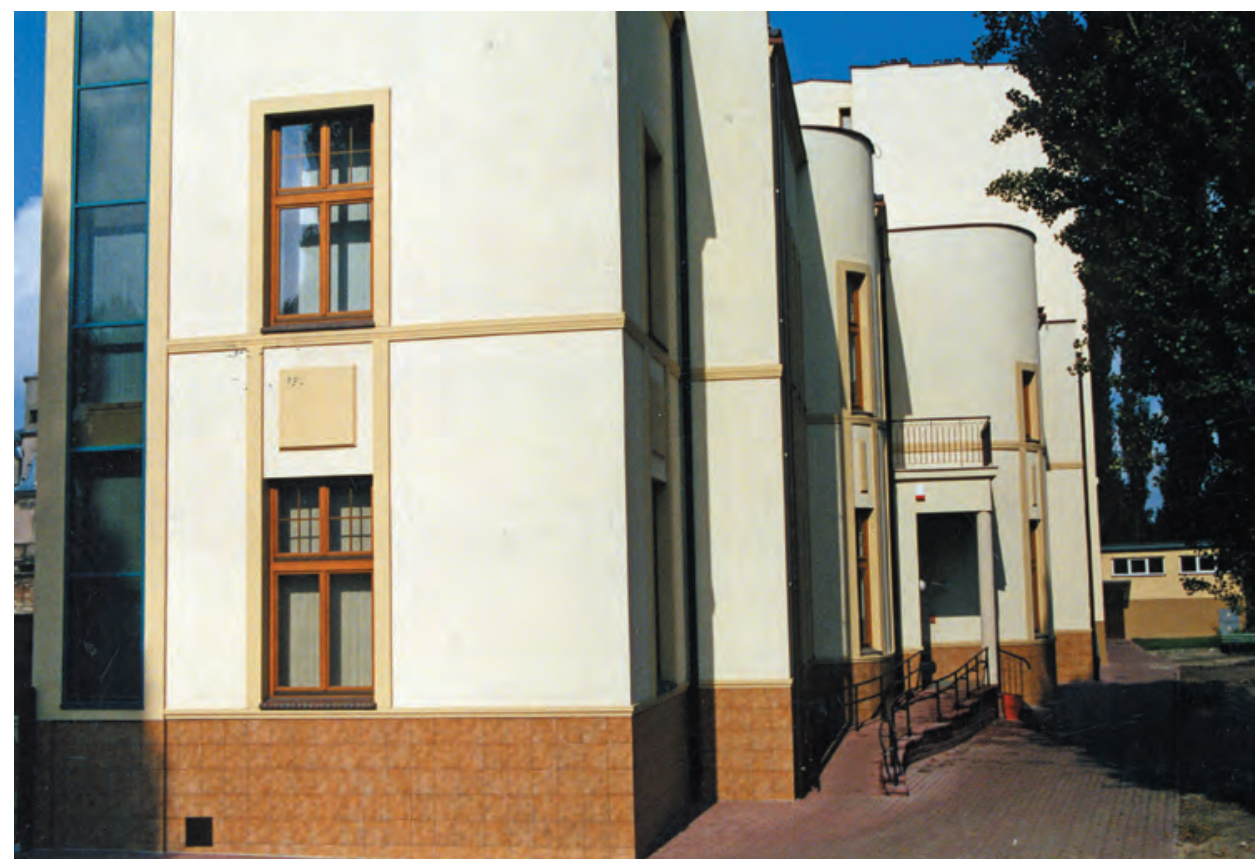

Budynek Dziekanatu przy ul. Składowej, widok od strony podwórka. Archiwum WPiA

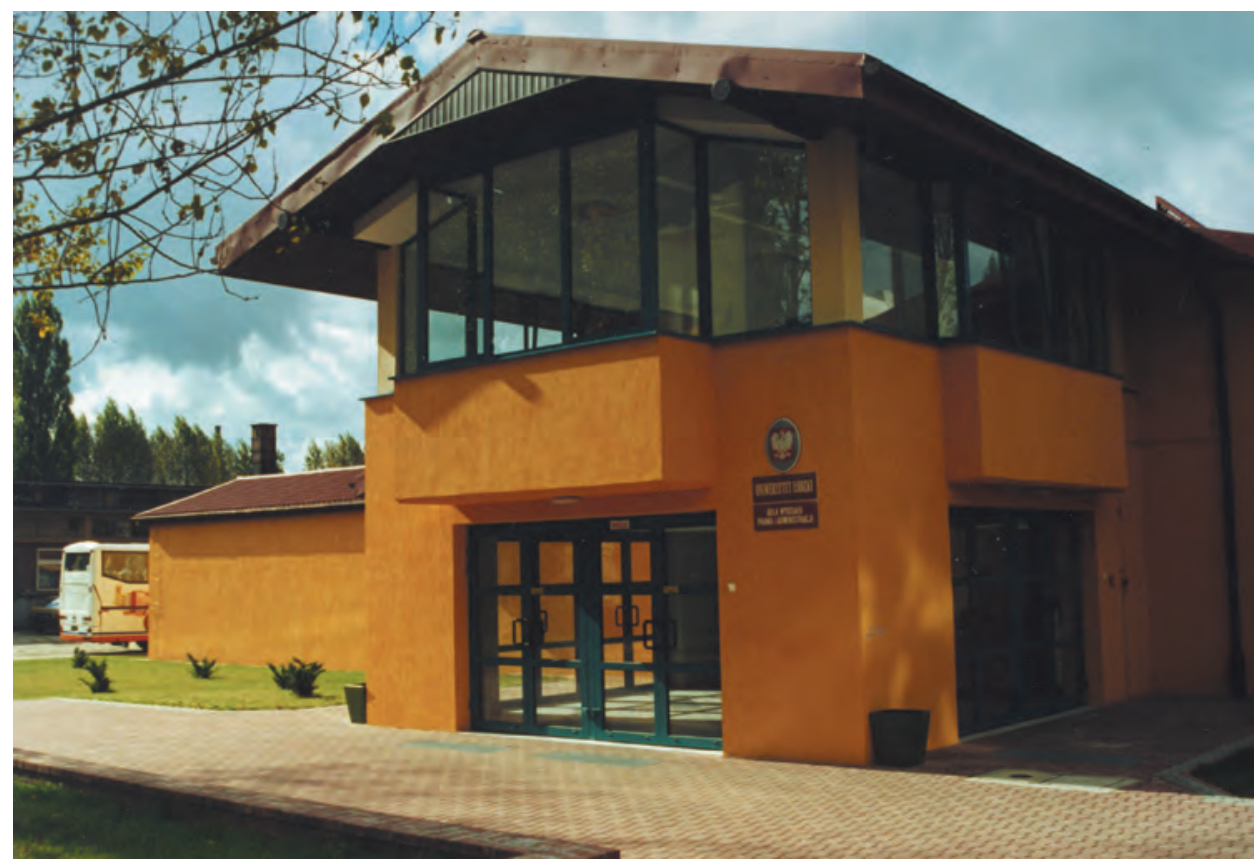

Aula WPiA im. Profesora Wacława Szuberta. Archiwum WPiA 


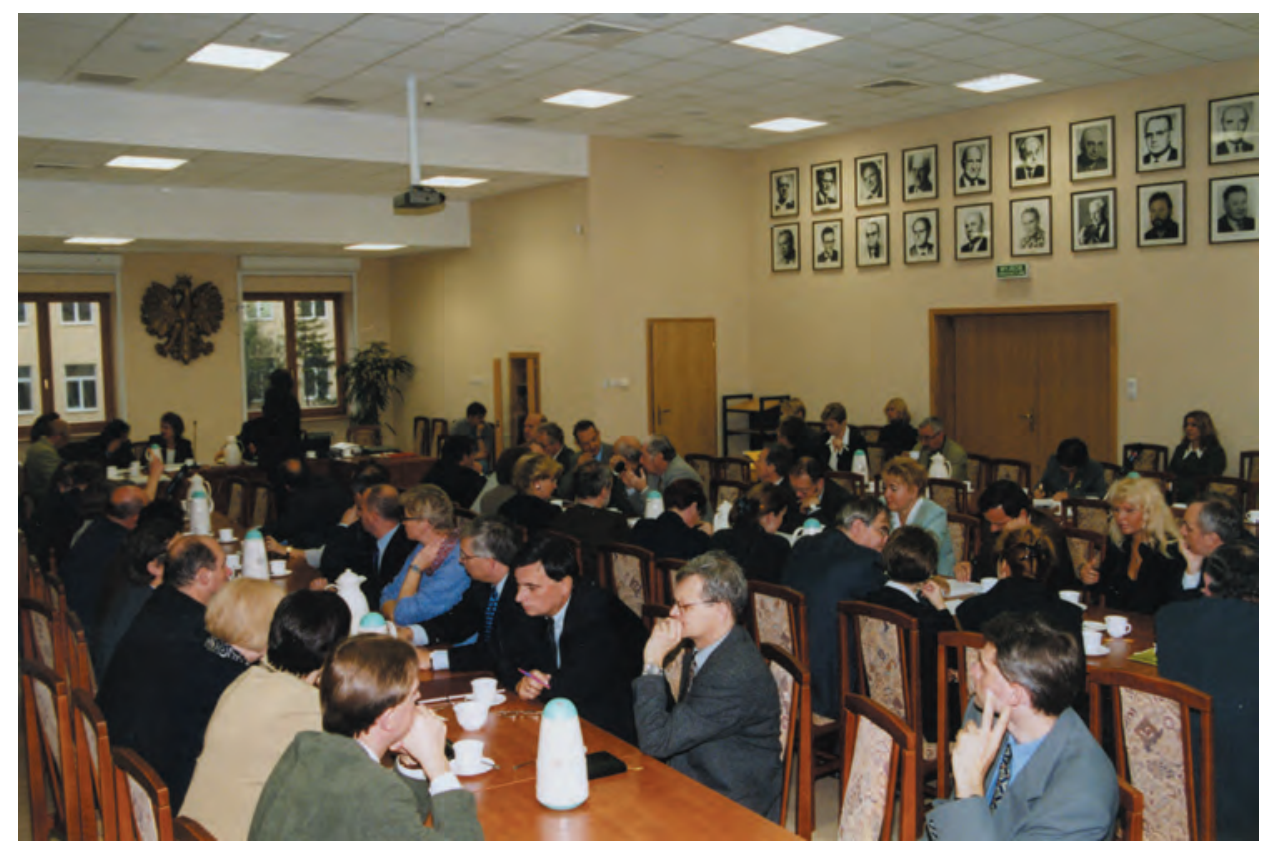

Posiedzenie Rady Wydziału w nowym budynku przy ul. Składowej. Archiwum WPiA

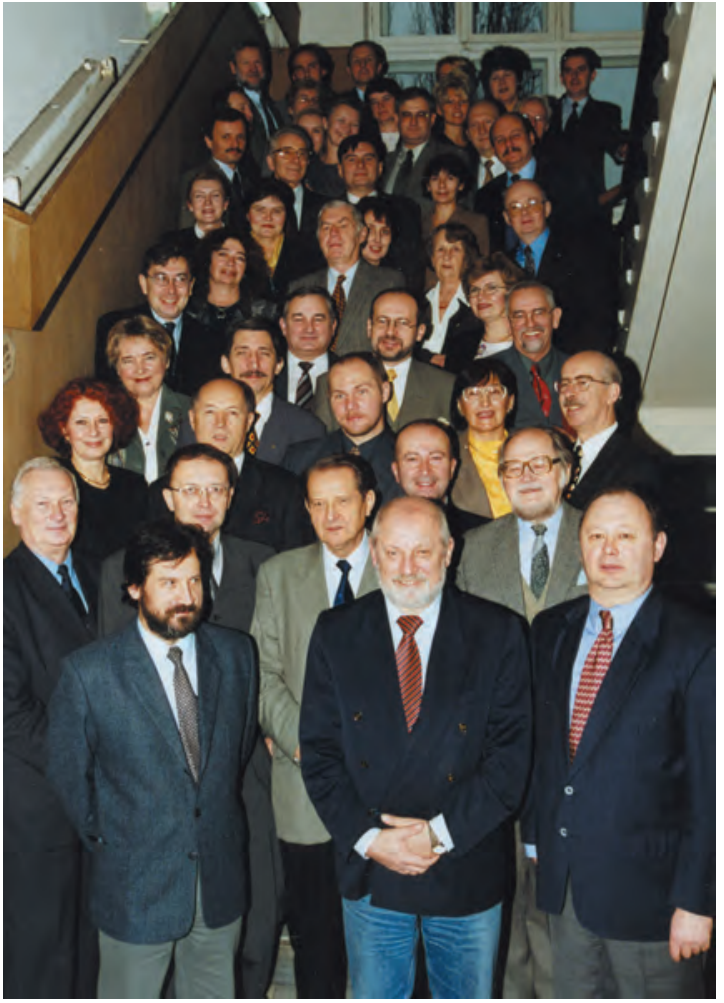

Zdjęcie Rady Wydziału na schodach w budynku przy ul. Składowej Archiwum WPiA 


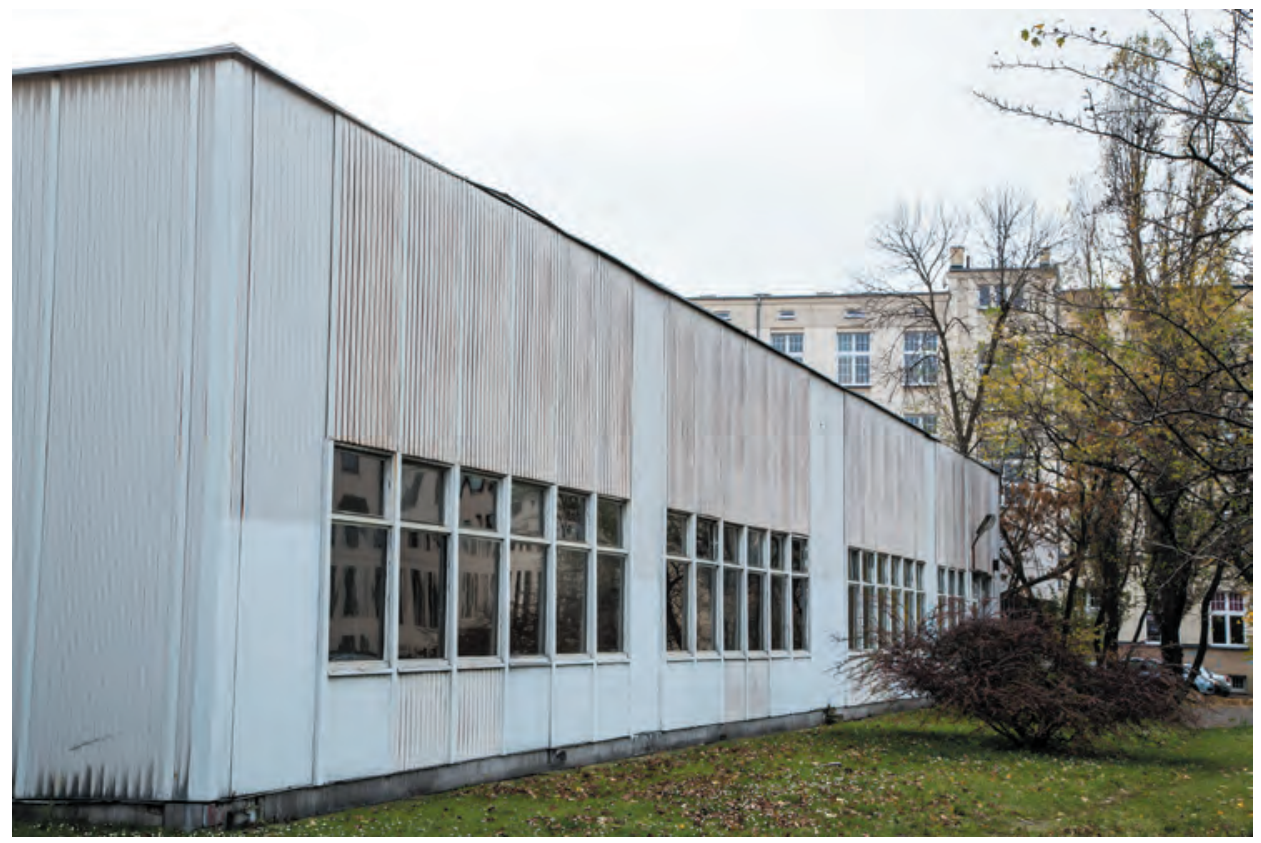

Tak zwany łącznik. Centrum Promocji UŁ

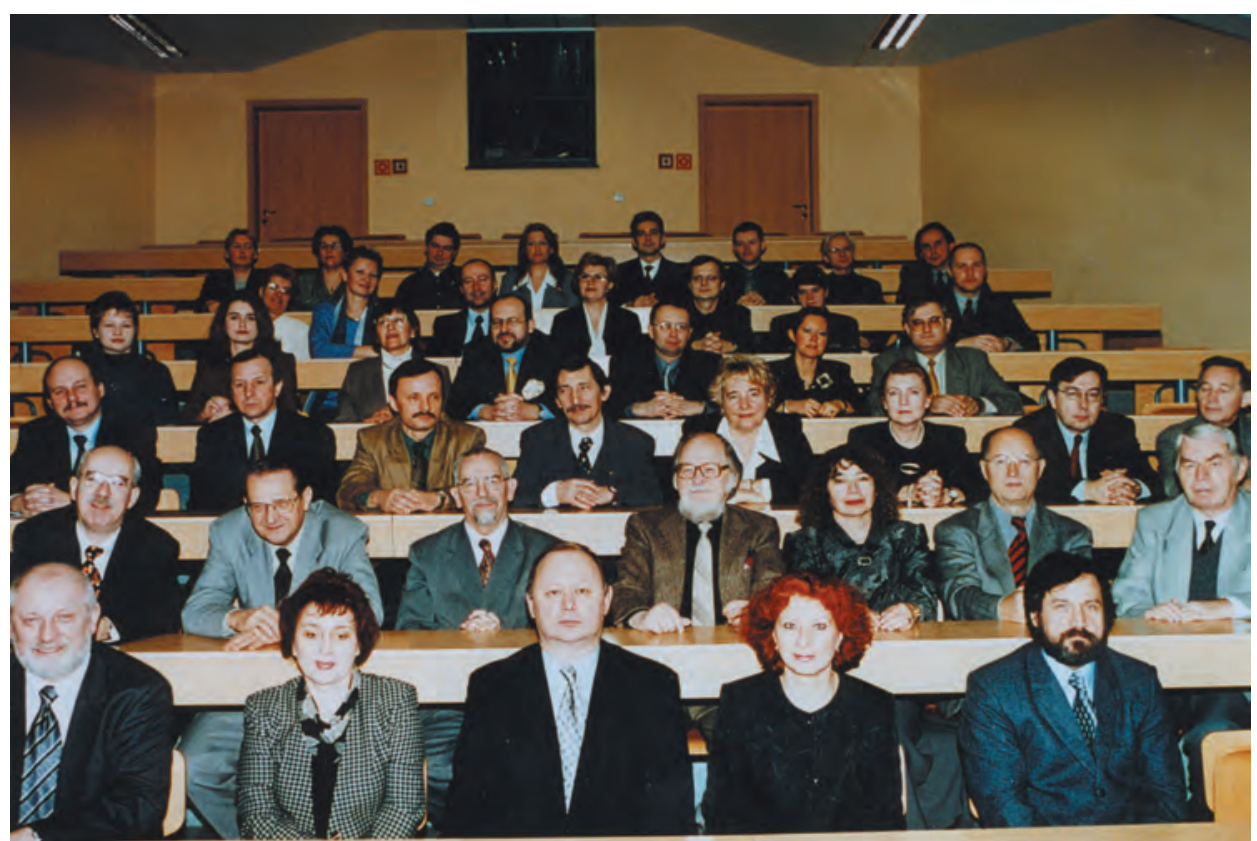

Rada Wydziału - zdjęcie w auli im. Profesora Wacława Szuberta. Archiwum WPiA 



\section{II}

Nasi Mistrzowie 



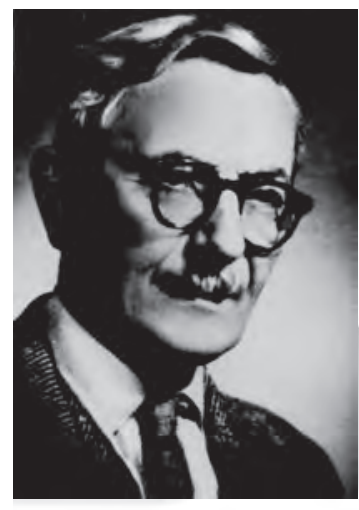

Jacek Matuszewski

Jan Adamus (1896-1962) ${ }^{1}$

テ nakomity historyk prawa, nie tylko mediewista, a także, a może $\checkmark$ przede wszystkim, doskonały, bardzo krytyczny znawca nowożytnej historiografii ${ }^{2}$. Profesor Jan Adamus to postać o skomplikowanej biografii - nie tylko tej naukowej ${ }^{3}$. Urodzony 12 marca 1896 r. w Krakowie, syn nauczyciela, był postacią nieprzeciętną a jego osobowość - także naukowa kształtowana była na trudnej drodze życiowej. Należał do pokolenia, któremu przyszło przeżyć dwie wojny światowe, a każdy z tych kataklizmów w istotny sposób wpłynął na jego drogężyciową. W czasie pierwszej łączyć musiał studia uniwersyteckie ze służbą wojskową. W konsekwencji jednocześnie kończył studia prawnicze na Uniwersytecie Lwowskim i kurs wyszkolenia prawników przy Szkole Podchorążych (1920 r. $\left.{ }^{4}\right)$. W czasie drugiej stracił pracę i cały rękopiśmienny dorobek, omal nie stracił życia, a przez wiele lat pozbawiony był kontaktu z najbliższymi.

Przygotowanie do działalności naukowej, po pierwszych krokach w Wiedniu (1914/1915), zdobywał studiując na Wydziale Prawa i Nauk

${ }^{1}$ Jeśli nie wskazano inaczej dane zaczerpnięto z akt osobowych Jana Adamusa w Archiwum Uniwersytetu Łódzkiego.

${ }^{2}$ Sam podkreślał, że jego dorobek tworzą publikacje i recenzje w materiach: historii polskiego prawa prywatnego i procesowego, historii ustroju Polski, historii polskiego dziejopisarstwa, historii i obowiązującego dawniej prawa wojskowego karnego.

${ }^{3}$ Zestawienie pośmiertnych biogramów Jana Adamusa sporządził w 1964 r. Henryk Grajewski, Jan Adamus, O kierunkach polskiej myśli historycznej. Wydanie pośmiertne. Z papierów po zmartym do druku przygotowat i przedmowa opatrzył Henryk Grajewski, Łódź 1964, s. 11, przyp. 8. Ponadto J. Bardach, Jan Adamus (1896-1962). Próba charakterystyki naukowej, „Czasopismo Prawno-Historyczne" [dalej: CPH], 1963, t. XV, z. 1, s. 327-332. Więcej, przede wszystkim o dorobku w materiałach z sesji naukowej zorganizowanej na UŁ (CPH, 1998 [za 1997], t. XLIX, z. 1-2, s. 163-239 - teksty J. Bardacha, A. F. Grabskiego, Z. Rymaszewskiego i W. Kautego). Zob. też J. Matuszewski, Jana Adamusa droga ku naukowemu niebytowi, czyli o usiłowaniu samobójstwa polskiej mediewistyki, „Studia z Dziejów Państwa i Prawa Polskiego" [dalej: SDPiPP] 2014, t. XVII s. 271-286.

${ }_{4} 15$ listopada 1920 r. został mianowany podporucznikiem Korpusu Sądowego. 
Politycznych na Uniwersytecie Lwowskim. Studia te zakończył egzaminami: prawno-historycznym, 4 maja 1918 r., z wynikiem dobrym, składanym przed znakomitą komisją której przewodniczył Oswald Balzer, a członkami jej byli Władysław Abraham, Marceli Chlamtacz i Przemysław Dąbkowski - tuzy lwowskiej historii prawa. Kolejny nastąpił 26 stycznia 1920 r. - był to egzamin sądowy, natomiast 16 września 1920 r. ostatni, zamykający studia prawnicze - z nauk politycznych. Z przyczyn prozaicznych, kłopotów materialnych, pozostawał w służbie w organach wojskowego wymiaru sprawiedliwości, kolejno we Lwowie i w Krakowie, aż do końca lutego 1930, kiedy to na własną prośbę przeszedł jako kapitan w stan spoczynku ${ }^{5}$. Wcześniej podjął pracę naukową na Uniwersytecie we Lwowie, gdzie od $1924 \mathrm{r}$. pracował jako starszy asystent w Katedrze Historii Prawa Polskiego. W 1925 r. ogłosił pracę doktorską poświęconą dziejom prawa zastawu na Litwie, na podstawie której w 1927 r. uzyskał doktorat. We Lwowie też bezskutecznie przystępował do kolokwium, ale ostatecznie (1933 r.) podjął pracę na uniwersytecie w Wilnie, gdzie w tymże roku habilitował się z historii prawa polskiego i litewskiego. We wrześniu 1939 r. niezmobilizowany, do lipca 1940 r. kontynuował pracę badawcza, przerwaną aresztowaniem. Więziony jako oficer polski, choć bez zarzutów, ostatecznie wywieziony został do Kazachstanu, gdzie cudem uniknął śmierci. Dzięki układowi polsko-radzieckiemu, we wrześniu 1941 r. mógł wstąpić do Polskich Sił Zbrojnych w ZSRR. Przydzielony do sądu polowego 6. Dywizji, zbyt niepokorny w orzekaniu, po ewakuacji do Iraku przeniesiony został w stan nieczynny (wrzesień 1942 r.), by ostatecznie objąć funkcję kierownika Archiwum Armii Polskiej w organizacji z siedzibą w Jerozolimie. Odtąd, także w czasie pobytu w Anglii, funkcjonować będzie na rozmaitych szczeblach wojskowej administracji. W końcu dostał się do Szkocji, gdzie nadal pełniąc rozmaite funkcje administracyjne, podjął pracę naukowa, a w grudniu 1944 r. został zatrudniony na Polskim Wydziale Prawa w Uniwersytecie w Oxfordzie jako wykładowca historii prawa polskiego. Po zakończonych niepowodzeniem staraniach o sprowadzenie z Polski do Anglii żony i dwóch córek, w 1948 r. zdecydował się, po ośmioletniej rozłące $z$ rodzina, na powrót do kraju. Tu rozpoczął pracę naukową na Wydziale Prawa UŁ, początkowo jako docent w Katedrze Historii Prawa Polskiego, a od 1954 r., zweryfikowany jako profesor nad-

${ }^{5}$ Problemy materialne związane z koniecznością utrzymania rodziny wpływać będą przez całe życie na jego aktywność zawodową - wciąż musiał szukać dodatkowego zatrudnienia (m.in. zatrudniony na Uniwersytecie Stefana Batorego, był też kierownikiem Archiwum Miejskiego w Wilnie, jednocześnie będąc nauczycielem w Wileńskim Liceum Handlowym i Administracyjnym; po wojnie, w Łodzi, pracował na Wydziale Prawa UŁ oraz w Centralnej Bibliotece Pedagogicznej przy Państwowej Wyższej Szkole Pedagogicznej w Łodzi). 
zwyczajny ${ }^{6}$, objął kierownictwo Katedry Powszechnej Historii Państwa i Prawa. Podejmując starania o uzyskanie tytułu profesora zwyczajnego, zastosował się „bez wahania” - jak sam pisał w liście z 16 września $1958 \mathrm{r}$. do ministra szkolnictwa wyższego - „do zasady wyrażonej przez ustawę, iż do uzyskania tytułu naukowego profesora zwyczajnego powinien się profesor nadzwyczajny poddać odpowiedniemu postępowaniu $\mathrm{w}$ celu uzyskania stopnia naukowego doktora nauk" i doktoryzował się 11 listopada 1956 r. na Wydziale Prawa Uniwersytetu Warszawskiego rozprawą O monarchii Gallowej. Po perturbacjach biurokratycznych, dzięki swym stanowczym wystąpieniom ${ }^{7}$ oraz poparciu władz Wydziału i Uczelni uzyskał w końcu decyzją CKK z 29 stycznia 1959 r. zasłużony tytuł.

Przenosiny do Łodzi przyniosły sukces wzajemny - przybyszowi i podejmującej go uczelni. Profesor uzyskał stabilizację i uznanie, chociaż jego badania wciąż przyjmowane były z pewnym dystansem. Co bardzo istotne, otrzymał też niemal nieograniczone możliwości prowadzenia badań. Uczelnia pozyskała znakomitego naukowca, człowieka prawego charakteru, uczynnego, sumiennego, dla którego celem życia pozostawała praca naukowa.

Szczupły, zawsze wyprostowany, surowy i nieco oschły, oczekujący przestrzegania należnego mu dystansu, w gruncie rzeczy dla otoczenia pełen życzliwości, której jakby bał się okazywać. Jego poglądy polityczne dla okresu wileńskiego scharakteryzował Juliusz Bardach ${ }^{8}$. Ulegały one zmianie po krytycznych doświadczeniach lat wojny i tych, związanych z pobytem w Anglii. Wybrał, choć nie miał wyboru, Polskę rzeczywista, choć nie idealną. Niekiedy miano mu to za złe, podobnie jak to, że po powrocie do kraju z pełnym przekonaniem pisał: „Marksizm rozbił formalistyczną i idealistyczną wieżę z kości słoniowej, w której nasza myśl prawnicza dawniej się zamykała" ${ }^{\prime 9}$ czy że wspominając lata emigracji nie używał superlatywów.

Unikał nadmiernego angażowania się w życie organizacyjne Uniwersytetu, nie szukał stanowisk i władzy. Ale nie brakowało go tam, gdzie rozwijała się nauka. Kilka kadencji działał w Zarządzie Łódzkiego Oddziału Polskiego Towarzystwa Historycznego, przez dziesięć lat był sekretarzem

${ }^{6}$ Na potrzeby tej procedury rektor UŁ, Jan Szczepański wystawił opinię, w której m.in. napisał: „Jestem także przekonany, że i w opanowaniu marksistowskiej metodologii doc. Adamus wyrównał swoje braki" (1 kwietnia 1954 r.).

7 J. Adamus w korespondencji z ministrem, do którego zaskarżył urzędniczą odmowę kontynuowania procedury nadania tytułu, pozwolił sobie w liście z 17 października 1958 r. na pouczenia na temat "grzeczności".

8 Jana Adamusa wspominam, CPH, 1998 [za 1997], t. XLIX, s. 167.

9 Metoda prawnicza w historii, "Zeszyty Naukowe Uniwersytetu Łódzkiego", Nauki humanistyczno-społeczne, [Łódź] 1956, s. 30. 
Wydziału II ŁTN, przygotowywał program wydawniczy łódzkiego czasopisma prawniczego, którego niestety nie udało mu się zrealizować.

Zawsze też, gdy była tego potrzeba, oddawał swój czas i umiejętności na potrzeby Wydziału. Przykładem może być zaangażowanie w rozwój katedr historyczno-prawnych. Uratował dla nauki Henryka Grajewskiego pozbawionego przez Stanisława Śreniowskiego stanowiska. Podejmował intensywne działania, by po śmierci tego ostatniego osierocona Katedra mogła samodzielnie funkcjonować. Organizował zespół do badań nad dawnym prawem sądowym, w ramach którego wynalazł i zatrudnił przyszłych profesorów, Barbarę Waldo i Zygfryda Rymaszewskiego, badań zakończonych - choć dopiero po śmierci Adamusa - znakomitymi monografiami ${ }^{10}$. Był zwierzchnikiem życzliwym, choć wymagającym, ale przede wszystkim oczekiwał od swych uczniów i współpracowników samodzielności. Podkreślał niejednokrotnie, że nadmiernie podległy mistrzowi badacz nie podejmie nowych wyzwań, nie skoryguje błędów poprzedników, brnąc co najwyżej ścieżką wydeptaną już przez swego mentora.

Sumiennie podchodził do pracy ze studentami, choć dydaktyka nie była nigdy działalnością której gotów był poświęcić się bez reszty. Najważniejszą formą aktywności była bowiem praca naukowa. Świetne przygotowanie zawodowe, znajomość funkcjonowania prawa w praktyce, nabywana w ciągu lat pracy w Korpusie Sądowym, ogromna pracowitość, pozwoliły $\mathrm{mu}$, niezależnie od trudności, na uzyskanie niesłychanie wartościowych, choć niechętnie przyjmowanych w środowisku wyników. Jego kariera zawodowa nie przebiegała gładko, awanse zarówno przed wojnąw Uniwersytecie Stefana Batorego, jak i w czasach Polski Ludowej - przychodziły z trudnością. Jego „wysokie pojmowanie roli i zadań uczonego" nie pozwalało mu szukać łatwego poklasku - wspominał Juliusz Bardach. Swe badania naukowe rozpoczynał w lwowskim środowisku międzywojnia, ale po habilitacyjnej porażce związał się na stałe z Wilnem. Tu kontynuował studia nad dawnym prawem sądowym (polskim i litewskim) ${ }^{11}$, wkraczając równocześnie w sferę badań nad dziejami ustroju. Natomiast lata naukowe spędzone $\mathrm{w}$ Łodzi stanowiły okres badań już o innym charakterze, do których przygotowywał się w czasach angielskiej emigracji. Górę w nich wzięła tendencja do podejmowania zagadnień zasadniczych. Ich konieczność wynikała, w jego mniemaniu, ze skostnienia badań zrodzonego przez uznawanie nienaruszalnej roli zakładanych przez wielkich mistrzów szkół naukowych. Sam już w początkach swej pracy prze-

${ }_{10}$ Natomiast sukcesu nie przyniosły badania Krzysztofa Szydłowskiego nad prawem bliższości na Litwie.

11 Zob. Z. Rymaszewski, Jan Adamus jako historyk prawa, CPH, 1998 [za 1997], t. XLIX, z. 1-2, s. 195-204. 
ciwstawiał się utartym poglądom, szkołom i kierunkom ${ }^{12}$. Wymagało to niesłychanej odwagi, ale też pracowitości i kompetencji. Cieniem na ocenie dorobku łódzkiego historyka po dziś kładzie się też śmiałość, z jaką przystąpił do polemiki z mistrzem, wielkim Oswaldem Balzerem. Potrafił bowiem z ostrością spojrzenia sumiennego badacza dostrzegać poważne błędy, które przytrafiały się poprzednikom i beznamiętnie wyciągać je na światło dzienne ${ }^{13}$. Do tego rozprawy Profesora Adamusa, sięgające także zagadnień teoretycznych i metodologicznych, mające prowadzić do stworzenia programu "syntezy" dziejów Polski, powstawały w niełatwym okresie pierwszych lat Polski Ludowej. Nie miało większego znaczenia to, że wysuwający je badacz przestrzegał w całej rozciągłości kanonów uprawianej nauki, że podstawowym kryterium jego badawczej aktywności było poszukiwanie prawdy naukowej. Istotniejsze było, że kwestionował wyniki, uzyskane przez poprzedników jeszcze przed odzyskaniem niepodległości czy w latach dwudziestolecia międzywojennego. A czynił to w okresie, gdy władze polityczne planowały i narzucały całkowity przewrót metodologiczny (konferencja otwocka 1950/1951), znaczna zaś część środowiska przeciwstawiała się tym próbom właśnie odwołując się i eksponując historiografię lat sprzed drugiej wojny światowej. Występowanie przeciwko dawnym mistrzom traktowane było, niezależnie od motywów, z zasady nieprzychylnie. Przy tym niechęć do rzetelnego zajęcia się wynikami pracy Adamusa mogła rodzić się także z jego pozytywnego stosunku do „lewicującego" dorobku Joachima Lelewela, a także nieskrywanej niechęci do poglądów kreowanych na gruncie nacjonalistycznych skłonności, których nie brakowało tak przed, jak i po drugiej wojnie światowej. Nieprzychylnie też mogło do niego nastawiać pojawienie się u schyłku drogi życiowej pewnej skłonności do mesjanizmu.

W końcu nie bez znaczenia pozostawał również ciężki styl, jakim posługiwał się przygotowując swe prace do druku. Niejeden z czytelników mógł mieć trudności z nadążeniem za tokiem wywodów autora, który dawał dowód, że zdaje sobie z tego sprawę pisząc:

12 „Przeciwstawienie się młodego uczonego Balzerowi znalazło wyraz w pryncypalnej krytyce teorii, która legła u podstaw koncepcji ustrojowej Balzera, jak i całej dawniejszej [...] historiografii. [...]. Przeciwko tym poglądom z całą siłą przekonania i naukowej argumentacji wystąpił J. Adamus. W szeregu prac podważał zarówno społeczną teorię rodowa, jak i teorię absolutyzmu piastowskiego. Ich ukoronowaniem była książka Polska teoria rodowa (1958), która stanowi najbardziej pełny i udokumentowany w naszej literaturze wywód obalający hipotezy, które tak długo dominowały w nauce", J. Bardach, Jan Adamus (1896-1962)..., s. 328.

13 „Na jedną cechę, znamienną dla tego uczonego, pragnę jeszcze zwrócić uwagę: nie uznawał autorytetów i to już w początkach swojej kariery naukowej [...]. Był urodzonym polemistą" - pisze wspominając swojego mistrza, Zygfryd Rymaszewski, Jan Adamus jako historyk prawa..., s. 203-204. 
jakaś część winy tego stanu rzeczy spada na mnie, to znaczy na nie dość jasne wypowiedzenie moich myśli. Będę się starał w innej pracy wyłożyć to samo w innej formie, a nie w przyjętej [...] nader skondensowanych, jakby aforystycznych ujęć.

Nie można się więc specjalnie dziwić, że prace te po prostu pomijano nader często milczeniem ${ }^{14}$.

Ale zarazem nie wolno również zapominać, że uzyskiwane $\mathrm{w}$ tych badaniach, prowadzonych aż do końca życia, wyniki zmuszają do uznania, że Jan Adamus był burzycielem mitów naukowych, ale też twórcą - opartych na krytycznej analizie źródeł - nowych poglądów na węzłowe zagadnienia ustroju monarchii wczesnopiastowskiej oraz wnikliwym historykiem historiografii ${ }^{15}$. Mimo to, jak dotąd, nie zyskał należnego mu miejsca w historiografii. Wciąż bowiem powtarzane są obalone przez Jana Adamusa wyniki wielkich poprzedników.

${ }_{14}$ Zob. J. Matuszewski, Jana Adamusa droga ku naukowemu niebytowi..., s. 275-279.

15 J. Bardach, Jan Adamus (1896-1962)..., s. 171. 


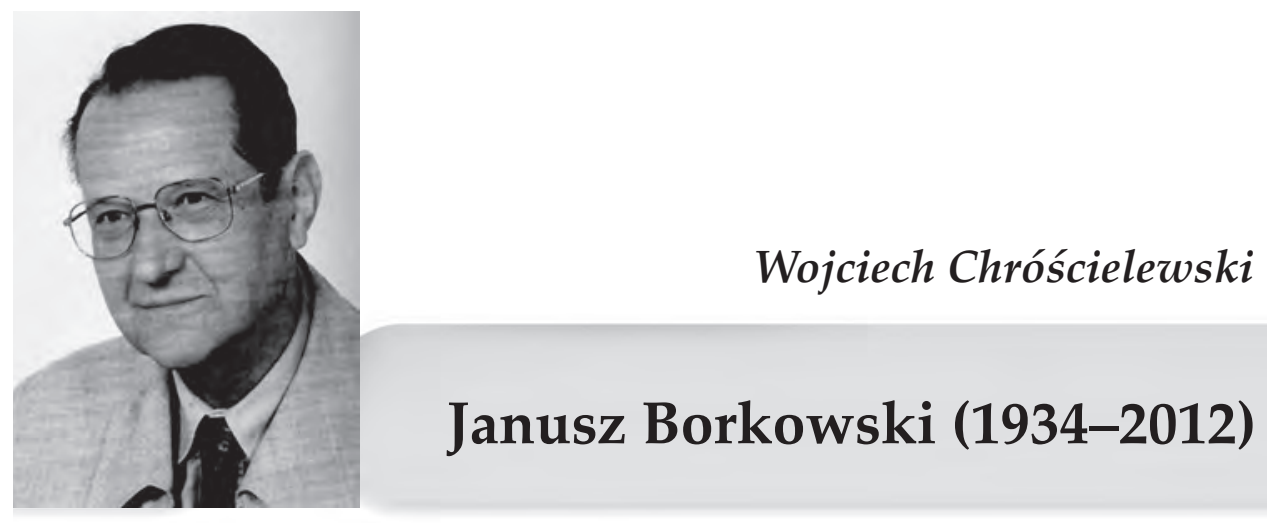

Yanusz Borkowski urodził się 7 sierpnia $1934 \mathrm{r}$. w Łodzi, gdzie w $1952 \mathrm{r}$.
uzyskał maturę w obecnym III LO i rozpoczął studia na Wydziale Prawa Uniwersytetu Łódzkiego. Ukończył je w roku 1956 i podjął pracę na stanowisku asystenta w Katedrze Prawa Administracyjnego UŁ. Na początku roku 1964 uzyskał stopień naukowy doktora nauk prawnych i został powołany na stanowisko adiunkta. W roku 1970 na Uniwersytecie Wrocławskim habilitował się, a następnie objął stanowisko docenta w Katedrze Prawa Administracyjnego UŁ. W roku 1972 objął kierownictwo zorganizowanego przez siebie Zakładu Prawa Administracyjnego Gospodarczego. Tytuł naukowy profesora nadzwyczajnego nadano mu w roku 1976, a profesora zwyczajnego - w roku 1983. W latach 1981-2002 kierował Katedrą Postępowania Administracyjnego. Do ostatnich swoich dni zajmował stanowisko profesora zwyczajnego w Katedrze Polskiego Postępowania Administracyjnego UŁ. Był doskonałym dydaktykiem, bardzo cenionym i lubianym przez studentów.

W latach 1990-1993 prof. Janusz Borkowski był sędzią Sądu Najwyższego, a następnie, po rezygnacji z tego stanowiska, aż do przejścia w stan spoczynku na początku 2000 r. - sędzią Naczelnego Sądu Administracyjnego w Ośrodku Zamiejscowym tego Sądu w Łodzi. Wielokrotnie był sprawozdawcą przy podejmowaniu uchwał powiększonych składów NSA, których tezy wywarły znaczący wpływ na linię orzecznictwa i mimo upływu lat w większości zachowują aktualność.

W języku polskim słowa, zwłaszcza w ostatnich latach, ulegają deprecjacji z powodu ich nadużywania, a także stosowania w sytuacjach zupełnie do nich nieprzystających. Nie może jednak ulegać najmniejszej wątpliwości, że w stosunku do Profesora Janusza Borkowskiego całkowicie adekwatne jest określenie „uczony”, a precyzyjniej - „wybitny uczony”. Był on bowiem niekwestionowanym, uznanym autorytetem naukowym w zakresie prawa i postępowania administracyjnego, a także sądowoadministracyjnego. 
Na jego dorobek naukowy składa się ponad 300 publikacji - monografii, komentarzy do najważniejszych ustaw z zakresu prawa administracyjnego procesowego, podręczników, studiów artykułów, recenzji i glos - w olbrzymiej większości publikowanych w najpoważniejszych wydawnictwach prawniczych i centralnych periodykach. Do dorobku tego doliczyć trzeba także ponad 200 pozycji niepublikowanych - opinii prawnych, ekspertyz, projektów legislacyjnych, recenzji wydawniczych itp. W tej niezwykle różnorodnej twórczości naukowej na szczególną uwagę zasługują dwie pozycje, które ukształtowały wiedzę i sposób spojrzenia na procedurę administracyjną rzeszy studentów, urzędników, sędziów i innych osób zajmujących się praktyką prawniczą. Są to napisane wspólnie z prof. Barbarą Adamiak, wielokrotnie wznawiane Komentarze do Kodeksu postępowania administracyjnego oraz podręczniki akademickie Polskie postepowanie administracyjne i sąowoadministracyjne, a $\mathrm{w}$ ostatnich latach Postępowanie administracyjne i sadowoadministracyjne. Każda $\mathrm{z}$ tych prac wyznaczyła trudno osiągalne $\mathrm{w}$ dziedzinie postępowania administracyjnego standardy dyskursu o prawie i technice jego stosowania, inspirując środowisko prawników administratywistów do dalszych dociekań i analiz. Prace te są powszechnie cytowane w piśmiennictwie i orzecznictwie sądowym. W wielkim stopniu przyczyniły się one do rozwoju nauki prawa i postępowania administracyjnego w Polsce. Zawierają one bowiem, zwłaszcza w odniesieniu do wspomnianych podręczników, treści daleko wykraczające poza standardowy model rozważań podręcznikowych. $W$ istocie jest to bowiem całościowa monografia polskiej procedury administracyjnej, przydatna nie tyle studentom, co naukowcom i prawnikom, a w tym - sędziom sądów administracyjnych. Bez tych dwóch fundamentalnych dzieł nauka polskiego postępowania administracyjnego $\mathrm{z}$ całą pewnością wiele by straciła. W jego dorobku na szczególną uwagę zasługują też komentarze do Kodeksu celnego i Ordynacji podatkowej, których był współautorem. Niektóre z kilkudziesięciu artykułów i studiów autorstwa J. Borkowskiego wywarły decydujący wpływ na poglądy z zakresu teorii prawa administracyjnego - zwłaszcza studia Pojęcie władztwa administracyjnego (1972) oraz Określenie administracji i prawa administracyjnego ${ }^{1}$. Znaczący wpływ na naukę postępowania administracyjnego wywarła też, zapomniana już nieco, monografia Decyzja administracyjna (Warszawa 1970). Nie sposób pominąć także jego olbrzymiego dorobku glosatorskiego odnoszącego się do orzeczeń Sądu Najwyższego i Naczelnego Sądu Administracyj-

${ }^{1}$ W: System prawa administracyjnego, t. I, Warszawa 1977. 
nego. Glosy te miały znaczący wpływ zarówno na doktrynę prawa i postępowania administracyjnego, jak i na orzecznictwo sądowe. W 2010 r. ukazał się opracowany przez niego wspólnie z B. Adamiak i A. Skoczylasem dziewiąty tom Systemu Prawa Administracyjnego - Prawo procesowe administracyjne ${ }^{2}$.

Całość dorobku naukowego prof. zw. dr. hab. Janusza Borkowskiego utwierdza w przekonaniu, że był on jednym z najwybitniejszych, o ile nie najwybitniejszym, w powojennej Polsce przedstawicielem nauki prawa i postępowania administracyjnego.

Profesor zw. dr hab. Janusz Borkowski był też mistrzem i nauczycielem dużej grupy pracowników nauki, spośród których cztery osoby kierują samodzielnymi jednostkami organizacyjnymi na Wydziale Prawa i Administracji UŁ, a dwie uzyskały już tytuł naukowy profesora nauk prawnych. Był recenzentem w kilkudziesięciu przewodach doktorskich i habilitacyjnych oraz $\mathrm{w}$ kilkunastu postępowaniach $\mathrm{w}$ sprawie nadania tytułów naukowych, a także promotorem kilkunastu przewodów doktorskich i ponad 700 prac magisterskich.

Poczynając od dokonanej w roku 1980 nowelizacji k.p.a. uczestniczył w kolejnych pracach związanych ze zmianami tego aktu oraz przekształceniami sądownictwa administracyjnego. Brał również czynny udział $\mathrm{w}$ innych pracach legislacyjnych jako członek komisji problemowych i zespołów zajmujących się przygotowaniem projektów ustaw i ekspert. Odegrał znaczącą rolę w opracowaniu w latach 2006-2008 pod auspicjami Rzecznika Praw Obywatelskich projektu ustawy Przepisy ogólne prawa administracyjnego, który niestety nie został uchwalony przez Parlament.

Profesor J. Borkowski był przez kilka kadencji członkiem Komitetu Nauk Prawnych PAN, członkiem Centralnej Komisji do Spraw Tytułu Naukowego i Stopni Naukowych oraz Państwowej Komisji Akredytacyjnej.

Był wielokrotnie nagradzany orderami i odznaczeniami państwowymi, w tym w roku 2000 Krzyżem Komandorskim Orderu Odrodzenia Polski, a w 2005 Krzyżem Komandorskim z Gwiazdą Orderu Odrodzenia Polski. Otrzymał też kilkanaście nagród, w tym rektorskich, ministerialnych (ministra kierującego działem szkolnictwo wyższe), sekretarza naukowego PAN i szefa Urzędu Rady Ministrów.

Profesor Janusz Borkowski był prawdziwym człowiekiem renesansu, posiadającym obok dogłębnej znajomości prawa, także rozległą i w dodatku wcale nie powierzchowną wiedzę z zakresu podstawowych zagadnień techniki, literatury, historii i sztuki. Miał talenty techniczne i manualne

${ }^{2}$ C. H. Beck, Instytut Nauk Prawnych PAN, Warszawa 2010. 
- często sam naprawiał zużyte czy popsute urządzenia i przedmioty - zamki do drzwi i mebli, barometry, zegarki. Należał zarazem do grona miłośników twórczości J. Haška i był wybitnym „Szwejkologiem”.

Jego wielki dorobek naukowy i orzeczniczy jest niepodważalny. Wiele generacji prawników i administratywistów będzie z niego korzystało jeszcze przez wiele lat.

Spoczął w Alei Zasłużonych cmentarza na Dołach w Łodzi³.

${ }^{3} \mathrm{~W}$ biogramie wykorzystano informacje zamieszczone $\mathrm{w}$ księdze jubileuszowej wydanej z okazji 70. rocznicy urodzin prof. zw. dr. hab. Janusza Borkowskiego - Stowo o Jubilacie, [w:] Procedura administracyjna wobec wyzwań wspótczesności, Łódź 2004. 


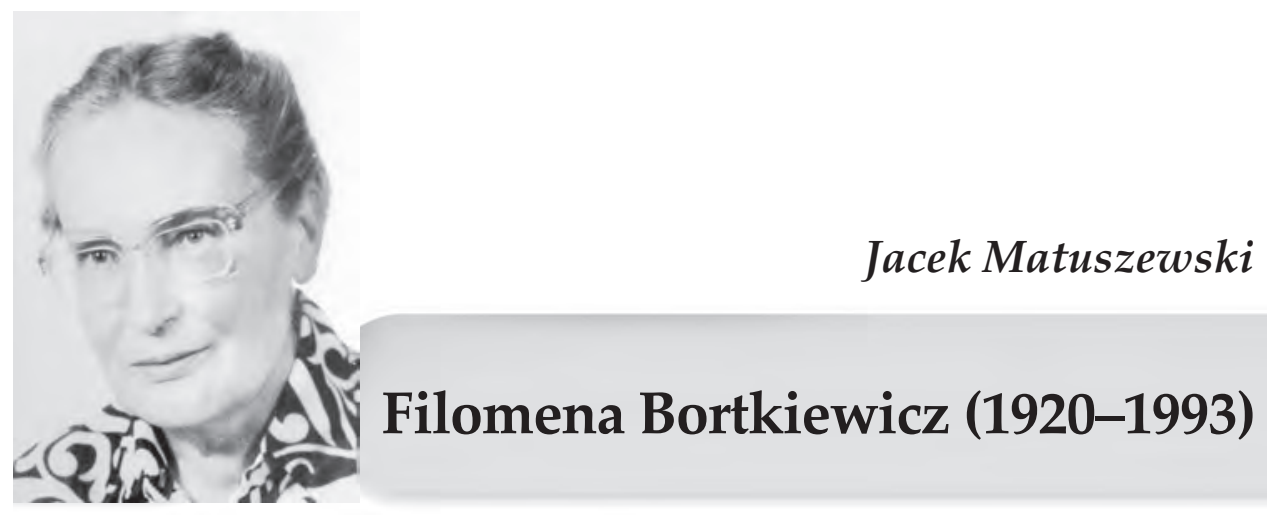

Przyszła na świat 8 grudnia w Wilnie w ubogiej rodzinie. Na domiar złego ojciec, Franciszek Wojciechowski, konduktor kolejowy, odumarł ją zanim ukończyła pierwszy rok życia. Początkowo na utrzymaniu trudniącej się pracą fizyczną matki, Pauliny ze Szwarców, od IV klasy gimnazjum już sama korepetycjami zapewniała sobie środki na koszty nauki i życia. Po uzyskaniu w 1937 r. matury typu humanistycznego w Gimnazjum Państwowym im. Adama Czartoryskiego w Wilnie, na podjęcie studiów na Wydziale Prawa Uniwersytetu im. Stefana Batorego będzie się mogła zdobyć się dopiero w roku akademickim 1938/1939. Zmuszona przerwać studia wraz z wybuchem wojny, wobec braku możliwości zatrudnienia, kontynuuje prywatne korepetycje i dorabia wykonywaniem trykotaży. W latach 1941-1944, wykorzystując zdobyte $\mathrm{w}$ trakcie udzielania prywatnych lekcji umiejętności, uczestniczy w tajnych kompletach. Po zakończeniu niemieckiej okupacji pracuje aż do 1948 r. w Wilnie, w Urzędzie Głównego Pełnomocnika Rządu RP ds. repatriacji ludności polskiej. Następnie, wraz z poślubionym w 1942 r. Stefanem Bortkiewiczem, przenosi się do Łodzi, gdzie podejmuje przerwane studia prawnicze, pracując jednocześnie jako kierownik Oddziału Interwencyjnego w Zarządzie Centralnym Państwowego Urzędu Repatriacyjnego. Magisterium uzyskuje w roku akademickim 1949/1950, ale już od maja 1950 r. zostaje młodszym asystentem w Katedrze Prawa Rzymskiego. Ze względów etatowych, w kolejnym roku (wrzesień), przeniesiona zostaje do Katedry Historii Państwa i Prawa Polskiego, z którą pozostanie związana aż do przejścia w 1990 r. na emeryturę. W nowej Katedrze znalazła się pod wpływem nieco despotycznego kierownika, Stanisława Śreniowskiego, który w tym czasie całkowicie poświęcił swoje wcześniejsze zainteresowanie naukowe modnej wówczas „chłopomanii” i takich samych za- 
miłowań badawczych wymagał od współpracowników. Zlecał jej także - o czym później wspominała z żalem - udział w pracach edytorskich poświęconych publikacji źródeł do dziejów polskiego chłopa ${ }^{1}$.

Kariera naukowa Filomeny Bortkiewicz przypadła na okres drastycznych zmian związanych z próbą wprowadzenia radzieckiego modelu rozwoju naukowca. W latach 1951-1958 awans osiągało się przez przygotowanie i opublikowanie ${ }^{2}$, zastępującej tradycyjny doktorat, pracy kandydackiej (,kryteria kwalifikacji na stopień kandydata nauk muszą być wyraźnie wyższe niż zastosowane dotychczas w znacznej większości przypadków kryteria oceny prac doktorskich (starego typu)" $)^{3}$, co przy szczęśliwym przebiegu całego postępowania zapewniało tytuł samodzielnego pracownika naukowego - docenta ${ }^{4}$. Jednak poddająca się tej procedurze F. Bortkiewicz nie zdążyła jej zakończyć przed następującym w wyniku przełomu roku 1956 powrotem do starych zasad ${ }^{5}$. Przy tym w lipcu 1957 r. zmarł nieoczekiwanie jej promotor. Z tego powodu wydrukowana już (czy raczej dopiero) w 1958 r. rozprawa kandydacka (Nadziały i powinności chłopów w dobrach prywatnych Królestwa Polskiego), poddana została publicznej obronie dopiero 22 stycznia 1960 r. i przyniosła jedynie stopień naukowy doktora ${ }^{6}$.

Wraz z objęciem Katedry Historii Państwa i Prawa Polskiego kuratelą Jana Adamusa, a następnie przejęciem jej kierownictwa przez Henryka Grajewskiego, z zakresu poszukiwań naukowych Katedry zniknęły nadal modne kwestie związane z historią chłopów polskich w XIX i XX w. Pod wpływem Adamusa także F. Bortkiewicz zajęła się problematyką ściśle prawną, przygotowując się kolejnymi publikacjami z zakresu praktyki funkcjonowania sądów wiejskich w państwie

${ }^{1}$ Powstanie Styczniowe: materiały i dokumenty, t. IV, Chłopi i sprawa chłopska w powstaniu styczniowym: materiały z terenu guberni radomskiej, Wrocław 1962 (wyd. przy współpracy S. Kieniewicza i I. I. Kostiuszko).

$2 \S 12$ Rozporzadzenie RM z dnia 26 kwietnia 1952 r. w sprawie warunków i trybu nadawania stopni naukowych, DzU, 1952, nr 24, poz. 164.

${ }^{3}$ Ust. 8 Obwieszczenia Przewodniczącego CKK dla Pracowników Nauki z 27 czerwca $1953 \mathrm{r}$.

4 „Posiadanie stopnia kandydata nauk jest dowodem przygotowania do samodzielnej pracy naukowej i warunkiem ubiegania się pracownika nauki o tytuł docenta", ust. 1 Obwieszczenia Przewodniczącego CKK dla Pracowników Nauki z 27 czerwca $1953 \mathrm{r}$.

${ }^{5}$ Zupełnie marginesowo można wspomnieć, że od 1959 r. znów nadawane były stopnie doktorskie, B. Baranowski i K. Baranowski, Trudne lata Uniwersytetu Eódzkiego (1949-1956), Łódź 1990, s. 101; zob. też rozdz. Obrony przewodów kandydackich na UŁ, ibidem, s. 99-101.

${ }^{6}$ Promotorem został Józef Litwin, a recenzentami Jan Adamus i Stefan Kieniewicz. 
szlacheckim do monografii, która stała się przedmiotem kolokwium habilitacyjnego. Przez zagadnienia litkupu, problem wyzwalania roli i prawo bliższości w prawie wiejskim, doszła do kardynalnej kwestii związanej zarówno z obrotem prawnym nieruchomościami, jak i szeroko ujmowanym zagadnieniem kształtowania się materialnych podstaw stosunków gospodarczych i społecznych na wsi małopolskiej. Znakomita rozprawa Alienacje nieruchomości w prawie wiejskim w Małopolsce (XVI-XVIII), przygotowana została w warunkach pewnego zniechęcenia związanego z kłopotami z doktoratem, koniecznością objęcia warsztatem badawczym nowych, zupełnie różnych od dotychczasowych, zagadnień i czasów, dodatkowymi obowiązkami wynikającymi z konieczności coraz częstszego zastępowania schorowanego szefa w dydaktyce, potęgowanego jej własnymi, coraz poważniejszymi, kłopotami zdrowotnymi, ukazała się drukiem w 1970 r., w systemie tzw. małej poligrafii, w "szczątkowym” nakładzie. Dając podstawę do formalnego awansu (kolokwium habilitacyjne 23 kwietnia 1971 r.), jednocześnie pokazała wysoki kunszt prawniczy habilitantki. Niestety okazała się ostatnią znaczącą publikacją F. Bortkiewicz. Mimo ogromnych możliwości intelektualnych i rozległych planów, nie udało się doprowadzić żadnego z kolejnych zamierzeń badawczych do szczęśliwego końca. Być może ze względu na skomplikowaną sytuację rodzinną unikała też angażowania się w życie uczelni. I zapewne $\mathrm{z}$ tego powodu nie mogła aktywnie uczestniczyć w działalności organizacji, których była członkiem: Łódzkiego Towarzystwa Naukowego i Polskiego Towarzystwa Historycznego.

W charakterystyce osobowości F. Bortkiewicz zasługuje na podkreślenie jej ogromne zaangażowanie dydaktyczne. Podkreślana we wszystkich opiniach sumienność $\mathrm{w}$ przygotowywaniu się do pracy ze studentami, systematyczność $\mathrm{w}$ aktualizowaniu będących przedmiotem zajęć zagadnień, punktualność, odpowiedzialna konsekwencja w egzekwowaniu studenckich powinności, zwłaszcza przy realizowaniu obciążających ją przez lata obowiązków opiekuna studentów I roku, przy ogromnej życzliwości wobec uczących się, zyskiwały Filomenie Bortkiewicz powszechną sympatię i szacunek.

Była pracownikiem nauki, któremu pełny rozwój kariery utrudniały obiektywne okoliczności. Ostatecznym ciosem okazała się choroba, której medycyna nie potrafiła nie tylko uleczyć, ale nawet poprawnie zidentyfikować7. Nasilające się dolegliwości utrudniały jej przez lata funkcjonowanie,

${ }^{7}$ O diagnozę zwracała się nawet do Kliniki Chorób Tropikalnych i Pasożytniczych w Gdyni. 
by $\mathrm{w}$ ostatnich przed emeryturą latach niemal całkowicie uniemożliwić samodzielne poruszanie się ${ }^{8}$.

Wielokrotnie odznaczana i nagradzana9 ${ }^{9}$ pozostawiła $\mathrm{w}$ pamięci kolegów i studentów obraz człowieka serdecznego, ciepłego, wyrozumiałego.

Spoczęła w Łodzi, na Cmentarzu na Dołach. nych.

${ }^{8}$ Od września 1986 r. do przejścia na emeryturę była zwolniona z zajęć dydaktycz-

${ }_{9}$ Otrzymała m.in. Odznakę Tysiąclecia Państwa Polskiego, Medal KEN, Krzyż Kawalerski Orderu Odrodzenia Polski, była wyróżniana nagrodami ministra edukacji narodowej i rektora Uniwersytetu Łódzkiego. 


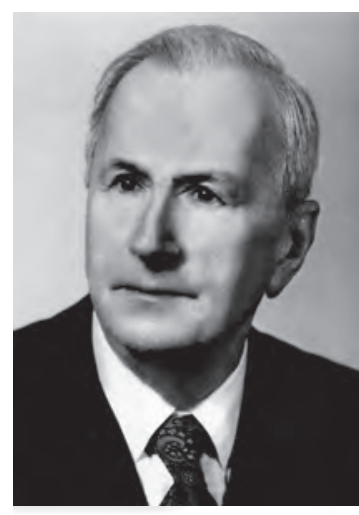

Józef Jagieła

\section{Witold Broniewicz (1923-2013)}

Үo itold Broniewicz urodził się 8 czerwca 1923 r. w Białymstoku ${ }^{1}$. Pochodził z rodziny wywodzącej się z kresów północno-wschodnich. Dzieciństwo i lata młodzieńcze spędził w Wilnie, gdzie uzyskał wykształcenie średnie $w$ gimnazjum oo. Jezuitów (przekształconym rok wcześniej w IX Wileńską Szkolę Średnią). W szkole tej złożył maturę, w przededniu zajęcia Wilna w czerwcu 1941 r. przez wojska niemieckie. Następne lata wojenne spędził $\mathrm{w}$ rodzinnej posiadłości ziemskiej pod Trokami. Po powtórnym zajęciu tamtych terenów przez wojska radzieckie i krótkim epizodzie partyzanckim, został aresztowany i z narażeniem życia uciekł z konwoju NKWD podczas transportu na wschód Rosji. Fakt ten w późniejszych latach wspominał jako najważniejszy epizod swego życia. Po powrocie do Wilna pracował jako robotnik przy pracach geologicznych.

W lipcu 1945 r. przybył wraz z rodzicami do Łodzi i wstąpił na Wydział Prawno-Ekonomiczny założonego właśnie Uniwersytetu Łódzkiego, z którym związał całe swoje życie. W 1949 r., po uzyskaniu stopnia magistra prawa, podjął pracę w Zakładzie Postępowania Cywilnego Uniwersytetu Łódzkiego jako asystent oraz aplikant w Zespole Delegacyjnym Prokuratorii Generalnej, a następnie jako radca prawny Prezydium Rady Narodowej w Łodzi. Przez dziesięć lat łączył pracę naukowo-dydaktyczną z praktyką prawniczą. W 1959 r. uzyskał stopień doktora prawa na podstawie częściowo opublikowanej pracy o przyznaniu w polskim procesie cywilnym. Po otrzymaniu stypendium naukowego w Paryżu (1960-1961) skoncentrował się na pracy naukowej. Habilitował się w 1963 r. na podstawie rozprawy pt. Legitymacja procesowa, tytuł profesora nadzwyczajnego został mu nadany w 1973 r., a profesora zwyczajnego w 1982 r.

${ }^{1}$ Niniejszy biogram został opracowany na podstawie Słowa wstępnego autorstwa prof. dr. hab. Andrzeja Marciniaka, zamieszczonego w Księdze pamiątkowej ku czci Witolda Broniewicza (Symbolae Vitoldo Broniewicz dedicatae, Łódź 1998) oraz przekazów ustnych prof. dr. hab. Witolda Broniewicza. 
Od 1965 r. aż do przejścia na emeryturę w 1993 r. był kierownikiem Katedry Postępowania Cywilnego Uniwersytetu Łódzkiego. W latach 1967-1972 pełnił funkcje Kierownika Studium Zaocznego Wydziału Prawa Uniwersytetu Łódzkiego i prodziekana tego Wydziału. Przez dwie kadencje (1972-1978) Profesor Witold Broniewicz przewodniczył Komisji Prawniczej Łódzkiego Towarzystwa Naukowego. Brał również aktywny udział w pracach Zrzeszenia Prawników Polskich. Ponad dwadzieścia lat kierował redakcją naukowo-dydaktyczną „Folia Iuridica” Uniwersytetu. Przez kilka lat Profesor Witold Broniewicz był członkiem Komisji ds. Reformy Prawa Cywilnego przy Ministrze Sprawiedliwości.

Pod jego kierunkiem stopień magistra uzyskało kilkuset absolwentów Wydziału Prawa i Administracji Uniwersytetu Łódzkiego, przeprowadzone zostały trzy przewody habilitacyjne oraz pięć przewodów doktorskich.

Zasługi Witolda Broniewicza dla rozwoju polskiej nauki prawa postępowania cywilnego są ogromne. Opracowania, których liczba sięga 300 pozycji, w sposób istotny wzbogacają naukę prawa, w szczególności prawa postępowania cywilnego. Zasadnicze zainteresowania naukowe Profesora Witolda Broniewicza koncentrowały się na procesie cywilnym, który jest głównym rodzajem postępowania cywilnego. Profesor zajmował się również zagadnieniami innych działów prawa, zwłaszcza prawa cywilnego, rodzinnego i opiekuńczego oraz prawa pracy, eksponując $\mathrm{w}$ tym zakresie problematykę $\mathrm{z}$ pogranicza prawa procesowego cywilnego i materialnego. $W$ ramach procesu cywilnego szczególnie wiele uwagi poświęcił podmiotom postępowania cywilnego. Wskazują na to przede wszystkim opracowania monograficzne dotyczące legitymacji procesowej i następstwa procesowego.

Wśród opracowań naukowych na uwagę zasługuje przede wszystkim obszerny podręcznik postępowania cywilnego, który doczekał się dziesięciu wydań. Podręcznik ten daje zarys systemu polskiego prawa postępowania cywilnego i należy do czołowych pozycji polskiej literatury postępowania cywilnego. Spośród innych opracowań naukowych wymienić należy dwie książki: Następstwo procesowe w polskim procesie cywilnym (Warszawa 1971) oraz wydany we Włoszech komentarz do polskiego kodeksu postępowania cywilnego w języku włoskim (Codice di procedura civile polacco. Traduzione e commento, Rimini 1981) z bibliografią sięgającą XVI stulecia. Na dorobek naukowy Profesora Witolda Broniewicza składają się ponadto rozprawy, studia i artykuły, glosy do orzeczeń Sądu Najwyższego, recenzje, sprawozdania i inne publikacje, z czego blisko $40 \mathrm{w}$ językach obcych, wydawane za granicą (Włochy, Niemcy, Francja, Japonia, Ukraina), stanowiące niewątpliwie promocję prawa polskiego i polskiej myśli prawniczej. 
„Jestem nastawiony na naukę" - zwykł mówić profesor. Jego mottem była kantowska zasada nullus dies sine linea. Codzienna praca naukowa nie ustawała również w czasie urlopu i wyjazdów wypoczynkowych. Wracając z nich, Profesor dzielił się nie tyle wrażeniami z podróży i nowo poznanych miejsc, ile wynikami swoich przemyśleń naukowych i uzyskanymi rozwiązaniami problemów prawnych.

Profesor Witold Broniewicz był dość surowy w ocenach. Mówił to, co myślał, bez śladu żadnej hipokryzji czy zakłopotania. Ubolewał nad stanem i poziomem współczesnego polskiego ustawodawstwa. Wiele uwag krytycznych odnosił do współczesnej nauki prawa stosowanego. W ostatnich latach wielokrotnie powtarzał - „dzisiaj niewielu zajmuje się ujęciami ogólnymi i kwestiami teoretycznymi. Wszyscy zajęli się pisaniem komentarzy do przepisów prawa”. W związku z tym pytał - „czy czas wielkich XIX-wiecznych teorii procesowych niemieckich i włoskich bezpowrotnie miną??" Wielokrotnie przypominał nam -

nie piszcie komentarzy, to nie jest nauka, nie piszcie o zmianach w kodeksie postępo-
wania cywilnego, to nie jest nauka, jakie są zmiany każdy widzi. Zajmujcie się sferą
teoretyczną postępowania cywilnego. O naukowości rozważań decyduje ich abs-
trakcyjność. Rozważania o wyższym poziomie abstrakcyjności są bardziej naukowe.
Tylko prace naukowe poświęcone ujęciom ogólnym i kwestiom teoretycznym mogą
przetrwać. Inne, ograniczające się do komentowania przepisów prawnych wraz
z utratą ich mocy obowiązującej nabierają wyłącznie znaczenia historycznego.

Profesor Witold Broniewicz wielokrotnie reprezentował polską naukę postępowania cywilnego poza granicami kraju. Utrzymywał żywe kontakty z ośrodkami naukowymi z Włoch, Niemiec, Austrii, Francji, ze Szwajcarii, z Japonii, Ameryki Łacińskiej czy ze Słowacji. Wygłosił wiele wykładów na kilkunastu uniwersytetach zagranicznych (w Kijowie, Tbilisi, Mediolanie, Padwie, Bolonii, Rzymie, Perugii, Katanii, Turynie, Wenecji, Messynie, Sassari, Zurychu, Lyonie, Wiedniu, Bonn, Tokio, Kioto, Atenach).

W uznaniu zasług naukowych Profesor Witold Broniewicz został w 1998 r. uhonorowany księgą pamiątkową Symbolae Vitoldo Broniewicz dedicatae, zawierającą 30 artykułów w różnych językach (polskim, włoskim, niemieckim i francuskim). W 2003 r. Łódzkie Towarzystwo Naukowe dedykowało Witoldowi Broniewiczowi poświęcony mu odrębny zeszyt z serii "Sylwetki Łódzkich Uczonych”. Został też odznaczony i wyróżniony m.in. Krzyżem Kawalerskim i Krzyżem Oficerskim Orderu Odrodzenia Polski, Złotym Krzyżem Zasługi, Medalem Komisji Edukacji Narodowej, Honorową Odznaką m. Łodzi, Złotą Odznaką Uniwersytetu Łódzkiego.

Profesor Witold Broniewicz był członkiem Łódzkiego Towarzystwa Naukowego, Association Henri Capitant, International Association of 
Procedural Law, Wissenschaftliche Vereinigung für Internationales Verfahrensrecht, Institut Canadien Inter-American de Recherche.

Mimo przejścia w 1993 r. na emeryturę Profesor Witold Broniewicz dalej pracował naukowo i przez kilkanaście ostatnich lat prowadził seminarium magisterskie i doktoranckie. Z wielkim zatroskaniem i życzliwością służył ogromną wiedzą i pomocą naukową swoim uczniom i kolegom, poświęcając wiele uwagi metodyce badań naukowych oraz zasadom pisania prac naukowych. Zajęcia dydaktyczne z tego zakresu kończył w każdym roku akademickim następującą wypowiedzią św. Bonawentury:

Trzeba wiedzieć, że są cztery sposoby pisani książki. Są tacy, którzy de facto przepisują tylko myśli innych, nic nie dodając ani nie zmieniając - ci są zwykłymi przepisywaczami. Drudzy „przepisując cudzą książkę" dodają pewne myśli, lecz niestety nie własne - to kompilatorzy. Inni - spisują i swoje, i cudze myśli. Cudze jednak stanowią dominantę, a własne są dołączone jako wyjaśnienie. Tych nazywamy komentatorami. I mamy wreszcie takich, którzy przede wszystkim przekazują własne myśli, a cudzymi posługują się dla wyjaśnienia lub potwierdzenia, czy udowodnienia. Ci rzeczywiście zasługują na miano autorów².

Przez szereg lat Profesor Witold Broniewicz interesował się numizmatyka, co znalazło wyraz w wydaniu ilustrowanego katalogu zgromadzonej przez niego unikalnej kolekcji medali, monet i odznak uniwersyteckich (Łódź 2002). Kolekcję tę Profesor ofiarował Uniwersytetowi Łódzkiemu. Stanowi ona znaczącą część zbiorów Muzeum Uniwersytetu Łódzkiego i jest na stałe eksponowana w Pałacu Biedermanna - siedzibie Muzeum.

Profesor Witold Broniewicz utrzymywał stały kontakt z Wilnem i ze swoimi stronami rodzinnymi. Wyrazem tego było systematyczne zaopatrywanie polskiej Trockiej Szkoły Średniej w książki i kasety video z zakresu polonistyki oraz historii polskiej, a także powszechnej.

2 Św. Bonawentura IV, cyt. za Salezy Kafel OFM CAP, Spotkanie z Bonawentura, „Znak Miesięcznik" 1974, nr 12 (246), s. 1568. 


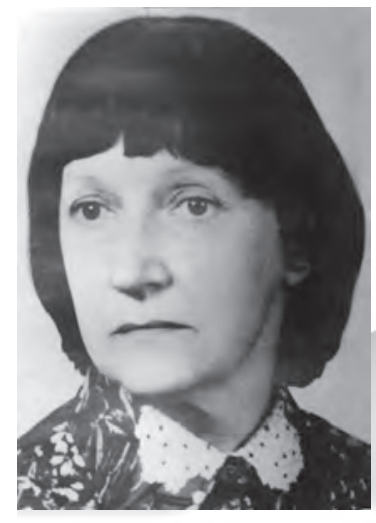

Teresa Dębowska-Romanowska

Natalia Gajl (1921-1998) ${ }^{1}$ C C atalia Gajl (Natalia Dworzańczyk) urodziła się 23 grudnia 1921 r. 1934 skończyła szkołę podstawowa, a następnie, w 1938 r., Gimnazjum Ogólnokształcące. W tymże roku rozpoczęła naukę w Liceum Administracyjno-Handlowym w Chorzowie. Wojna przerwała jej naukę. Przygotowywała się do egzaminów maturalnych sama, a w czerwcu 1940 r. zdała maturę w Liceum Handlowym w Katowicach. Podczas okupacji mieszkała w Warszawie, gdzie zaczęła pracować w firmie węglowej „Giesche” jako pomoc biurowa, podejmując jednocześnie studia na podziemnym uniwersytecie.

Po powstaniu warszawskim trafiła na krótko do Częstochowy, a następnie do Sosnowca. Po wyzwoleniu zamieszkała z rodziną w Katowicach, gdzie w roku 1945/1946 uczęszczała do Wyższej Szkoły Nauk Społeczno-Administracyjnych. W roku 1946 wyszła za mąż za Janusza Gajla, pracownika Politechniki Łódzkiej, żołnierza Armii Krajowej, uczestnika powstania warszawskiego.

Państwo Gajlowie zamieszkali w Łodzi, która odtąd stała się dla nich nie tylko miejscem pobytu, lecz miastem, z którym związali się z wyboru serca. Tutaj urodziły się ich dzieci - Olaf i Karina, a potem wnuki. Ich dom stanowił do końca życia Pani Profesor Gajl znaczące miejsce na mapie życia towarzysko-naukowego Łodzi. Równocześnie z przeniesieniem się do Łodzi rozpoczęła ona studia na Wydziale Prawa Uniwersytetu Łódzkiego - kierunek ekonomiczny. Studia ukończyła we wrześniu 1950 r. i od tego czasu pracowała bez przerwy na Uniwersytecie Łódzkim w Zakładzie

${ }^{1}$ Sporządzono na podstawie: T. Dębowska-Romanowska, Wkład Katedry Prawa Finansowego Wydziału Prawa i Administracji UŁ w procesie transformacji prawa finansowego w II potowie XX wieku, „Acta Universitatis Lodziensis” 1997, Folia Iuridica 64 oraz eadem, Konstytucja, ustrój, system finansowy państwa, Księga pamiątkowa ku czci prof. Natalii Gajl, Warszawa 1999. 
Prawa Finansowego (który w swej historii ulegał licznym przekształceniom organizacyjnym). Z Zakładem tym, a następnie Katedrą Prawa Finansowego, była związana do końca życia.

Została asystentką profesora Jerzego Lubowickiego, przedwojennego wysokiego urzędnika Ministerstwa Skarbu, który kierował Zakładem do swej śmierci, tj. do roku 1964. On też wpłynął znacząco na ukształtowanie jej sylwetki naukowej. Jako przedwojenny skarbowiec przywiązany był do tradycyjnych pojęć podatków, budżetu państwa i systemu dochodów samorządowych, uznając, że te, wykształcone w toku XIX-wiecznej ewolucji ustrojów państw demokratycznych, instytucje mają znaczenie uniwersalne. Zmiany ustrojowe, jakie zaszły w Polsce po roku 1945 nie mogły - jego zdaniem - znieść ani znacząco zmienić ich istoty. Przywiązywał także wagę do badań prawnoporównawczych.

W związku z próbą badań nad opodatkowaniem rolnictwa w krajach socjalistycznych, Natalia Gajl wyjechała w roku 1956 na 6-tygodniowy staż do Związku Radzieckiego. Próba zebrania materiałów zakończyła się niepowodzeniem. Przygotowując nowy temat rozprawy doktorskiej odbyła 3-miesięczny staż we Francji. Badała problemy gospodarki finansowej przedsiębiorstw państwowych. W listopadzie 1959 r. obroniła pracę doktorską. Problematyce systemów finansowych przedsiębiorstw znacjonalizowanych poświęcona była także jej habilitacja. Przeprowadziła w roku 1960 badania nad problematyką finansów przedsiębiorstw znacjonalizowanych we Włoszech, a następnie w roku 1961 w Anglii. We Włoszech ukończyła kurs w Institut universitaire d'études européennes w Turynie, podnosząc kwalifikacje w zakresie prawa porównawczego.

W czerwcu 1963 r., po złożeniu rozprawy habilitacyjnej i zdaniu kolokwium habilitacyjnego, otrzymała stopień naukowy docenta, a od stycznia 1964 r. etat docenta. Tym samym została pierwszą kobietą docentem prawa finansowego $\mathrm{w}$ historii polskiego szkolnictwa wyższego! Z kolei w roku 1970 uzyskała nominację na profesora nadzwyczajnego, natomiast w roku 1976 nominację na profesora zwyczajnego.

Od października 1964 r., po śmierci prof. Lubowickiego, była kierownikiem Katedry Prawa Finansowego. W roku 1981 Katedra Prawa Finansowego przekształciła się w Katedrę Prawa Finansowego i Prawa Zarządzania Gospodarką Narodową.

Od września 1969 r. pełniła funkcję prodziekana Wydziału Prawa i Administracji ds. dydaktyczno-naukowych studium stacjonarnego. Od roku 1972 do 1981 przez dwie kadencje była dziekanem Wydziału, a od roku 1973 do 1981 pełniła funkcję dyrektora Instytutu Administracji. Był to zatem okres ogromnego zaangażowania w sprawy dydaktyczne, naukowe i organizacyjne Wydziału Prawa i Administracji UŁ (m.in. wzniesienie budynku przeznaczonego na cele dydaktyki wydziałowej). 
Jednocześnie, unikając jednoznacznego zaangażowania politycznego, Profesor Gajl starała się w tym okresie być czynna w życiu społecznym i naukowym. Od grudnia 1973 do 1976 r. była zastępcą przewodniczącego Miejskiej Rady Narodowej w Łodzi, następnie od roku 1979 była przewodniczącą Komisji Oświaty, Wychowania i Kultury Rady Narodowej Miasta Łodzi, członkiem Rady Głównej Arbitrażu, Rady Naukowej Instytutu Finansów, Rady Naukowej Ministra Finansów oraz Komisji Nagród Ministra Szkolnictwa Wyższego Nauki i Techniki.

Była również członkiem szeregu zagranicznych towarzystw naukowych, w tym Societé de la Législation Camparée; Institut International de Finances Publiques w Saarbrücken, International Political Science Association Research Committee on Comparative Study of Local Government and Politics, Faculté Internationale de Droit Comparé w Strasburgu i innych.

Wiele razy zapraszana była do wygłaszania wykładów w Institut International de Droit Comparé w Strasburgu i innych ośrodkach uniwersyteckich we Włoszech (Ferrara, Turyn, Neapol), w Wielkiej Brytanii i Japonii oraz mianowana jako professeur associé w Uniwersytecie Paryż I, Paryż II i Paryż III.

W grudniu 1985 r., po utworzeniu Trybunału Konstytucyjnego, została powołana na okres czterech lat na stanowisko sędziego. Powołanie to było dla niej ukoronowaniem dotychczasowej działalności. Pracę w Trybunale wspominała bowiem zawsze jako swoje najważniejsze osiągnięcie. Pełnienie funkcji sędziego Trybunału, w jego pierwszej, historycznej kadencji - niezależnie od ograniczających uwarunkowań politycznych dało jej bowiem możliwość nie tylko realizacji wysuwanych uprzednio postulatów, ale także czynnej obrony praw obywatelskich. Po roku 1989 Profesor Natalia Gajl włączyła się czynnie w prace nad przebudową ustroju finansów publicznych jako ekspert Sejmu i Rządu RP.

Po roku 1992, tj. po przejściu na emeryturę, napisała kilka znaczących monografii naukowych, wiele artykułów i glos oraz ekspertyz dla Sejmu RP; w tym także projekt rozdziału X Konstytucji RP.

Profesor Gajl w różnych okresach swego życia zajmowała się także praktyką prawniczą. W latach 1954-1961 była radcą prawnym w Centralnym Związku Spółdzielni Transportu. Na emeryturze - ku zaskoczeniu swoich uczniów - rozpoczęła praktykę adwokacką i działalność w radach nadzorczych prywatyzowanych przedsiębiorstw państwowych.

Była uosobieniem imponującej pracowitości, hartu ducha i dzielności. Największe nawet ciosy - śmierć córki, ciężka, powracająca choroba - nie były w stanie pozbawić jej chęci życia, cieszenia się nim, siły woli, by tę radość okazywać najbliższym i dzielić ją z innymi.

Zainteresowania naukowo-badawcze profesor Natalii Gajl były w dużej mierze zdeterminowane jej predyspozycjami, które ujawniły się wcześnie 
- już w toku wyboru kierunku kształcenia średniego, a następnie studiów wyższych. Był to bowiem szczególny splot zagadnień prawnych i ekonomiczno-finansowych w odniesieniu do działalności podmiotów publicznych. Stąd wypływała zapewne metodologia naukowa, którą stosowała. W swej pracy naukowej dawała bowiem pierwszeństwo badaniu funkcjonalnemu instytucji finansów publicznych, uwzględniającemu kontekst i skutki ekonomiczne działania tych instytucji - przed badaniami dogmatyczno-prawnymi. Uznawała także uniwersalizm działania instytucji finansowych przy możliwości wyboru spośród wielu wariantowych rozwiązań szczegółowych. Stąd też wprowadzenie przez nią na skalę dotąd niespotykaną $w$ doktrynie prawa finansowego badań prawnoporównawczych. Znaczenie prowadzenia takich badań, a zwłaszcza udostępniania ich efektów studentom - tak, jak to działo się w przypadku jej podręcznika: Finanse i prawo finansowe (Warszawa 1980 i wiele kolejnych wydań), w warunkach państwa tzw. realnego socjalizmu - nie sposób przecenić.

Należy także wziąć pod uwagę, iż w warunkach politycznych lat 1945-1989 badania dogmatyczno-prawne w tak newralgicznej części prawa publicznego, jaką jest prawo finansowe, z góry skazane byłyby na niepowodzenie lub - co jeszcze gorsze - na pozorność. Można zatem z całą odpowiedzialnością stwierdzić, że swoimi badaniami Natalia Gajl stworzyła podstawy rozwoju dogmatycznej nauki prawa finansowego w warunkach wolnej i demokratycznej Polski. Jednocześnie stosowana przez nią metodologia prawnoporównawcza badań przyczyniła się do tego, że doktryna prawa finansowego nie cofnęła się do rozwiązań znanych polskiemu prawu w okresie międzywojennym, lecz uwzględniła skutki dynamicznego rozwoju naszej dyscypliny $w$ państwach demokratycznych w ciągu następnych pięćdziesięciu lat. Dała także, poprzez szereg artykułów, ekspertyz i glos impuls badawczy do prac nad konstytucjonalizacją prawa finansowego $\mathrm{w}$ warunkach działania państwa końca wieku XX.

Ogromny dorobek naukowy (także w sensie liczbowym), szeroki zakres zainteresowań oraz długotrwałość kariery naukowej - to także czynniki, które przyczyniły się do tego, iż jest ona jednym z najczęściej cytowanych autorów, spośród reprezentujących dyscyplinę prawa finansowego.

Pierwszy nurt jej badań koncentrował się wokół problematyki prawnej i finansowej różnych form przedsiębiorczości publicznej lub skomercjalizowanej. W warunkach państwa tzw. realnego socjalizmu przekształcił się on w dyscyplinę nazywaną "Systemy finansowe przedsiębiorstw uspołecznionych". W gospodarce rynkowej badania Profesor Gajl dotyczyły form przedsiębiorczości komunalnej i komercjalizacji przedsiębiorstw państwowych.

Drugi poważny nurt badawczy stanowiła problematyka prawna gospodarki i finansów lokalnych, w tym także przedsiębiorstw lokalnych. 
Prace z tego zakresu nawiązują do praktyki polskiej oraz innych państw. Zasługą Profesor Natalii Gajl jest zainicjowanie badań empirycznych i porównawczych w zakresie gospodarki lokalnej (Struktury prawno-administracyjne i finansowe gospodarki miast uprzemysłowionych, Wrocław 1978). Plonem badań porównawczych prowadzonych z jej inicjatywy przez wielu autorów z Francji, Włoch i Anglii są liczne opracowania i konferencje naukowe. Profesor Natalia Gajl doprowadziła m.in. do wydania pracy zbiorowej (Les problèmes et perspectives des finances locales). Badania te zwieńczone zostały książką Finanse i gospodarka lokalna w świecie (Warszawa 1993).

Osobna, bardzo ważną pozycję w pracy badawczej Profesor Natalii Gajl stanowią studia nad stosunkiem zachodzącym pomiędzy Skarbem Państwa a budżetem. Prace te miały charakter pionierski i nie doczekały się - niestety! - kontynuatorów. Wydarzeniem naukowym była jej monografia Budżet a Skarb Państwa (Warszawa 1974). Niekonwencjonalne ujęcie tematu oraz jego opracowanie sprawiło, że pojawiła się pozycja nie mająca odpowiednika w literaturze światowej. Do tematyki tej wróciła jeszcze raz, już pod kątem potrzeb władzy ustawodawczej, w książce Skarb Państwa (Warszawa 1996, Wydawnictwo Sejmowe).

Problematyka prawna i ekonomiczna budżetu państwa była od dawna najważniejszym polem jej dokonań naukowych. Zajmowała się zwłaszcza zakresem przedmiotowym (powszechnością) budżetu państwa i związkami finansowymi, jakie łączyły lub łączyć powinny wyodrębnione podmioty własności publicznej z tym budżetem. Na uwagę zasługują w tym zakresie studia nad gospodarką budżetową (Gospodarka budżetowa w świetle prawa porównawczego, Warszawa 1993).

Zasługą Natalii Gajl jest podejmowanie tematów trudnych, ważnych teoretycznie oraz praktycznie. Kolejnym tego przykładem jest zorganizowanie badań w zakresie kontroli gospodarczej i finansowej (Zagadnienia kontroli finansowo-gospodarczej przedsiębiorstw i zjednoczeńn'; Podstawowe założenia kontroli finansowo-gospodarczej w państwach socjalistycznych $\left.{ }^{3}\right)$.

W ostatnich latach życia główny ciężar jej badań przesunął się w kierunku studiów prawnoporównawczych i historycznodoktrynalnych nad podatkami. W pierwszym rzędzie wymienić należy wielokrotnie przytaczane Teorie podatkowe w świecie ${ }^{4}$ a następnie publikacje poświęcone modelom podatkowym (Modele podatkowe - podatki dochodowe ${ }^{5}$, Modele podatkowe - podatki obrotowe i inne formy obciażeń pośrednich ${ }^{6}$.

\footnotetext{
2 Pod red. N. Gail, Wrocław 1973.

${ }^{3}$ W: Kontrola administracji w państwach socjalistycznych, red. J. Łętowski, Wrocław 1983.

${ }^{4}$ Warszawa 1992.

5 Warszawa 1995.

${ }^{6}$ Warszawa 1995.
} 
Prace naukowe Natalii Gajl nie ograniczały się do prawa finansowego. Są również szeroko związane z problematyką ustrojową, gospodarczą i administracyjną (Instrumenty finansowe w zarzadzaniu gospodarka narodo$w a^{7}$, Modele zarządzania i finansowania przedsiębiorstw uspołecznionych - Studium prawno-porównawcze $e^{8}$.

Wskazując na podstawowe nurty badawcze i pisarskie $\mathrm{w}$ dorobku Profesor Natalii Gajl nie sposób pominąć prac o charakterze dydaktycznym (Źródła prawa finansowego; Finanse i prawo finansowe; Systemy podatkowe różnych państw).

Osobnej uwagi wymaga jej działalność orzecznicza w Trybunale Konstytucyjnym. Przytoczyć trzeba zwłaszcza zapadłe pod jej przewodnictwem orzeczenie z 19 października 1988 r. (Uw 4/88), w którym z racji stwierdzenia niezgodności rozporządzenia wykonawczego z ustawą sformułowana została po raz pierwszy w orzecznictwie Trybunału zasada wyłączności ustawy, jeśli chodzi o unormowanie obowiązków podatkowych - w jej aspekcie materialno-prawnym. W orzeczeniu tym wskazano, iż

ustawa nie może powierzać aktom wykonawczym takich treści, które określają konstrukcję podatku (podmiot, przedmiot, podstawę opodatkowania, stawki). Takie upoważnienie prowadziłoby $\mathrm{w}$ istocie do ominięcia zasady ustawowej regulacji obowiązków.

Zasada ta znalazła następnie bezpośredni wyraz w brzmieniu art. 217 Konstytucji. W innym orzeczeniu (z 29 października 1986 r., sygn. akt U 2/86) jako sprawozdawca podkreślała, że nie może być uznane za zgodne z Konstytucją przenoszenie przez Radę Ministrów upoważnienia ustawowo jej udzielonego na inne organy administracji o właściwości szczególnej, gdy w grę nie wchodziły res internae administracji państwowej, lecz określenie sfery swobód i powinności obywateli oraz przedsiębiorstw handlowych (chodziło o określenie zasad reglamentacji obrotu niektórymi towarami).

$\mathrm{Z}$ kolei $\mathrm{w}$ innym orzeczeniu zapadłym pod jej przewodnictwem (z 26 września 1989 roku, sygn. akt K. 3/89) wskazano, że ustalenie dopłaty mającej $\mathrm{w}$ istocie znamiona podatku $\mathrm{w}$ innym akcie ustawowym niż ustawa podatkowa, $\mathrm{tj}$. $\mathrm{w}$ ustawie o cenach, spowodowało, iż danina ta została nałożona niezgodnie z powszechnie uznawanymi $\mathrm{w}$ doktrynie zasadami podatkowymi. W wyniku przesądzenia przez ustawę, że dopłata ta stanowi element kalkulacyjny ceny, nie mogły zostać uwzględnione zasady równości i sprawiedliwości, pewności oraz ekonomiczności obcią-

\footnotetext{
7 Warszawa 1979.

8 Warszawa 1986.
} 
żenia. Najbardziej naruszona została zasada pewności (stabilności) prawa podatkowego oraz jednokrotności obciążania.

Działalność orzecznicza Profesor Gajl przyczyniła się zatem nie tylko do obrony praw obywatelskich $\mathrm{w}$ dziedzinie prawa podatkowego, lecz także do wypracowania materialno-prawnych standardów, wedle których ustawy podatkowe winny być oceniane. Te poglądy wpłynęły kształtująco na linię orzeczniczą Trybunału Konstytucyjnego oraz doczekały się rozwinięcia w pracy orzeczniczej jej następców.

Profesor Natalia Gajl była wychowawcą licznej rzeszy studentów, a także opiekunem naukowym wielu młodych pracowników. Zjej pomocy naukowej korzystała duża grupa osób, niemalże ze wszystkich ośrodków akademickich w Polsce, które potem uzyskały stopnie i tytuły naukowe. Była recenzentem przewodów doktorskich, habilitacyjnych, jak również opiniowała wielu młodszych profesorów prawa finansowego w zakresie nadania im stopnia profesora nadzwyczajnego bądź zwyczajnego. Była dla nich nie tylko autorytetem naukowym, lecz także przyjaznym Człowiekiem o wielkiej radości życia - mimo spotykających ją ciosów - i niezwykłej życzliwości dla ludzi, ich spraw i trosk.

Uczniowie Profesor Natalii Gajl są już dziś profesorami, kierującymi samodzielnie zespołami naukowymi i niejednokrotnie pełniącymi ważne funkcje w judykaturze oraz służbie publicznej. 





Barbara Jaworska-Dębska

\section{Bronisław Graczyk (1909-1986)}

Rronisław Graczyk urodził się 13 listopada 1909 r. w Rudnikach, w poSwiecie wieluńskim, jako syn Kazimierza i Jadwigi z domu Mieszkalskiej. Był specjalistą z zakresu prawa administracyjnego i nauki administracji.

Trudne warunki ekonomiczne, w jakich przyszło dorastać B. Graczykowi, jednemu z sześciorga dzieci rolników prowadzących niespełna czterohektarowe gospodarstwo rolne, sprawiły, że jego droga do edukacji naznaczona była równoległą pracą zawodowa, niezbędną do zapewnienia środków utrzymania, a także samokształceniem, którego efekty potwierdzane były następnie egzaminami państwowymi.

Małe gospodarstwo rolne rodziców B. Graczyka nie pozwalało na zbudowanie stabilnych podstaw utrzymania licznej rodziny, a tym bardziej kształcenia dzieci. W tych okolicznościach B. Graczyk w swych nieprzerwanych dążeniach do osiągnięcia wykształcenia praktycznie od początku był zdany na własne siły. Siedmioklasową szkołę powszechną ukończył w 1924 r. w rodzinnych Rudnikach. Ogromne chęci kontynuowania nauki musiały jednak ustąpić konieczności podjęcia pracy zarobkowej. Zaraz po ukończeniu szkoły powszechnej rozpoczął praktykę biurową w Zarządzie Gminy Rudniki, za co - w uznaniu jego szczególnej przydatności - już po niedługim czasie zaczął otrzymywać bardzo skromne wynagrodzenie. W 1925 r., mając niespełna 16 lat, za odłożone pieniądze wyjechał na prowadzony przez Szkołę dla Urzędników Administracji Gminnej w Warszawie pięciomiesięczny kurs dla pracowników samorządowych, który w czerwcu tego roku ukończył jako Primus, mimo że był wśród absolwentów najmłodszy. To wyróżnienie stało się dla młodego B. Graczyka dodatkowym impulsem do dalszego zdobywania wykształcenia, jednakże

${ }^{1}$ Dane pochodzą z akt osobowych Bronisława Graczyka przechowywanych w Archiwum Uniwersytetu Łódzkiego. 
zamiar ten musiał ustąpić konieczności wykonywania pracy zarobkowej na utrzymanie własne oraz pomoc rodzinie. Dlatego po powrocie z Warszawy z zadowoleniem przyjął posadę pomocnika sekretarza $\mathrm{w}$ gminie Rudniki, gdzie pracował od 1 września 1925 r. do 12 maja 1927 r., to jest do chwili, gdy w Zarządzie Gminy Rudniki pojawiła się inspekcja powiatowa, która bardzo wysoko oceniła umiejętności zawodowe młodego urzędnika. W rezultacie tej oceny niespełna osiemnastoletni wówczas B. Graczyk uzyskał awans, został bowiem przeniesiony do Starostwa Powiatowego w Wieluniu, gdzie od maja 1927 r. do sierpnia 1938 r. pracował kolejno jako sekretarz administracyjny, a następnie kierownik referatu. Kolejnym szczeblem kariery urzędniczej B. Graczyka była praca w Urzędzie Wojewódzkim w Łodzi, gdzie od września 1938 r. do września 1939 r., czyli do czasu ewakuacji, zajmował stanowisko kierownika referatu.

Oprócz właściwej pracy urzędniczej B. Graczyk angażował się też w działalność popularyzatorską i szkoleniową. W latach 1936-1939 w prasie codziennej i w periodykach ukazywały się artykuły i przyczynki jego pióra z zakresu prawa i ekonomii. W tym czasie prowadził też szkolenia dla pracowników administracji powiatowej.

W okresie przedwojennym praca zawodowa B. Graczyka i uzyskiwanie przezeń wykształcenia przebiegały równolegle. W zdobywaniu wykształcenia był on zdany na własne siły. Wspomagając się jedynie korepetycjami, sam przerobił pełny program gimnazjum i w roku 1929 zdał egzamin wstępny na Wolną Wszechnicę Polską w Warszawie, który był równoważny egzaminowi dojrzałości typu humanistycznego. Natomiast studia wyższe w zakresie prawa na Wydziale Prawa i Nauk Ekonomiczno-Społecznych - wciąż pracując zawodowo - odbywał w latach 1929-1936 z przerwami wynikającymi z przyczyn ekonomicznych. Absolutorium uzyskał w 1936 r., dyplom zaś w 1938 r., po przygotowaniu pracy Administracja państwowa i jej właściwości strukturalne. Warto tu zaznaczyć, że po uzyskaniu wspomnianego absolutorium, w latach 1936-1939 na Wolnej Wszechnicy Polskiej odbywał też studia ekonomiczne, których nie udało mu się jednak ukończyć z powodu wybuchu drugiej wojny światowej. Zdołał to zrobić dopiero po wojnie.

W czasie okupacji z obawy przed aresztowaniem ukrywał się, dlatego też nigdzie regularnie nie pracował. Nie był jednak bezczynny, zajmował się m.in. tajnym nauczaniem (oprócz historii uczył również muzyki), dorywczo pracował $w$ charakterze robotnika, prowadził buchalterię i sprawy podatkowe dla polskich kupców, tłumaczył pisma niemieckie. Kontynuował też prowadzone już przed wojną samokształcenie, prowadził bowiem samodzielne studia $\mathrm{w}$ zakresie historii i nauk administracyjno-gospodarczych oraz prawoznawstwa. 
Tuż po zakończeniu drugiej wojny światowej B. Graczyk wrócił do pracy w administracji publicznej. Już w styczniu 1945 r. zgłosił się do Gminnej Rady Narodowej w rodzinnych Rudnikach, a w połowie kwietnia 1945 r. - do ostatniego przed wojną miejsca swej pracy, to jest do Urzędu Wojewódzkiego w Łodzi, gdzie do końca 1945 r. pracował na stanowisku radcy w Wydziale Ogólnym. Od stycznia 1946 r., mając już tytuł magistra praw, rozpoczął pracę w Wyższej Szkole Nauk Administracyjnych w Łodzi jako adiunkt oraz kierownik sekretariatu i kwestury Szkoły. Pracę tę kontynuował do sierpnia 1947 r. Od września 1947 r. do czerwca 1951 r. pracował jako naczelnik wydziału prawnego w Okręgowym Urzędzie Likwidacyjnym w Łodzi. Z pracy tej zrezygnował dopiero wówczas, gdy na Uniwersytecie Łódzkim uzyskał zatrudnienie na pełen etat. Od tego czasu cały jego wysiłek i aktywność zawodowa wiązały się z Uniwersytetem Łódzkim, z Wydziałem Prawno-Ekonomicznym, przemianowanym później na Wydział Prawa, a następnie na Wydział Prawa i Administracji.

Pracując zawodowo Bronisław Graczyk uzupełnił przedwojenne wykształcenie. Jako jeden z pierwszych, na podstawie dyplomu Wolnej Wszechnicy Polskiej, w 1945 r. uzyskał na Wydziale Prawno-Ekonomicznym UŁ dyplom magistra praw. W roku 1946 ukończył na UŁ studia ekonomiczne rozpoczęte przed drugą wojną światową na Wolnej Wszechnicy Polskiej w Warszawie. Na UŁ dostrzeżono pasję naukową B. Graczyka rekomendując go do rocznego stypendium na studia we Francji. Choć w 1946 r. stypendium to uzyskał od Ambasady Francuskiej w Warszawie, w porozumieniu z Ministerstwem Oświaty, to jednak wobec opóźnienia w wydaniu paszportu nie mógł z niego skorzystać.

Mimo pozytywnie ocenianej przez zwierzchników pracy $\mathrm{w}$ administracji publicznej i dobrze przebiegającej kariery urzędniczej, B. Graczyk nie łączył jednak swej przyszłości z tą kariera, traktował ją nie jako cel, ale narzędzie prowadzące do celu, jakim było poświęcenie się nauce. Był to cel, do którego zmierzał konsekwentnie i z całych sił. Określając w 1948 r. swe umiejętności fachowe i zainteresowania pisał o sobie: „Prawnik i ekonomista $\mathrm{z}$ wieloletnią praktyką w służbie administracyjnej i samorządowej. Znajomość buchalterii. Zadowolenie znajduję raczej w pracy naukowej niż innej". Droga B. Graczyka ku pracy naukowej była trudna, jak całe jego wcześniejsze dążenie do wiedzy. Jak też pokazało jego dalsze życie, wciąż na tej drodze napotykał różne przeszkody. Oprócz wojny, były to przede wszystkim utrudnienia natury ekonomicznej. Również w okresie powojennym wykonywanie przezeń pracy urzędniczej było konieczne, bo jego droga do kariery naukowej wiodła najpierw (od 1 kwietnia 1947 do 28 lutego 1949 r.) przez asystenturę na zasadzie wolontariatu, a następnie (od 1 marca 1949 do 31 sierpnia 1950 r.) zatrudnienie na pół etatu na stanowisku starszego asystenta, co nie zapewniało wystarczających podstaw utrzymania. 
Mimo braku stałych powiązań formalnych z Uniwersytetem Łódzkim, Bronisław Graczyk od początku uczestniczył w tworzeniu Wydziału Prawno-Ekonomicznego. W latach 1945-1947 wyszukiwał i gromadził księgozbiór, organizował pierwsze pomoce naukowe, brał udział w ustalaniu regulaminów, programów itp.

Zatrudnienie na UŁ w pełnym wymiarze uzyskał dopiero od 1 września 1950 r. Do 31 sierpnia 1951 r. był zatrudniony na Uniwersytecie jeszcze jako starszy asystent. Od 1 września 1951 do 30 września 1964 r. jako adiunkt. W tym czasie, na wniosek dziekana Wydziału Prawa, Senat UŁ w dniu 23 listopada 1954 r. jednomyślnie wystąił do Ministerstwa Szkolnictwa Wyższego o mianowanie mgr. B. Graczyka zastępcą profesora. $\mathrm{W}$ tym również czasie ( $\mathrm{w} 1958 \mathrm{r}$.) na podstawie pracy Postępowanie administracyjne - zarys systemu, uzyskał stopień naukowy kandydata nauk. Od 1 października 1964 do 31 października 1971 r. Bronisław Graczyk był zatrudniony w Katedrze Prawa Administracyjnego, przemianowanej następnie na Zakład Prawa Administracyjnego i Nauki Administracji, jako starszy wykładowca. W 1967 r., po śmierci kierownika Katedry prof. Józefa Litwina, wobec braku w Katedrze samodzielnych pracowników nauki, jako najstarszy wiekiem wziął na siebie ciężar pracy organizacyjnej. Od 1 listopada 1971 r. aż do chwili przejścia na emeryturę 30 września 1977 r. - B. Graczyk był zatrudniony jako docent. Trzej wybitni prawnicy administratywiści tego okresu, profesorowie: Zygmunt Rybicki, Jerzy Starościak oraz Wacław Dawidowicz w swych opiniach zgodnie uznali, że dorobek dr. B. Graczyka w zakresie pracy naukowej, pracy dydaktycznej, jak i w zakresie organizowania procesu nauczania, w pełni uzasadnia wystąpienie o powołanie go na stanowisko docenta. 1 listopada $1971 \mathrm{r}$. dr B. Graczyk został więc powołany na stanowisko docenta bez habilitacji, w uzyskaniu której przeszkadzała mu - jak to określił we wniosku kierowanym do JM Rektora UŁ, dziekana Wydziału Prawa i Administracji UŁ, doc. dr. hab. Janusza Tylmana - „ponad zwykłą miarę intensywna, sumienna, rzetelna i wielostronna działalność w Uniwersytecie Łódzkim". Stanowisko to zajmował do 30 września 1977 r., to jest do przejścia na emeryturę. Warto tu podkreślić, że po rekonwalescencji po zawale serca, który przeszedł w 1977 r., docent Graczyk wrócił do pracy zawodowej, którą w wymiarze 1/3 etatu wykonywał aż do śmierci, która nastąpiła 2 kwietnia 1986 r. w Łodzi.

Jako szczególne osiągnięcie organizacyjne w pracy Bronisława Graczyka na UŁ odnotować należy fakt, że zainicjował on powstanie na Wydziale Prawa UŁ dwustopniowych studiów administracyjnych. Najpierw był organizatorem na UŁ punktu konsultacyjnego Zawodowego Studium Administracyjnego Uniwersytetu Warszawskiego, uruchomionego dla studentów rekrutujących się z terenu Łodzi i województwa łódzkiego, 
za co w 1960 r. otrzymał Nagrodę Ministra Szkolnictwa Wyższego. W latach 1959-1964 kierował tym punktem konsultacyjnym, a od 1964 r. - po utworzeniu Zaocznego Zawodowego Studium Administracyjnego na UŁ - objął jego kierownictwo. Poczynając od 1966 r., po utworzeniu II stopnia magisterskiego Studium Administracji, kierował również nim. Funkcję tę pełnił do chwili przejścia na emeryturę. Warto podkreślić, że studia te, prowadzone w systemie zaocznym, cieszyły się - głównie wśród pracowników administracji - ogromnym zainteresowaniem. Można powiedzieć, że tworząc studia administracyjne, umożliwiające pracownikom administracji uzyskanie wyższego wykształcenia w systemie zaocznym i w cyklu dwustopniowym bez przerywania pracy zawodowej, docent Graczyk dał późniejszym pokoleniom to, czego sam jako młody człowiek potrzebował, a co nie było dla takich jak on łatwo dostępne.

W pasji tworzenia studiów administracyjnych docent Graczyk nie ograniczał się tylko do UŁ. W uznaniu jego zasług na tym polu, 28 grudnia 1965 r. minister szkolnictwa wyższego powołał go na członka zespołu programowego Zawodowego Studium Administracji i Studium Administracji utworzonego w Ośrodku Metodycznym Studiów dla Pracujących w Uniwersytecie im. Adama Mickiewicza w Poznaniu.

Wprawdzie początki pracy dydaktycznej B. Graczyka przypadają na czas, gdy był on starszym asystentem w Wyższej Szkole Nauk Administracyjnych $w$ Łodzi, gdzie prowadził konwersatorium $\mathrm{z}$ ogólnej teorii prawa oraz ćwiczenia z nauki administracji i z prawa administracyjnego, to jednak w szeroko rozumianą działalność dydaktyczną wpisują się też lata 1947-1948, gdy pracując w Okręgowym Urzędzie Likwidacyjnym w Łodzi, B. Graczyk był inicjatorem, współorganizatorem i kierownikiem permanentnych kursów szkoleniowych dla pracowników administracyjnych oraz wykładowcą na kursie referendarskim i kursie dla kandydatów na wicestarostów.

W czasie długoletniej pracy na Wydziale Prawa UŁ, Bronisław Graczyk prowadził w początkowym okresie ćwiczenia, później wykłady kursowe z prawa administracyjnego oraz wykłady specjalizacyjne, m.in. z kontroli administracji, seminaria dyplomowe (na ZSA), seminaria magisterskie (na SA, ale też na prawie dziennym oraz wieczorowym). Prowadził też seminarium doktorskie. Rozległa wiedza z prawa administracyjnego i nauki administracji oraz umiejętność jej prostego i przejrzystego przekazywania sprawiały, że zajęcia dydaktyczne B. Graczyka cieszyły się dużą popularnością. Nie bez znaczenia był również jego ujmujący sposób bycia. Masywna sylwetka docenta Graczyka kontrastowała z wielką elegancją z jaką odnosił się do otoczenia. Dotyczyło to zarówno studentów, młodych asystentów, jak i pozostałych pracowników naukowych oraz pracowników administracji uczelnianej. Jego stosunek do kobiet także 
pełen był rewerencji. W czasie swej pracy na UŁ wypromował on $198 \mathrm{dy-}$ plomantów - absolwentów ZSA oraz 165 magistrantów. Był też promotorem pracy doktorskiej obronionej w $1980 \mathrm{r}$.

Zainteresowania badawcze Bronisława Graczyka można uszeregować $\mathrm{w}$ trzech zasadniczych nurtach: to postępowanie administracyjne, prawo administracyjne materialne, a w nim prawna problematyka stanów nadzwyczajnych podjęta na przykładach ochrony przeciwpożarowej i zapobiegania klęskom żywiołowym (tym nurcie mieszczą się liczne artykuły i hasła encyklopedyczne), wreszcie zagadnienia ustrojowe, w szczególności problematyka rad narodowych i ich komisji (publikacje z tego zakresu zawierają naukową analizę badań empirycznych, a więc ocenę praktyki funkcjonowania przepisów i powołanych na ich podstawie instytucji).

W naukowym dorobku docenta Bronisława Graczyka na szczególną uwagę zasługują dwie pozycje: Postępowanie administracyjne - zarys systemu (Warszawa 1953) oraz Prawo o ochronie przeciwpożarowej (Warszawa 1956), które na trwałe weszły do dorobku polskiego piśmiennictwa w dziedzinie prawa administracyjnego. O wartości pracy poświęconej postępowaniu administracyjnemu dobitnie świadczy fakt, że bardzo długo liczne jej fragmenty nie straciły na aktualności, mimo że w kilka lat po jej opublikowaniu (w 1960 r.) weszła w życie nowa kodyfikacja postępowania administracyjnego. Także praca poświęcona ochronie przeciwpożarowej, mimo upływu czasu i po wielokroć zmienianego stanu prawnego, w swej warstwie teoretycznej wciąż zachowała swą wartość. W dorobku naukowym docenta Graczyka widać też jego niesłabnące zainteresowanie sprawami wsi. Dowodzi tego m.in. bardzo obszerne i gruntowne opracowanie Samorzad mieszkańców ważnym ogniwem w rozwoju działalności społeczno-gospodarczej wsi ${ }^{2}$. Na uwagę zasługuje też jedno z pierwszych opracowań poświęconych pozycji ustrojowo prawnej wojewody Stanowisko wojewody w systemie organów administracji państwowej ${ }^{3}$.

Dorobek naukowy, liczący ok. 90 pozycji, uzupełniają też opracowania o charakterze pomocy dydaktycznych (skrypty) oraz publikacje popularyzatorskie. Świadczą one dobrze o umiejętności jasnego i zrozumiałego ujmowania przez autora trudnych zagadnień prawniczych.

Na przeszkodzie w działalności naukowej Bronisława Graczyka, która zaowocowałaby większą liczbą zwartych opracowań, wymagającej jak wiadomo - skupienia i swoistej wyłączności, stawały wyzwania organizacyjne zarówno te, które sam w znacznej mierze inspirował, jak i te, na które nie miał wpływu, ale w których niepodjęciu przeszkadzało mu silne poczucie obowiązku.

2 "Studia Regionalne" 1981, t. V, s. 3-28.
3 ",Region Łódzki” 1974, nr 4, s. 35-52. 
W okresie całej pracy zawodowej, urzędniczej przed wojna, naukowej po wojnie, B. Graczyk był nagradzany. Przed drugą wojną światową w 1937 r. za zasługi w służbie państwowej otrzymał Brązowy Krzyż Zasługi, natomiast w 1938 r. został uhonorowany Brązowym Medalem za Długoletnią Służbę. Po wojnie za osiągnięcia w pracy naukowo-dydaktycznej i organizacyjnej na Uniwersytecie Łódzkim, Bronisław Graczyk był często wyróżniany przez rektora UŁ (np. w 1950, 19511953 r.). Wielokrotnie był też honorowany odznaczeniami: dwukrotnie, w 1956 r. i w 1962 r., Nagrodą Ministra Szkolnictwa Wyższego, w 1967 r. Odznaką Tysiąclecia Frontu Jedności Narodowej, w 1968 r. Złotą Odznaką Związku Nauczycielstwa Polskiego, w 1970 r. Złotym Krzyżem Zasługi, w 1970 r. Złotą Odznaką Uniwersytetu Łódzkiego, w 1970 r. Odznaką Honorową Województwa Łódzkiego, w 1973 r. Medalem Komisji Edukacji Narodowej, a w 1975 r. Medalem 30-lecia PRL.

Należy podkreślić, że Bronisław Graczyk nigdy nie angażował się politycznie, co w polskiej rzeczywistości, szczególnie lat wczesnopowojennych, nie było łatwe. Przez całe życie pozostał bezpartyjny, natomiast aktywnie działał społecznie. Jego aktywność społeczna w okresie przedwojennym dotyczyła środowiska urzędniczego i studenckiego. W tym czasie należał do Stowarzyszenia Urzędników Państwowych i Bratniej Samopomocy Studentów Wolnej Wszechnicy Polskiej. Okres wojenny był czasem, w którym B. Graczyk starał się przetrwać, nie przystępując do jakichkolwiek organizacji. Natomiast po wyzwoleniu jego dawna aktywność społeczna ponownie dała o sobie znać. Już od kwietnia 1945 r. działał bez przerwy w różnych związkach zawodowych. Początkowo w Związku Zawodowym Pracowników Państwowych, następnie w Związku Zawodowym Pracowników Finansowych, a od kwietnia 1951 r. w Związku Nauczycielstwa Polskiego. Przez dwie kadencje przewodniczył m.in. Zakładowej Organizacji Związkowej ZNP. Aktywnie pracował też w Zrzeszeniu Prawników Polskich, w Polskim Towarzystwie Ekonomicznym, w Towarzystwie Naukowym Organizacji i Kierowania oraz w Sekcji Prawnej Towarzystwa Wiedzy Powszechnej. Pracując na Wydziale Prawa pozostawał w kontakcie $\mathrm{z}$ administracją lokalną. W związku z tym przez długie lata był członkiem Prezydium oraz przewodniczącym Komisji do spraw Informatyki, Organizacji i Zarządzania Rady Naukowej przy Prezydium Wojewódzkiej Rady Narodowej w Łodzi. 



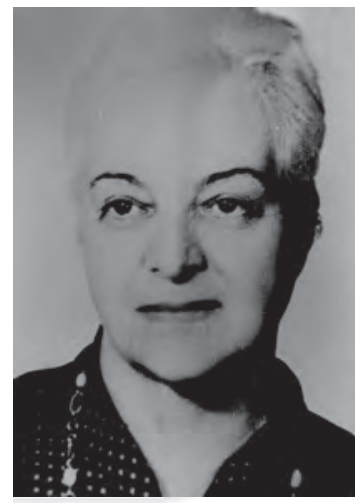

Michat Domagata

\section{Irena Grajewska (1918-1982)}

Yrena Grajewska, córka Roberta i Ireny (z domu Miecznikowska) Andersen urodziła się 7 czerwca 1918 r. w Taganrogu (Rosja - obwód rostowski) w rodzinie inteligenckiej. Doktor habilitowany nauk prawnych, profesor nadzwyczajny Uniwersytetu Łódzkiego, specjalistka z zakresu polskiego, a także porównawczego prawa konstytucyjnego ${ }^{1}$. Ukończyła studia na Wydziale Prawno-Ekonomicznym UŁ (1949 r.). Będąc jeszcze studentką drugiego roku, rozpoczęła pracę jako asystent wolontariusz w Katedrze Prawa Rzymskiego (1946 r.), następnie jako młodszy asystent (1947 r.). Tytuł magistra prawa uzyskała na Wydziale Prawa UŁ w 1949 r. Z dniem 1 stycznia 1953 r. awansowała na stanowisko adiunkta, a od 1 października 1953 r. została zatrudniona na tymże stanowisku w Katedrze Prawa Państwowego.

W 1958 r. uzyskała stopień doktora nauk prawnych na podstawie pracy pt. Koncepcje prawno-ustrojowe Komuny Paryskiej 1871 r., opublikowanej pt. Komuna Paryska 1871 r. Zagadnienia wtadzy proletariackiej (Warszawa 1961). Stopień naukowy doktora habilitowanego otrzymała w 1964 r. na podstawie pracy habilitacyjnej Zagadnienie odpowiedzialności posła wobec wyborców, w wyniku czego została awansowana na stanowisko docenta. Biorąc pod uwagę dotychczasowy dorobek naukowo-badawczy oraz dydaktyczny, Rada Państwa w dniu 4 kwietnia 1974 r. podjęła uchwałę o nadaniu Irenie Grajewskiej tytułu naukowego profesora nadzwyczajnego nauk prawnych. Z dniem 1 października 1977 r. Profesor I. Grajewska przeszła na emeryturę, przy czym pozostała w pełni czynnym pracownikiem naukowym i dydaktycznym (była zatrudniona w Katedrze Prawa Państwowego w niepełnym wymiarze godzin), o czym świadczą jej kolejne liczne publikacje oraz szeroko zakrojone badania naukowe.

1 T. Szymczak, Irena Grajewska. Wspomnienie pośmiertne, „Państwo i Prawo” 1983, z. 4. Opinie i recenzje dorobku naukowego prof. dr hab. I. Grajewskiej zaczerpnięto z akt I. Grajewskiej przechowywanych w Archiwum UŁ. 
Zainteresowania naukowe Ireny Grajewskiej zasadniczo ugruntowały się po przejściu do Katedry Prawa Państwowego. Jej twórczość naukowa jest bardzo zróżnicowana pod względem tematycznym i w znacznym stopniu ukierunkowana historycznie. Jako pracownik naukowy cechowała się dużą sumiennością i rzetelnością badawczą oraz od powiedzialnością za głoszone poglądy. W jej dorobku naukowym możemy wyróżnić kilka zasadniczych nurtów. Pierwszym, podstawowym, kierunkiem badań jest problematyka ustrojowa Komuny Paryskiej. Wymagało to wszechstronnej znajomości teorii państwa, prawa państwowego, historii doktryn politycznych XIX w. i, nade wszystko, historii Francji, do której wracała nieraz w innych swoich pracach. Dziełem, które na trwałe weszło do literatury przedmiotu, jest monografia Komuna Paryska 1871 r. Zagadnienia władzy ludowej. Książka ta doczekała się trzech wydań i wielu pochlebnych recenzji. Recenzenci są zgodni, że Irena Grajewska była najlepszą w Polsce znawczynią zagadnień Komuny, że jej dzieło nie ma równego sobie w naszej literaturze przedmiotu. Poszczególne wydania miały nieco zmodyfikowane tytuły. Były one przerabiane i poszerzane w wyniku dotarcia do nowych materiałów źródłowych i ich wykorzystania, np. wydanie II (Warszawa 1971) zostało poszerzone i uzupełnione o 30\% tekstu.

Poza tym Profesor Irena Grajewska poświęciła różnym problemom ustrojowym Komuny Paryskiej siedem artykułów, które opublikowała w krajowych czasopismach, jeden zaś zamówiony został przez paryską "La Pensec". Na międzynarodowym francusko-polskim kolokwium poświęconym setnej rocznicy Komuny Paryskiej (20-24 kwietnia 1971 r.) wygłosiła referat pt. Nouvelle conception de la representation populaire dans la Commune de Paris (1871).

Drugi kierunek badawczy, również o charakterze historycznym, dotyczy także francuskiego prawa konstytucyjnego, jednakże z innych okresów. Efektem tych zainteresowań są m.in. następujące opracowania: Z problematyki prawa wyborczego francuskiej monarchii parlamentarnej ${ }^{2}$, Walka o demokratyzacje przedstawicielstwa w zaraniu III Republiki Francuskiej ${ }^{3}$, a także recenzja monografii P. Bastid pt. Les institutions politiques de la Monarchie parlementaire française (1814-1848), Paryż 1954.

Kontynuacją nurtu francuskiego są badania i publikacje dotyczące problematyki ustrojowej V Republiki Francuskiej. W tym zakresie Irena Grajewska opublikowała szereg prac na temat prawa wyborczego, roli ustrojowej partii politycznych, wzajemnych relacji pomiędzy prezydentem Republiki a premierem oraz rządem, a także pomiędzy premierem

\footnotetext{
2 "Zeszyty Naukowe Uniwersytetu Łódzkiego" [dalej: ZNUŁ] 1958, ser. I, z. 9.

${ }^{3}$ ZNUŁ, 1964, ser. I, z. 35.

4 „Państwo i Prawo” [dalej: PiP] 1957, z. 9.
} 
a rządem. Wśród nich możemy wymienić m.in. Przemiany w egzekutywie $V$ Republiki Francuskiej ${ }^{5}$, Ewolucja stosunku między rzadem a parlamentem w V Republice Francuskiej', a także Niektóre problemy francuskiego prawa wyborczego. Zagadnienia współczesnego prawa państwowego (Wrocław-Warszawa-Kraków 1967). Przedmiotem badań były także zagadnienia funkcjonowania Rady Konstytucyjnej V Republiki na tle francuskiej tradycji ustrojowej. W efekcie wnikliwej analizy regulacji konstytucyjnych i ich konfrontacji z rzeczywistością, Profesor I. Grajewska dostrzegła znaczącą rozbieżność pomiędzy faktyczną pozycją każdego z tych organów a modelem konstytucyjnym, która jest wynikiem przekształceń natury zwyczajowej. Na podstawie tych badań zostały sformułowane ciekawe wnioski co do charakteru ustrojowego V Republiki Francuskiej i perspektyw ewolucji w tej dziedzinie. Rozważania te miały niezwykle istotne znaczenie dla dalszego rozwoju badań porównawczych w nauce prawa konstytucyjnego.

Kolejnym nurtem jej naukowych zainteresowań były problemy reprezentacji politycznej, w szczególności węzłowe zagadnienia demokracji, jak kwestia charakteru mandatu przedstawicielskiego, a przede wszystkim wzajemnego stosunku pomiędzy posłem a wyborcami. Bardzo istotną kwestią $\mathrm{w}$ tym zakresie jest rola partii politycznych, uwzględniona przez autorkę z wyjątkową znajomością rzeczy. Podstawowym opracowaniem $\mathrm{w}$ tej dziedzinie jest rozprawa habilitacyjna pt. Zagadnienie odpowiedzialności posła wobec wyborców. Profesor Grajewska zarówno przed, jak i po uzyskaniu stopnia naukowego doktora habilitowanego opublikowała szereg artykułów dotyczących charakteru mandatu przedstawicielskiego, różnych problemów z zakresu prawa wyborczego, jak również roli partii politycznych w funkcjonowaniu systemów przedstawicielskich w różnych państwach. Świadczy to o szerokich prawnoporównawczych zainteresowaniach i dogłębnej wiedzy w tym zakresie. Do najważniejszych publikacji z tej grupy możemy zaliczyć: Zagadnienie odpowiedzialności deputowanego wobec wyborców we Francji,$W$ sprawie odwoływalności posłów ${ }^{8}$, Odpowiedzialność posła brytyjskiego wobec partii i wyborców $w^{9}$, Partie masowe a system przedstawicielski - próba syntezy ${ }^{10}$. Wymienione powyżej opracowania stanowią poważny wkład w rozwój nauki prawa konstytucyjnego.

Wśród zainteresowań naukowych Profesor Ireny Grajewskiej znalazła się także problematyka podstawowych zasad ustrojowych. Efektem

\footnotetext{
${ }^{5} \mathrm{PiP}, 1970$, z. 11.

6 ZNUŁ, 1971, ser. I, z. 83.

7 PiP, 1956, z. 11.

8 PiP, 1956, z. 8-9.

9 ZNUŁ, 1964, ser. I, z. 37.

10 ZNUŁ, 1963, ser. I, z. 31.
} 
tego są m.in. następujące publikacje: Z problemów demokratycznego centralizmu ${ }^{11}$, Wspótczesna treść zasad ustrojowych burżuazyjnej demokracji ${ }^{12}$.

Charakterystyczną cechą twórczości naukowej Ireny Grajewskiej była duża rzetelność badawcza, wnikliwość analizy, wielostronność spojrzenia na badane problemy, a także nowatorskie podejście do omawianych zagadnień. Nigdy nie unikała podejmowania tematów bardzo trudnych, wymagających dużego zasobu wiedzy nie tylko z zakresu prawa konstytucyjnego, lecz także z różnych dyscyplin pokrewnych, takich jak historia doktryn politycznych, teoria państwa, filozofia, historia państwa i prawa. We wszystkich publikacjach jej autorstwa widoczny jest duży wkład pracy, maksymalne i krytyczne wykorzystanie literatury przedmiotu, a także dogłębna dokumentacja oparta na dostępnych źródłach.

W prawniczym środowisku naukowym wysoko ceniony był jej udział w krajowych i międzynarodowych konferencjach, sesjach i sympozjach, na których prezentowała wiele referatów oraz uczestniczyła w dyskusji.

Poza bogatą twórczością naukowo-badawcza, Profesor I. Grajewska była cenionym pracownikiem dydaktycznym. Prowadziła wykłady dla studentów studiów stacjonarnych i zaocznych z polskiego prawa konstytucyjnego oraz prawa porównawczego. Była promotorką ponad trzystu prac magisterskich i dyplomowych. Swoje doświadczenia, wynikające z pracy dydaktyczno-wychowawczej ze studentami, potrafiła uogólnić i prezentować $\mathrm{w}$ publikacjach o charakterze naukowo-popularyzatorskim, jak również w referatach na sesjach Katedr Prawa Państwowego. Świadczą o tym ciekawe artykuły zamieszczane w "Życiu Szkoły Wyższej", a także w pracy zbiorowej Zagadnienia dydaktyki szkót wyższych, Warszawa 1968 (W poszukiwaniu źródeł odsiewu na wyższych uczelniach - oraz Studenci o problemie sprawności nauczania). Studenci wysoko cenili zajęcia dydaktycznie prowadzone przez I. Grajewską. O ich efektywności mogą świadczyć najwyższe nagrody uzyskiwane przez jej magistrantów i dyplomantów, których prace uczestniczyły w wielu konkursach centralnych i lokalnych.

Za swą działalność naukową i dydaktyczną Profesor Irena Grajewska została odznaczona Krzyżem Kawalerskim Orderu Odrodzenia Polski, Złotym Krzyżem Zasługi, Medalem Komisji Edukacji Naukowej, Medalami X i XX-lecia PRL oraz wieloma nagrodami ministra nauki, szkolnictwa wyższego i techniki, a także rektora UŁ.

Zmarła w 64. roku życia, w Łodzi, po krótkiej, niespodziewanej chorobie, 24 grudnia $1982 \mathrm{r}$.

11 „Studia Prawno-Ekonomiczne” [dalej: SPE] 1970, t. IV.

12 SPE, 1971, t. VII. 


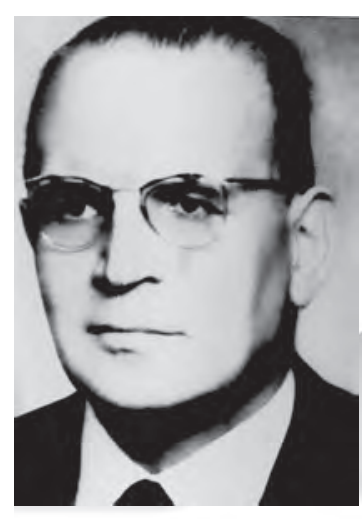

Jacek Matuszewski

\section{Henryk Grajewski (1913-1971)}

Cenryk Grajewski, trzeci z kolei kierownik Katedry Historii Państwa Uniwersytetu Łódzkiego, z którym związał swą karierę nauczyciela akademickiego. Trudno powiedzieć, skąd się u niego pojawiła naukowa pasja. Urodzony 16 lipca 1913 r. w niezamożnej łódzkiej rodzinie (ojciec Adam - księgowy, matka - Elżbieta, bez zawodu) podjął naukę w gimnazjum, a następnie (1932 r.) - pozostając na własnym utrzymaniu, przede wszystkim z korepetycji - zapisał się na studia na Wydziale Prawa Uniwersytetu Warszawskiego. Ich ukończenie nie otwierało przed nim możliwości ubiegania się o wymarzoną aplikanturę sądowa gdyż ze względu na pochodzenie ta droga zawodowa była przed nim w latach rządów sanacji zamknięta. Wrócił do Łodzi, gdzie początkowo jako biuralista w Łódzkiej Fabryce Barwników Chemicznych Barwarat (1932-1934), a później, do 1939 r., jako korepetytor, bezskutecznie szukał możliwości zawodowej stabilizacji, wciąż jednak systematycznie dbając o własny rozwój zawodowy.

Wojna wypędziła go na Kresy, gdzie w Lidzie, Baranowiczach i Mostach spędził jako urzędnik pierwsze lata okupacji (1939-1941)1. Następnie (lipiec 1941 - czerwiec 1944 r.) - znów utrzymując się z korepetycji - mieszkał w Wilnie, by po roku od wkroczenia tam Armii Czerwonej zdecydować się na powrót do Łodzi². Tu został zatrudniony początkowo jako kierownik Oddziału Karno-Administracyjnego w Starostwie Grodzkim Śródmiejsko-Łódzkim, a następnie jako zastępca naczelnika Biura

${ }^{1}$ Obejmując rozmaite stanowiska (był kasjerem i planistą w firmie budowlanej Granit w Lidzie, kierownikiem planowania w Masłopromie w Baranowiczach i w podobnym charakterze $\mathrm{w}$ Wilnie) poznał $\mathrm{w}$ praktyce funkcjonowanie prawa $\mathrm{w}$ sferze publicznej.

${ }^{2} \mathrm{~W}$ czasie wojny stracił oboje rodziców; z najbliższych pozostała mu tylko siostra, która w 1946 r. wyjechała na stałe do Paryża i stanowiła dla brata ostoję w trakcie jego francuskich wyjazdów zarówno gdy poświęcał się poszukiwaniom bibliotecznym, jak i wówczas, gdy podstawowym celem pobytu było leczenie postępującej choroby. 
Prezydialnego Zarządu Miasta i kierownik Wydziału Organizacyjnego (1945-1950). Wówczas zrodziła się w nim pasja naukowa33. W latach 19461950 systematycznie prowadził cykle odczytów popularnonaukowych dla pracowników zrzeszonych w Związku Zawodowym Pracowników Samorządu Terytorialnego i Instytucji Użyteczności Publicznej oraz dla zatrudnionych w Zarządzie Miejskim i Urzędzie Wojewódzkim, a już w styczniu 1949 r. Eugeniusz Stawiński, prezydent Miasta Łodzi wystapił do rektora UŁ z poparciem prośby o zatrudnienie Henryka Grajewskiego w charakterze asystenta na Wydziale Prawa.

Od 1 lutego 1949 r. został asystentem ${ }^{5}$ w Katedrze kierowanej (do 1951 r.) przez przyszłego promotora, dr. Mariana Grabskiego. Przełożony, mimo że niezmiernie życzliwy, nie był w stanie pokierować, pomagać, czy w jakikolwiek sposób wpływać na aktywność badawczą młodego pracownika, gdyż sam nauką się nie zajmował' ${ }^{6}$. Stąd Henryk Grajewski rozwijał się jako samouk, zwłaszcza że kolejny z szefów, Stanisław Śreniowski, uczony z dobrej, przedwojennej, lwowskiej szkoły, po początkowym, intensywnym zaangażowaniu $\mathrm{w}$ przerobienie i rozszerzenie przygotowywanego do publikacji doktoratu ${ }^{7}$, szybko zapałał do swego pracownika

${ }^{3}$ Wspomina co prawda, że: „Moje zainteresowania badawcze powstały już w czasie studiów, warunki jednak materialne nie pozwoliły mi wówczas na podjęcie pracy badawczej”; ostatecznie jednak stwierdza: „W okresie pracy na stanowisku [...] obudziło się we mnie zainteresowanie teoretycznym opracowaniem zagadnień wykroczeń karno-administracyjnych oraz wpływem alkoholizmu na przestępczość. Z tego okresu datuje się moja pierwsza praca: Analiza przepisów ustawy antyalkoholowej na tle praktyki starostw grodzkich i orzecznictwa Sądu Okręgowego w Łodzi. Było to studium oparte na opracowaniu materiałów aktowych (1000 spraw o opilstwo). Wnioski końcowe tej pracy referowałem na seminarium kryminologicznym prof. Batawii w 1947 r." Tak pisał w sporządzonej w 1953 r. „Ocenie własnej działalności naukowej". [Jeżeli nie zaznaczono inaczej, materiały pochodzą z akt osobowych w Archiwum UŁ].

${ }^{4}$ Przedstawia w nich m.in. tematy: Reforma rolna, Ustrój Polski Ludowej, Istota konstytucji PRL, Pochodzenie państwa i prawa, Istota prawa, Typy i formy państwa i prawa, Teoria kary w społeczeństwie burżuazyjnym, System kar w kodeksie karnym, Postępowanie administracyjne, Orzecznictwo karno-administracyjne, Ustawa przeciwalkoholowa, Wymiar kary.

${ }^{5}$ Przez ponad rok próbując łączyć pracę w magistracie - jeszcze w lutym i marcu był wykładowcą na Wyższym Kursie Korespondencyjnym Ministerstwa Administracji Publicznej - z zatrudnieniem na uczelni.

6 "Jestem przekonany, że ówczesny magister i asystent tegoż” - pisał Jan Adamus w swoim referacie uzasadniającym wniosek o docenturę - „ob. Grajewski, łatwiej sobie od razu dawał radę z wielu problemami naukowymi, niż jego kierownik katedry".

7 „Rychło stał się jednakże pupilem śp. prof. Śreniowskiego [...] Zainteresował się żywo prof. Śreniowski” - cytujemy dalej opinię Jana Adamusa - „wydaniem drukiem pracy [doktorskiej] Grajewskiego, ale z tym wiązał przeróbki i rozszerzania czasowe tematu". Niesłychanie rzetelnie źródłowo przygotowana rozprawa Kara śmierci w polskim prawie karnym epoki przedfeudalnej, opublikowana w 1956 r. jako: Kara śmierci w prawie 
- delikatnie rzecz ujmując - serdeczną niechęcią, szkodząc mu wręcz na każdym kroku9. W efekcie od 1953 r. doszło do zmiany statusu pracowniczego młodego historyka prawa, który po doktoracie (1951 r.) nie chciał się naukowo podporządkować despotycznemu, opanowanemu chłopomania, zwierzchnikowi.

W tej sytuacji Grajewski nie tylko nie mógł liczyć na naukową pomoc przełożonego, ale pozbawiony został możliwości prowadzenia dydaktyki w Katedrze, w której był zatrudniony. Dzięki opiece Jana Adamusa, w latach 1953-1957 prowadził na podstawie umowy zlecenia wykłady z powszechnej historii państwa i prawa oraz z historii ustroju Związku Radzieckiego, pełniąc równocześnie funkcję sekretarza naukowego Zespołu Katedr Historyczno-Prawnych, ale ostatecznie i tak 1 września 1955 r. musiał przenieść się do Katedry Powszechnej Historii Państwa i Prawa. Dopiero po śmierci Stanisława Śreniowskiego (11 sierpnia 1957 r.) pojawiła się możliwość stabilizacji. Adamus, kurator osieroconej Katedry, wspierał mocno starania Wydziału o usamodzielnienie Grajewskiego. Próba rozwiązania kwestii obsady samodzielnym pracownikiem Katedry Historii Państwa i Prawa Polskiego polegała na wystosowaniu wniosku o powołanie Henryka Grajewskiego na stanowisko docenta. Uchwała Rady Wydziału Prawa UŁ w tej kwestii podjęta została już 18 października 1957 r., ale mimo jednomyślności na posiedzeniach Rady Wydziału i Senatu UŁ

polskim do połowy XIV wieku dotknięta została, najpewniej pod wpływem Śreniowskiego, intensywnym odwoływaniem się do marksistowskich autorytetów. Takie ujęcie w $1973 \mathrm{r}$. jako zaletę studium przedstawia W. Sobociński: „dzięki konsekwentnemu zastosowaniu $\mathrm{w}$ pracy materializmu historycznego nie popada bynajmniej w formalizm prawniczy". ("Czasopismo Prawno-Historyczne” [dalej: CPH], t. XXV, z. 1, s. 236) i podobnie charakteryzuje twórczość Grajewskiego w odniesieniu do innych publikacji: „Nie unikał też konstrukcji teoretycznych [...] było to jednak podejście do zagadnień teoretycznoprawnych (a podobnie dogmatycznych) należycie pogłębione przez materializm historyczny" (ibidem, s. 239).

${ }^{8}$ Powodów możemy się tylko domyślać, bo nawet stojący blisko wydarzeń Jan Adamus nie wiedział, albo nie chciał wiedzieć, o co naprawdę poszło: „W końcu z niewyjaśnionych jasno powodów, których nie zdołałem zrozumieć pomimo wysłuchiwania szczegółowych zarzutów, wybuchł konflikt i prof. Śreniowski nabrał sporego uprzedzenia do dr. Grajewskiego". Wydaje się, że zarzewie konfliktu tkwiło w obawie przed konkurencją. Oto jak Śreniowski opiniował w grudniu 1954 r. wniosek o nadanie tytułu zastępcy profesora: „uprzejmie komunikuję, że nie ma obiektywnych warunków, które by uzasadniały powierzenie dr. Henrykowi Grajewskiemu funkcji dydaktycznych i naukowych przy katedrze historii państwa i prawa polskiego UŁ w zakresie spełnianym przez samodzielnego pracownika nauki, jak również, że dr H. Grajewski nie posiada kwalifikacji wymaganych do nadania tytułu zastępcy profesora".

${ }^{9}$ W przechowywanych w BUŁ papierach po prof. Henryku Grajewskim znajdują się luźne kartki, na których zestawiał w uporządkowany sposób szykany, jakich doznawał od swojego przełożonego. 
oraz znakomitych opinii recenzentów ${ }^{10}$, przy przewlekłym postępowaniu, nie przyniosła zamierzonego skutku, gdyż w maju 1959 r. CKK odrzuciła wniosek $^{11}$. W tym stanie rzeczy ostatecznie dr. Henrykowi Grajewskiemu powierzono prowadzenie wykładów w Katedrze, której kuratorem został Jan Adamus ${ }^{12}$. Zainteresowany nie ustawał jednak w intensywnym prowadzeniu pracy naukowej, czego efektem było opublikowanie rozprawy Aleksander Napoleon Dybowski i jego projekt konstytucji dla Polski z 1848 r. (1959) i przeprowadzone na jej podstawie w 1961 r. kolokwium habilitacyjne $^{13}$. Umożliwiło to objęcie Katedry, którą faktycznie od czterech lat kierował i na czele której pozostał aż do śmierci. Nie była to jego jedyna funkcja organizacyjna.

Od początku pracy na Uczelni intensywnie zajmował się opieką nad studentami. Czynił to - jak wszystko - z ogromnym zaangażowaniem i talentem. Od 1951 r. aż do swych ostatnich chwil był opiekunem I roku. Prowadził godziny wychowawcze, pomagające studentom zaadaptować się w obcym dla licealistów środowisku. Uczył wszystkiego: regulaminu studiów, reguł studiowania i uczenia się, zasad dobrego wychowania, higieny i kultury osobistej, zasad odżywiania się i ubierania. Gromadził informacje o każdym studencie i wymagał tego od opiekunów grup. Uważał, że należy walczyć z zakorzenionym ciągle poglądem, że praca wychowawcza nie licuje z powaga prawdziwego uczonego, że przeszkadza mu w badaniach naukowych (1953 r.). Dopóki pozwalało mu zdrowie, był prodziekanem do spraw studenckich (1961-1964) ${ }^{14}$.

Wykłady przygotowywał starannie, na pierwszych godzinach niemal dyktując poszczególne kwestie, w miarę upływu czasu intensyfikował tempo wypowiedzi, wymuszając coraz większą aktywność studentów.

${ }^{10}$ Na recenzentów powołano profesorów Jana Adamusa, Wojciecha Hejnosza (Toruń) i Witolda Sawickiego (KUL). Trudno rozstrzygnąć, czy to reminiscencje konfliktu Grajewskiego ze Śreniowskim skłoniły referenta do zamieszczenia w opinii następującej uwagi: „Dr Grajewski jest - że tak to należy określić - bezpartyjnym komunista, który wszakże nie należy do partii: jest dobrze oczytany w literaturze ideologicznej..."

1129 maja 1959 r. CKK rozpatrując wniosek UŁ „uznała, że dotychczasowy dorobek naukowy w/w nie daje podstaw do przyznania mu wnioskowanego tytułu [naukowego docenta]". Można podejrzewać, że decyzja ta była skutkiem negatywnej opinii wyrabianej Grajewskiemu przez sekującego go kierownika Katedry, o czym pisał Adamus: „To co Śreniowski opowiadał o Grajewskim, było niesprawdzoną czasami fantazją [...] wpłynęło to na niektórych profesorów poza Łodzią u których zwiększyło to istniejące już bez tego, wspomniane wyżej uprzedzenia".

${ }^{12}$ Za opiekę tę zrewanżował się będąc kuratorem Katedry Powszechnej Historii Państwa i Prawa po śmierci Adamusa.

${ }^{13}$ Jednym z recenzentów był Józef Matuszewski, którego przejście do Łodzi zainicjował Grajewski. Obu historyków prawa rychło połączyła nie tylko zawodowa przyjaźń.

${ }^{14}$ W 1962/1963 r. - był członkiem Senackiej Komisji ds. Dydaktyczno-Wychowawczych, a od 1958 r. - członkiem Senackiej Komisji Bibliotecznej. 
Predylekcja do poszukiwań naukowych dominowała w jego postawie wobec życia, które nie szczędziło mu, związanych zwłaszcza ze zdrowiem, kłopotów. Jakby był przekonany, że poświęcenie się intensywnym poszukiwaniom naukowym, kontynuowanie ich w czasie choroby i uciążliwej terapii, wykorzystywanie zagranicznych wyjazdów leczniczych (Francja, Szwecja), by po zabiegach urwać parę chwil na przesiadywanie w bibliotekach i w archiwach, podejmowanie kolejnych tematów, to sui generis sposób na „wykręcenie się" od nieuniknionego. Z drugiej strony zdawał sobie też sprawę z tego, że pozostaje mu coraz mniej czasu i spieszył się z oddawaniem kolejnych studiów do druku.

Mimo szybko narastającego, poważnego dorobku ${ }^{15}$, miał kłopoty z dalszym awansem naukowym. Nominację profesorską (tytuł profesora nadzwyczajnego) otrzymał tuż przed śmiercią (5 lipca 1971 r.). Odebrać dyplomu już nie zdążył.

Łączył talent z codzienną sumiennością i odpowiedzialnością. Szybko uczył się języków, których znajomość była mu w danym momencie potrzebna. Znał języki włoski, szwedzki, hiszpański, czeski, bułgarski, białoruski, ukraiński i litewski. Biegle posługiwał się rosyjskim, francuskim, niemieckim i angielskim. Kolosalną jego pracowitość poznajemy nie tylko z listy prac, które zdążył opublikować, a znajdują się na niej zarówno studia z mediewistyki, czasów nowożytnych i okresu rozbiorów, jak i prace dotyczące prawa sądowego, zagadnień teorii prawa, kwestii doktryn i ideologii.

Bogactwo naukowej osobowości Henryka Grajewskiego poznajemy też z materiałów, których nie zdążył opracować do końca. Podziwu godna jest także rozległość jego zainteresowań: w papierach po zmarłym znaleźć można opracowane już w znacznym stopniu materiały, m.in. wyniki intensywnie prowadzonej kwerendy źródłowej do szeregu znaczących zagadnień $^{16}$. Grajewski przygotowywał kontynuację mediewistycznych studiów, m.in. nad prawem zwyczajowym ${ }^{17}$, gromadził też materiały do badań nad przysięgą funkcjonariuszy w Polsce szlacheckiej, równocześnie podejmując zagadnienia statusu prawnego więźniów politycznych

${ }^{15}$ Wyczerpująco przedstawił naukowe osiągnięcia Władysław Sobociński, Henryk Grajewski (1914-1971) (Szkic biograficzno-naukowy), CPH, 1973, t. XXV, z. 1, s. 235-240, oraz idem, Henryk Grajewski i jego wkład do historii nauki, „Kwartalnik Historii Nauki i Techniki” 1973, nr 18 (2), s. 333-340. Zob. też F. Bortkiewicz, Bibliografia opublikowanych prac naukowych Profesora Dra Habil. Henryka Grajewskiego, CPH, 1973, t. XXV, z. 1, s. 240-243.

16 Zwraca na to uwagę W. Sobociński, Henryk Grajewski (1914-1971)..., s. 238, przyp. 8 .

${ }_{17}$ Publikując już niektóre ustalenia, zob. Prawo zwyczajowe w „Leges seu statuta ac privilegia Regni Poloniae omnia” Jakuba Przyłuskiego, "Zeszyty Naukowe Uniwersytetu Łódzkiego" 1967, Nauki Humanistyczno-Społeczne, ser. I, z. 52, s. 113-153. 
i jego przestrzegania w praktyce II Rzeczypospolitej ${ }^{18}$. Obok kwestii prawa noszenia broni w Polsce szlacheckiej, przygotowywał się do badań nad normą prawną w ustawodawstwie I Rzeczypospolitej (m.in. nad zagadnieniem publikacji konstytucji i innych aktów prawodawstwa). Nie zamierzał przy tym rezygnować z prac nad tak dobrze przez siebie rozpoznanym wiekiem XIX. Tajemniczo przedstawia się sprawa monografii zatytułowanej Ustawodawstwo fabryczne Królestwa Kongresowego. Pracę tę, podjętą jeszcze pod auspicjami Stanisława Śreniowskiego, Henryk Grajewski doprowadził do końca, czy niemal do końca, po awansie na stanowisko adiunkta, ale nie opublikował jej, nawet fragmentarycznie, a w pozostałych po nim papierach nie ma po tym studium najmniejszego śladu: brakuje maszynopisu w jakiejkolwiek wersji, nie ma też $\mathrm{w}$ żadnej postaci materiałów przygotowawczych ${ }^{19}$.

Już przed habilitacją zaczął zapadać na zdrowiu. Początkowo błędnie diagnozowana choroba doprowadziła do usunięcia nerki. Walce o uratowanie drugiej poświęcał co roku okres wakacyjny. Wracał zza granicy zdrowszy, z nowymi materiałami, naładowany energią i zaraźliwym optymizmem. Choć zdawał sobie sprawę z powagi swojego stanu, nie opuszczał zajęć, nigdy nie odmawiał pomocy współpracownikom, szczerze przekonanym, że zna się na wszystkim. Wydawało się, że tak będzie zawsze.

Zmarł 12 grudnia 1971 r. Pochowany w Łodzi, na Cmentarzu Komunalnym Doły.

${ }_{18}$ Planowany tytuł Sytuacja więźniów politycznych w Polsce przedwrześniowej w świetle przepisów prawnych i praktyki.

${ }^{19}$ Jej istnienie obok deklaracji samego autora („Zebrałem już do tego materiał źródłowy i literaturę, a wstępne opracowanie genezy tego ustawodawstwa napisałem już i referowałem na seminarium Zespołu Katedr Historii Prawa UŁ" - pisał w 1953 r.), potwierdza w swojej ocenie prof. Adamus: „Praca ta, której powstawania byłem dość bliskim świadkiem i którą znam w rozmaitych fragmentach, jest wedle mnie bliska ukończenia [...] nie jest to już tylko przyczynek, ale obszerna monografia, która wymagała obszerniejszych poszukiwań, a ufunduje naszą wiedzę na tym odcinku na długie czasy". Równocześnie wskazuje, że po zakończeniu pracy Grajewski zniechęcił się do niej z jakiś ",subiektywnych" powodów. Natomiast w 1973 r. Władysław Sobociński jeszcze pisał: „Spora paczka materiałów dotyczących ustawodawstwa fabrycznego będzie z pewnością wykorzystana przede wszystkim ze względu na problematykę szczególnie aktualną w środowisku łódzkim” („Czasopismo Prawno-Historyczne” 1973, t. XXV, z. 1, s. 238, przyp. 8). 


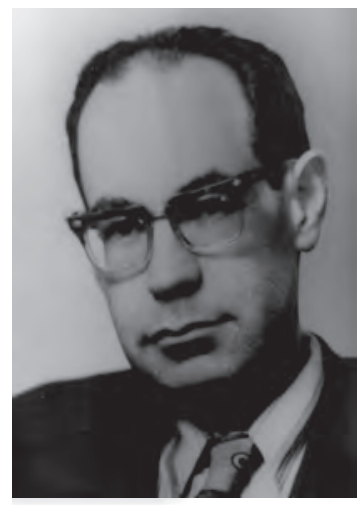

\section{Ireneusz Jakubowski, Anna Pikulska-Radomska, Zbigniew Rau}

\section{Jan Kodrębski (1936-1997)}

an Kodrębski związał się z Uniwersytetem Łódzkim w roku 1954, kie-
dy wstąpił na Wydział Prawa. Działalność naukową rozpoczął już na II roku studiów, zajmował się wtedy historią gospodarczą XIX w. pod kierunkiem prof. Stanisława Śreniowskiego. Jeszcze jako student związany był umową z Instytutem Historii PAN, ale etat asystenta uzyskał w roku 1958 w Katedrze Prawa Rzymskiego, gdzie pracował najpierw pod kierunkiem prof. Borysa Łapickiego, a potem prof. Cezarego Kunderewicza, przechodząc kolejne szczeble kariery akademickiej - w 1964 r. został adiunktem, a w 1975 docentem, w roku 1990 uzyskał tytuł profesora nadzwyczajnego, w 1992 - profesora zwyczajnego. Doktoryzował się niepublikowaną rozprawą o poglądach św. Augustyna na państwo i prawo rzymskie (1964), habilitował zaś pracą poświęconą klasycznej rzymskiej jurysprudencji Sabinianie i Prokulianie. Szkoły prawa w Rzymie wczesnego cesarstwa (Łódź 1974). Od roku 1982 kierował Katedrą Prawa Rzymskiego Uniwersytetu Łódzkiego.

Profesor utrzymywał aktywne kontakty z nauką światową. Był członkiem Société d'Histoire du Droit w Paryżu, brał udział, niejednokrotnie $\mathrm{w}$ charakterze referenta, $\mathrm{w}$ poważnych konferencjach i kongresach międzynarodowych skupiających romanistów, znawców antyku i historyków myśli nowożytnej. Za granicą był czynny także dydaktycznie; wykładał w uniwersytetach francuskich w Limoges, Paryżu (Paris I i Paris X), Nantes i Lyonie, jak również w uniwersytetach w San Sebastian i Rzymie. A językiem francuskim władał, warto dodać, po mistrzowsku, z najpiękniejszymi i najbardziej subtelnymi jego niuansami. Był także członkiem Komisji Praw Antycznych Komitetu Nauk o Kulturze Antycznej Polskiej Akademii Nauk, Komisji Historii Myśli Społecznej i Politycznej Polskiego Towarzystwa Historycznego i Łódzkiego Towarzystwa Naukowego. Współpracował z Komitetem Historii Nauki i Techniki PAN. Wypromował pięciu doktorów, dwoje z nich zostało samodzielnymi pracownikami naukowymi. 
Zmarł w Łodzi, 19 marca 1997 r. Dla najbliższych, przyjaciół i współpracowników śmierć ta oznaczała utratę człowieka wrażliwego i opiekuńczego, który do końca, także w ostatnich miesiącach długich cierpień, troszczył się o nich, wspierał radą inspirował do pracy. Spoczął na łódzkim cmentarzu na Dołach.

Praca o Sabinianach i Prokulianach, bardzo wysoko oceniona w Polsce, odbiła się echem także za granicą; dowodem uznania dla jej autora, poza przychylnymi recenzjami, może być choćby zaproszenie go do udziału w prestiżowym Aufstieg und Niedergang der römischen Welt i powierzenie mu opracowania rozdziału o nauczaniu prawa. W tomie zatytułowanym Recht, Methoden, Schulen, Einzelne Juristen wystąpił wespół z romanistami tej miary, jak m.in. W. Waldstein, F. Casavola, D. Liebs, H. Hausmaninger, A. Wacke, D. Nörr, G. Crifó. Udział w tym monumentalnym wydawnictwie świadczy dobitnie o ugruntowanej pozycji Jana Kodrębskiego w nauce światowej.

Horyzont badawczy Profesora w zakresie historii nauki prawa rzymskiego nie ograniczał się do antyku. Od czasów habilitacji objął swymi badaniami nowy obszar problemowy - historię nauki prawa rzymskiego w Polsce w czasach nowożytnych. Zwieńczeniem kilkunastoletnich badań stało się opublikowanie dużej miary monografii Prawo rzymskie w Polsce 94 XIX wieku (Łódź 1990). Praca ta, jak i wcześniejsze artykuły, znakomicie wypełniły lukę $\mathrm{w}$ badaniach nad recepcją prawa rzymskiego $\mathrm{w}$ Polsce. Jest bowiem swoistym paradoksem, że o ile dawniejsze dzieje tej recepcji, aż do epoki oświecenia, były przedmiotem zainteresowania polskich badaczy, to wiek XIX pozostawał w cieniu. Monografia, o której mowa, jest dziełem o szczególnych walorach. Oparta została na gruntownej znajomości literatury XIX-wiecznej i współczesnej, także tekstów niepublikowanych. Autor bowiem sięgnął do rękopisów: notatek, pamiętników, korespondencji. Jego erudycyjny warsztat doprowadził do powstania dzieła o poważnej wartości nie tylko naukowej, wyrażającej się całościowym i wnikliwym, a jednocześnie syntetycznym opracowaniem problematyki wcześniej bardzo słabo zbadanej, ale i zwyczajnie poznawczej - książka jest kopalnią fascynujących anegdot i ciekawostek.

Z czasem badania nad problematyką nowożytnej recepcji prawa rzymskiego Profesor przeniósł też na grunt zagadnień prawno-politycznych francuskiego oświecenia i rewolucji francuskiej. Badania te zwiastowały już podjęcie prac nad obszerną monografią, jaką zamierzał poświęcić tradycji prawa rzymskiego w nowożytnej myśli europejskiej, ze szczególnym uwzględnieniem liberalizmu i konserwatyzmu. Śmierć przerwała pracę nad tym dziełem.

W kręgach specjalistów Jan Kodrębski znany był, ze względu na swój niekwestionowany dorobek naukowy $\mathrm{w}$ tej dziedzinie, jako prawnik- 
-romanista. W środowisku łódzkim natomiast utożsamiany był zawsze przede wszystkim z historią doktryn politycznych i prawnych. Oryginalną nieprzeciętną osobowość Profesora na Uniwersytecie Łódzkim łączono nierozerwalnie właśnie z jego wykładami z doktryn, które pozwalały mu na zademonstrowanie imponującej erudycji połączonej z niespotykanym kunsztem dydaktycznym. Blisko trzy dziesięciolecia jego wykładów (1969-1996) z doktryn na studiach prawniczych i administracyjnych dla wielu roczników studentów stanowiły szkołę nie tylko wiedzy o dorobku zachodniej myśli politycznej, ale też, a może przede wszystkim, inspirację i motywację do autorskiego, studenckiego interpretowania ówczesnego świata zjawisk społecznych. Dziś stosunkowo łatwo wskazać klucz do takiego, najprawdopodobniej świadomego i celowego, traktowania przez niego tej dyscypliny. Klucz ten stanowią jego własne doświadczenia, które Profesor zdecydował się upublicznić dopiero na kilka miesięcy przed śmiercią. Składają się one na dramatyczna, często głęboko tragiczną biografię, niezwykle wyraziście oddającą piętno, jakie wiek XX odcisnął na naszej części świata ${ }^{1}$.

Pochodził ze zasymilowanej żydowskiej rodziny Szpilfoglów. Jej członkowie studiowali na europejskich uczelniach, zdobywając przede wszystkim dyplomy inżynierskie. Absolwentem francuskiej politechniki, inżynierem chemikiem i udziałowcem rodowej fortuny był także ojciec Profesora Markus Szpilfogiel, matka zaś, Rajzla Dawidowicz pochodziła z rodziny częstochowskich przemysłowców branży metalurgicznej oraz wapienniczej i legitymowała się uniwersyteckim wykształceniem ekonomicznym zdobytym w Wiedniu.

Wraz z wybuchem drugiej wojny światowej rodzina została rozdzielona, gdyż ojciec Profesora wraz z braćmi znalazł się na ziemiach zajętych przez Armię Czerwoną. Sam ocalał dzięki wywiezieniu na Syberię, jego trzej bracia zaś zostali zamordowani przez hitlerowców po $1941 \mathrm{r}$. Jan z matką przeniósł się do Częstochowy, gdzie z jej rodziną trafił do getta. Po pewnym czasie chrześcijańskiej rodzinie żony jego wuja udało się przeprowadzić na stronę aryjską kolejno - samego wuja, potem chłopca i wreszcie jego matkę. Pozostała część bardzo licznej, wielopokoleniowej rodziny po likwidacji getta zginęła w Treblince. Przez prawie trzy lata

${ }^{1}$ Ze świadectwa profesora Jana Kodrębskiego, Łódź 2009. Książka ta, wydana przez Katedrę Prawa Rzymskiego Uniwersytetu Łódzkiego oraz Centrum Badań Żydowskich, zawiera m.in. wywiad z Profesorem przeprowadzony przez Joannę Wiszniewicz 1 czerwca 1996 r., wykonany na zlecenie USC Shoah Foundation Institute oraz artykuł Jacka Walickiego, Kilka słów o rodzinie Szpilfoglów-Kodrębskich i młodych latach Jana Kodrębskiego. Zob. też A. Pikulska-Radomska w: Sylwetki łódzkich uczonych. Profesor Jan Kodrębski, z. 89, Łódź 2008 i Z. Rau, Wspomnienie o Janie Kodrębskim, [W:] M. Maciejewski, M. Marszał, M. Sadowski (red.), Tendencje rozwojowe myśli politycznej i prawnej, Wrocław 2014, s. 51-57. 
ukrywał się - czasem z matką, czasem pod opieką bliższej i dalszej chrześcijańskiej rodziny oraz znajomych - w Częstochowie i okolicach.

Koniec wojny przyniósł połączenie rodziny. Ojciec Profesora powrócił jako oficer II Armii Ludowego Wojska Polskiego i został służbowo przeniesiony na Ziemie Zachodnie. Państwo Kodrębscy (rodzice Profesora zdecydowali się na zmianę nazwiska, nawiązując do nazwy majątku Kodręb koło Radomska, który w wieku XIX przejściowo znajdował się w posiadaniu przodka Josela Szpilfogla) zamieszkali w Jeleniej Górze. Stąd też wysłali syna na dwuletni pobyt u rodziny w Genewie, gdzie poddany został leczeniu ortopedycznemu, które jednak nie zdołało zapobiec jego kalectwu. Z elitarnej, międzynarodowej szkoły w Genewie powrócił do liceum w Jeleniej Górze i rzucił się w wir prac różnych ówczesnych organizacji młodzieżowych. Dzięki temu uzyskał znakomitą rekomendację na studia na Uniwersytecie Łódzkim. Jak wspominał, $\mathrm{w}$ środowisku akademickim nigdy nie spotkał się z oznakami antysemityzmu. Przypominał sobie, że rodzice od końca wojny rozważali wyjazd z Polski, nigdy się jednak nań nie mogli zdecydować. Po roku 1968 nie zdecydował się na to także Profesor. Przyznawał, iż za granicą w kontaktach ze środowiskami żydowskimi spotykał się z niezrozumieniem, a nawet ostracyzmem, gdy argumentował, że można być Żydem i miesz96 kać w Polsce.

Nie jest przypadkiem, że właśnie po wydarzeniach marcowych Jan Kodrębski, jako młody adiunkt, zdecydował się poprosić wybitnego teoretyka prawa, profesora Jerzego Wróblewskiego, o przekazanie mu wykładów z doktryn polityczno-prawnych. Profesor Wróblewski uczynił to z pewną ulga gdyż stojąc twardo na gruncie pozytywizmu prawniczego, nie czerpał szczególnej satysfakcji z ich nauczania. Natomiast dla dr. Kodrębskiego wykład ten stanowił bardzo pożądaną formę wyrazu jego intelektualnego credo. Wyrażał zatem imperatyw poznania maksymalnie szerokiego spektrum doktryn, tak historycznego (stąd rozszerzenie problematyki wykładu na doktryny starożytne i średniowieczne, które prof. Wróblewski dotąd pomijał), jak i - przede wszystkim - ideowego, ze szczególnym uwzględnieniem tych stanowiących radykalną alternatywę dla ówczesnej oficjalnej doktryny marksizmu-leninizmu. Wykładając, komunikował się ze swoimi słuchaczami korzystając $\mathrm{z}$ analogii, ironii, sarkazmu, a więc środków, które ówczesna polska inteligencja wprowadzała do publicznego dyskursu, by próbować opisywać dominującą rzeczywistość. Ta postawa zapewniła mu niezwykłą osobistą popularność wśród studentów, uczyniła bohaterem niezliczonych dykteryjek, anegdot, legend akademickich, pozycjonując go jako jedną z najbarwniejszych (a może najbarwniejszą) postaci Wydziału Prawa i Administracji. Samej zaś dyscyplinie doktryn polityczno-prawnych nadała status przedmiotu, 
który w przeciwieństwie do dalekich wówczas od dynamizmu dogmatyk prawniczych cechowała świeżość i niekonwencjonalność założeń oraz możliwość wielorakich interpretacji.

Jego seminaria cieszyły się, szczególnie u schyłku lat siedemdziesiątych i w latach osiemdziesiątych, niezmienną popularnością, każdy bowiem ich uczestnik, niezależnie od prezentowanej przez siebie postawy światopoglądowej i opcji politycznej, mógł liczyć na swobodę dyskusji, wyrozumiałość i dyskretną pomoc $\mathrm{w}$ nadaniu swoim przemyśleniom profesjonalnego, akademickiego charakteru. Zgłębiano tam zagadnienia katolickiej nauki społecznej i socjalizmu, liberalizmu i konserwatyzmu, myśli Dmowskiego i Piłsudskiego. Sam Profesor starannie unikał dzielenia się własnymi preferencjami ideowymi, dbając tylko o to, by atmosfera seminarium była bliska ideom, które - zwłaszcza pod koniec życia - były mu szczególnie bliskie: społeczeństwa otwartego i pluralizmu wartości. Otoczony przez całe lata gronem seminarzystów i współpracowników, Profesor nie stworzył jednak własnej szkoły ani w dziedzinie prawa rzymskiego, ani historii doktryn polityczno-prawnych. To cena, jaką zapłacił za swobodę wyboru przedmiotu zainteresowań i dyskusji, jaką nam wszystkim dawał.

Pozostawało mu zatem służyć współpracownikom swoją wiedzą i doświadczeniem akademickim. Ale także zwykłą ludzką uczynnością. Wynikało to najprawdopodobniej z jego postrzegania Uniwersytetu jako naturalnej wręcz wspólnoty, której członkowie złączeni są oczywistymi, egzystencjalnymi więzami, daleko wykraczającymi poza sferę zawodowych obowiązków czy intelektualnych dociekań. Jego drugim domem była biblioteka uniwersytecka, w której bywał codziennie, przynajmniej raz. Prawie codziennie też znajdował w niej tytuły pozycji, które, jak sądził, mogą okazać się użyteczne w pracy jego współpracowników, także magistrantów. Wielokrotnie wspomagał swoją radą i wpływami szeregowych pracowników uczelni, angażując się w rozwiązywanie ich bytowych problemów, szczególnie dotyczyło to uniwersyteckich bibliotekarzy, którzy zwracali się doń po wsparcie jako do wieloletniego przewodniczącego uczelnianej rady bibliotecznej. Bliższym współpracownikom czuł się zobowiązany proponować pożyczkę, kiedy przypuszczał, iż mogą mieć kłopoty finansowe. Czasami taka uczelniana uczynność wymagała nie tylko empatii, ale też odwagi. Kiedy w roku 1981 na Wydziale Dziekanem wybrano przy wsparciu Solidarności prof. Birutę Lewaszkiewicz-Petrykowska, ta zaproponowała, mimo różnic ideowych, miejsce w swoim kolegium doc. Kodrębskiemu. Jak dziś powtarza, w tej sprawie miała dobrą intuicję. Po wprowadzeniu stanu wojennego, gdy wydziałowa komisja weryfikacyjna przygotowywała się do pozbawienia pracy pięciu adiunktów, w wielogodzinnej konfrontacji z nią prof. Lewaszkiewicz-Petrykowska 
mogła liczyć tylko na aktywne wsparcie doc. Kodrębskiego. Adiunkci pozostali na Wydziale².

Pamięć o Profesorze nadal łączy pracowników Wydziału. Została też zinstytucjonalizowana przez powołanie Kapituły Nagrody im. Jana Kodrębskiego, przyznawanej rokrocznie za najlepszą pracę magisterską napisaną na Wydziale Prawa i Administracji Uniwersytetu Łódzkiego ${ }^{3}$.

${ }^{2}$ Informacje o tych faktach pochodzą z licznych rozmów prowadzonych przez autorów z prof. dr hab. Birutą Lewaszkiewicz-Petrykowską.

${ }^{3}$ Członkami Kapituły są profesorowie Wydziału reprezentujący wiodące dyscypliny prawnicze. Wysokość nagrody wynosi 1000 euro i jest fundowana przez Grupę Wydawniczą Polskapresse oraz Narodowe Centrum Kultury. 


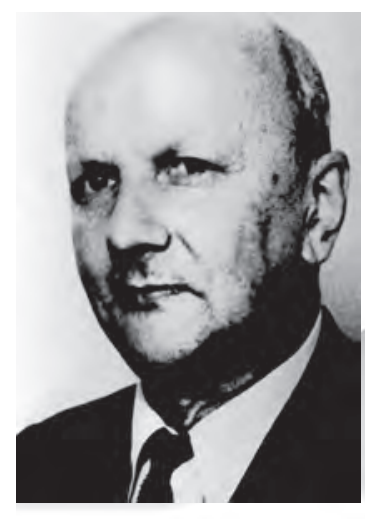

Tomasz A. J. Banyś, Łukasz Jan Korporowicz

\section{Cezary Kunderewicz (1912-1990)}

$\mathcal{U} \begin{aligned} & \text { rodził się w Kijowie } 23 \text { czerwca } 1912 \text { r. w polskiej rodzinie mieszczań- } \\ & \text { skiej }{ }^{1} \text {. Zaledwie kilka lat później, w związku z wybuchem pierwszej }\end{aligned}$ wojny światowej, a następnie rewolucji październikowej, C. Kunderewicz został wysłany do Warszawy, z którą związał się życiowo aż do swojej śmierci. Dzięki zdobywanej już od wczesnych lat życia wiedzy, jeszcze w okresie uczęszczania do szkoły średniej udzielał korepetycji, z których się utrzymywał. W roku 1931 ukończył Gimnazjum im. Tadeusza Reytana i podjął studia z zakresu filozofii na Uniwersytecie Warszawskim. Wraz z kolejnym rokiem akademickim zmienił jednak obiekt swoich zainteresowań i przeniósł się na Wydział Prawa UW. Studia te ukończył w roku 1936. Podobnie jak w okresie wcześniejszym, zmuszony był do utrzymywania się z korepetycji. Zdaniem J. Kodrębskiego, już w tym okresie C. Kunderewicz cechował się przymiotami, które charakteryzowały go przez całe jego dorosłe życie: „pracowitość, wytrwałość, systematyczność i miłość wiedzy ${ }^{2 \prime \prime}$.

Po ukończeniu studiów trudna sytuacja materialna Cezarego Kunderewicza zmusiła go najpierw do zarejestrowania się jako bezrobotny, następnie zaś do przyjęcia posady rachmistrza na budowie. To ostatnie

${ }^{1}$ Na temat postaci prof. Cezarego Kunderewicza do tej pory powstały następujące opracowania: J. Kodrębski, Césaire Kunderewicz, „Revue historique de droit français et étranger" 1991, 69.1, s. 136-137 oraz idem, Cezary Kunderewicz (1912-1990), „Czasopismo Prawno-Historyczne" 1994, nr 46, s. 179-187. Ponadto w roku 1986, z okazji siedemdziesiątych urodzin oraz czterdziestopięciolecia pracy naukowej, Cezaremu Kunderewiczowi dedykowano tom XXI „Acta Universitatis Lodziensis”. Folia Iuridica, ss. 196. Już zaś pośmiertnie, w roku 1991, wydano wybór prac Profesora zatytułowany Studia z rzymskiego prawa administracyjnego, Łódź 1991, ss. 145. Tam też J. Kodrębski przedstawił sylwetkę C. Kunderewicza (s. 5-6). W tomie XVII „Studia Iuridica” odnaleźć można z kolei wspomnienia samego C. Kunderewicza dotyczące okresu jego studiów na Wydziale Prawa UW („Studia Iuridica” 1989, nr 17, s. 103-109).

${ }^{2}$ J. Kodrębski, Cezary Kunderewicz..., s. 179. 
umożliwiło mu podjęcie studiów doktoranckich oraz bezpłatnej aplikacji sądowej. Od roku 1938 do wybuchu wojny pracował również jako referent prawny w Rektoracie UW.

Na swojego opiekuna naukowego C. Kunderewicz wybrał wykładowcę historii filozofii prawa Eugeniusza Jarrę. Znacząca część pracy doktorskiej przygotowana została jednak pod kierunkiem dr. Henryka Piętki - adiunkta w katedrze profesora E. Jarry ${ }^{3}$. Tematem rozprawy ukończonej w roku 1939 były poglądy filozoficzno-prawne Łukasza Opalińskiego. Praca została opublikowana jako ostatnia z serii Prac Seminarium Filozofii Prawa Uniwersytetu Józefa Piłsudskiego w Warszawie, co nastąpiło w dniu 1 września 1939 r. Profesor Kunderewicz wspominał potem, że gotowy nakład odbierał z drukarni już w trakcie bombardowania Warszawy ${ }^{4}$. Zdaniem J. Kodrębskiego stopień doktora przyznany został C. Kunderewiczowi jeszcze w czerwcu 1939 r. ${ }^{5}$, jednak z relacji samego profesora Kunderewicza wynika, że formalnie stopień ten został mu nadany w listopadzie roku $1945^{6}$.

W trakcie drugiej wojny światowej C. Kunderewicz pozostał zatrudniony $\mathrm{w}$ administracji uniwersyteckiej jako p.o. sekretarza uczelni, które to stanowisko sprawował do roku 1941, gdy został z niego usunięty przez władze okupacyjne. Jednocześnie nie zaprzestał pracy naukowej. W tym 100 okresie przygotował rozprawę naukową na temat filozofii politycznej Niccolo Machiavellego. Jak wiele innych prac naukowych, również ta została zniszczona podczas powstania warszawskiego ${ }^{7}$.

Wraz z trwaniem wojny sytuacja C. Kunderewicza pogarszała się. Po doświadczeniach Powstania Warszawskiego trafił do obozu w Pruszkowie, następnie skierowany został do prac przymusowych, by ostatecznie trafić do obozu koncentracyjnego w Oświęcimiu.

Okres powojenny okazał się dla Cezarego Kunderewicza niezwykle wymagający. W tym czasie łączył pracę $\mathrm{w}$ administracji uniwersyteckiej z pracą naukowo-dydaktyczną. W administracji odbudowywanego Uniwersytetu Warszawskiego, zdaniem J. Kodrębskiego, C. Kunderewicz odgrywał rolę wiodąca, jako jeden z najbliższych współpracowników rektora Stefana Pieńkowskiego, piastując jednocześnie szereg stanowisk admini-

${ }^{3}$ C. Kunderewicz, 1932-1939, „Studia Iuridica” 1989, nr 17, s. 107. Na temat postaci profesora Eugeniusza Jarry zob. T. Kozłowski, Eugeniusz Jarra, 1881-1973, [w:] G. Bałtruszajtys (red.), Profesorowie Wydziału Prawa i Administracji Uniwersytetu Warszawskiego 18082008, Warszawa 2008, s. 109-111.

${ }^{4}$ C. Kunderewicz, 1932-1939..., s. 108.

${ }^{5}$ J. Kodrębski, Cezary Kunderewicz..., s. 180.

6 C. Kunderewicz, 1932-1939..., s. 108.

7 J. Kodrębski, Cezary Kunderewicz..., s. 181.

${ }^{8}$ Ibidem, s. 182. 
stracyjnych. Dodatkowo zatrudniony został jako starszy asystent w Katedrze Historii Prawa na Zachodzie Europy. Do roku 1947 katedra pozostawała jednak nieobsadzona, co spowodowało, że to C. Kunderewicz prowadził wszystkie zajęcia oraz organizował jej zaplecze materialno-naukowe. Mimo to udawało mu się znaleźć czas na kontynuację badań, których efektem było przygotowanie rozprawy (docelowo mającej być pracą habilitacyjną) zatytułowanej Elementy ustrojowe w polityce Bossueta. Pomimo oddania jej do druku w roku 1949, dwa lata później praca została zwrócona z adnotacją Ministerstwa Szkół Wyższych i Nauki o niedopuszczeniu do publikacji. Jak podkreśla J. Kodrębski, oznaczało to niemożność przeprowadzenia na jej podstawie postępowania habilitacyjnego. Jednocześnie ze względów politycznych Cezarego Kunderewicza zmuszono do odejścia z pracy na Wydziale Prawa. Pozwolono mu jedynie zachować dotychczasowe stanowisko w strukturze administracji uczelnianej ${ }^{10}$.

Mając zatem niemal czterdzieści lat, C. Kunderewicz został zmuszony do bezpowrotnego porzucenia dotychczasowych zainteresowań naukowych. Będąc jednak naukowcem z powołania, podjął współpracę z Rafałem Taubenschlagiem ${ }^{11}$, który, dostrzegając jego potencjał, umożliwił mu ponowne rozpoczęcie kariery naukowej, a w roku 1954 zatrudnił go w Katedrze Prawa Antycznego UW na stanowisku adiunkta. Po śmierci R. Taubenschlaga w roku 1958, C. Kunderewicz przedstawił rozprawę habilitacyjna, która jednak w związku z narzuceniem w tamtym czasie polskim uniwersytetom radzieckiego systemu stopni naukowych, została uznana jedynie za rozprawę doktorską. Tym samym przedwojenną pracę poświęconą Ł. Opalińskiemu uznano za dysertację na pośredni stopień kandydata nauk. Wydaje się, że wpływ na to mogły mieć kontakty C. Kunderewicza z E. Jarra, który uważany był za przedstawiciela skrajnej prawicy, a w omawianym okresie był jedną z czołowych postaci polskiej inteligencji na emigracji.

Cezary Kunderewicz wykazał niezłomną postawę i już w roku 1960 przedstawił zupełnie nową rozprawę habilitacyjną na temat odpowiedzialności urzędników w starożytnym Egipcie, która została przez ówczesnych recenzentów bardzo wysoko oceniona. Po przeprowadzeniu postępowania C. Kunderewicz otrzymał stopień docenta, jednak nie spowodowało to jego awansu w strukturze uczelni. Dlatego też przyjął otrzymaną w roku 1961 propozycję objęcia po profesorze Borysie Łapickim

${ }^{9}$ Ibidem.

10 Ibidem, s. 182-183.

${ }^{11}$ Na temat R. Taubenschlaga zob. m.in. J. Sondel, Rafat Taubenschlag. Romanista, papirologo, stolico del diritto polacco, [w:] M. Zabłocka, J. Krzynówek, J. Urbanik, Z. Służewska (red.), Au-delà des frontières. Mélanges de droit romain offerts à Witold Wołodkiewicz, t. II, Warszawa 2000, s. 933-954. 
Katedry Prawa Rzymskiego na Uniwersytecie Łódzkim. Mimo to przez lata zachował bliskie więzi ze swoją dawną Katedrą. Wymownym tego dowodem był fakt, że do końca życia przyjeżdżał na warszawski Wydział Prawa i pracował przy biurku swojego dawnego mistrza - prof. R. Taubenschlaga.

Wkrótce po zatrudnieniu, w roku 1966, władze Uniwersytetu Łódzkiego wystąpiły o przyznanie C. Kunderewiczowi tytułu profesora nadzwyczajnego. Podobnie jak na wcześniejszych etapach kariery, także i tym razem wniosek ze względów politycznych został odrzucony. Ostatecznie tytuł profesora nadzwyczajnego przyznano Cezarmu Kunderewiczowi w roku 1971, natomiast profesora zwyczajnego w roku 1976. Na emeryturę C. Kunderewicz przeszedł w roku 1982 pozostawiając kierownictwo Katedry Janowi Kodrębskiemu.

Dorobek naukowy C. Kunderewicza jest bardzo różnorodny, co wynika między innymi ze wspomnianych już trudności, które napotkał na swojej drodze życiowej. Wczesne prace poświęcone zostały zagadnieniom z zakresu historii filozofii prawa - była to jego rozprawa doktorska o poglądach Łukasza Opalińskiego oraz zatrzymana przez cenzurę habilitacja poświęcona myśli Jacques-Bénigne Bossueta. Z okresem kierowania Katedrą Historii Prawa na Zachodzie Europy UW wiąże się praca C. Kunderewicza na temat polskiego procesu granicznego, która ukazała się z pewnym opóźnieniem ${ }^{12}$. Późniejsze swoje badania Cezary Kunderewicz poświęcił tematyce praw starożytnych. Początkowo, pod wpływem R. Taubenschlaga, zajął się prawem ptolemejskiego Egiptu ${ }^{13}$. Dzięki kontaktom z czeskim asyrologiem J. Klimą, zwrócił z kolei uwagę na problematykę historii praw starożytnego Wschodu, to jest tzw. praw klinowych, zapoczątkowując tym samym badania nad nimi w Polsce. Łącznie opublikował kilkanaście prac poświęconych tej tematyce ${ }^{14}$. W tym zakresie, jak również $\mathrm{w}$ dziedzinie

${ }^{12}$ C. Kunderewicz, Dzieła Stanisława Łochowskiego i Marcina Paciorkowskiego o polskim procesie granicznym, Warszawa 1956, ss. 57.

${ }^{13}$ Do najważniejszych z nich należą: C. Kunderewicz, The problem of anefang in certain ancien and medieval laws, "The Journal of Juristic Papyrology" 1956, No 9-10, s. 401-430; idem, Evolution historique de la responsabilité des fonctionaires dans l'Égypte ptolemëque. (Symbolae Raphaeli Taubenschlag dedicatae), „Eos” 1957, vol. 48, fasc. 2, s. 101-115; idem, Evolution historique de la responsabilité des fonctionaires dans l'Égypte ptolemë̈que, II partie, „Revue internationale des droits de l'antiquité" 1957, no 4, s. 167-217.

${ }^{14}$ Do najważniejszych z nich należą: C. Kunderewicz, Kodeks Ur-Nammu, „Czasopismo Prawno-Historyczne" [dalej: CPH] 1958, t. X, z. 2, s. 9-18; idem, Kodeks Lipit-Isztara, CPH, 1959, t. XI, z. 2, s. 27-43; idem, Reformy Urukaginy władcy Lagasza, CPH, 1964, t. XVI, z. 1, s. 89-102; idem, Zbiór praw z Esznuny, CPH, 1966, t. XVIII, z. 1, s. 9-29; idem, Fragmenty nieznanych sumeryjskich zbiorów prawa, CPH, 1968, t. XX, z. 1, s. 9-16; idem, Nowe fragmenty sumeryjskich zbiorów prawnych, CPH, 1969, t. XXI, z. 2, s. 1-12; idem, Najstarsze prawa świata, wyd. 1, Łódź 1972; wyd. 2 popr. i uzup., Łódź 1990. 
papirologii prawniczej, czyli historii prawa ptolomejskiego i rzymskiego Egiptu stał się niekwestionowanym, światowej miary autorytetem. Najpóźniej C. Kunderewicz zajął się rzymskim prawem publicznym. Tu również był prekursorem na gruncie polskiej romanistyki ${ }^{15}$.

Obok pracy naukowej, C. Kunderewicz był autorem wielu cennych tłumaczeń zarówno współczesnej literatury naukowej, jak i źródeł prawa. Szczególnie te drugie przyniosły mu uznanie ekspertów. Cezary Kunderewicz jest autorem tłumaczenia Instytucji Gaiusa, wydanego w roku 1982 oraz Instytucji Justyniana opublikowanego w roku 1986. Były to pierwsze nowoczesne translacje tych dwóch pomników prawa rzymskiego dostępne dla polskiego czytelnika ${ }^{16}$. Ponadto był autorem polskiego przekładu dzieła rzymskiego mierniczego Frontinusa zatytułowanego $O$ akweduktach miasta Rzymu, które ukazało się w roku 1961. Badania prowadzone nad tym starożytnym dziełem zwróciły uwage nauki zagranicznej. W roku 1973 w prestiżowej serii Bibliotheca Teubneriana ukazała się nowa edycja tekstu Frontinusa opatrzona komentarzami autorstwa C. Kunderewicza. W przekonaniu J. Kodrębskiego ,,jest to editio maior z samodzielnym i nowatorskim ustaleniem tekstu, które z pewnością pozostanie w obiegu naukowym długo, stanowiąc dowód wysokich kwalifikacji filologicznych wydawcy"17.

Trzecim polem działalności twórczej C. Kunderewicza były opracowania dydaktyczne. Pierwsze opublikował już w roku 1949 na potrzeby studentów historii państwa i prawa Uniwersytetu Warszawskiego ${ }^{18}$. Dalsze prace były już poświęcone prawu rzymskiemu. Były to skrypty, których ostatnie, piąte wydanie ukazało się już po śmierci autora w roku $1995^{19}$, oraz wybór źródeł do ćwiczeń z rzymskiego prawa prywatnego ${ }^{20}$.

${ }^{15}$ Por. m.in. C. Kunderewicz, Ochrona zabytków architektury w Kodeksie Teodozjańskim, "Archeologia" 1966, t. XVII, s. 80-88; idem, Le gouvernement et les etudiants dans le Code Theodosien, "Revue Historique de Droit Francis et Etranger" 1972, t. L, no 4, s. 575-588; idem, Prawo budowlane starożytnego Egiptu (1), CPH, 1977, t. XXIX, z. 2, s. 91-115; idem, Prawo budowlane starożytnego Egiptu (II), CPH, 1979, t. XXXI, z. 1, s. 53-74; idem, Ochrona środowiska naturalnego w prawie rzymskim, CPH, 1981, t. XXXIII, z. 2, s. 1-10; idem, Studia z rzymskiego prawa administracyjnego, Łódź 1991.

${ }_{16}$ Fragmentaryczne tłumaczenia z wieku XIX były już trudne do zdobycia, a ponadto nie odpowiadały nowoczesnym standardom naukowym.

17 J. Kodrębski, Cezary Kunderewicz..., s. 186.

${ }^{18}$ C. Kunderewicz, Wybór tekstów tacińskich do ćwiczeń z powszechnej historii państwa i prawa, Warszawa 1949, ss. 41.

${ }^{19}$ C. Kunderewicz, Wstęp do nauki rzymskiego prawa prywatnego, wyd. 1, Łódź 1965; wyd. 2, Łódź 1967; idem, Instytucje prawa rzymskiego w krótkim zarysie, cz. 1, Łódź 1978; cz. 2, Łódź 1981; idem, Rzymskie prawo prywatne, wyd. 1, Łódź 1982; wyd. 2, Łódź 1995.

${ }^{20}$ C. Kunderewicz, Wybór źródet do ćwiczeń z rzymskiego prawa prywatnego, wyd. 1, Łódź 1970; wyd. 2, Łódź 1977. 
O pozycji naukowej C. Kunderewicza może świadczyć fakt, że Z. Rymaszewski nie waha się określić go słowem „wybitny”, a każdorazowo $\mathrm{w}$ postępowaniu awansowym prace i dorobek profesora spotykały się z najwyższą oceną ${ }^{21}$.

Warto zauważyć, że częściową kontynuatorką zainteresowań C. Kunderewicza była jego córka, s. dr Teresa Kunderewicz, CR ${ }^{22}$.

Profesor Cezary Kunderewicz był bardzo życzliwy wobec studentów. Był dla nich jednak wymagającym egzaminatorem, choć z powodu wspomnianej życzliwości niekiedy studentom podpowiadał. Swoich współpracowników traktował z taktem i wyrozumiałością. Doświadczenia życiowe spowodowały, że pozostawał raczej zamknięty w sobie, skryty i nie miał naprawdę bliskich przyjaciół. Jego życie koncentrowało się wokół pracy naukowej prowadzonej w Warszawie oraz obowiązków dydaktycznych w Łodzi. Niezwykle dbał o księgozbiór Katedry, troszczył się o jego rozbudowę, a niekiedy bywał nawet „przyłapywany” przez swoich współpracowników na odkurzaniu książek.

W pracy naukowej unikał formułowania śmiałych tez, był natomiast, jak pisze J. Kodrębski, niezwykle sumienny i staranny w prowadzonych przez siebie analizach ${ }^{23}$. Profesor Kunderewicz miał olbrzymią wiedzę na temat literatury starożytnej ${ }^{24}$. Jego majątek składał się głównie z książek, 104 które zajmowały całe jego niewielkie mieszkanie.

Cezary Kunderewicz zmarł 20 sierpnia 1990 r. w swoim warszawskim mieszkaniu. Pochowany został na Cmentarzu Powązkowskim.

${ }^{21}$ J. Kodrębski, Cezary Kunderewicz..., s. 184, 185, 187.

${ }_{22}$ T. Kunderewicz, Geneza opieki kobiety nad dziećmi w prawie rzymskim, „Prawo Kanoniczne" 1980, 23.3-4, s. 287-297 i idem, Disposizioni testamentarie e donazioni a scopo di beneficenza nel diritto giustinianeo, "Studia et documenta historiae et iuri” 1984, t. XLVII, s. 47-92.

${ }^{23}$ J. Kodrębski, Cezary Kunderewicz..., s. 187.

${ }^{24}$ Ireneusz Jakubowski wspomina następującą anegdotę: pewnego razu zorientował się, że wewnętrzna strona okładki jednego ze starodruków znajdujących się w Katedrze wyklejona została fragmentami innego dzieła. Pochodzenia tych fragmentów nie był jednak w stanie ustalić. Zagadnął o to profesora Kunderewicza, który przyjrzał się zagadkowym fragmentom, a następnie w dość krótkim czasie podał dokładne pochodzenie cytatów. 


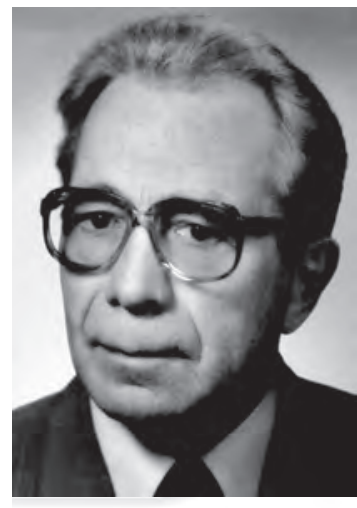

Zbigniew Góral

\section{Henryk Lewandowski $(1933-2013)^{1}$}

Profesor Henryk Lewandowski całe swoje życie akademickie związał $\int$ z Łodzią i Uniwersytetem Łódzkim. Studia magisterskie na Wydziale Prawa ukończył w 1957 r. Po odbyciu aplikacji i asesurze, w 1959 r. podjął pracę w Katedrze Prawa Pracy UŁ, początkowo na pół etatu (łączył wówczas pracę naukową z pełnieniem funkcji sędziego), a od $1961 \mathrm{r}$. w pełnym wymiarze czasu pracy. Wszystkie etapy jego kariery akademickiej były związane z macierzystą uczelnią. Pracę doktorską obronił w 1965 r. (na podstawie rozprawy pt. Instytucja próby w prawie stosunku pracy) stopień naukowy doktora habilitowanego uzyskał w 1974 r. (przedstawiając rozprawę pt. Uprawnienia kierownicze w stosunku pracy), w 1986 r. został profesorem nadzwyczajnym, a w $1990 \mathrm{r}$. nadano mu tytuł profesora zwyczajnego. Do końca życia był wierny Katedrze Prawa Pracy, to było najważniejsze miejsce jego aktywności naukowej. Katedrą kierował od 1982 aż do 2004 r. Później, już jako profesor emerytowany, kontynuował w Katedrze swoją działalność naukowo-dydaktyczna, nadal prowadząc wykłady i seminaria doktoranckie. $\mathrm{W}$ okresie pracy $\mathrm{w}$ Uniwersytecie Łódzkim przejawiał wielką aktywność w sferze organizacyjnej. Kierował przez cztery lata Studium Zaocznym Prawa, a w latach 1987-1990 piastował stanowisko dziekana Wydziału Prawa i Administracji. Należał do licznych organizacji, m.in. do Sekcji Polskiej Międzynarodowego Stowarzyszenia Prawa Pracy i Zabezpieczenia Społecznego, do Association Henri Capitant des Amis de la Culture Juridiqe Française, był też członkiem Komitetu Nauk Prawnych PAN, pełnił również funkcję stałego konsultanta Głównej Inspekcji Pracy. Za swoją działalność otrzymał wiele nagród, medali i odznaczeń.

${ }^{1} \mathrm{~W}$ przygotowaniu biogramu zostały wykorzystane m.in. następujące opracowania: Z. Góral, Słowo o Jubilacie, [w:] Z zagadnień współczesnego prawa pracy. Księga jubileuszowa Profesora Henryka Lewandowskiego, Warszawa 2009 oraz idem, Wspomnienie o Profesorze Henryku Lewandowskim (1933-2013), „Praca i Zabezpieczenie Społeczne” 2013, nr 12. 
Głównym obszarem zainteresowań naukowych Profesora Henryka Lewandowskiego były zagadnienia prawa pracy. Jego dokonania naukowe (ponad 200 różnego rodzaju opracowań) sprawiły, że znalazł się w gronie największych specjalistów polskiego prawa pracy, znanym zresztą także poza granicami naszego kraju. W początkowym okresie skoncentrował uwagę na kwestiach dotyczących nawiązania stosunku pracy. Znalazło to wyraz już w rozprawie doktorskiej, poświęconej instytucji próby w prawie pracy. Wydana w 1968 r. monografia podoktorska stanowiła przedsięwzięcie o pionierskim, w tamtym czasie, charakterze, pozostając do dnia dzisiejszego jedynym opracowaniem monograficznym na ten temat. W późniejszym czasie zajął się problematyką uprawnień kierowniczych podmiotu zatrudniającego. Poświęcił temu wiele tekstów o różnym charakterze, a podsumowaniem jego przemyśleń w tym zakresie jest rozprawa habilitacyjna, a następnie książka wydana w 1977 r. pt. Uprawnienia kierownicze w umownym stosunku pracy, dzieło, które jest zgodnie zaliczane do największych dokonań polskiego prawa pracy. Inną płaszczyzną zainteresowań badawczych Profesora Henryka Lewandowskiego, zwłaszcza po okresie transformacji ustrojowej, było zbiorowe prawo pracy. Bardzo cenione są jego opracowania o partycypacji pracowniczej w zarządzaniu przedsiębiorstwem, o związkach zawodowych, układach zbiorowych 106 pracy i sporach zbiorowych pracy. Profesor aktywnie uczestniczył również $w$ dyskusjach o potrzebie reformy prawa pracy, jakie toczyły się pod koniec lat osiemdziesiątych, a nieco później wiele razy wypowiadał się w kwestii celowości i zakresu nowelizacji kodeksu pracy w zmienionych uwarunkowaniach ustrojowych. Wiele uwagi poświęcił także skutkom, jakie w kontekście polskiego prawa pracy przyniosła akcesja naszego kraju do struktur europejskich. Pisał o tym zarówno w polskich czasopismach naukowych, jak i w opracowaniach obcojęzycznych. Ze szczególnym zainteresowaniem spotkało się opracowanie współredagowane przez Profesora pt. Wpływ prawa wspólnotowego (Unii Europejskiej) na prawo wewnętrzne. Przykład Francji i Polski (Warszawa 2003), które ukazało się również we francuskiej wersji językowej. W swojej wielowątkowej twórczości Profesor Henryk Lewandowski podejmował też wiele innych tematów. Pisał m.in. o granicach liberalizacji prawa pracy, o przeciwdziałaniu stosowaniu umów cywilnoprawnych do zatrudnienia pracowniczego, o roli prawa pracy $\mathrm{w}$ walce $\mathrm{z}$ bezrobociem, o implikacjach restrukturalizacji przedsiębiorstw dla prawa pracy, o zatrudnieniu $\mathrm{w}$ administracji publicznej.

W swojej pracy naukowej bardzo często sięgał do komparatystyki. Dawał temu wyraz wielokrotnie. W większości jego opracowań pojawiają się wątki porównawcze. Publikował często (kilkadziesiąt tekstów) w wydawnictwach zagranicznych i w językach obcych (w szczególności po francusku). Sam bywał w różnych zagranicznych ośrodkach naukowych 
na stażach lub jako profesor wizytujący, ale także zapraszał do Łodzi gości z wielu krajów. Uczestniczył w licznych konferencjach międzynarodowych, w tym zwłaszcza w europejskich i światowych kongresach prawa pracy, gdzie prezentował raporty krajowe (Seul 1994) bądź komunikaty naukowe. Był organizatorem wielu konferencji międzynarodowych. Do największych dokonań w tym zakresie należy zaliczyć konferencje: Droit du travail dans l'entreprise (1984), Les accords d'entreprise (1990), Le syndicalisme contemporain et son avenir (1995), Influence de droit communautaire sur le droi interne. Cas de la France et de la Pologne (2003). Organizował też z powodzeniem konferencje krajowe, które cieszyły się zawsze wielkim zainteresowaniem, miał bowiem Profesor szczególny dar stwarzania podczas tych spotkań atmosfery, która sprzyjała nie tylko konstruktywnej wymianie poglądów, ale i nawiązywaniu przyjacielskich relacji między uczestnikami. Wielokrotnie był redaktorem naukowym publikacji zbiorowych.

Poważne są również osiągnięcia dydaktyczne Profesora Henryka Lewandowskiego. Prowadził z dużym powodzeniem wiele wykładów (poza kursowym wykładem z prawa pracy, także wykłady z europejskiego prawa pracy i prawa urzędniczego). Na jego seminariach przygotowano ponad 200 prac magisterskich. Był promotorem w dziewięciu przewodach doktorskich. Warto podkreślić, że seminarium doktorskie przez niego prowadzone miało otwarty charakter i przyciągało, poza pracownikami naukowymi, także wielu przedstawicieli praktyki. Z myślą o praktyce powołał do życia podyplomowe studia z prawa pracy, cieszące się wielkim zainteresowaniem, które do dziś przyciąga liczne rzesze słuchaczy. 



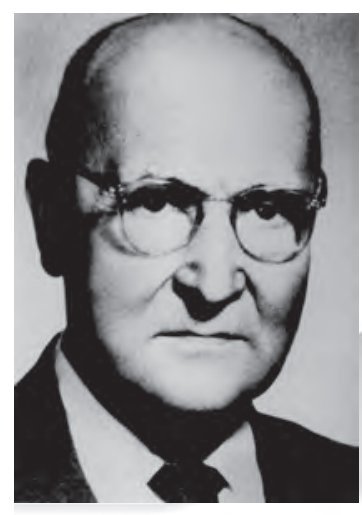

Marcin Kostwiński

\section{Marian Lisiewski (1886-1965)}

9 C arian Lisiewski urodził się 3 lutego 1886 r. w Poznaniu. Tam też ukońpraktykę bankową. W roku 1907 rozpoczął studia prawnicze na uniwersytecie w Lipsku, które kontynuował do 1910 r. w Berlinie i Kilonii, składając następnie pierwszy egzamin prawniczy. Po ukończeniu studiów wyższych odbył praktykę sądową w Nadrenii, gdzie pracował jako referendariusz sądowy. W 1915 r. zdał egzamin asesorski i został mianowany asesorem sądowym w Kolonii. Tego samego roku powołano go do wojska i służył do zakończenia pierwszej wojny światowej w armii niemieckiej.

Pod koniec 1918 r. wstąpił do nowo powstałego wojska polskiego, gdzie służył w randze kapitana. W roku 1919 pracował w Wojskowym Sądzie Okręgowym w Szamotułach oraz w Ministerstwie byłej Dzielnicy Pruskiej jako delegat przy Sądzie Okręgowym w Poznaniu. Marian Lisiewski powrócił do wymiaru sprawiedliwości w 1920 r. w charakterze sędziego okręgowego. Od 1926 r. piastował urząd wiceprezesa Sądu Okręgowego w Poznaniu. W roku 1928 został powołany na sędziego Sądu Najwyższego, które to stanowisko zajmował aż do chwili przejścia w stan spoczynku. Równocześnie w latach 1935-1939 pozostawał członkiem Trybunału Kompetencyjnego.

Wkrótce po wybuchu drugiej wojny światowej Marian Lisiewski wraz z Sądem Najwyższym został ewakuowany do Dubna, a następnie do Rumunii. Stamtąd z początkiem 1940 r. przedostał się do Rzymu, pozostając we Włoszech do końca 1944 r. Na początku roku 1945 przeniósł się do Londynu. W czasie wojny utrzymywał się pracując jako nauczyciel języków i tłumacz, prowadził przy tym prace prawnicze. Pozostawał także współpracownikiem Ministerstwa Sprawiedliwości Rządu RP na uchodźstwie ${ }^{1}$. s. 139 .

1 Podaję za A. Bąkowskim, W poszukiwaniu idei państwa prawa, „Palestra” 2003, nr 7-8, 
Marian Lisiewski powrócił do kraju przy pierwszej nadarzającej się okazji, w listopadzie 1945 r., podejmując niezwłocznie swoje obowiązki w Sądzie Najwyższym. W latach 1946-1950 pozostawał równolegle delegowany do Departamentu Ustawodawczego w Ministerstwie Sprawiedliwości. Od 1947 do 1949 r. był członkiem komisji ds. kodyfikacji prawa cywilnego. $\mathrm{W}$ tym czasie podjął również pracę $\mathrm{w}$ charakterze nauczyciela akademickiego. W latach 1945-1950, jako zastępca profesora, pełnił funkcję kierownika Katedry Postępowania Cywilnego na Uniwersytecie Warszawskim. Równocześnie wykładał ogólną teorię prawa, prawo cywilne i administracyjne na Politechnice Warszawskiej, a w latach 1949-1950 - postępowanie cywilne na Wyższej Szkole Prawniczej im. T. Duracza.

Z początkiem roku akademickiego 1950/1951 objął po Jerzym Jodłowskim $^{2}$ stanowisko Kierownika Katedry Postępowania Cywilnego na Uniwersytecie Łódzkim, które zajmował aż do przejścia na emeryturę w 1960 r. W 1953 r. został powołany na członka Komisji Kodyfikacyjnej, stając się referentem głównym projektu Kodeksu postępowania cywilnego opublikowanego w 1960 r. Tytuł naukowy docenta nadano Marianowi Lisiewskiemu w 1955 r., pomimo braku stopnia doktora. We wniosku o przyznanie tytułu docenta i w załączonych do niego opiniach autorstwa profesora Jerzego Jodłowskiego, profesora Józefa Litwina i profesora Adama Szpunara podkreślano jednak niezmiernie ważną pozycję Mariana Lisiewskiego w Sądzie Najwyższym, jego niebywałą erudycję i przedwojenny dorobek naukowy, a także nieprzeceniony wkład w unifikację prawa cywilnego i kodyfikację prawa cywilnego procesowego.

Za najważniejsze opracowanie naukowe Mariana Lisiewskiego uznawana jest monografia pt. Uznanie w Polsce wyroków zagranicznych, która ukazała się w 1938 r. - w częściach - na łamach „Polskiego Procesu Cywilnego". Stanowiła ona pierwsze w polskim piśmiennictwie tak szerokie opracowanie tego zagadnienia, pozostając przez lata jedną $\mathrm{z}$ najistotniejszych pozycji naukowych z zakresu międzynarodowego postępowania cywilnego, cenioną za wnikliwą analizę tematu oraz precyzję i przejrzystość rozumowania. Poza tym dorobek naukowy Mariana Lisiewskiego dotyczył w znacznej mierze problematyki związanej z jego aktywnością w komisjach kodyfikacyjnych, w szczególności tematyki części ogólnej prawa cywilnego, prawa spadkowego oraz struktury postępowania cywilnego. Był również autorem licznych glos do orzeczeń Sądu Najwyższego oraz odpowiedzi na pytania prawne publikowanych w „Czasopiśmie

${ }^{2}$ Który został kierownikiem Katedry Postępowania Cywilnego na Uniwersytecie Warszawskim. Zob. M. Jędrzejewska, Jerzy Jodłowski (1909-2000), „Studia Iuridica” 2001, nr 39, s. 199. 
Adwokatów Polskich”, „Palestrze”, „Ruchu Prawniczym, Ekonomicznym i Socjologicznym”, „Państwie i Prawie” oraz w „Nowym Prawie”.

Został odznaczony Krzyżem Kawalerskim i Krzyżem Komandorskim Orderu Odrodzenia Polski ${ }^{3}$ oraz Czechosłowackim Orderem Białego Lwa III Klasy. Władał biegle językami niemieckim tudzież francuskim, porozumiewał się również po włosku i angielsku. Był jednym z najwybitniejszych prawników doby przedwojennej i okresu powojennego, a zarazem wielkim autorytetem naukowym. Pozostawił po sobie trwały ślad uwieczniony w tekście Kodeksu postępowania cywilnego. W pamięci współpracowników zapisał się jako uosobienie wyjątkowej prawości charakteru i wielkiego umiłowania zawodu prawnika ${ }^{4}$. Po jego śmierci Witold Broniewicz pisał:

do zagadnień, które przychodziło mu rozwiązywać w ramach działalności sądowej, kodyfikacyjnej i naukowej podchodził nie w sposób beznamiętny, z mędrca tylko szkiełkiem i okiem, ale z prawdziwym, zawsze żywym zapałem. Myśl Jego bogata wiedzą i doświadczeniem pozwalała Mu tworzyć konstrukcje zadziwiające swoją trafnością 5 .

Marian Lisiewski zmarł w dniu 25 grudnia 1965 r. w Milanówku, gdzie na stałe mieszkał. Miał żonę Ludwikę oraz dwie córki: Danutę i Hannę.

${ }^{3}$ Podaję za: W. Broniewicz, Marian Lisiewski (1886-1965), [w:] Kronika, Łódź 1966, s. 145.

${ }^{4}$ Ibidem, s. 145-146.

5 Ibidem, s. 146. 



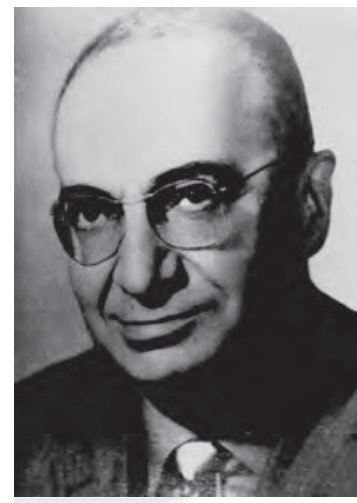

\section{Maria Karcz-Kaczmarek, Katarzyna Wlaźlak}

\section{Józef Litwin (1904-1966)}

Yózef Litwin, syn Rafała i Justyny z Sonenbergów, urodził się 16 listopaC da 1904 r. w Łodzi w inteligenckiej rodzinie lekarskiej. Wykształcenie średnie uzyskał w roku 1923, kończąc Wyższą Szkołę Realną Zgromadzenia Kupców m. Łodzi. W tym samym roku podjął studia na Wydziale Prawa Uniwersytetu Warszawskiego, a w 1927 r. uzyskał tytuł magistra praw. W latach 1931-1939 był zatrudniony na stanowisku asystenta, a później starszego asystenta w Katedrze Prawa Administracyjnego w Łódzkim Oddziale Wolnej Wszechnicy Polskiej.

W latach 1928-1929 odbył czynną służbę wojskową uzyskując stopień podporucznika rezerwy. Wybuch drugiej wojny światowej zastał Józefa Litwina w szeregach Wojska Polskiego. Brał czynny udział w obronie Warszawy, skąd dostał się do niewoli niemieckiej. W czasie wojny zesłany do Niemiec, więziony był w obozach jenieckich: Oflagach XI B, XII A i II C w Woldenbergu (obecnie Dobiegniewo).

Po zakończeniu drugiej wojny światowej Józef Litwin kontynuował rozwój naukowy. W roku 1947 uzyskał stopień doktora praw na Wydziale Prawa Uniwersytetu im. Adama Mickiewicza w Poznaniu. Jego promotorem był prof. dr Marian Zimmermann. W listopadzie roku 1948 został powołany na stanowisko zastępcy profesora i kierownika Katedry Prawa Administracyjnego na Wydziale Prawa nowo powstałego Uniwersytetu Łódzkiego. Doktor Józef Litwin został mianowany profesorem nadzwyczajnym prawa administracyjnego we wrześniu roku 1950, a w lutym 1959 r. uzyskał tytuł profesora zwyczajnego prawa administracyjnego. Z wielkim zaangażowaniem sprawował także ważne funkcje uniwersyteckie. W latach 1949-1955 był prodziekanem i dziekanem Wydziału Prawa Uniwersytetu Łódzkiego, w latach 1955-1960 prorektorem UŁ. Profesor Józef Litwin działał na rzecz rozwoju Uniwersytetu Łódzkiego, doceniając i podkreślając istotne znaczenie tejże Uczelni dla regionu, co znalazło wyraz m.in. w opracowaniu Znaczenie Wydziału Prawa Uniwersytetu Eódzkiego 
dla Łodzi i Okręgu Łódzkiego, [w:] Dwadzieścia lat Wydziału Prawa Uniwersytetu Łódzkiego dla naszego miasta i jego okręgu².

Józef Litwin był aktywnym i twórczym członkiem wielu organizacji naukowych, m.in. Komitetu Nauk Prawnych PAN, Łódzkiego Towarzystwa Naukowego, należał do Zarządu Głównego Zrzeszenia Prawników Polskich. W latach 1960-1963 był członkiem Rady Głównej Szkolnictwa Wyższego, pełnił funkcję przewodniczącego Zespołu Rzeczoznawców Prawa w ramach Sekcji Studiów Uniwersyteckich tej Rady. Był także członkiem Wyższej Komisji Dyscyplinarnej dla Pracowników Nauki Szkół Wyższych przy Ministrze Szkolnictwa Wyższego oraz członkiem najwyższej instancji dyscyplinarnej adwokatury.

Działalność naukową Profesora Józefa Litwina uzupełniała i wzbogacała jego zawodowa aktywność prawnicza. W latach 1928-1934 odbył w Łodzi aplikację sądową oraz aplikację adwokacką pod patronatem znanego, tragicznie zmarłego podczas wojny, łódzkiego adwokata Emila Montlaka². Zawód adwokata wykonywał po złożeniu egzaminu adwokackiego w roku 1934 do roku 1950, kiedy to został mianowany profesorem Uniwersytetu Łódzkiego. W roku 1945 pracował w urzędującym wówczas w Łodzi Departamencie Ustawodawstwa Ministerstwa Sprawiedliwości. Pełnił ponadto funkcję radcy prawnego w kilku urzędach, instytu114 cjach państwowych i samorządowych. W latach 1947-1950 był członkiem Naczelnej Rady Adwokackiej.

Na uwagę zasługuje ponadto aktywna działalność polityczna i społeczna Profesora, podejmowana z głębokiego przeświadczenia o konieczności praktycznej realizacji idei sprawiedliwości społecznej i wrażliwości na ludzkie problemy. Bezpośrednio po zakończeniu drugiej wojny światowej został członkiem PPS, do której należał do 1948 r., a następnie członkiem PZPR. Działalność polityczno-społeczna skupiona była przede wszystkim na problemach dotyczących rodzinnego miasta - Łodzi, której był nieodrodnym synem i „,żywą kroniką"3. Przez dziesięć lat, to jest w latach 1947-1957, Józef Litwin sprawował mandat radnego Wojewódzkiej Rady Narodowej w Łodzi, łącząc tę funkcję z obowiązkami przewodniczącego Komisji Porządku Publicznego tejże Rady.

Spuścizna naukowa i publicystyczna Profesora Litwina jest wielka i zróżnicowana. Obejmuje kilkanaście książek i około 100 artykułów. Oprócz prac z prawa administracyjnego i historii regionu łódzkiego, pisał prace $\mathrm{z}$ historii sądownictwa i czasopiśmiennictwa prawniczego, dotyczą-

1 Łódź 1967, s. 26-33.

2 Z. Albrecht, Wspomnienie pośmiertne. Profesor dr Józef Litwin, „Palestra” 2009, nr 7-8, s. 205 .

3 I. Grajewska, Józef Litwin, „Państwo i Prawo” [dalej: PiP] 1966, z. 12, s. 920. 
ce zagadnień prawnych w literaturze pięknej, historii kultury, dydaktyki szkoły wyższej, a nawet numizmatyki. Wiele prac, m.in.: Prawo o aktach stanu cywilnego z komentarzem ${ }^{4}$; Prawo szkót wyższych. Teksty $i$ komentarze $e^{5}$ do dziś uznaje się za fundamentalne dla polskiego piśmiennictwa $\mathrm{w}$ dziedzinie prawa administracyjnego.

Dotąd w polskiej doktrynie prawa administracyjnego za najpełniejszy uznawany jest - zaproponowany przez J. Litwina - katalog zasad rejestracji stanu cywilnego. Mimo że uczynił to ponad pół wieku temu, dalej w znacznym stopniu zasady te zachowują swą aktualność ${ }^{6}$. Nikt - naszym zdaniem - dotychczas nie zdefiniował trafniej „oczywistego błędu pisarskiego" jak Profesor Józef Litwin w swoim komentarzu do dekretu z dnia 8 czerwca 1955 r. Prawo o aktach stanu cywilnego ${ }^{7}$. Za „oczywisty błąd pisarski" Profesor uważał taką niedokładność, która nie wkradłaby się do aktu, gdyby uczestnicy czynności wykazali należytą oględność. W szczególności chodzi o przeoczenie wskutek tego, że coś źle odczytano, źle dosłyszano, "połknięto” przy pisaniu, wpisano w niewłaściwej rubryce albo przeinaczono części wyrazu. Dodać trzeba, że w 2013 r. w Lublinie została utworzona Fundacja Instytut Naukowy im. Prof. Józefa Litwina, która jest wydawcą czasopisma prawniczego „Metryka. Studia z Zakresu Prawa Osobowego i Rejestracji Stanu Cywilnego".

W naukowym dorobku Profesora na szczególną uwagę zasługuje również praca Postępowanie administracyjne. Postępowanie karno-administracyjne. Postępowanie przymusowe w administracji. Objaśnione orzecznictwem sadów najwyższych i okólnikami ministerialnymi ${ }^{8}$. Drugie wydanie tej pozycji ukazało się w 1948 r. Trwałe miejsce w literaturze prawniczej zdobyły ponadto prace poświęcone legislacji administracyjnej (Uchwały rad narodowych. Wzory i przykłady'; Niedomagania techniki legislacyjnej w prawie administracyjnym $i$ gospodarczym $\left.{ }^{10}\right)$, stosunkom między prawem administracyjnym i cywilnym ( $Z$ problematyki styku prawa cywilnego z prawem administracyjnym ${ }^{11}$ ), wykładni prawa administracyjnego (Drogi ujednolicenia wykładni prawa administracyjnego ${ }^{12}$ ) czy zagadnieniom sądownictwa

${ }^{4}$ Łódź 1949; wyd. II, Warszawa 1961.

${ }^{5}$ Współautor, Warszawa 1955.

6 Z. Duniewska, M. Lewicki, Akty stanu cywilnego, [w:] Prawo administracyjne materialne. Pojęcia, instytucje, zasady, red. Z. Duniewska, B. Jaworska-Dębska, M. Stahl, Warszawa 2014, s. 154.

7 Warszawa 1961.

8 Warszawa 1935.

9 Warszawa 1955.

10 „Przegląd Ustawodawstwa Gospodarczego” 1957, nr 4, s. 121-127 i nr 5, s. 170-176.

${ }^{11} \mathrm{PiP}, 1965$, z 4, s. 540-555.

12 PiP, 1965, z. 10, s. 472-483 
administracyjnego (Problematyka sadownictwa administracyjnego. Zagadnienia organizacji i procedury $\left.{ }^{13}\right)$.

Profesor Józef Litwin współpracował z większością wydawanych w Polsce czasopism prawniczych, w tym jako członek komitetów redakcyjnych („Państwo i Prawo”, „Palestra”). Wielokrotnie reprezentował polską naukę na międzynarodowych konferencjach, w tym jako generalny referent. Odgrywał na tych zagranicznych spotkaniach znaczącą rolę dzięki ogromnej erudycji i biegłej znajomości czterech języków obcych. W bogatym dorobku naukowym Profesora znajdujemy kilka francusko- i węgierskojęzycznych pozycji wydanych w Paryżu, w Brukseli oraz w Budapeszcie (w tym La lutte contre la pollution des eaux par l'industrie, Institut International des Sciences Administratives, Bruxelles 1965). Profesor Litwin podjął się opracowania rosyjsko-polskiego słownika prawniczego ${ }^{14}$ a także tłumaczeń na język polski obcojęzycznych książek prawniczych.

W ramach zadań dydaktycznych Profesor prowadził wykłady oraz seminaria, których uczestnicy opracowali poważną liczbę prac magisterskich. Był promotorem w szeregu przewodów doktorskich i habilitacyjnych, przede wszystkim na pozałódzkich wydziałach prawa. Za szczególne osiągnięcia w dziedzinie dydaktyczno-wychowawczej, organizacji procesu dydaktycznego oraz prac związanych z kształceniem młodej ka116 dry naukowej otrzymał w 1963 r. Nagrodę Indywidualną II stopnia Ministra Szkolnictwa Wyższego.

Był laureatem Nagrody Miasta Łodzi w dziedzinie nauk humanistycznych (1965). W uznaniu wybitnych zasług położonych zarówno na polu działalności naukowej, dydaktycznej, jak i organizacyjnej w aparacie państwowym został odznaczony Krzyżem Kawalerskim i Oficerskim Orderu Odrodzenia Polski, Złotym Krzyżem Zasługi, Medalem X-lecia Polski Ludowej i Honorową Odznaką Miasta Łodzi.

Profesor Litwin posiadał encyklopedyczną wiedzę i miał fenomenalną pamięć. Władał znakomicie słowem, był wybitnym znawcą polskiej i obcej literatury ${ }^{15}$. Należał - jak wspominał Profesor Eugeniusz Smoktunowicz - do najbardziej popularnych postaci wśród profesorów Uniwersytetu Łódzkiego ${ }^{16}$. Wyróżniał się niepospolitym talentem pedagogicznym i silnym odziaływaniem wychowawczym na młodzież. Miał dar jasnego przedstawiania najtrudniejszych nawet zagadnień, ukazywał je od różnych stron, posługując się przy tym po mistrzowsku dowcipem. Wśród

13 "Nowe Prawo” 1955, nr 10, s. 3-19.

14 Warszawa 1960, współredakcja J. Nowacki,

15 Z. Albrecht, op. cit., s. 206.

16 E. Smoktunowicz, Józef Litwin (1904-1966), [w:] Dwadzieścia lat Wydziału Prawa Uniwersytetu Łódzkiego, Łódź 1967, s. 23-25. 
studentów i absolwentów cieszył się ogromnym i zasłużonym autorytetem. Liczni z nich, znalazłszy się w trudnej sytuacji życiowej, zwracali się do Profesora o radę i pomoc, których nigdy im nie odmawiał ${ }^{17}$.

Nieustannie pomagał także młodszym kolegom. Niezwykle życzliwy i serdeczny stosunek Profesora Litwina do pracowników Katedry sprawiał, że traktował ich wprost po ojcowsku ${ }^{18}$. Był uważany za prekursora w dwóch doniosłych sprawach: w pojmowaniu stosunków międzyludzkich $\mathrm{w}$ środowisku naukowym oraz $\mathrm{w}$ tym, co z pewnym uproszczeniem można nazwać postawą otwartą w nauce prawa. Wierzył głęboko w wartość prawa i jego sens we współżyciu ludzi i wierze tej dawał świadectwo w swoich pracach. Dzieło jego życia było służbą dla ludzkich wartości w prawie ${ }^{19}$.

Profesor Józef Litwin zmarł przedwcześnie, po kilkumiesięcznej chorobie, 11 października 1966 r. w Łodzi, z którą był związany szczególnie mocno, wszechstronnie, wręcz nierozerwalnie przez cały okres swojej wybitnej działalności naukowej oraz aktywności społeczno-politycznej. Jako naukowiec, społecznik, a przede wszystkim jako dobry człowiek całym swoim życiem potwierdził słuszność łacińskiej paremii Breve tempus aetatis satis longum est ad bene honesteque vivendum ${ }^{20}$ (krótki okres życia jest dostatecznie długi na to, aby żyć dobrze i uczciwie). Pięknie napisał też o Józefie Litwinie Profesor Franciszek Longchamps: „jeśli jest wśród nas pewien klimat, który pragniemy rozwijać i utrwalić, klimat wzajemnego zaufania i przyjaźni w nauce, to w jego stworzeniu ogromny był udział zmarłego naszego Przyjaciela, Jego serca i Jego umysłu"21. Profesora Józefa Litwina pożegnano 15 października 1966 r. na Cmentarzu Komunalnym w Łodzi.

17 E. Smoktunowicz, Kronika. Józef Litwin (1904-1966), „Zeszyty Naukowe Uniwersytetu Łódzkiego" 1967, Nauki Humanistyczno-Społeczne, ser. I, z. 52, s. 158.

18 Ibidem, s. 159.

19 F. Longchamps, Józef Litwin, P i P, 1966, z. 12, s. 919.

${ }^{20}$ I. Grajewska, op. cit., s. 919.

${ }^{21}$ F. Longchamps, op. cit., s. 918. 



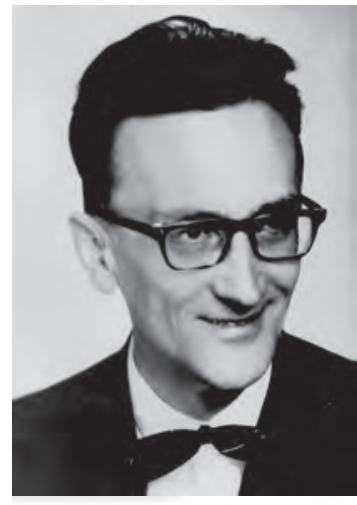

Zbigniew Góral

Jerzy Loga (1923-1988) ${ }^{1}$

erzy Loga urodził się w 1923 r. w Łodzi, z którą związał się na całe ży-
cie-z przerwą przypadająca na okres okupacji hitlerowskiej. W 1940 r. został bowiem wywieziony do Niemiec na roboty przymusowe. Do Polski wrócił w kwietniu 1945 r. Po uzyskaniu świadectwa dojrzałości pracował w latach 1945-1947 w Zrzeszeniu Handlu. W 1946 r. podją studia na Wydziale Prawa Uniwersytetu Łódzkiego, kończąc je w 1950 r. W tym samym roku został zaangażowany do pracy w charakterze pracownika pomocniczego w Katedrze Prawa Pracy, gdzie przeszedł wszystkie szczeble kariery naukowej. W 1953 r. został starszym asystentem w tej Katedrze. W roku 1961 uzyskał stopień doktora na podstawie rozprawy pt. Urlopy wypoczynkowe dla pracowników zatrudnionych w przemyśle i handlu, która została wyróżniona konkursie „Państwa i Prawa”. Od lutego 1961 r. Rada Wydziału powołała go na stanowisko adiunkta. W 1966 r. odbył półroczny staż naukowy w Szwajcarii. W 1976 r. uzyskał stopień naukowy doktora habilitowanego nauk prawnych, przedstawiając rozprawę pt. Wypadek przy pracy. Pojęcie prawne 2 . Od 1977 r. był zatrudniony na stanowisku docenta. Na emeryturę przeszedł w roku 1983. Nie zaprzestał jednak, pomimo ciężkiej choroby, aktywności naukowej i dydaktycznej (w ograniczonym wymiarze etatowym na Wydziale Prawa i Administracji UŁ pracował jeszcze przez dwa lata). W trakcie zatrudnienia na UŁ dał się poznać jako bardzo dobry, choć wymagający, dydaktyk. Prowadził wykłady, seminaria i ćwiczenia. Wypromował sporą liczbę magistrów. Był też kierownikiem cieszącego się dużym powodzeniem Studium Podyplomowego Prawa Pracy i Prawa Gospodarczego.

1 W przygotowaniu biogramu zostało wykorzystane m.in. opracowanie H. Lewandowskiego, Życie i działalność Jerzego Logi, [w:] Studia z prawa pracy. Księga pamiątkowa ku czci docenta Jerzego Logi, red. Z. Góral, Łódź 2007.

2 "Acta Universitatis Lodziensis" 1975. 
Dorobek naukowy Docenta Jerzego Logi obejmuje kilkadziesiąt pozycji, w tym książki, studia i artykuły, podręczniki i skrypty, recenzje oraz glosy do orzeczeń sądowych. Początkowo przedmiotem jego zainteresowań badawczych była problematyka urlopów pracowniczych, a zwłaszcza urlopów wypoczynkowych. W okresie poprzedzającym uzyskanie doktoratu oraz w późniejszym czasie napisał na ten temat kilka znaczących artykułów. Warto wymienić tu następujące opracowania: Utrata prawa do urlopu w świetle przepisów ustawy urlopowej i dekretu z 18 I 1956 roku3; Wymiar urlopu wypoczynkowego ${ }^{4}$, Ciagłość pracy a uprawnienia do urlopu; Urlop bezpłatny ${ }^{5}$; Nabycie prawa do urlopu wypoczynkowego $o^{6}$. Najistotniejszym dokonaniem z tego zakresu był oczywiście doktorat i bardzo wysoko oceniana, często przywoływana $\mathrm{w}$ literaturze przedmiotu, monografia pt. Urlopy wypoczynkowe (1963). Do problematyki urlopowej wracał również po uchwaleniu Kodeksu pracy (artykuł pt. Pracownicze urlopy wypoczynko$\left.w e^{7}\right)$. Drugim obszarem badań Docenta Jerzego Logi były wypadki przy pracy. Zainteresował się nimi w drugiej połowie lat siedemdziesiątych. Zaowocowało to kilkoma studiami i artykułami (Charakter zwiazku wypadku z praca w społecznym ubezpieczeniu wypadkowym ${ }^{8}$; Konwencja zwiazku przyczynowego w ubezpieczeniu społecznym od wypadów przy pracy ${ }^{9}$; Ewolucja zakresu ochrony ubezpieczeniowej przed skutkami wypadków przy pracy ${ }^{10}$ ), 120 a przede wszystkim wydaną w 1975, a następnie w 1981 r. książka, na podstawie której habilitował się. Interesował się także wieloma innymi zagadnieniami z zakresu prawa pracy. Był niekwestionowanym znawca niemieckojęzycznej literatury przedmiotu. Znajdujemy tego potwierdzenie w kilku artykułach: O projekcie austriackiego kodeksu pracy ${ }^{11}$; Szwajcarska ustawa o pracy w przemyśle, rzemiośle i handlu ${ }^{12}$; Krok ku kodyfikacji prawa pracy w Niemieckiej Republice Federalnej ${ }^{13}$. Zabierał głos na temat najbardziej kontrowersyjnych regulacji w Kodeksie pracy (por. np. artykuł pt. Refleksje nad nieuzasadnionym wypowiedzeniem umowy o prace przez zakład pracy $\left.{ }^{14}\right)$, pisał także o potrzebie nowelizacji kodeksu pracy (Uwagi na tle projektu zmiany

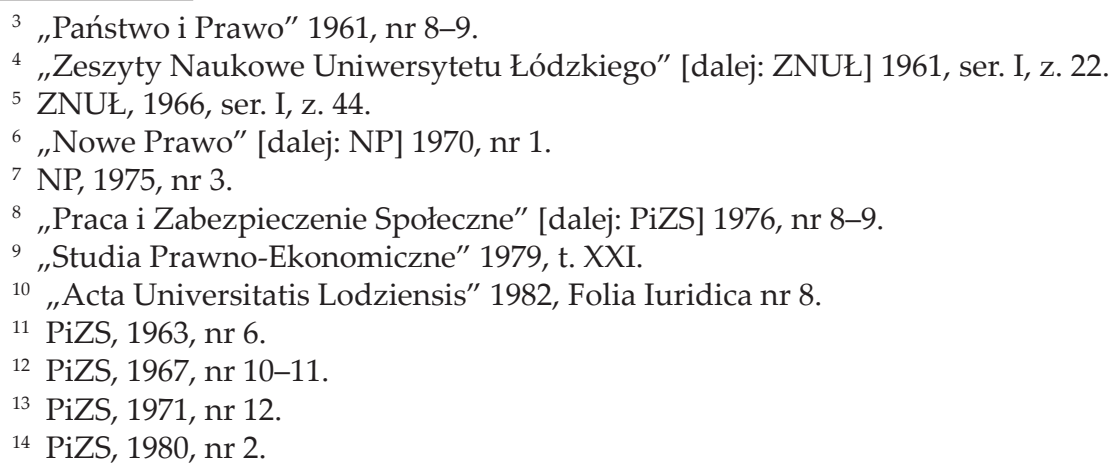


kodeksu pracy $\left.{ }^{15}\right)$. Jego uwage przyciągała także historia prawa pracy. Poruszał tę problematykę m.in. $\mathrm{w}$ opracowaniu pt. Stosunki pracy w okresie międzywojennym w łódzkim przemyśle włókienniczym, [w:] Włókniarze łódzcy, Łódź 1966, a przede wszystkim w tekście zatytułowanym Polskie prawo pracy w okresie międzywojennym, opublikowanym w $1981 \mathrm{r}$. w drugim obiegu, nakładem Wolnej Wszechnicy Polskiej. Był autorem licznych i bardzo cenionych w środowisku, często krytycznych, glos do orzeczeń Sądu Najwyższego.

Charakteryzując sylwetkę Docenta Jerzego Logi trudno nie odnieść się do innych przejawów jego działalności, nie tylko o naukowym charakterze. To dzięki staraniom Docenta biblioteka Katedry Prawa Pracy należy do najlepszych tego typu placówek w Polsce, a bez wątpienia zgromadzony w niej zbiór niemieckojęzycznych pozycji jest najbogatszy. Był bezkompromisowym obrońcą wartości religijnych. Miał niezwykłą wrażliwość społeczna, która sprawiała, że zawsze stawał po stronie ludzi pracy. Wspierał swoją wiedzą i doświadczeniem związki zawodowe. W okresie przedsierpniowym jego pomoc otrzymywał często ZNP, a po Sierpniu 1980 r. bez reszty oddał się ideałom „Solidarności”. Był członkiem tej organizacji i jej cenionym ekspertem. Pomimo pogarszającego się szybko stanu zdrowia włączył się czynnie w działalność ",Solidarności”, nie zważając na niebezpieczeństwa, jakie się z tym wiązały, zwłaszcza po ogłoszeniu stanu wojennego. Nie tylko dzielił się wtedy swoją wiedzą w ramach nielegalnych spotkań, pisząc $\mathrm{w}$ drugim obiegu, ale także biorąc aktywny udział w demonstracjach organizowanych w obronie „Solidarności”, co było powodem represji stosowanych wobec niego przez władze komunistyczne. 



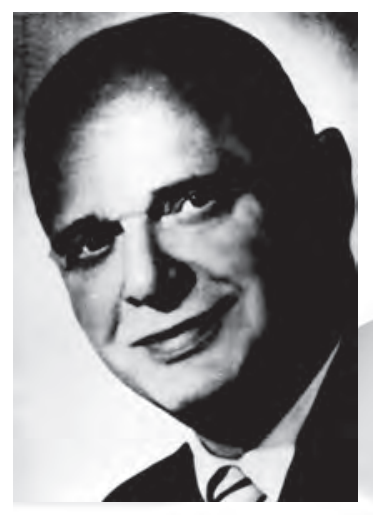

Jacek Matuszewski

\section{Jerzy Telesfor Lubowicki (1898-1964)}

Riografia profesora skarbowości, dwojga imion Jerzego Telesfora LuSbowickiego, organizatora i pierwszego kierownika Katedry Prawa Finansowego na Wydziale Prawa Uniwersytetu Łódzkiego, z jednej strony zawierać w sobie musi elementy typowe dla pokolenia, które przyszło na świat pod zaborami, rozwijało się w czasach II Rzeczypospolitej, a lata dojrzałe spędzało w powojennej Polsce Ludowej. Z drugiej jednak mamy do czynienia z postacia, która w lata najbardziej dla nas istotne - lata pracy na Uniwersytecie Łódzkim, wchodziła z endecką przeszłościa, z życiorysem ,skalanym” wieloletnią pracą w strukturach publicznych sanacyjnej Polski, a do tego dojeżdżającą z Warszawy ${ }^{1}$. A i charakter osobowości Profesora, opisywanej przez najbliższych mu współpracowników, nie ułatwia opracowania. Zapamiętany z ostatnich wykładów, przez jednego ze studentów, jako „starszy, lecz postawny pan, o donośnym i spokojnym głosie, nienagannie ubrany, chociaż staroświecko" ${ }^{2}$, w opinii podwładnych miał być ,"człowiekiem apodyktycznym, bezceremonialnym i bezkompromisowym w swoich relacjach ze środowiskiem finansistów i prawników-finansowców"3.

Przyszedł na świat w Warszawie 5 stycznia 1898 r., w niezamożnej rodzinie carskiego urzędnika, przeniesionego wkrótce na podwarszawską prowincję, do Mińska Mazowieckiego. Z tego powodu uczęszczający do warszawskiego gimnazjum Jerzy Telesfor musiał codziennie, aż do ewakuacji rosyjskiej administracji w 1915 r., dojeżdżać do szkoły. Stancja była za droga. Naukę w szkole średniej kontynuował w Petersburgu (Szkoła

${ }^{1}$ Choć w przeciwieństwie do większości takich pracowników uniwersytetu utrzymywał, obok mieszkania warszawskiego, także mieszkanie w Łodzi.

${ }^{2}$ C. Kosikowski, Profesor Jerzy Lubowicki i stado jego „baranów”, [w:] Prawo skarbowe i prawo finansowe. Szkoły i uczniowie, Księga Dedykowana Pamięci Profesora Jerzego Lubowickiego, red. C. Kosikowski, Białystok 2013, s. 48.

${ }^{3}$ Ibidem, s. 57. 
Handlowa) kończąc ją ze świadectwem dojrzałości w 1917 r., już w czasach wielkiej społecznej i politycznej przemiany. Nie ulega wątpliwości, że - tak jak w przypadku znacznej części rówieśników - jego wybitną, ale i oryginalna, osobowość kształtowały wielkie wydarzenia polityczne dwudziestego wieku. Wpływały też na niego znakomite postacie, wśród których się obracał. Tej oryginalności wybitnego znawcy problematyki skarbowości państwa nie poszukują przygotowywane dotychczas układne, niesłychanie formalnie poprawne opisy żywota, w których Profesor Lubowicki jawi się li tylko jako człowiek-naukowiec ${ }^{4}$. Aż tyle i tylko tyle ${ }^{5}$.

Jak setki innych młodych Polaków z terenów cesarstwa chciał wracać do Polski. Już wolnej. Droga do kraju wiodła go przez jednostki powstającej polskiej armii. Najpierw trafił do I Pułku Ułanów (zwanych później krechowieckimi), by następnie w I Korpusie Polskim pełnić rozmaite funkcje $\mathrm{w}$ wojskowej rachubie, gdyż stan zdrowia uniemożliwiał mu służbę liniową. Po rozbrojeniu i rozformowaniu Korpusu przez Niemców wrócił do Warszawy, gdzie pracując podjął studia w szkole wyżej, właśnie powołanej na potrzeby kształcenia kadr odrodzonego państwa - w Szkole Nauk Politycznych. Lubowicki skończył na Wydziale Politycznym trzyletnie studia (1918-1920), by następnie podjać kolejne na Uniwersytecie Warszawskim. Nie wiadomo dlaczego je rzucił i rozpoczął naukę na Wydziale Prawno-Ekonomicznym Uniwersytetu Poznańskiego, pracując przy tym w Warszawie ${ }^{6}$. Studia ekonomiczno-polityczne, według programu trzyletniego, odbył w latach 1921-19247, by następnie, również w Poznaniu, pod opieką Edwarda Taylora przygotować (1927) rozprawę doktorską Polityka podatkowa Polski. Ukończenie studiów wiązało się z zatrudnieniem

${ }^{4}$ Por. np. biogram napisany przez L. Kurowskiego w Polskim słowniku biograficznym [dalej: PSB], Wrocław 1973, t. XVIII, s. 71-72.

${ }_{5}$ Od niedawna dopiero obszerne przedstawienie postaci, znaczenia i dorobku naukowego można znaleźć w wydanej w 2013 r. w Białymstoku pod red. C. Kosikowskiego Księdze Dedykowanej Pamięci Profesora Jerzego Lubowickiego zatytułowanej: Prawo skarbowe i prawo finansowe. Szkoły i uczniowie...

${ }^{6}$ Można przypuszczać, że przyczyna wynikała z nastawienia politycznego, objawiającego się w endeckiej aktywności politycznej i publicystyce, por. Przyczynek do traktatu o ochronie mniejszości narodowych, Poznań 1921, ss. 16. Zob. też J. Małecki, Poznańska szkota podatkowa okresu dwudziestolecia międzywojennego, [w:] Prawo skarbowe i prawo finansowe. Szkoły i uczniowie..., s. 40, który sugeruje, że: „,to dla swojego przyszłego Mistrza [Edwarda Taylora] i studiów poznańskich porzucił on czasowo rodzinną Warszawę".

75 lipca 1924 r. uzyskał „prawo do używania tytułu magistra nauk ekonomiczno-politycznych". Warto zauważyć, że poznańskie studia Lubowickiego miały nieco eksternistyczny charakter, przebywał tam bowiem tylko przez pół roku (1922) utrzymując się z korepetycji, rok zaś akademicki 1922/1923 spędził w Warszawie, pracując w Delegacji Polskiej ds. Repatriacji i dopiero od końca 1923 r. powrócił do Poznania, gdzie pozostał do ukończenia studiów. 
w Ministerstwie Skarbu, a doktorat otworzył przed nim szansę awansów zawodowych (1928-1934 - kierownik wydziału w Izbie Przemysłowo-Handlowej, następnie [1934] naczelnik wydziału, a od roku 1936 dyrektor departamentu podatków i opłat w Ministerstwie Skarbu) ${ }^{8}$, jak również drogę kariery dydaktyczno-naukowej: został asystentem, a od $1936 \mathrm{r}$. wykładowcą w Wyższej Szkole Handlowej w Warszawie. Współpracował w tym czasie z najwybitniejszymi specjalistami finansów publicznych. Wśród nich, obok Edwarda Taylora, z którym bliskie stosunki utrzymywał aż do śmierci, wymienić trzeba uważanego za twórcę systemu skarbowego odrodzonej Polski Bolesława Markowskiego, Jerzego Michalskiego (legislator finansów publicznych, minister skarbu 1921-1923) czy Czesława Klarnera (minister przemysłu i handlu, a następnie minister skarbu).

Lata drugiej wojny światowej przetrwał w Warszawie, zatrudniony w strukturach samorządowych (Stołeczny Komitet Samopomocy Społecznej, Magistrat m. Warszawy), wykazując równocześnie aktywność w podziemnym nauczaniu akademickim (wykładał skarbowość w konspiracyjnej Akademii Nauk Politycznych) z jednej strony, a z drugiej angażując się w funkcjonowanie departamentu finansowego Delegatury Rządu Londyńskiego na Kraj.

W swej twórczości naukowej w czasach II Rzeczypospolitej Profesor publikował wyłącznie studia dotyczące podatków ${ }^{9}$. Prace te zawierały, oprócz analizy procesu kształtowania się polskiego systemu podatkowego i administracji podatkowej, także rozważania o ich skutkach i uwagi dotyczące potrzebnych w tym zakresie reform. Swe badania nad tradycyjnym systemem podatkowym zamknął przygotowaną w okresie okupacji rozprawą habilitacyjną Podatki jako środek polityki ekonomicznej.

Zdawał też sobie sprawę, że w powojennej Polsce istota, system i funkcje podatków ulegną radykalnej przemianie, wraz z reformą skarbowości związaną z przekształceniami ustrojowymi. Nie uległ pokusie usłużnego dostarczania argumentów pojawiającym się koncepcjom odrzucenia tradycyjnych konstrukcji publicznego prawa finansowego. Nie akceptował też tak wówczas politycznie ponętnych i popularnych, ale systemowo niepewnych, prawnie niedopracowanych pomysłów tworzenia nowoczesnego, socjalistycznego prawa finansowego, nie uznającego pojęć tradycyjnej skarbowości: pieniądza, podatku itd. Tak właśnie przeciwstawił się, i to skutecznie, forsowanym przez grupę lewicowych ekonomistów koncepcjom rezygnacji z budżetu państwa i zastąpienia go, według radzieckich

${ }^{8}$ Szczegółowo funkcje publiczne tego okresu wylicza L. Kurowski, PSB, 1973, t. XVIII, s. 71.

${ }^{9}$ J. Małecki, Poznańska szkoła podatkowa okresu dwudziestolecia międzywojennego..., s. $40-42$. 
wzorów, bilansem finansowym państwa ${ }^{10}$. Obok odegrania poważnej roli $\mathrm{w}$ rozwoju teoretycznych badań, podkreślić trzeba także kapitalne znaczenie dla praktyki finansów publicznych powojennej Polski jego prac z zakresu budżetu państwa oraz bankowości. Odniósł sukces przeciwstawiając się podatkowi od wynagrodzeń. Interesował się też ważnym, skomplikowanym, a długo niedocenianym w powojennej rzeczywistości, zagadnieniem finansów lokalnych ${ }^{11}$.

Był człowiekiem rzetelnych badań. Rozumiał znaczenie ogromnego, w powojennych czasach, wpływu na polską skarbowość marksizmu i powstających na tej podstawie dzieł autorów radzieckich. Studiował je gruntownie, a dzięki znakomitej, wyniesionej jeszcze z lat dziecięcych, znajomości języka rosyjskiego, mógł sobie pozwolić na dokonywanie przekładów na język polski powstających na terenie Związku Radzieckiego prac. Poza tym z ogromnym zaangażowaniem i dużą bezpośredniością wypowiadał się w opracowaniach recenzyjnych.

W powojennej rzeczywistości zmieniły się też zawodowe preferencje Jerzego Lubowickiego. Na pierwszym miejscu usytuował pracę naukową. Po wyzwoleniu znalazł się w Łodzi, gdzie obok funkcji urzędniczych ${ }^{12}$ od początku, podejmując wkrótce równoczesne zatrudnienie na etacie profesora na Uniwersytecie Warszawskim ${ }^{13}$, zajmował się pracą organizatorską na Uniwersytecie Łódzkim ${ }^{14}$. Tu udało mu się wykształcić badaczy, którzy już po jego śmierci wywarli znaczący wpływ na polski system prawa finansowego (Marian Weralski, Natalia Gaj1515). Był też na Wydziale Prawa

${ }^{10}$ Silnie podkreśla to ostatnio T. Dębowska-Romanowska, Cechy istotne budżetu w ramach ustawy budżetowej w świetle Konstytucji RP, [w:] Prawo skarbowe i prawo finansowe. Szkoty i uczniowie..., s. 91-92.

${ }^{11}$ Już w okresie międzywojennym zaangażowany był w tej dziedzinie jako delegat ministra skarbu w Międzyministerialnej Komisji Współpracy z Samorządem Gospodarczym.

${ }_{12}$ Piastował w Łodzi funkcje kierownicze w Tymczasowym Zarządzie Państwowym i w „Społem”. Przez kolejne lata pracował jako zastępca dyrektora Departamentu Inwestycji w Centralnym Urzędzie Planowania, w grudniu 1948 r. uzyskał ministerialną zgodę „na pełnienie zajęcia ubocznego $\mathrm{w}$ charakterze pracownika państwowego $\mathrm{w}$ dziale finansowym Biura Komitetu Ekonomicznego Rady Ministrów", był też rzeczoznawcą naukowym CKK dla Pracowników naukowych (od 1953 r.). Piastował również liczne inne funkcje, takie jak przewodniczący Rady Naukowej w Ministerstwie Finansów; był członkiem Międzynarodowego Instytutu Finansów Publicznych, b. WTN, czy ŁTN.

13 Od 1947 r. zajmował tam stanowisko profesora nadzwyczajnego, a od 1960 r. profesora zwyczajnego.

${ }^{14}$ Od 1948 r. sprawował także opiekę nad pozbawionymi naukowego przewodnika młodymi pracownikami Katedry Finansów Wyższej Szkoły Ekonomicznej w Łodzi.

15 „Wystąpił w roli promotora wielu prac doktorskich" - czytamy w biogramie Jerzego Lubowickiego, sporządzonym przez Grażynę Bałtruszajtys i Marię Superę, Z dziejów katedr skarbowości i prawa skarbowego oraz katedr prawa finansowego w Polsce, red. A. Kostecki, Kraków 2010, s. 101. 
założycielem zmieniającej nazwę Katedry Prawa Finansowego. Wobec ministerialnych oporów nie powiodło się natomiast, mimo zaangażowania władz Wydziału i Uczelni, zapewnienie na łódzkiej uczelni stabilizacji. Aż do 1954 r. funkcjonował bowiem Profesor na Uniwersytecie na podstawie umowy zlecenia, a następnie już na podstawie kontraktu, ale zawieranego na czas określony i odnawianego - znowu nie bezterminowo - ze znacznym poślizgiem ${ }^{16}$.

W swojej pracy akademickiej doceniał rolę dydaktyki i odpowiedzialność nauczyciela akademickiego za poziom kształcenia. W pierwszych, siermiężnych latach po wyzwoleniu podejmował się przekładów podręczników uczonych radzieckich, jak i przygotowania własnych, a także tak potrzebnych w dydaktyce prawa wydawnictw tekstów źródłowych. Prace te kontynuowano w łódzkiej Katedrze po jego śmierci. Nie uchylał się od udziału w przygotowaniu opracowań syntetycznych na najwyższym poziomie bądź w pracach przeglądowych, zawierających omówienie i ocenę postulowanych i realizowanych zmian prawa finansowego ${ }^{17}$.

Rozpoczęty pierwszą młodzieńczą publikacją w $1921 \mathrm{r}$. dorobek naukowy, który - licząc od wydanego w 1927 r. doktoratu - rozkłada się - z pominięciem czasu okupacji, na okres ponad 30 lat, zawiera w sobie „ledwo" 54 pozycje $^{18}$. W epoce systemu punktowego twórczość w tego rodzaju wymiarze zapewne utrudniałaby wszelkie awanse, spychając naukowca z tak "miernym” dorobkiem na margines życia akademickiego. Profesor Jerzy Telesfor Lubowicki miał jednak to szczęście, że czasów „kudrycyzacji” nauki nie dożył, jego zaś niewątpliwa kompetencja, daleko posunięta bezkompromisowość i szczere zaangażowanie w racjonalną budowę polskiej skarbowości publicznej, mogły być dla dobra Rzeczypospolitej niejednokrotnie skutecznie wykorzystywane.

Zmarł nagle w Sopocie, 5 czerwca 1964 r. - pochowany na Cmentarzu Powązkowskim w Warszawie.

${ }^{16}$ Jesteśmy skłonni do przypuszczenia, że u podstaw tych trudności nie legły kwestie ideologiczne - prof. Lubowicki na Uniwersytecie Warszawskim funkcjonował bez takich problemów, pełniąc nawet funkcję prodziekana. Przyczyna najprawdopodobniej tkwiła w wyznawanej w tym okresie polityczno-biurokratycznej koncepcji jednoetatowości pracowników nauki.

${ }^{17}$ C. Kosikowski, Profesor Jerzy Lubowicki i stado jego „baranów”..., s. 58-59.

${ }_{18}$ Zob. Bibliografia prac Profesora Jerzego Lubowickiego, [w:] Prawo skarbowe i prawo finansowe. Szkoty i uczniowie..., s. 21-24. 



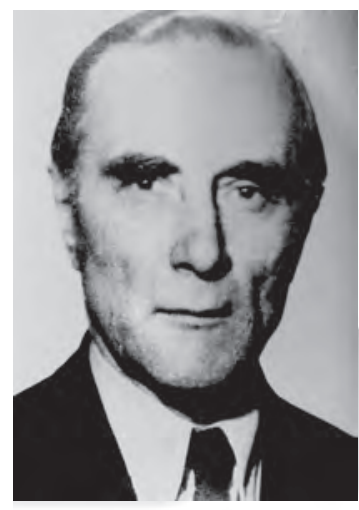

Tomasz A. J. Banyś, Łukasz Jan Korporowicz

\section{Borys Łapicki (1889-1974)}

W $2014 \mathrm{r}$. minęły dwie ważne rocznice związane z osobą szego dziekana Wydziału Prawa Uniwersytetu Łódzkiego. Sto dwudziesta piąta rocznica urodzin oraz czterdziesta rocznica śmierci ${ }^{1}$.

Urodził się 7 stycznia 1889 r. w Krasnojarsku na Syberii w polskiej rodzinie zesłańców styczniowych (Hektor Łapicki - dziadek profesora - był naczelnikiem cywilnym województwa mińskiego w roku $1863^{2}$ ). Mimo polskiego pochodzenia B. Łapicki przejął wiele cech charakterystycznych dla rosyjskiej liberalnej inteligencji schyłku wieku XIX. Nie jest to zresztą zaskakujące, skoro uczęszczał do dobrego gimnazjum moskiewskiego, a następnie podjął studia prawnicze na Uniwersytecie Moskiewskim, ukończone w roku 1911. Jak zwraca uwagę J. Kodrębski ${ }^{3}$ już w tym okresie głównym przedmiotem zainteresowań B. Łapickiego stały się prawo cywilne oraz prawo rzymskie. Z uwagi na panującą w kraju i na uniwersytecie sytuację polityczną, po ukończeniu studiów musiał jednak skupić uwagę na zagadnieniach współczesnego prawa cywilnego, a jego pierwsza

${ }^{1}$ Na temat profesora Borysa Łapickiego skreślono jak dotąd wiele wspomnień i not: J. Kodrębski, Borys Łapicki (1889-1974), „Czasopismo Prawno-Historyczne” [dalej: CPH] 1974, nr 26, s. 287-288; idem, Borys Łapicki (1889-1974), "Acta Universitatis Lodziensis. Zeszyty Naukowe Uniwersytetu Łódzkiego. Nauki Humanistyczno-Społeczne" 1976, ser. I, z. 6, s. 269-284; idem, Borys Łapicki (1889-1974), [w:] A. Pikulska-Robaszkiewicz (red.), Profesorowi Janowi Kodrębskiemu in memoriam, Łódź 2000, s. 93-115; M. Zabłocka, Borys Łapicki (1889-1974), [w:] G. Bałtruszajtys (red.), Profesorowie Wydziatu Prawa i Administracji Uniwersytetu Warszawskiego 1808-2008, Warszawa 2008, s. 162-163. Warto odnotować ponadto, że sylwetką naukową prof. B. Łapickiego zajmuje się aktualnie mgr Mateusz Bromboszcz, doktorant na Wydziale Prawa i Administracji Uniwersytetu Śląskiego.

2 E. Kozłowski, Łapicki Hektor, [w:] Polski Stownik Biograficzny, Wrocław 1973, t. XVIII, nr 1, s. 210-211.

3 J. Kodrębski, Borys Łapicki (1889-1974), „Acta...", s. 270. 
opublikowana praca naukowa dotyczyła spadkobrania małżonków ${ }^{4}$. W roku 1912 udał się na stypendium naukowe do Paryża i Londynu ${ }^{5}$. W czasie wojny światowej powrócił do Rosji, gdzie w roku 1916 uzyskał stopień naukowy magistra prawa (odpowiadający dzisiejszej habilitacji) ${ }^{6}$. Pierwszą samodzielną pracę naukowo-dydaktyczną podjął w roku 1917 jako profesor prawa rzymskiego i cywilnego w mającym status uczelni wyższej Demidowskim Liceum Prawniczym w Jarosławiu ${ }^{7}$. Co prawda wśród jej profesorów było wielu wybitnych prawników, jednak okres rewolucji i lat późniejszych nie sprzyjał prowadzeniu badań naukowych $\mathrm{w}$ tej uczelni, przekształconej później $\mathrm{w}$ uniwersytet ${ }^{8}$. Trudności występujące we wspomnianym okresie oraz tradycje patriotyczne spowodowały, że B. Łapicki zrezygnował z zajmowanej przez siebie katedry i wraz z całą rodzina, podróżując przez Rygę i Wilno', przybył w roku 1923 do Polski, gdzie od razu podjął pracę badawczą oraz dydaktyczną. Dzięki rekomendacji swojego mentora Leona Petrażyckiego ${ }^{10}$, B. Łapicki podjął pracę w Wolnej Wszechnicy Polskiej, gdzie objął katedrę prawa cywilnego i rzymskiego ${ }^{11}$. Wykładał też przedmioty prawnicze $\mathrm{w}$ założonym $\mathrm{w}$ roku 1928 łódzkim oddziale Wszechnicy ${ }^{12}$. W roku akademickim 1936/1937 Ministerstwo Wyznań Religijnych i Oświecenia Publicznego przeprowadziło weryfikację wykładowców akademickich WWP. W jej następstwie B. Łapicki otrzymał tytuł profesora zwyczajnego ${ }^{13}$. Jak wskazuje J. Kodrębski, z Wszechnicą profesor związał się bardzo ściśle, co też ta uczelnia doceniła, czyniąc go w roku 1938 jednym z prorektorów ${ }^{14}$.

${ }^{4}$ J. Kodrębski, Borys Łapicki (1889-1974), [w:] A. Pikulska-Robaszkiewicz (red.), Profesorowi..., s. 95.

5 Ibidem, s. 95.

${ }^{6}$ Ibidem.

7 J. Kodrębski, Borys Łapicki (1889-1974), „Acta...”, s. 271-272.

8 J. Kodrębski, Borys Łapicki (1889-1974), [w:] A. Pikulska-Robaszkiewicz (red.), Profesorowi..., s. 95. Na temat stosunku władz komunistycznych do nauki prawa rzymskiego zob. W. Wołodkiewicz, Europa i prawo rzymskie, Warszawa 2009, s. 94-95 oraz 109-110.

${ }_{9}$ Nie zabiliby panowie królika, cz. 1, Z Andrzejem Łapickim rozmawiaja Katarzyna Bielas i Jacek Szczerba, „Gazeta Wyborcza” 5 marca 1999 (http://niniwa22.cba.pl/lapicki_wywiad_1.htm).

${ }^{10} \mathrm{~W}$ ten sposób o relacji łączącej B. Łapickiego i L. Petrażyckiego wypowiada się m.in. Z. Rymaszewski w wywiadzie udzielonym redakcji "Czasopisma Prawno-Historycznego" 2007, t. LIX, z. 1, s. 235.

${ }^{11}$ J. Kodrębski, Borys Łapicki (1889-1974), [w:] A. Pikulska-Robaszkiewicz (red.), Profesorowi..., s. 96. Na temat Wolnej Wszechnicy Polskiej i jej szczególnej roli w II RP por. H. S. Dinter, Przedmowa, [w:] K. Baranowski, Oddziat Wolnej Wszechnicy Polskiej w Łodzi: 1928-1939, Warszawa-Łódź 1977, s. 3-5.

${ }^{12}$ K. Baranowski, op. cit., s. 64, 116.

${ }^{13}$ Ibidem, s. 35.

${ }^{14}$ J. Kodrębski, Borys Łapicki (1889-1974), [w:] A. Pikulska-Robaszkiewicz (red.), Profesorowi..., s. 96. 
W roku 1925 został ponadto mianowany zastępcą profesora w kierowanej przez Ignacego Koschembar-Łyskowskiego katedrze prawa rzymskiego na Uniwersytecie Warszawskim ${ }^{15}$. Stanowisko to zajmował przez dziesięć lat. Zdaniem J. Kodrębskiego, mimo pozornie drugoplanowej roli, to przede wszystkim B. Łapicki wykładał prawo rzymskie w tym okresie. Oprócz wykładu kursowego (w ramach którego omawiał część ogólną prawa rzymskiego, prawo osobowe, rodzinne, spadkowe i rzeczowe) prowadził on ćwiczenia z tego przedmiotu oraz odrębny wykład poświęcony rzymskiemu prawu rodzinnemu. Po objęciu warszawskiej katedry przez Władysława Kozubskiego w roku 1935, B. Łapicki już jako profesor WWP prowadził dalej na Wydziale Prawa UW ćwiczenia i wykłady zlecone ${ }^{16}$.

Wprawdzie główny nurt badań B. Łapickiego w tym okresie dotyczył problematyki prawa rzymskiego, to jednak Profesor był żywo zainteresowany toczącymi się ówcześnie pracami Komisji Kodyfikacyjnej Prawa Cywilnego. Wpływ na to miała z pewnością bliska znajomość z dwiema kluczowymi jej postaciami - L. Petrażyckim oraz I. Koschembar-Łyskowskim. Wyniki prac Komisji komentował w periodykach naukowych ${ }^{17}$.

Wraz z wybuchem drugiej wojny światowej B. Łapicki kontynuował działalność naukową i dydaktyczną. W tym okresie ukończył monografię dotyczącą historii ustroju starożytnego Rzymu, a także prace na temat kultury społecznej starożytnego Rzymu oraz oddziaływania tradycji rzymsko-bizantyńskiej na kulturę społeczną Europy. Rękopisy wszystkich wspomnianych wyżej prac uległy niestety zniszczeniu podczas Powstania Warszawskiego ${ }^{18}$. Jednocześnie, w ramach Wydziału Ekonomiczno-Prawnego WWP, prowadził tajne wykłady z zakresu prawa rzymskiego, teorii prawa, prawa państwowego oraz historii ustroju Polski. Treści przekazywane przez niego $\mathrm{w}$ trakcie wykładów były powielane $\mathrm{w}$ formie skryptów. Trzeba wreszcie wskazać, że w omawianym okresie B. Łapicki kierował pracą Wydziału ${ }^{19}$.

${ }^{15} \mathrm{Na}$ temat I. Koschembar-Łyskowskiego zob. W. Wołodkiewicz, Ignacy Koschembar-Łyskowski (1864-1945), [w:] G. Bałtruszajtys (red.), Profesorowie Wydziału Prawa i Administracji..., s. 90-93. Zob. także anegdoty zebrane na jego temat przez M. Jońcę w książce Prawo rzymskie. Marginalia, Lublin 2012, s. 189-190, 213-216 i 289.

16 J. Kodrębski, Borys Łapicki (1889-1974), [w:] A. Pikulska-Robaszkiewicz (red.), Profesorowi..., s. 96-97.

17 B. Łapicki, Przyczynek do nauki o prawach rzeczowych, "Gazeta Sądowa Warszawska” 1925, t. LIII, z. 19, s. 299-300 i „Gazeta Sądowa Warszawska” 1925, t. LIII, z. 20, s. 315-317 oraz idem, Zadośćuczynienie za szkodę niematerialna w projekcie polskiego prawa zobowiazań, „Palestra” 1925, t. II, z. 5, s. 761-770.

${ }_{18}$ M. Zabłocka, Borys Łapicki..., s. 163; J. Kodrębski, Borys Łapicki (1889-1974), „Acta...", s. 274.

${ }^{19}$ J. Kodrębski, Borys Łapicki (1889-1974), „Acta...", s. 273. 
Po zakończeniu działań wojennych w całym kraju podjęto wysiłki zmierzające do odbudowy kadry i zaplecza naukowego. W tym kontekście należy widzieć decyzję władz centralnych dotyczącą zlokalizowania w Łodzi - faktycznej stolicy państwa - nowego uniwersytetu. W maju 1945 r. rozpoczął działalność Uniwersytet Łódzki, który liczył wówczas sześć wydziałów, w tym Wydział Prawno-Ekonomiczny ${ }^{20}$. Pierwszym jego dziekanem został B. Łapicki, który pełnił tę funkcję w latach 1945/1946. Natomiast w latach 1946-1948 powierzono mu funkcję prodziekana. W tym samym czasie podjął on działania zmierzające do zorganizowania w ramach Wydziału zakładu prawa rzymskiego, którym następnie kierował aż do przejścia na emeryturę w roku $1960^{21}$.

Przedwojenny dorobek naukowy B. Łapickiego, na tle innych romanistów polskich tego okresu, prezentuje się dość skromnie. Jego zainteresowania badawcze koncentrowały się wokół dwóch kwestii: najstarszych dziejów prawa rzymskiego ${ }^{22}$ oraz władzy ojcowskiej ${ }^{23}$. Tuż przed wybuchem wojny B. Łapicki podjął pierwsze studia nad problematyką wartości etycznych prawa rzymskiego ${ }^{24}$. To ostatnie zagadnienie stało się przedmiotem długich badań kontynuowanych przez romanistę po drugiej wojnie światowej, których efektem było m.in. opublikowanie w roku 1948 podręcznika akademickiego ${ }^{25}$ oraz kilku prac monograficznych ${ }^{26}$. W tym okresie B. Łapicki zajął się również nowatorskim zagadnieniem poglądów

${ }^{20}$ Na temat pierwszych lat funkcjonowania Wydziału Prawa na UŁ zob. J. Kodrębski, Wydziat Prawa i Administracji Uniwersytetu Łódzkiego w latach 1945-1995, „Acta Universitatis Lodziensis" 1997, Folia Iuridica 64, s. 8-14.

${ }^{21}$ J. Kodrębski, Borys Łapicki (1889-1974), „Acta...”, s. 274-275.

22 B. Łapicki, Ustawy królewskie w starożytnym Rzymie. Zagadnienie ich autentyczności, „Pamiętnik Historyczno-Prawny” 1933, t. XII, z. 6, s. 303-332. Ponadto również w roku 1933 na WWP B. Łapicki wygłosił w ramach Collegium Publicum odczyt pt. Powstanie monarchii rzymskiej, zob. K. Baranowski, Oddziat Wolnej Wszechnicy Polskiej w Łodzi..., s. 123.

${ }^{23}$ B. Łapicki, Władza ojcowska w starożytnym Rzymie, cz. I: Czasy królewskie; cz. II: Czasy republikańskie, Warszawa 1933, ss. 230 oraz idem, Władza ojcowska w starożytnym Rzymie. Okres klasyczny, Warszawa 1937, ss. 124.

${ }_{24}$ B. Łapicki, Misericordia w prawie rzymskim, [w:] Księga pamiatkowa ku czci Leona Pinińskiego, t. II, Lwów 1936, s. 117-131 i idem, Jednostka i państwo w Rzymie starożytnym. Rozważania historyczne na tle przeobrażeń prawa i państwa w dobie obecnej, Warszawa 1939, ss. 294.

25 B. Łapicki, Prawo rzymskie, Warszawa-Łódź 1948. Warto zwrócić uwagę, że pierwszych sto kilkadziesiąt stron podręcznika autor poświęcił zagadnieniom etycznym. Na temat oceny podręcznika zob. J. Kodrębski, Borys Łapicki (1889-1974), „Acta...", s. 278 oraz M. Zabłocka, Romanistyka polska po II wojnie światowej, Warszawa 2002, s. 11.

${ }^{26}$ B. Łapicki, Etyczna kultura starożytnego Rzymu a wczesne chrześcijaństwo, Łódź 1958, ss. 332; idem, O spadkobiercach ideologii rzymskiej. Okres chrystianizacji cesarstwa rzymskiego, Łódź 1962, ss. 304; idem, Ideologia rzymska w średniowieczu Europy Zachodniej, Łódź 1964, ss. 180 . 
prawnych rzymskich niewolników oraz proletariuszy, które badał jednak w duchu ideologii marksistowskiej ${ }^{27}$.

Powszechnie uważa się, że Borys Łapicki nie pozostawił po sobie żadnego ucznia. Jednakże, zdaniem Zygfryda Rymaszewskiego, uczniem takim był J. Kodrębski, którego pierwsze prace noszą wyraźne znamiona wpływu jego Mistrza ${ }^{28}$.

Niewiele zachowało się do dziś informacji na temat sposobu bycia B. Łapickiego. Wiadomo jednak, że był osobą bardzo popularną wśród studentów. Popularność tę wiąże J. Kodrębski z jego talentem krasomówczym oraz dostojnym stylem bycia i majestatyczną sylwetką ${ }^{29}$. Wydaje się, że Profesor był świadomy tego, jakie wrażenie wywierał i starał się je podtrzymywać. Jednocześnie był osobą zasadniczą - starał się żyć zgodnie z etycznymi zasadami prawa rzymskiego, które wykładał ${ }^{30}$. We wspomnieniach jego syna - znanego aktora Andrzeja Łapickiego - odnaleźć można informację o tym, że Profesor - mimo swojej popularności - budził strach wśród studentów ${ }^{31}$. Słynął bowiem z dogłębnego sprawdzania ich wiedzy. Egzaminował w sposób surowy, lecz sprawiedliwy. Nierzadko jego pytania były podchwytliwe. Roman Tokarczyk, w swojej książce dotyczącej anegdot akademickich, przywołuje historię pewnego studenta, któremu B. Łapicki zadał pytanie o walkę klas w starożytnym Rzymie. Po wysłuchaniu długiej i rozbudowanej wypowiedzi studenta, opisującej walkę klas, profesor z wyraźną satysfakcją miał powiedzieć: "Znakomicie, znakomicie - tyle tylko, że w starożytnym Rzymie nie było walki klas" ${ }^{32}$.

Profesor Borys Łapicki zmarł 28 stycznia 1974 r. Odszedł w częściowym zapomnieniu środowiska naukowego ${ }^{33}$. Poza najbliższą rodziną

27 Przede wszystkim zob. B. Łapicki, Poglady prawne niewolników i proletariuszy rzymskich. Studium historyczne na tle bazy gospodarczej i antagonizmów klasowych, Łódź 1955, ss. 241.

${ }^{28}$ Z Profesorem Zygfrydem Rymaszewskim rozmawia Henryk Olszewski, „Czasopismo Prawno-Historyczne" 2007, 59.1, s. 239.

29 J. Kodrębski, Borys Łapicki (1889-1974), "Acta...", s. 280.

${ }^{30}$ Ibidem, s. 280-281 i Nie zabiliby panowie królika, cz. 1, Z Andrzejem Eapickim rozmawiaja Katarzyna Bielas i Jacek Szczerba... Profesor T. Szymczak w rozmowie z A. Pikulską-Radomską wspominał dramatyczną w jego ówczesnym odbiorze sytuację, w której zadzwonił mu w kieszeni budzik, odebrany właśnie od zegarmistrza. Stało się to podczas wykładu B. Łapickiego. Wszyscy słuchacze zmartwieli, a Profesor przerwał w pół słowa, odczekał z kamienną twarza, aż dźwięk ustanie, po czym kontynuował wykład.

${ }^{31}$ Nie zabiliby panowie królika, cz. 1, Z Andrzejem Łapickim rozmawiaja Katarzyna Bielas i Jacek Szczerba...

32 R. Tokarczyk, Antologia anegdoty akademickiej, Warszawa 2006, s. 286.

33 J. Kodrębski, Borys Łapicki (1889-1974), „Acta...", s. 269. 
i członkami Zakładu Prawa Rzymskiego w pogrzebie udział wziął tylko jeden przedstawiciel polskiej romanistyki - profesor Jerzy Falenciak z Uniwersytetu Wrocławskiego ${ }^{34}$. Mimo kontrowersji związanych z osobą Borysa Łapickiego pozostawił on przyszłym pokoleniom prawników jasny przekaz, że wartości etyczne prawa rzymskiego powodują iż jest ono niezbędnym elementem formacji intelektualnej przyszłego prawnika.

${ }^{34}$ Na podstawie relacji dr. Ireneusza Jakubowskiego. 


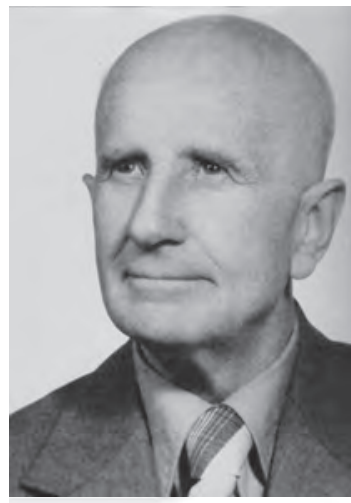

Lena Fijatkowska

Józef Matuszewski (1911-2003) ${ }^{1}$

Yózef Matuszewski urodził się 23 marca 1911 r. w Twardowie (gmina Cotlin) w Wielkopolsce, w rodzinie wiejskiego nauczyciela. Jego ojciec, Ignacy, prowadził wówczas szkołę powszechną w Kucharach, do której Józef uczęszczał w latach 1918-1921. Naukę kontynuował w staroklasycznym, ośmioklasowym gimnazjum w Gostyniu, gdzie jego rodzice przenieśli się właśnie po to, by umożliwić mu dalszą edukację; w roku 1929 złożył egzamin maturalny. Ponieważ marzył o zawodzie sędziego, rozpoczął studia prawnicze i ekonomiczne w Poznaniu, gdzie zamieszkał w akademiku, początkowo utrzymując się z korepetycji, a później dzięki uzyskanemu stypendium. Studiując dwa kierunki, znajdował jeszcze czas, by uczęszczać na zajęcia z historii, nauk pomocniczych historii, gramatyki opisowej i języka staro-cerkiewno-słowiańskiego. Już na II roku ukończył pracę magisterską pod tytułem Immunitet kościelny sądowy w Matopolsce $w$ XIII $w$., nagrodzoną brązowym medalem Uniwersytetu Poznańskiego, na trzecim zaś roku rozpoczął pod kierunkiem profesora Zygmunta Wojciechowskiego przygotowywanie rozprawy doktorskiej. Magistrem prawa został w roku 1933, ekonomii - w 1936 i w tymże też roku uzyskał stopień doktora prawa, przedstawiając rozprawę zatytułowaną Immunitet ekonomiczny $w$ dobrach Kościoła w Polsce do roku 1381. Pracę na uniwersytecie rozpoczął jeszcze w czasie studiów, jako wolontariusz (w latach 1931-1934 jako asystent przy seminarium historycznoprawnym), w roku 1934 został zastępcą starszego asystenta przy seminarium prawa publicznego, natomiast od roku 1935 był starszym asystentem przy seminarium historycznoprawnym. Po uzyskaniu doktoratu przez trzy lata studiował w słynnej i prestiżowej École des Chartes, École Pratique des Hautes Etudes i na Wydziale Prawa w Paryżu, gdzie przebywał dzięki stypendium

${ }^{1}$ Wykorzystane informacje pochodzą z książki Z. Rymaszewskiego i J. Matuszewskiego, Pasja nauki. Cena pasji, seria: Magistri Nostri. Profesorowie Wydziału Prawa Poznańskiego Uniwersytetu, Poznań 2014. 
Funduszu Kultury Narodowej. Pod kierunkiem wybitnego francuskiego mediewisty Louisa Halphena przygotował wówczas rozprawę habilitacyjną dotyczącą sądownictwa w średniowiecznej Szampanii, rękopis zaginął jednak w czasie wojny. Wybuch drugiej wojny światowej zastał go w Polsce, gdzie powrócił na wakacje. Okupację spędził w Radzyniu Podlaskim w Generalnej Guberni, w domu zamężnej siostry, pracując w niemieckiej hurtowni artykułów rolniczych. Pod koniec wojny Profesor znalazł się w Kielcach, gdzie rozpoczął prowadzenie zajęć na Wydziale Prawa i Humanistycznym Tajnego Uniwersytetu Ziem Zachodnich. Zaraz po zakończeniu wojny rozpoczął uwieńczone sukcesem starania o powrót na Uniwersytet Poznański. Już w kwietniu roku 1945 został powołany na stanowisko zastępcy profesora historii prawa na Zachodzie Europy, a rok później - adiunkta w Katedrze Historii Prawa na Zachodzie Europy (od roku 1950 Katedra Powszechnej Historii Państwa i Prawa). Rozpoczął przygotowywanie kolejnej rozprawy habilitacyjnej, tym razem dotyczącej prawa rugijskiego, którą obronił w roku 1947, natomiast w roku 1949 został docentem powszechnej historii ustrojów państwowych i prawa. Jednakże niechętny doń stosunek nowych władz skutkował kłopotami z uzyskaniem stałego zatrudnienia i poczuciem ciągłego braku stabilizacji, pogłębionymi przeniesieniem w roku 1949 z Krakowa do Poznania 136 Mariana Jedlickiego, który przejął wykłady dotąd prowadzone przez Józefa Matuszewskiego. Również po śmierci Jedlickiego w roku 1954 nie on, lecz Michał Sczaniecki został kierownikiem Katedry Powszechnej Historii Państwa i Prawa. Mimo tych trudności wciąż niezwykle intensywnie pracował naukowo, uzyskując w roku 1959 tytuł profesora zwyczajnego. W tym samym roku został wybrany dziekanem Wydziału Prawno-Ekonomicznego. W roku 1963, po śmierci Jana Adamusa, zgodził się objąć stanowisko kierownika Katedry Powszechnej Historii Państwa i Prawa Uniwersytetu Łódzkiego, na którym pracował aż do przejścia na emeryturę w roku 1981, później pozostał w tej Katedrze profesorem (zatrudnionym na ćwierć etatu) aż do śmierci 14 października 2003 r. Otrzymał liczne nagrody rektora za osiągnięcia naukowe, państwowe odznaczenia i ordery (m.in. krzyże Kawalerski, Oficerski i Komandorski Orderu Odrodzenia Polski, Medal KEN), nagrodę im. Oswalda Balzera, a w roku 2001 został doktorem honoris causa Uniwersytetu Łódzkiego.

Dorobek naukowy Profesora, zawierający publikacje w trzech językach (polskim, niemieckim i francuskim) jest ogromny (obejmuje ponad 250 publikacji, w tym 20 książek) i niezwykle wszechstronny, tak że nie sposób wymienić choćby wszystkich dziedzin, które stały się przedmiotem jego zainteresowań. Do najważniejszych należy oczywiście historia prawa, w szczególności słowiańskiego, któremu poświęcił między innymi pracę habilitacyjną Studia nad prawem rugijskim (Poznań 1947) i rozprawę 
Artykuły słowiańskie Zwierciadła Saskiego², polskiego (m.in. Aqua abrenuntiationis. Studium ze średniowiecznego prawa prywatnego ; Proles illegitima w polskim prawie ziemskim ${ }^{4}$, jak również prawa niemieckiego w Polsce średniowiecznej (m.in. Prawo sądowe na wsi polskiej lokowanej na prawie niemieckim ${ }^{5}$ ). Wiele uwagi poświęcił Profesor zagadnieniom historii ustroju (przykładem może być rozprawa Sprzedawalność urzędów w Polsce ${ }^{6}$ ) i historii polskiej skarbowości (rozprawa doktorska Immunitet ekonomiczny w dobrach Kościoła w Polsce do r. 1381, Poznań 1936 i późniejsze artykuły). Wydawał także źródła; tu wśród jego prac na pierwszym miejscu wymienić należy edycję Księgi Elblaskiej (w roku 1959). Zajmował się również historią społeczną (Polskie nazwisko szlacheckie ; Geneza polskiego chama ${ }^{8}$ ), filologią (Geneza wspótczesnej terminologii prawnej'; Filologia w służbie historii ${ }^{10}$ ), metodologia, opublikował wiele szczegółowych i wnikliwych recenzji dzieł naukowych. Niewielka część dorobku Profesora została ponownie opublikowana w pięciu tomach Pism Wybranych, które ukazały się w Łodzi w latach 2000-2002.

2 "Czasopismo Prawno-Historyczne” [dalej: CPH], 1948, t. I, s. 25-74.

${ }^{3} \mathrm{CPH}, 1952$, t. IV, s. 164-237.

${ }^{4} \mathrm{CPH}, 1966$, t. XVIII, z. 2, s. 71-154.

5 "Studia z Dziejów Państwa i Prawa Polskiego" 1995, t. II, s. 40-75.

${ }^{6} \mathrm{CPH}, 1964$, t. XVI, z. 2, s. 101-174.

7 Łódź 1975.

8 Łódź 1982.

9 Sprawozdania Poznańskiego Towarzystwa Przyjaciół Nauk, Poznań 1963, s. 288-290.

10 „Acta Universitatis Lodziensis" 1978, ser. I: Nauki Humanistyczno-Społeczne, z. 32, s. 3-34. 



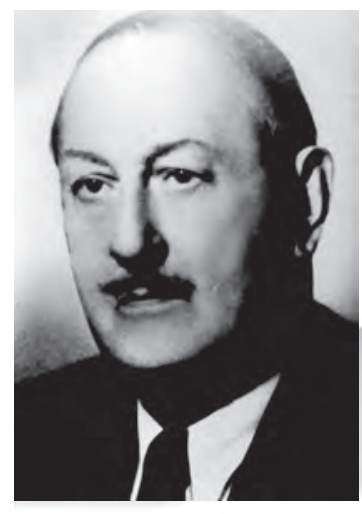

\section{Szymon Byczko}

\section{Jan Namitkiewicz (1880-1958)}

Sporządzenie biogramu Profesora Jana Namitkiewicza jest rzeczą trud$\int$ ną ponieważ ta wybitna postać nie doczekała się żadnego szerszego opracowania biograficznego. Miarą tego zapomnienia jest fakt, że jako jeden z niewielu znanych prawników nie ma swego miejsca w Wikipedii ${ }^{1}$.

Jan Namitkiewicz urodził się 23 maja 1880 r. w Lublinie. Wydział Prawa ukończył w 1904 r., na Uniwersytecie Warszawskim. Stopień doktora praw uzyskał w dwa lata później w Paryżu. W 1910 r. został adwokatem.

W latach 1908-1915 brał aktywny udział w działalności warszawskiego Towarzystwa Prawniczego. Towarzystwo to - utworzone w 1907 r. przez wybitnych starszych adwokatów, rejentów i radców Prokuratorii Generalnej (m.in. S. Bukowieckiego, K. Dunina, H. Konica, A. Suligowskiego) - prowadziło szeroko zakrojoną działalność odczytową i dyskusyjną. Jego celem było doskonalenie zawodowe i pogłębianie wiedzy prawniczej. W ramach Towarzystwa funkcjonowały sekcje odpowiadające podstawowym działom prawa publicznego i prywatnego. Do działalności tej dołączyli też młodsi wybitni prawnicy, jak W. Makowski, A. Mogilnicki, K. Lutostański, E. Rappaport i właśnie J. Namitkiewicz.

W 1915 r. był naczelnikiem kancelarii Straży Obywatelskiej Miasta Stołecznego Warszawy, której zadaniem było pilnowanie porządku w mieście po wycofaniu się z niego wojsk rosyjskich.

1 września 1917 r. został mianowany sędzią Sądu Okręgowego w Warszawie $^{2}$, a od 1919 r. był sędzią Sądu Apelacyjnego w Warszawie (mianowany przez Naczelnika Państwa Józefa Piłsudskiego na podstawie art. 7

${ }^{1}$ Szczególne podziękowanie za pomoc w opracowaniu tego biogramu należy się dr. hab. Adamowi Redzikowi z redakcji „Palestry”.

2 „Dziennik Urzędowy Departamentu Sprawiedliwości Tymczasowej Rady Stanu Królestwa Polskiego", nr 4 z dnia 19 września 1917 r. 
dekretu o najwyższej władzy Rzplitej Polskiej) $)^{3}$ W 1932 r. został sędzią Sądu Najwyższego.

Profesor Uniwersytetu Warszawskiego, Wolnej Wszechnicy Polskiej, Szkoły Nauk Politycznych w Warszawie.

Z ramienia Senatu UW sprawował funkcję kuratora akademickiej korporacji Coronia od chwili jej powstania (17 grudnia 1921) do 1928 r. Został też jej honorowym członkiem i filistrem.

Zainteresowania naukowe Jana Namitkiewicza w okresie międzywojennym obejmowały początkowo głównie prawo międzynarodowe. Od 1921 r. był sędzią w Trybunale Rozjemczym Mieszanym Niemiecko-Polskim z siedzibą w Paryżu, od 1929 r. sędzią w Trybunale Rozjemczym dla Górnego Śląska. Był też pełnomocnikiem Rządu na Kongresach Prawa Morskiego w Brukseli. Jego podpis widnieje m.in. pod tekstem Konwencji o ujednostajnieniu niektórych zasad, odnoszących się do przywilejów i hipotek morskich, podpisanej w Brukseli 10 kwietnia 1926 r. Jako delegat Rządu brał udział w Konferencji Prawa Wekslowego i Czekowego w latach 1930 i 1931 w Genewie. Pokłosiem naukowym jego działalności w tym zakresie była wydana w 1922 r. praca Mieszany trybunał Rozjemczy Polsko-Niemiecki, ustanowiony na zasadzie art. 304 Traktatu Wersalskiego.

Kolejne pola badawcze to prawo wekslowe i czekowe oraz prawo spółek. W 1924 r. Profesor Jan Namitkiewicz wydał Polskie prawo wekslowe, z uzasadnieniem Komisji kodyfikacyjnej oraz orzecznictwem niemieckim, a w 1927 r. Polskie prawo akcyjne. Jego komentarz do Kodeksu handlowego, wydawany w latach 1934-1937 był wielokrotnie wznawiany jeszcze w latach dziewięćdziesiątych wieku XX. Do opracowań o ogólniejszym charakterze należały praca z 1927 r. O najważniejszych zasadach badania prawa handlowego oraz wydany w 1934 r. Zarys prawa handlowego. Był współredaktorem „Kwartalnika Prawa Cywilnego”, , Przeglądu Prawa Handlowego” oraz założycielem „Miesięcznika Prawa Handlowego i Wekslowego”.

W czasie drugiej wojny światowej prowadził wykłady i inne zajęcia $\mathrm{z}$ prawa handlowego i prawa międzynarodowego $\mathrm{w}$ ramach tajnego nauczania organizowanego przez Konspiracyjny Wydział Prawa UW, który powstał w 1940 r. Konspiracyjne studium Prawa skupiało nie tylko studentów UW, lecz także studentów tzw. Uniwersytetu Ziem Zachodnich z siedzibą w Warszawie (powołany do życia przez profesorów Uniwersytetu im. Adama Mickiewicza przebywających w Warszawie, jako tajna uczelnia, w październiku 1940 r.). Od 10 marca do 2 listopada 1940 r. był więziony na Pawiaku.

Po wojnie Jan Namitkiewicz zamieszkał w Łodzi i został pierwszym dziekanem Wydziału Prawa Uniwersytetu Łódzkiego (1948/1949). Wy-

3 „Dziennik Urzędowy Ministerstwa Sprawiedliwości” nr 1, z 22 stycznia 1920, s. 9. 
kładał prawo handlowe i międzynarodowe prywatne. Powrócił także na stanowisko sędziego Sądu Najwyższego, w stan spoczynku przeszedł w 1953 r., po czym został ponownie wpisany na listę adwokatów.

W okresie powojennym Profesor Jan Namitkiewicz opublikował m.in. Komentarz do ustawy o majątkach porzuconych i poniemieckich (1945), dwutomowy Komentarz do Kodeksu zobowiazań (1949) $)^{4}$ oraz, w 1951 r., Prawo przedsiębiorstwa państwowego.

Zmarł 11 kwietnia 1958 r. w Łodzi, pochowany na Cmentarzu Rakowickim w Krakowie.

${ }^{4}$ wspólnie z A. Smolińskim. 



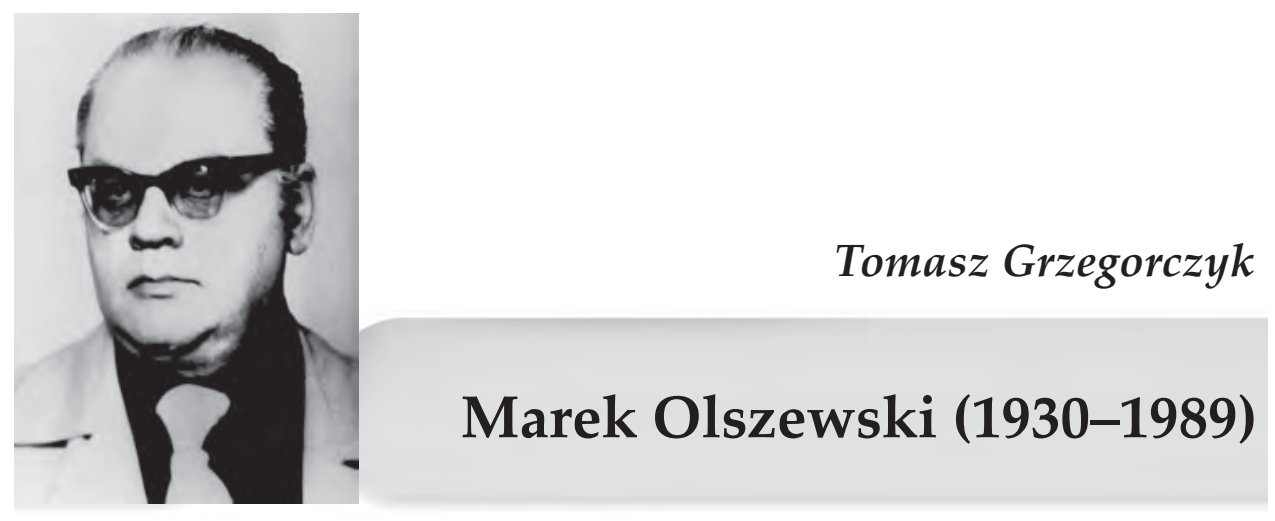
\( arek Olszewski urodził się w Łodzi w 1930 r. Okres okupacji spęwie ${ }^{1}$. W tym też czasie, w wyniku choroby, utracił władzę w nogach, której już nigdy nie odzyskał. W 1945 r. powrócił do swojego rodzinnego miasta. Studiował prawo na Uniwersytecie Łódzkim i Jagiellońskim i po tych studiach, w 1953 r., rozpoczął pracę na Wydziale Prawa UŁ, najpierw w Katedrze Prawa Karnego, a następnie w Katedrze Postępowania Karnego. Stąd też początkowo jego zainteresowania naukowe oscylowały wokół problematyki materialnego prawa karnego. Następnie włączył do ich kręgu także problematykę procesu karnego i prawa wykroczeń oraz postępowania w tych sprawach. Doktoryzował się w 1963 r. rozprawą pt. Postępowanie karne w sprawach o przestepstwa przeciwko bezpieczeństwu w lotnictwie cywilnym, a habilitował w 1974 r. na podstawie - opublikowanej w $1978 \mathrm{r}$. jako monografia - dysertacji pt. Ustrojowe i procesowe zasady orzecznictwa w sprawach o wykroczenia. Tytuł profesora nadzwyczajnego uzyskał w marcu 1989 r., na cztery miesiące przed nagłą śmiercią.

Jego dorobek naukowy obejmuje kilkadziesiąt publikacji, w tym monografie, podręczniki, skrypty, artykuły, szkice i recenzje. Co najmniej 1/3 z tych publikacji dotyczyła prawa wykroczeń. Był bowiem Profesor Marek Olszewski - obok Profesora Mieczysława Siewierskiego - współtwórcą tzw. łódzkiej szkoły prawa wykroczeń, obejmującej swymi badaniami nie tylko materialne, ale i procesowe prawo wykroczeń, akcentującej także wagę samego prawidłowego procedowania w tych sprawach, jako drogi do wydania właściwego, zgodnego z prawem materialnym i sprawiedliwego orzeczenia. Te zainteresowania są do dziś kontynuowane przez

${ }^{1} \mathrm{~W}$ opracowaniu uwzględniono wspomnienia pośmiertne po prof. M. Olszewskim: J. Tylmana - w „Państwo i Prawo” 1990, nr 3, s. 76-77 oraz T. Grzegorczyka, Z żałobnej karty, „Zagadnienia Wykroczeń" 1989, nr 4-5, s. 110-111, a także wspomnienia własne z kontaktów z Profesorem. 
jego uczniów i następców. Był on w tej dziedzinie - poza wskazaną wyżej habilitacją - także autorem studium Prawo o wykroczeniach, zamieszczonego w publikacji zbiorowej Stan i zadania nauk penalnych w Polsce (1983 r.), współautorem opracowania Prawo o wykroczeniach. Zarys (1987 r.), obejmującego po raz pierwszy w Polsce, i równie obszernie, obie sfery tego prawa, a także autorem licznych artykułów dotyczących materialnych i procesowych aspektów prawa o wykroczeniach, odnoszących się m.in. do jednoczynowego zbiegu przestępstwa i wykroczenia, stopnia szkodliwości społecznej jako podstawy rozgraniczenia tych czynów, wykroczeń trwałych, środków zaskarżania w sprawach o wykroczenia, uchylania prawomocnych rozstrzygnięć w tych sprawach czy kontroli sądowej nad orzecznictwem ówczesnych kolegiów. W sferze materialnego prawa karnego wypowiadał się z kolei m.in. w kwestiach warunkowego umorzenia postępowania, oszustw na szkodę konsumentów, ochrony bezpieczeństwa ruchu drogowego, na gruncie przepisów kodeksu karnego z 1969 r. czy fałszerstw dokumentów; ta ostatnia problematyka zaowocowała zresztą obszernym studium w opracowaniu System prawa karnego z 1989 r. Zajmował się też problematyką procesową różnorodnych przestępstw, $\mathrm{w}$ tym zagarnięcia mienia oraz kwestiami związanymi z postępowaniem odwoławczym i, szerzej, postępowaniem sądowym w sprawach karnych.

144 Był współautorem (z M. Siewierskim i J. Tylmanem) jedynego wówczas ogólnopolskiego podręcznika z zakresu procedury karnej (1971 i 1974 r.), obejmującego całe postępowanie karne, w którym opracował zagadnienia dotyczące właśnie postępowania odwoławczego, a także postępowań szczególnych i prowadzonych po uprawomocnieniu wyroku oraz w sprawach wojskowych i ze stosunków międzynarodowych.

We wszystkich swych naukowych wypowiedziach Marek Olszewski, dokonując gruntownej analizy problemu, którym się zajmował, formułował dobrze uzasadnione wnioski, dbając przy tym o precyzję i wręcz elegancję wypowiedzi. Wiele jego opracowań jest do dziś przywoływanych przez innych autorów zarówno odnośnie do kwestii rozumienia przepisów, które nie uległy zmianie (np. w sferze materialnego prawa wykroczeń), jak i zagadnień dogmatyczno prawnych, aktualnych mimo zaistniałych zmian lub istotnych dla rozumienia obecnych rozwiązań poprzez dokonanie prawidłowej historycznej ich wykładni (w sferze materialnego prawa karnego oraz procedury karnej i postępowania w sprawach o wykroczenia). Pozostawił po sobie więc bez wątpienia dorobek naukowy, który znalazł trwałe miejsce w nauce i doktrynie polskiego prawa, tak karnego materialnego, jak i procesowego sensu largo.

Był też Marek Olszewski wybitnym dydaktykiem i wychowawcą oraz wspaniałym kolegą. Mimo poważnych kłopotów z poruszaniem się, związanych ze wspomnianą chorobą z lat młodości, pozostawał optymistycz- 
nie nastawiony do życia, podchodził z dużą dozą humoru do codziennych jego trudności, dzięki czemu rozładowywał też różne, zdawałoby się kłopotliwe, sytuacje. Bardzo przy tym pracowity i obowiązkowy, jednocześnie przyjacielski dla współpracowników oraz życzliwie i przyjaźnie nastawiony do studentów. Jego wykłady i seminaria z postępowania karnego i prawa wykroczeń cieszyły się wśród tych ostatnich dużym uznaniem i żywym zainteresowaniem. Wypromował kilkuset dyplomantów oraz magistrów prawa i administracji. Opiekował się jednocześnie przez wiele lat studenckim ruchem naukowym na Wydziale Prawa i Administracji UŁ, przyczyniając się do jego rozwoju. Zawsze przy tym dostępny i otwarty na pomoc w rozwikływaniu problemów naukowych zarówno w przypadku młodszych kolegów w Katedrze, jak i studentów, w tym magistrantów. Aktywnie uczestniczył w kated ralnych seminariach dyskusyjnych nad dokonywanymi zmianami prawa i procesu karnego sensu largo oraz założeniami przygotowywanych w Katedrze rozpraw doktorskich i habilitacyjnych, wnosząc do tych dyskusji, dzięki swej ogromnej wiedzy i doświadczeniu życiowemu, wiele, trudnych do przecenienia, merytorycznych uwag i argumentów, pozwalających uzmysłowić sobie ich uczestnikom wieloaspektowość omawianych problemów i konsekwencje przyjęcia określonych rozwiązań czy określonego rozumienia nowych przepisów prawa.

Profesor Marek Olszewski był też promotorem i recenzentem w kilku przewodach doktorskich, a na Wydziale Prawa i Administracji UŁ prodziekanem do spraw studenckich. Jego działalność naukowa i dydaktyczna była kilkakrotnie nagradzana przez ówczesne Ministerstwo Szkolnictwa Wyższego, Nauki i Techniki. Za swoją działalność został też odznaczony m.in. Krzyżem Kawalerskim Orderu Odrodzenia Polski oraz Złotym Krzyżem Zasługi i Medalem Komisji Edukacji Narodowej.

Zmarł nagle, w pełni sił twórczych, 30 lipca $1989 \mathrm{r}$. 



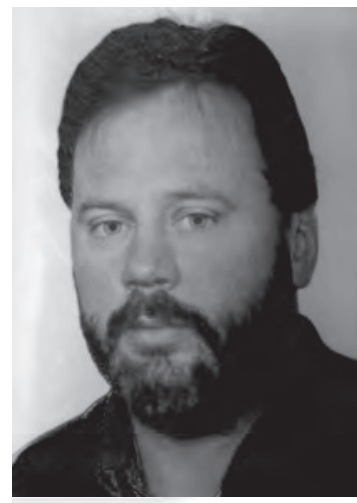

Agnieszka Liszewska

\section{Witold Olszowy (1952-1995)}

TSP latach 1970-1975 studiował na Wydziale Prawa Uniwersytetu Łódzkiego. Po uzyskaniu tytułu magistra prawa rozpoczął pracę na stanowisku asystenta w Katedrze Prawa Finansowego. We wrześniu 1981 r. obronił rozprawę doktorską pt. Pozycja obywatela w prawie finansowym PRL, napisaną pod kierunkiem prof. Cezarego Kosikowskiego, wysoko ocenioną przez recenzentów. W październiku 1981 r. przeszedł z Katedry Prawa Finansowego do nowo utworzonego Zakładu Prawa Zarządzania Gospodarką Narodową i podjął badania nad problematyką prawną zarządzania przedsiębiorstwami, nie tracąc jednak kontaktu z prawem finansowym. W tym czasie Witold Olszowy - obok działalności naukowej i dydaktycznej - angażował się w działalność na rzecz praktyki stosowania prawa gospodarczego prowadząc szkolenia, sporządzając opinie prawne, a także prowadząc obsługę prawną podmiotów gospodarczych. Był wziętym doradcą podatkowym, w czerwcu 1995 r. uzyskał wpis na listę adwokatów. Ukoronowaniem jego badań naukowych była rozprawa habilitacyjna pt. Podejmowanie decyzji podatkowej i jej sadowa kontrola w Polsce (Łódź 1994), na podstawie której w grudniu 1994 r. uzyskał stopień doktora habilitowanego.

Na dorobek naukowy Profesora Witolda Olszowego składa się około 30 publikacji, w tym dwie monografie, kilka studiów, artykuły, glosy i recenzje. Odrębną grupę stanowią niepublikowane opracowania badawcze oraz referaty wygłaszane na krajowych i międzynarodowych konferencjach naukowych. Twórczość naukowa Witolda Olszowego jest zróżnicowana i obejmuje zagadnienia podmiotowości finansowo-prawnej, odpowiedzialności podatkowej, "prawa powielaczowego" w dziedzinie finansów, planowania finansowego, polityki finansowej, finansowania inwestycji, roli ministra $\mathrm{w}$ zarządzaniu gospodarką narodowa, pozycji prawnej podmiotów zagranicznych w Polsce ${ }^{1}$. W całokształcie dorobku

\footnotetext{
${ }^{1}$ C. Kosikowski, Witold Olszowy (1952-1995), „Państwo i Prawo” 1996, nr 1, s. 87.
} 
dominują jednak opracowania poświęcone problematyce podatkowej, dotyczące opodatkowania osób fizycznych i podmiotów zagranicznych, legislacji i procedury podatkowej, w tym także opracowania wykonywane na zlecenie Rady Legislacyjnej oraz glosy do orzeczeń Naczelnego Sądu Administracyjnego².

Przedwczesna śmierć Profesora Witolda Olszowego (zginął w wypadku samochodowym 26 października 1995 r.) przerwała tak dobrze zapowiadającą się karierę naukową i dydaktyczną. Nie zdążył wystąpić w roli promotora ukończonej już rozprawy doktorskiej. Profesor Cezary Kosikowski we wspomnieniach o swoim uczniu i przyjacielu napisał:

Lubiany powszechnie, przyciągał ludzi swoją życzliwością i tolerancją pogodnym usposobieniem. Żył krótko, lecz jakże pracowicie, z szacunkiem dla innych oraz poczuciem odpowiedzialności i troski o najbliższych ${ }^{3}$.

${ }^{2}$ Ibidem.

${ }^{3}$ Ibidem, s. 86. 


\section{Biruta Lewaszkiewicz-Petrykowska}

\section{Tomasz Pajor (1948-2012)}

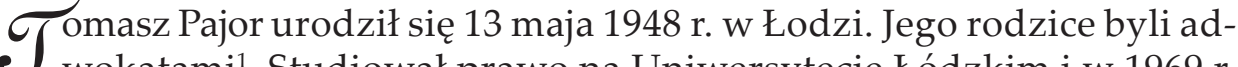
$\int$ wokatami $^{1}$. Studiował prawo na Uniwersytecie Łódzkim i w 1969 r. uzyskał stopień magistra. Od 1 października 1969 r. został zatrudniony w charakterze asystenta w Katedrze Prawa Cywilnego na Wydziale Prawa i Administracji UŁ. W Katedrze tej, przechodząc wszystkie szczeble kariery (asystent, adiunkt, docent, profesor nadzwyczajny UŁ), pracował nieprzerwanie aż do śmierci. Od 1997 r. pracami tej Katedry kierowat.

Bezpośrednio po studiach (równolegle z pracą na UŁ) odbył w latach 1970-1972 aplikację sędziowską. Egzamin sędziowski złożył w 1972 r. W sądzie jednak nigdy nie pracował. W $1990 \mathrm{r}$. został wpisany na listę adwokatów Izby Łódzkiej.

Doktoryzował się w $1978 \mathrm{r}$. na podstawie rozprawy pt. Odpowiedzialność dłużnika za niewykonanie zobowiązania (promotor prof. dr hab. B. Lewaszkiewicz-Petrykowska). Jest to praca wybitna (I nagroda na konkursie „Państwa i Prawa” w 1979 r.). Skrócona jej wersja, wydana w 1982 r. przez PWN (co w owych czasach należało do rzadkości), spotkała się z żywym zainteresowaniem i bardzo pozytywną oceną środowiska prawniczego (Nagroda Indywidualna III stopnia Ministra Szkolnictwa Wyższego). Świadczą o tym najlepiej recenzje, które ukazały się drukiem². Znaczenie omawianej monografii można najkrócej ująć następująco: dla autora stanowiła ona wspaniały start $\mathrm{w}$ twórczą pracę naukowa a dziś nadal zaliczana jest do klasyki w dziedzinie prawa zobowiązań. Ujęte w bardzo rozległej perspektywie analizy i tezy są ciagle aktualne i każdy, kto zajmuje się problematyką umów musi się z nimi zapoznać. Bez obawy przesady

${ }^{1}$ Dane biograficzne zaczerpnięto z akt osobowych przechowywanych w Archiwum UŁ.

2 J. Napierała - „Ruch Prawniczy, Ekonomiczny i Socjologiczny” 1983, nr 2, s. 272-279; A. Klein - „Państwo i Prawo” 1983, nr 2, s. 118-122; L. Kołakowska - „Zeszyty Naukowe Instytutu Badania Prawa Sądowego" 1985, nr 24, s. 289-291. 
można powiedzieć, iż przywołana monografia jest podstawową pozycją w piśmiennictwie polskim z tego zakresu.

Podkreślenia wymaga również działalność przekładowa dr. hab. T. Pajora. Jego niezwykłych zdolności jako tłumacza dowodzi świetne tłumaczenie dzieła Ch. Perelmana pt. Logika prawnicza - Nowa retoryka ${ }^{3}$.

W 1989 r. Tomasz Pajor uzyskał stopień doktora habilitowanego w zakresie prawa cywilnego i prawa prywatnego międzynarodowego (recenzentami w przewodzie habilitacyjnym byli: prof. zw. dr hab. Jan Kosik, Uniwersytet Wrocławski, prof. zw. dr hab. Józef Skąpski, Uniwersytet Jagielloński, prof. zw. dr hab. Adam Szpunar, Uniwersytet Łódzki). Stanowiąca podstawę przewodu habilitacyjnego rozprawa pt. Odpowiedzialność deliktowa w prawie prywatnym międzynarodowym ${ }^{4}$ dotyczy jednego z węzłowych zagadnień prawa kolizyjnego. Zawartość treściowa tej pracy jest bardzo bogata, znacznie obszerniejsza niż zapowiada jej tytuł. Przedmiotem analizy były bowiem wszelkiego rodzaju zobowiązania powstające ex lege wskutek wyrządzenia szkody i mające charakter samodzielny. Rozprawa, napisana na rozległej bazie prawa porównawczego, analizowała dogłębnie poglądy nauki zagranicznej na temat łączników kolizyjnych. Autor zawarł w niej nowatorskie propozycje wykładni art. 31 p.p.m. z 1965 r. Przypomnieć też warto jego wyraźne dążenie do poszukiwania i wskazania 150 prawa najściślej związanego z rozpatrywanym stosunkiem obligacyjnym. Dziś można powiedzieć, że praca ta, napisana w latach osiemdziesiątych, niezwykle trafnie wskazywała kierunek, w jakim powinna pójść, i w praktyce poszła, nauka prawa prywatnego międzynarodowego, legislatura zresztą też (vide art. 67 p.p.m. obecnie obowiązującego).

Profesor nie pisał dużo, ale jak pisał! Wszystkie prace, nawet te najmniejsze, odznaczały się niezwykłą precyzją i pogłębioną analizą. Jest rzeczą zdumiewająca, jak wiele cennych uwag i nowatorskich rozwiązań zawarł właśnie w artykułach objętościowo niewielkich, a przecież niosących w sobie głęboką treść i wielki ładunek wiedzy. Stwierdzenie to odnosi się zresztą nie tylko do prac w języku polskim, lecz także do tych napisanych w językach francuskim i angielskim.

Pobieżny nawet rzut oka na aktywność naukową Tomasza Pajora pozwala wskazać cztery dziedziny jego działalności (nie tylko pisarskiej). Są nimi: 1) prawo cywilne, w szczególności zobowiązania i odpowiedzialność cywilna, 2) prawo prywatne międzynarodowe, 3) prawo konsumenckie oraz 4) prawo europejskie. Trudno powiedzieć, która z nich wysuwała się na plan pierwszy. Niewątpliwie jednak dwa nurty występowały w niej stale, jakby równolegle, a mianowicie odpowiedzialność cywilna i pra-

\footnotetext{
${ }^{3}$ Wyd. PWN, Warszawa 1984.

${ }^{4}$ PWN, Warszawa 1989.
} 
wo kolizyjne. W ostatnich latach najwięcej uwagi poświęcił następującym grupom zagadnień: a) w ramach prawa cywilnego: odstąpieniu od umowy, roszczeniu o spełnienie świadczenia w naturze, szkodzie czysto ekonomicznej oraz pojęciu i ochronie konsumenta, b) w zakresie prawa prywatnego międzynarodowego: konwencji wiedeńskiej o międzynarodowej sprzedaży towarów, ochronie konsumenta w obrocie międzynarodowym, odpowiedzialności państwa za działania władcze w międzynarodowym obrocie prawnym. Wielopłaszczyznowość tych badań spowodowała, że np. problem pozycji konsumenta i ochrony jego praw został przez Profesora T. Pajora rozpracowany dokładnie na trzech poziomach, mianowicie prawa cywilnego, prawa kolizyjnego oraz prawa europejskiego. Był zresztą zwolennikiem stosowania jednolitego poziomu ochrony względem każdego konsumenta, również tego spoza Unii.

Nie sposób przedstawić wszystkich jego prac. Warto jednak przypomnieć niektóre z nich, w szczególności te, w których zgłaszał własne rozwiązania i pomysły. W zakresie prawa cywilnego jego ulubioną dziedzinę stanowiły kontrakty, a przede wszystkim odpowiedzialność z tytułu ich niewykonania. Świetna znajomość prawa porównawczego sprawiła, że opracowania te wskazują też na miejsce i usytuowanie rozwiązań prawa polskiego, jego wady i zalety, w mozaice przyjętych w Europie konstrukcji prawnych. Poza przywołaną już monografią dotyczącą odpowiedzialności z tytułu niewykonania zobowiązania należy wspomnieć opracowania odnoszące się do prawa odstąpienia od umowy. I tak np. warto przyjrzeć się choćby artykułowi pt. La résolution unilaterale du contrat en droit polona$i s^{5}$. Stanowi on przykład perfekcyjnej klasyfikacji typów i rodzajów prawa odstąpienia od umowy, występujących w porządkach prawnych krajów europejskich.

Jedną z cech charakterystycznych dla twórczości T. Pajora było dążenie do zapewnienia maksymalnej ochrony prawom jednostki, szczególnie zaś osobie poszkodowanej. Nic przeto dziwnego, że zabrał głos w toczącym się od lat sporze dotyczącym interpretacji przyczynienia się poszkodowanego do zaistnienia szkody - art. 362 k.c. (Uwagi o przyczynieniu się poszkodowanego do powstania szkody ${ }^{6}$ ). Zaproponował odmienne od dotychczasowych spojrzenie na to zagadnienie. Odrzucił całkowicie jako punkt wyjścia traktowanie poszkodowanego w kategoriach współsprawstwa czy też współprzyczynienia się do szkody w rozumieniu związku przyczynowego. Zgadzając się z A. Szpunarem, że przyczynienie należy

${ }^{5}$ W: Kierunki rozwoju prawa cywilnego we Francji, w Niemczech i w Polsce w perspektywie prawa europejskiego, Łódź 2008, s. 217-237.

${ }^{6}$ W: Odpowiedzialność cywilna. Księga pamiątkowa ku czci Profesora Adama Szpunara, Zakamycze 2004, s. 155-167. 
ujmować w sposób zróżnicowany, w zależności od podstawy odpowiedzialności pozwanego, wyciągnął jednak z tej konstatacji zupełnie inne wnioski. Zwracał bowiem uwagę, że „proces przeciwko osobie odpowiedzialnej na zasadzie ryzyka nie powinien przekształcić się $\mathrm{w}$ tropienie najlżejszych błędów lub nieudolności po stronie poszkodowanego"7. Jego zdaniem, dla rozwikłania tego splotu zagadnień podstawowe znaczenie ma to, że w ujęciu art. 362 k.c. przyczynienie się poszkodowanego stanowi „okoliczność ograniczającą odpowiedzialność pozwanego za wyrządzoną szkodę" ${ }^{\prime \prime}$. W konsekwencji pisał:

\begin{abstract}
Dopuszczalność i zakres tego ograniczenia wyznaczają przede wszystkim cele i zasady określające odpowiedzialność pozwanego. To w ich świetle należy oceniać współsprawcze zachowanie poszkodowanego i ustalać, czy przyczynienie zachodzi. [A dalej:] Należy przy tym odrzucić postulat jednakowego traktowania osoby odpowiedzialnej i poszkodowanego, gdyż ten ostatni za szkodę nie odpowiada, ale ją ponosi. Sytuacji stron nie powinno się zatem ujmować symetrycznie. Okoliczności uzasadniające zaostrzoną odpowiedzialność pozwanego (wina umyślna, działalność szczególnie niebezpieczna) przemawiają z reguły za stosowaniem łagodniejszych, ochronnych dla poszkodowanego kryteriów oceny jego zachowania. Przyczynienie powinno być wówczas przyjmowane w węższym, a nie szerszym zakresie9.
\end{abstract}

Konieczne wydaje się też przypomnienie pracy (jednej z ostatnich $\mathrm{w}$ dorobku) pt. Uwagi o odszkodowawczej odpowiedzialności państwa za działania władcze w międzynarodowym obrocie prawnym ${ }^{10}$. Rzecz dotyczy zagadnienia ważnego, spornego i niezwykle delikatnego, a mianowicie problemu immunitetu państwa oraz szkód wyrządzonych działaniem władczym państwa na obcym terytorium, w tym również w czasie konfliktu zbrojnego. Poglądy swoje w tej materii Tomasz Pajor wyraził w przywołanej pracy w sposób zdecydowany. Napisał,

Jak się wydaje, uznanie niezależnego charakteru roszczeń cywilnych nie powinno budzić wątpliwości. Sam fakt, że szkody zostały wyrządzone wskutek konfliktu zbrojnego nie może pozbawiać poszkodowanych ochrony ich praw indywidualnych na podstawie prawa cywilnego. Argument, że wojna, jako zorganizowane odwołanie się do przemocy, stwarza wyjątkowy stan prawny (ius in bello), który zawiesza i zastępuje prawa cywilne państw w konflikcie, pozostaje w sprzeczności z podstawowymi zasadami współczesnego prawa międzynarodowego i jako taki jest całkowicie nie do przyjęcia $^{11}$.
7 Ibidem, s. 164.
8 Ibidem.
9 Ibidem, s. 164-165.
${ }^{10}$ W: Aurea Praxis Aurea Teoria, Ksiega Pamiatkowa ku czci Profesora Tadeusza Erecińskiego, Warszawa 2011, s. 1233-1253.
11 Ibidem, s. 1252-1253. 
Wykładał zobowiązania, prawo spadkowe i prawo prywatne międzynarodowe (wykłady kursowe), a także międzynarodowe prawo handlowe oraz prawo ochrony konsumenta (wykłady specjalizacyjny). Prowadził seminarium $z$ prawa cywilnego. Studentów nie rozpieszczał, wymagał bowiem od nich rzeczy przecież niełatwej, a mianowicie myślenia. Mimo to zajęcia przez niego prowadzone cieszyły się wielkim i niesłabnącym zainteresowaniem.

Profesor Tomasz Pajor nie uchylał się nigdy od działalności organizacyjnej w Uniwersytecie Łódzkim. Poza kierowaniem Zakładem Międzynarodowego Obrotu Cywilnego (od 1990 r.) oraz Katedrą prawa Cywilnego (od roku 1997), pełnił w UŁ następujące funkcje: opiekuna praktyk studenckich 1978-1979; kierownika punktu konsultacyjnego WPiA UŁ w Sieradzu (w latach 1982-1987); członka Senatu UŁ (1979-1983); wiceprzewodniczącego Odwoławczej Komisji Dyscyplinarnej dla Studentów (1989-1990); prodziekana Wydziału Prawa i Administracji UŁ (1991-1994); członka Komisji Statutowej UŁ (1993-1996), przewodniczącego Komisji Statutowej UŁ (1996-1999).

Był niezwykle aktywny we współpracy międzynarodowej. Przez wiele lat był stałym korespondentem „Revue européenne de droit de la consommation" [Editeur: Larcier]. Brał też czynny udział w wielu międzynarodowych programach i projektach badawczych, np. w programie badawczym UE „Étude de droit comparé sur les règles des conflits de lois relatives aux testaments et successions dans les Etats Membres de l'Union Européenne" jako raporter (sprawozdawca) tematu „,rattachement objectif en droit successoral" (2003-2004). Brał też np. udział w programie badawczym UE „Settlement of Consumer Transborder Disputes”. Nie sposób tu oczywiście wyliczyć wszystkich programów i projektów.

Członek Association Henri Capitant, a w ostatnich latach przewodniczący sekcji polskiej, członek stowarzyszony (membre associé) Międzynarodowej Akademii Prawa Porównawczego (Académie Internationale de Droit comparé), członek stowarzyszony European Consumer Law Group (ECLG - przewodniczył sekcji prawa międzynarodowego prywatnego 2001-2005), brał udział w wielu kongresach międzynarodowych występując bądź to w charakterze raportera narodowego (przykładowo: kongresy prawa porównawczego organizowane przez Międzynarodową Akademię Prawa Porównawczego: Bristol - 1998, Brisbane - 2002, Utrecht - 2006, Washington - 2010) bądź sprawozdawcy generalnego (np. Le Code Civil et l'Europe Strasbourg, Conseil de l'Europe - 2004; Association Henri Capitant, Journées Brésiliennes, Rio de Janeiro - Sao Paolo, 2005). O uznaniu dla jego wiedzy i talentu najlepiej świadczy zaproszenie go w 2006 r. przez uczonych europejskich do stałego udziału w pracach elitarnej Groupe Européen du droit international privé (GEDIP). Był wybitnym uczonym, 
znakomitym znawcą prawa prywatnego zarówno cywilnego, jak i międzynarodowego, szeroko znanym i uznanym w prawniczym świecie Europy. Wielokrotnie zapraszany jako professeur invité wygłaszał wykłady i prowadził zajęcia na uniwersytetach europejskich (Nantes - 1993, Aix-Marseille - 1995, Grenoble - 2003).

Swoją głęboką wiedzą i umiejętnościami służył również w sprawach publicznych. Od 1994 r. był członkiem Zespołu Ekspertów do spraw dostosowania prawa polskiego przy Komitecie Integracji Europejskiej, w latach zaś 1991-1998 doradcą ministra ds. integracji europejskiej. Opracowywał programy harmonizacji, liczne opinie o zgodności projektów ustaw z prawem europejskim. Od 2003 r. brał udział w pracach Zespołu - Komisji Kodyfikacyjnej Prawa Cywilnego przy Ministrze Sprawiedliwości - powołanego do problematyki kodyfikacji prawa prywatnego międzynarodowego. W latach 1996-1997 był stałym konsultantem zespołu ds. projektu prawa przemysłowego, w latach zaś 2001-2003 uczestniczył w pracach zespołu powołanego przez ministra skarbu do przygotowania projektu ustawy o reprywatyzacji.

Na koniec przypomnieć trzeba charakterystyczną cechę wystąpień Profesora T. Pajora. Na różnych zebraniach naukowych (seminariach, dyskusjach, konferencjach itp.) warto było śledzić jego reakcje. Zawsze bowiem wyglądało to tak - siedział cicho, słuchał kolejnych mówców, analizował... A głos zabierał tylko wtedy, gdy naprawdę miał coś do powiedzenia i wówczas w wypowiedziach jego ważne było każde słowo. Miał niebywałą zdolność i umiejętność uchwycenia samej istoty zagadnienia oraz doboru celnej argumentacji. Wypowiadał się z prostota bez efekciarstwa, precyzyjnie, rozważnie i z wielkim poczuciem odpowiedzialności. Sądy głoszone i tezy wysuwane przezeń były wyważone, przemyślane i uporządkowane, a wszystko to zawarte było w pięknej i eleganckiej formie.

Jego przedwczesne odejście, w pełni sił twórczych, oznaczało niepowetowaną stratę tak dla Uniwersytetu Łódzkiego, jak i całej polskiej nauki prawa. 


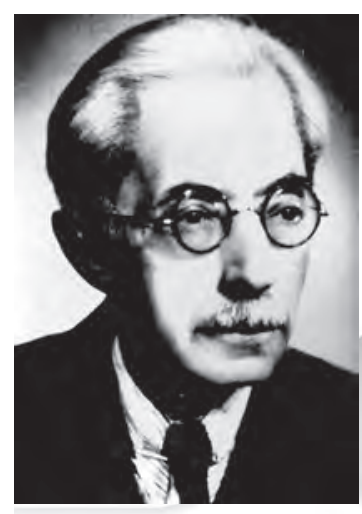

Stefan Lelental

\section{Emil Stanisław Rappaport (1877-1965)}

$\mathcal{U} \begin{aligned} & \text { rodził się } 8 \text { lipca } 1877 \text { r. w Warszawie. W latach 1888-1897 uczęszczał } \\ & \text { do V Rosyjskiego Gimnazjum w Warszawie, a w latach 1897-1901 }\end{aligned}$ studiował na Wydziale Prawa rosyjskiego Uniwersytetu w Warszawie. Od 1898 r. pracował jako główny bibliotekarz zarządu Bratniej Pomocy Studentów Uniwersytetu Warszawskiego i organizował sekcje naukowe tzw. Latającego Uniwersytetu Polskiego w mieszkaniach prywatnych inteligencji warszawskiej. Aplikację sądową przeprowadził w Rydze.

Uzupełniające studia odbywał kolejno w Paryżu (1903-1904), Berlinie (1904-1905), Londynie (1909) i ponownie w Paryżu. O słynnym „Seminarium" berlińskim prof. Franciszka von Liszta oraz o prof. Emilu Garçon z okresu studiów w Paryżu, już jako profesor Uniwersytetu Łódzkiego, E. St. Rappaport wspominał często w czasie wykładów polityki kryminalnej, historii prawa karnego, prawa karnego porównawczego i prawa karnego wykonawczego. W przypisach do wydanego w 1948 r. podręcznika z polityki kryminalnej Profesor wspomina o drukowanych notatkach wykładowych prof. F. v. Liszta, „Rechtsphilosophie” i „Kriminalpolitik”, które nigdy nie ukazały się $\mathrm{w}$ formie książkowej, a którymi przez wiele lat posiłkował się przy wykładaniu polityki kryminalnej w Towarzystwie Kursów Naukowych (1906-1916) i w Wolnej Wszechnicy Polskiej (1916-1939) w Warszawie.

W roku 1910 uzyskał dyplom Instytutu Kryminologicznego w Paryżu a na Uniwersytecie w Neuchâtel w Szwajcarii - stopień naukowy doktora praw, nostryfikowany następnie we Lwowie w 1920 r. Napisana w języku francuskim rozprawa doktorska pod tytułem Ustawa o przebaczeniu w świetle projektów francuskich ukazała się w językach francuskim i polskim (Neuchâtel 1911; Warszawa 1916).

W latach 1906-1917 wykonywał zawód adwokata. Był wówczas członkiem Koła Obrońców Politycznych, zorganizowanego przez znanego w tym czasie obrońcę w sprawach politycznych, późniejszego sędziego Sądu Najwyższego i ministra sprawiedliwości - Stanisława Patka. 
W czasie pierwszej wojny światowej E. St. Rappaport był jednym z inicjatorów akcji mającej na celu powołanie do życia sądownictwa polskiego w postaci sądów obywatelskich (1915) i sądownictwa państwowego (1917). W 1917 r. mianowany został sędzią Sądu Apelacyjnego w Warszawie z delegacją do Sądu Najwyższego. W tym charakterze uczestniczył w pierwszym posiedzeniu Izby Karnej w grudniu 1917 r.

Przewód habilitacyjny przeprowadził na Uniwersytecie Jana Kazimierza we Lwowie na podstawie monografii Bankructwo w ustawodawstwie nowoczesnym na tle porównawczym, wydanej w Warszawie w 1917 r. W latach 1920-1932 jako docent wykładał na tym Uniwersytecie prawo karne i naukę o więziennictwie.

Niezwykle ważny element w biografii Profesora stanowił jego udział w powołanej do życia ustawą z 3 czerwca 1919 r. Komisji Kodyfikacyjnej Rzeczypospolitej Polskiej, w której od 17 stycznia 1920 r. pełnił funkcję sekretarza wydziału karnego. Później, 17 maja 1920 r., Komisja Kodyfikacyjna przyznała sekretarzowi Komisji tytuł Sekretarza Generalnego, sekretarzom zaś wydziałów stanowiska członków - sekretarzy i zastępców sekretarza generalnego. Funkcję tę sprawował do zakończenia prac Komisji, których owocem był, powszechnie uznany za dzieło doskonałe - kodeks karny, wprowadzony w życie z dniem 1 września 1932 r. na mocy Rozporządzenia Prezydenta Rzeczypospolitej z dnia 11 lipca 1932 r. i obowiązujący bez istotnych zmian do 31 grudnia $1969 \mathrm{r}$. Dla wnikliwych badaczy konkretnych instytucji prawa karnego materialnego, współredagowane przez Profesora Emila Stanisława Rappaporta, publikacje Komisji Kodyfikacyjnej są trudnym do przecenienia źródłem wiedzy o aksjologii prawa karnego.

Z jego inicjatywy i przy jego dominującym udziale zostało powołane Towarzystwo Ustawodawstwa Kryminalnego, w którym dyskutowano nad projektami kodyfikacyjnymi, w tym zasadnością wprowadzenia do polskiego porządku prawnego kary śmierci. Profesor E. St. Rappaport był zawsze zdecydowanym przeciwnikiem tej kary, a gdy na ten temat wypowiadał się w czasie wykładów uniwersyteckich, czynił to w sposób tak bardzo przekonujący, że słuchacze nie mieli wątpliwości, że jest to pogląd słuszny. Towarzystwo Ustawodawstwa Kryminalnego było też miejscem dyskusji nad uzasadnieniem przygotowanego przez Profesora wniosku, złożonego w sekcji prawa karnego Komisji Kodyfikacyjnej w dniu 31 października 1930 r., w sprawie skreślenia z projektu Kodeksu karnego trzech przepisów (art. $36 \S 2,37 \S 2$ i $38 \S 2$ ) i ich przeniesienie w przyszłości do właściwego działu ustawodawstwa - Kodeksu karnego wykonawczego, a do czasu jego uchwalenia - do rozporządzenia z mocą ustawy o organizacji więziennictwa. Wniosek ten Komisja Kodyfikacyjna przyjęła do wiadomości na posiedzeniu w dniu 4 grudnia $1930 \mathrm{r}$. 
Nie ulega wątpliwości, że Profesor E. St. Rappaport był wyjątkowo zafascynowany ideą Kodeksu karnego wykonawczego, dawał temu wyraz nie tylko we wspomnianym wniosku, któremu nieco później nadał formę rozprawy naukowej (Nowy system kodyfikacji ustawodawstwa kryminalnego. Kodeks karny wykonawczy, Warszawa 1930). Z jego inicjatywy do porządku obrad III Międzynarodowego Kongresu Prawa Karnego (Palermo, kwiecień 1933 r.) wprowadzono do dyskusji sprawę kodyfikacji norm prawnych dotyczących wykonywania kar. Rezultaty dyskusji były jednak mizerne, a to z powodu - jak pisał J. Śliwowski „diametralnej różnicy poglądów uczestników, Kongres podjął rezolucję wielce kompromisową"1. Uchwalenia w 1969 r. pierwszego polskiego Kodeksu karnego wykonawczego - Profesor niestety nie doczekał.

Szczególną pozycję zajmował $\mathrm{w}$ międzynarodowym ruchu prawniczym. Był współzałożycielem i wiceprezesem Międzynarodowego Zrzeszenia Prawa Karnego (AIDP) od 1924 r. aż do końca roku 1961, kiedy złożył mandat wiceprezesa i wybrany został (nader rzadkie wyróżnienie) na honorowego członka tej bardzo wpływowej organizacji międzynarodowej. W 1957 r. w Atenach odbył się VII Kongres AIDP, w którym Profesor uczestniczył wraz z sześcioma innymi delegatami z Polski - przewodniczył sekcji III Kongresu zajmującej się „,skutkami skazania prawnokarnego”.

Kongres ateński kończył ponad dwudziestoletni okres aktywnej działalności Profesora w międzynarodowym ruchu prawniczym, w którym był wybitną indywidualnością. Należał do nielicznego grona specjalistów międzynarodowego prawa karnego, którzy jako pierwsi dążyli do stworzenia norm prawa międzynarodowego, wprowadzających kryminalizację zachowań polegających na przygotowaniu i wywołaniu agresji wojennej. W tym sensie można ich uważać - pisał J. Waszczyński - „za prekursorów tych idei, które później znalazły wyraz w tzw. zasadach norymberskich, utrwalonych w Statucie Międzynarodowego Trybunału Wojennego, który przeszedł do historii pod mianem Norymberskiego" ${ }^{2}$.

Miarą uznania dla osiągnięć organizacyjnych i naukowych Profesora w zakresie współpracy międzynarodowej w rozwoju prawa karnego i kształtowania polityki kryminalnej było zaproszenie go do współdziałania w rozwoju nowej inicjatywy kryminalno-politycznej, jaką był Ruch Obrony Społecznej. Chodzi o założone 1 stycznia 1947 r. przez genueńskiego adwokata Filippo Gramatica Stowarzyszenie Międzynarodowej Ochrony Społecznej (Societé internationale de Défence Sociale), które

1 J. Śliwowski, Narodziny Prawa Penitencjarnego, „Gazeta Sądowa Warszawska” 1934, nr 45, s. 663.

2 J. Waszczyński, Emil Stanisław Rappaport (1877-1965), „Zeszyty Naukowe Uniwersytetu Łódzkiego" 1966, Nauki Humanistyczno-Społeczne, ser. I, z. 47, s. 140. 
zaczęło wydawać własne czasopismo naukowe „Rivista di Difesa Sociale" (kwartalnik). Profesor E. St. Rappaport, jako jeden z wielu wybitnych uczonych, został członkiem korespondentem tego czasopisma ${ }^{3}$. W $1954 \mathrm{r}$. na III Kongresie w Atenach zaocznie wybrano Profesora na członka Rady Dyrekcyjnej, będącej najważniejszym, 18-osobowym organem Stowarzyszenia, a wybór ten ponawiano na kolejnych Kongresach SiDS: IV w 1956 r. w Mediolanie; V - w 1958 r. w Sztokholmie i VI - w 1961 w Belgradzie. Problematyka doktryn i ruchu obrony społecznej była podmiotem zainteresowania $\mathrm{w}$ środowisku łódzkim na seminariach działającej $\mathrm{w}$ latach 1948-1952 Katedrze Polityki Kryminalnej i Prawa Karnego Porównawczego. Profesor E. St. Rappaport był kierownikiem tej Katedry; nie ukrywał przy tym rozczarowania stanowiskiem ówczesnych władz Zrzeszenia Prawników Polskich, które nie uważały za właściwe traktować SiDS na równi z AIDP. Oficjalna delegacja polska wzięła udział dopiero w VI Kongresie. Wcześniej, z własnej inicjatywy, na Kongresie w Sztokholmie byli doc. Stanisław Pławski - kierownik Katedry Prawa Karnego na Wydziale Prawa UŁ i mgr Henryka Cybulska - sędzia Sądu dla Nieletnich w Łodzi.

Działalność w AIDP i SiDS nie wyczerpywała aktywności Profesora na forum międzynarodowym. W okresie międzywojennym był prezesem Polskiej Komisji Współpracy Prawniczej Międzynarodowej (1927-1939). W latach 1928-1939 był również wiceprezesem Biura Międzynarodowego Unifikacji Prawa Karnego. W roku 1925 został delegatem rządu polskiego w Międzynarodowej Komisji Karnej i Penitencjarnej, od 1933 r. korespondentem francuskiego ministra sprawiedliwości.

Represjonowany w czasie okupacji, w latach 1940-1941 więziony był na Pawiaku, a następnie w więzieniu mokotowskim; 2 września 1944 r. został wraz z żoną Justyną wysiedlony z Warszawy w okolice Końskich (Petrykozy, Gowarczów).

Po wyzwoleniu do Warszawy już nie powrócił. W kwietniu $1945 \mathrm{r}$. przybył do Łodzi i na stałe związał się z - istniejącym już faktycznie od marca 1945 r., a formalnie powołanym do życia przez dekret z 24 maja 1945 r. - Uniwersytetem Łódzkim ${ }^{4}$.

$\mathrm{Na}$ emeryturę, decyzją ministra szkolnictwa wyższego, odszedł 30 września 1960 r. w wieku 83 lat. Z dniem 1 października 1960 r. zlikwidowano Zakład Prawa Karnego Wykonawczego.

Sięgając do własnego indeksu z okresu studiów na Wydziale Prawa UŁ ustalam, że w roku akademickim 1955/1956 Profesor E. St. Rappaport wykładał na trzecim semestrze historię prawa karnego (dwie godziny

${ }^{3}$ RDS, 1948, z. 4.

${ }^{4}$ J. Waszczyński, J. Wróblewski, Wydziat Prawa, zarys historii Wydziału, [w:] Uniwersytet Łódzki 1945-1970, red. A. Kłoskowska, Łódź 1970, s. 121. 
w tygodniu), od piątego semestru (rok akademicki 1956/1957) zacząłem uczęszczać na prowadzone przez niego seminarium z prawa karnego porównawczego (dwie godziny w tygodniu) - kontynuowane do końca czteroletnich wówczas studiów prawniczych, a przez ostatnie trzy semestry studiów, tj. szósty, siódmy i ósmy, Profesor E. St. Rappaport prowadził wykład monograficzny z zakresu polityki kryminalnej i prawa karnego wykonawczego. W 1958 r. napisałem pracę magisterską pt. Problematyka samoistnego kodeksu karnego wykonawczego i zdałem egzamin magisterski. Wykłady prowadzone przez Profesora, piszę to bez przesady, cieszyły się wielkim zainteresowaniem studentów. Duża sala wykładowa w pofabrycznym gmachu przy ul. Kopernika 55, w którym mieścił się w tamtym czasie Wydział Prawa, zawsze była pełna, a gdy brakowało miejsc, Profesor zapraszał słuchaczy na podwyższenie, wspominając, że w taki właśnie sposób zajmowali miejsca uczestnicy berlińskiego seminarium u profesora Franciszka von Liszta.

Seminaria magisterskie odbywały się w mieszkaniu prywatnym Profesora przy ul. Gdańskiej 116, w którym jeden pokój był przeznaczony wyłącznie do tego celu. Na seminarium mogło więc uczęszczać najwyżej kilkunastu studentów. Zarówno seminarzyści, jak i inni studenci doskonali wiedzieli o C. Beccarii i znali jego poglądy. Wiedzieli również, że Profesor pracuje nad przekładem jego traktatu O przestęstwach $i$ karach. Praca ta trwała przez trzy lata, została zakończona w 1957 r., a książkę wydano na początku roku $1959^{5}$. Byłem już wtedy asystentem Profesora w Zakładzie Prawa Karnego Wykonawczego, utworzonym w 1957 r. w Katedrze Zespołowej Prawa Karnego - miejscu pracy Profesora po zlikwidowaniu Katedry Polityki Kryminalnej i Prawa Karnego Porównawczego. Wraz z likwidacją tej Katedry utracił pracę na Wydziale Prawa dotychczasowy najbliższy współpracownik Profesora, sędzia dr Mikołaj Leonieni. Bez jego pomocy nie było możliwe kontynuowanie pracy nad nowym wydaniem uniwersyteckiego podręcznika z polityki kryminalnej. Podręcznik miał być wydany w 1960 r. przez Wydawnictwo Prawnicze lub Państwowe Wydawnictwo Naukowe. Profesor miał już wtedy ponad 80 lat i chociaż zachowywał wyjątkową żywotność fizyczną i sprawność intelektualna, nie miał możliwości wykonania zaplanowanej pracy bez pomocy technicznej (przepisywanie tekstu, korekta maszynopisu, dostarczanie źródeł).

Kierowanie dwuosobowym Zakładem Prawa Karnego Wykonawczego nie zaspokajało jednak aspiracji naukowych Profesora. Ześrodkowanie

${ }^{5}$ O fascynacji Profesora myślą C. Beccarii zob. S. Lelental w: Cesare Beccaria, O przestępstwach $i$ karach, Łódź 2014, s. I-XXX; tam też kompletny wykaz prac Profesora E. St. Rappaporta. 
uwagi głównie na prawie karnym wykonawczym wymagało stworzenia płaszczyzny współpracy i współdziałania z licznymi podmiotami z zewnątrz, której uniwersytecka placówka dydaktyczna nie mogła zapewnić. Utworzony w tym celu przy Zakładzie Prawa Karnego Wykonawczego „Łódzki Ośrodek Naukowo-Badawczy Zagadnień Wykonawczych Prawa Karnego" (ŁON-B) działał do końca 1961 r. Powstanie ŁON-B otwierało możliwość współpracy z Ministerstwem Sprawiedliwości, które na podstawie ustawy z 11 października 1956 r. ${ }^{6}$ przejęło więziennictwo, wcześniej pozostawało ono w zakresie działania Ministerstwa Bezpieczeństwa Publicznego, a następnie - Ministerstwa Spraw Wewnętrznych ${ }^{7}$.

Przejście więziennictwa $\mathrm{w}$ gestię ministra sprawiedliwości, nazwane przez Profesora E. St. Rappaporta „zarządzeniem wielkiej wagi"8 umożliwiło podejmowanie badań naukowych nad wykonywaniem kary pozbawienia wolności, a co najważniejsze - ożywiło ideę uregulowania tych spraw aktem prawnym rangi ustawy. Kolejne projekty ustaw oraz regulaminów więziennych, przygotowywane przez Komisję powołaną w Ministerstwie Sprawiedliwości, były konsultowane z ŁON-B. Efektem zapoczątkowanych $\mathrm{w}$ roku $1957 \mathrm{i}$ kontynuowanych w latach następnych prac kodyfikacyjnych był opublikowany w sierpniu 1967 r. projekt prawa karnego wykonawczego, z dniem 1 stycznia 1970 r. wszedł natomiast w życie Kodeks karny wykonawczy.

W datowanym na 10 marca 1960 r. fragmencie referatu w Zrzeszeniu Prawników Polskich Profesor E. St. Rappaport napisał:

odrębnego Kodeksu Karnego Wykonawczego (o który walczę od lat przeszło 35ciu) w trójsystemie Kodyfikacji prawa karnego (KK, KPK i KKW) - w mojej sędziwej starości nie spodziewam się już doczekać. Ale wierzę głęboko, że to musi nastąpić i u nas i za granicą i może nawet wcześniej niżli niektórzy „ostrożni” juryści dawnego tradycyjnego typu ów moment społeczno-prawny zaspokojenia pełni teoretycznych i praktycznych postulatów najnowszej polityki penitencjarnej (i postpenitencjarnej) sobie wyobrażają.

Profesor Emil Stanisław Rappaport otrzymał liczne wysokie odznaczenia państwowe polskie i obce: Krzyż Komandorski z Gwiazdą Orderu Odrodzenia Polski nadany w 1930 r. „za zasługi na polu nauki, organizacji i administracji sądownictwa oraz na polu reprezentowania prawnictwa polskiego na terenie międzynarodowym" - zarządzenie podpisane dnia 8 listopada 1930 r. przez Prezydenta Rzeczypospolitej I. Mościckiego

${ }^{6}$ DzU, 1956, nr 151, poz. 188.

7 Szerzej na ten temat: S. Lelental, Wykład prawa karnego wykonawczego z elementami polityki kryminalnej, Łódź 1996, s. 48-54.

${ }^{8}$ W: Dzieje ośrodka naukowego prawniczego nowego typu w Łodzi, Łódź 1962, s. 10. 
i Prezesa Rady Ministrów J. Piłsudskiego; Złoty Krzyż Zasługi (1937); Odznakę pamiątkową polskiego sądownictwa państwowego (1923); Order Odrodzenia Polski (1946); Medal Zwycięstwa i Wolności (1947); Medal 10-lecia Polski Ludowej (1955); Order Odrodzenia Polski II klasy (1957); Order francuskiej Legii Honorowej (1924; 1947); Order Gwiazdy Rumuńskiej (1926); jugosłowiański Order Świętej Sawy (1930). Tytuł członka honorowego Królewskiej Akademii w Madrycie (od 1928 r.) i Instytutu Kryminologicznego w Buenos Aires (od 1950 r.) to inne wyrazy uznania dla Profesora, którego miałem zaszczyt być uczniem, cieszyć się jego opieką i podążać droga którą mi wskazał.

Zmarł 10 sierpnia 1965 r. w Łodzi. Został pochowany na Cmentarzu Powązkowskim w Warszawie, w grobowcu rodzinnym, w którym pochowany był jego ojciec, Feliks. 



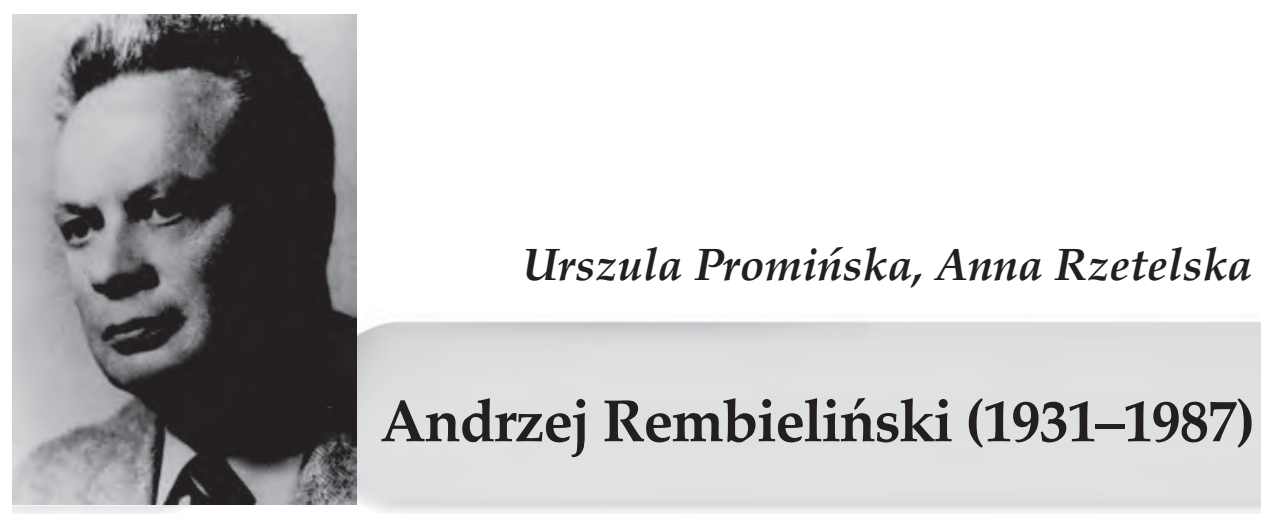

$($ ndrzej Rembieliński urodził się 9 listopada 1931 r. w Łodzi. Pochodził z rodziny, która wpisała się trwale do historii miasta. Przez całe życie był związany ze środowiskiem łódzkim. Po ukończeniu szkoły średniej rozpoczął w 1950 r. studia I stopnia na Wydziale Prawa UŁ. Po uzyskaniu stopnia magistra w 1954 r. na Wydziale Prawa UJ podjął pracę w sądownictwie. Był sędzią Sądu Wojewódzkiego dla Miasta Łodzi, kiedy w 1957 r. rozpoczął pracę jako starszy asystent w Katedrze Prawa Cywilnego UŁ. W 1963 r. uzyskał na Wydziale Prawa UŁ stopień doktora nauk prawnych na podstawie rozprawy o odpowiedzialności za wypadki samochodowe na zasadzie ryzyka, której najważniejsze fragmenty były drukowane w czasopismach. Habilitował się w 1970 r. na podstawie rozprawy pt.: Odpowiedzialność cywilna za szkode wyrzadzona przez podwładnego. Rozprawa habilitacyjna ukazała się drukiem (Warszawa 1971) i była przedmiotem bardzo pozytywnych recenzji i wypowiedzi. Do dziś powszechnie uważa się, że dzieło to stanowi fundamentalną pozycję piśmiennictwa polskiego na ten temat. Profesor A. Rembieliński od 1977 r. był kierownikiem odrębnego Zakładu Prawa Obrotu Uspołecznionego w Katedrze Prawa Cywilnego, a od 1981 r. - samodzielnej Katedry Prawa Obrotu Uspołecznionego. Poświęcił także wiele wysiłku na organizowanie nauczania prawa obrotu uspołecznionego w UMK w Toruniu. Od 1982 r. był tam kierownikiem Zakładu Prawa Obrotu Uspołecznionego. W roku 1983 r. uchwałą Rady Państwa został mu nadany tytuł profesora nadzwyczajnego. Niestety, nie sądzone mu było doczekać zasłużonego dalszego awansu.

Sfera zainteresowań naukowych Profesora Andrzeja Rembielińskiego była rozległa i niepodobna dokonać tu wszechstronnej oceny jego dorobku. Obejmowała problematykę klasycznej cywilistyki, z której wyrósł i której pozostał wierny, jak i węzłowe zagadnienia związane ze stosunkami prawnymi pomiędzy jednostkami gospodarki uspołecznionej, na które skazały go czasy, w jakich żył. W działalności naukowej Profesora A. Rem- 
bielińskiego można zatem wyodrębnić dwa główne nurty. Pierwszy z nich wypełniły przede wszystkim publikacje na temat odpowiedzialności cywilnej. Poza wskazanymi już dziełami stanowiącymi podstawę uzyskania stopni naukowych doktora i doktora habilitowanego był współautorem monografii pt. Odpowiedzialność cywilna zakładu hotelarskiego za rzeczy gości hotelowych ${ }^{1}$ oraz cenionego Komentarza do kodeksu cywilnego ${ }^{2}$. Opublikował też liczące się artykuły poświęcone odpowiedzialności cywilnej Skarbu Państwa, odpowiedzialności za wypadki w zatrudnieniu, za wypadki spowodowane przez żołnierzy w związku ze służbą wojskowa, za wypadki lotnicze, samochodowe, jak i za szkodę wyrządzoną przy leczeniu. W tym nurcie mieszczą się również liczne glosy, których wpływ na judykaturę Sądu Najwyższego jest niezaprzeczalny, i w których Profesor A. Rembieliński wykazał nieprzeciętny talent polemiczny i zrozumienie potrzeb praktyki. Nic też dziwnego, że jego wypowiedzi są do dziś przywoływane w piśmiennictwie polskim. Drugi obszar badawczy wypełniły publikacje poświęcone prawu obrotu uspołecznionego. Szczególnie cenne są jego rozprawy i artykuły dotyczące określenia granic swobody umownej w stosunkach obrotu uspołecznionego, jak również analizy stosunków pomiędzy jednostkami gospodarki uspołecznionej z perspektywy zasady jedności prawa cywilnego, której znaczenie zawsze podkreślał. 164 Przy współpracy J. Koprowskiego i A. Jaźwińskiego wydał obszerny komentarz do ogólnych warunków umów sprzedaży i dostawy (Warszawa 1979). To zakrojone na szeroką skalę dzieło zbiorowe, niezależnie od swej wartości naukowej, stanowiło wyjątkowo cenną pomoc dla praktyki. Niestety Profesor A. Rembieliński nie dożył ukazania się dzieła zbiorowego pt.: Przedsiębiorstwo państwowe i samorzad jego załogi (Warszawa 1987), którego był współautorem i koordynatorem całości. Zmiany ustrojowe, które nastąpiły niespełna dwa lata po śmierci Profesora zdezaktualizowały praktyczny walor części publikacji z zakresu obrotu pomiędzy jednostkami gospodarki uspołecznionej. Wiele z nich jest jednak dotąd cytowanych w piśmiennictwie analizującym ewolucję niektórych konstrukcji prawa polskiego, a wiele nadal wykorzystywanych ze względu na uniwersalny charakter przesłań i tez w nich zawartych. W ostatnich latach, wobec podjętych prac kodyfikacyjnych prawa cywilnego, dostrzega się potrzebę zbadania skuteczności rozwiązań dyscyplinujących uczestników obrotu gospodarczego. Bardzo rzetelne prace Profesora Andrzeja Rembielińskiego odnoszące się do tej problematyki mogą być inspirujące także dla współczesnego prawodawcy. Lektura starannie redagowanych rozpraw i artykułów Profesora dotyczących kary umownej, terminów zapłaty, obo-

\footnotetext{
${ }^{1}$ Współautorstwo z M. Nesterowiczem, Warszawa 1986.

2 Red. J. Winiarz, Warszawa 1980.
} 
wiązków stron związanych z dostarczaniem towarów czy wadliwością przedmiotu świadczenia skłania do refleksji o przewadze prawa stabilnego nad doraźnym ingerowaniem $\mathrm{w}$ porządek obrotu, o potrzebie silnych wspólnych korzeni, na których budowany jest system ocen działań wszystkich podmiotów prawa. Zatem dzieło naukowe Profesora A. Rembielińskiego obejmujące problematykę obrotu uspołecznionego ma i będzie miało nadal trwałe znaczenie. Sumując dorobek naukowy Profesora A. Rembielińskiego trzeba powiedzieć, że był autorem lub współautorem czterech monografii, trzech komentarzy, 47 artykułów i rozpraw, 33 glos, siedmiu recenzji oraz wielu innych wypowiedzi. Gruntowność analizy prawniczej, precyzja sformułowań, staranne zebranie dokumentacji naukowej, silne wyczucie potrzeb gospodarczych i społecznych, które charakteryzowały twórczość naukową Profesora, zapewniły mu poczesne miejsce $\mathrm{w}$ nauce prawa cywilnego. Aby uzyskać przybliżony obraz działalności naukowej Profesora Rembielińskiego należy podkreślić także liczne kontakty zagraniczne. Miał wykłady na uniwersytetach francuskich (Strasburg, Lyon II i III), węgierskich (Szeged) oraz w Koszycach. Jego zainteresowania prawem porównawczym znalazły odbicie niemal we wszystkich publikacjach.

Obok tak wszechstronnej działalności naukowej Profesor Andrzej Rembieliński miał bardzo poważne osiągnięcia w pracy dydaktycznej i organizacyjnej. Przez kilka lat prowadził samodzielnie wszystkie czynności związane z nauczaniem prawa obrotu uspołecznionego (wykłady, seminarium, kierowanie licznymi pracami magisterskimi). Dokonał wiele tworząc, a następnie rozwijając, silny ośrodek naukowy, uznawany w środowisku Katedr Prawa Obrotu Uspołecznionego za ważny i reprezentujący oryginalną myśl prawniczą. Promował trzech doktorów, brał udział w 13 przewodach doktorskich i dwu przewodach habilitacyjnych, był promotorem ponad 150 prac magisterskich. Ważne jest także to, że skupiał wokół siebie grono praktyków, sędziów i radców prawnych, dla których prowadził szkolenia i z którymi współpracował przy tworzeniu wielu publikacji naukowych. Profesor A. Rembieliński pełnił także wiele funkcji administracyjnych. W latach 1969-1976 był kierownikiem Studium Zaocznego Prawa, a w latach 1978-1981 prodziekanem Wydziału Prawa i Administracji UŁ. Nie uchylał się od pracy społecznej, będąc przez wiele lat przewodniczącym Rady Zakładowej ZNP. Przedstawienie działalności Profesora A. Rembielińskiego byłoby niepełne, gdyby nie wspomnieć, że był członkiem Zespołu Prawa Gospodarczego i Finansowego przy Radzie Legislacyjnej i wchodził w skład Rady Państwowego Arbitrażu Gospodarczego. Andrzej Rembieliński był wielokrotnie nagradzany i wyróżniany. Należy przede wszystkim wspomnieć o Nagrodach Indywidualnych II stopnia Ministra Nauki, Szkolnictwa Wyższego i Techniki $(1983,1987)$ 
oraz odznaczeniach (Krzyż Kawalerski Orderu Odrodzenia Polski - 1986 oraz Medal Komisji Edukacji Narodowej - 1976).

Profesor A. Rembieliński zmarł po heroicznej walce z nieuleczalną chorobą. Odszedł licząc niespełna 56 lat, w pełni sił twórczych, w okresie bujnego rozwoju swej działalności zawodowej. Jego przedwczesna śmierć wzbudziła głęboki żal wśród kolegów i współpracowników. Profesor Adam Szpunar ze wzruszeniem wspominał:

Los tak zrządził, że nauczyciel pisze o swym utalentowanym uczniu. Chciałbym, żeby wywody te były wyrazem mej pamięci i przywiązania do uczonego, którego działalność naukowa, dydaktyczną oraz organizacyjną uważnie śledziłem³.

Dziś wspominamy Profesora Andrzeja Rembielińskiego nie tylko jako uczonego i dydaktyka, ale także jako prawego, życzliwego i wyrozumiałego człowieka. Był bardzo pracowity, obowiązkowy, punktualny, pedantycznie staranny w źródłowym przygotowaniu własnej pracy naukowej i zajęć ze studentami. Z sentymentem odtwarzamy wspólne wyjazdy na konferencje, w czasie których mogłyśmy poznać inne zainteresowania, fantazję i poczucie humoru Profesora. Mogłyśmy także obserwować, jak był towarzyski i powszechnie lubiany w środowisku akademickim. Z kolegami z innych ośrodków uniwersyteckich, zwłaszcza z Torunia, Lublina i Warszawy, przetrwały do dzisiaj nasze serdeczne kontakty, którym wiele lat temu Profesor patronował. Przebyłyśmy z Profesorem Andrzejem Rembielińskim ważny dla nas etap akademickiej drogi zawodowej, a także wiele dobrych chwil, które zostają w pamięci na zawsze.

Profesor Andrzej Rembieliński spoczywa w Łodzi, na Cmentarzu Katolickim pw. św. Franciszka przy ul. Rzgowskiej.

3 "Acta Universitatis Lodziensis" 1990, Folia Iuridica 44; ten tom zeszytów naukowych UŁ był pośmiertną księgą pamiątkową ku czci Profesora Andrzeja Rembielińskiego; zob. też wspomnienie prof. A. Szpunara opublikowane w „Państwie i Prawie” 1987, z. 11, s. 90-92. 


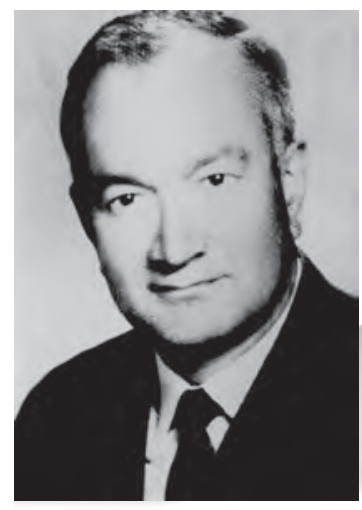

Piotr Daranowski

\section{Zbigniew Rotocki (1920-1978)}

Cbigniew Rotocki urodził się 8 lutego 1920 r. w Lublinie ${ }^{1}$. Po uzyskaOniu świadectwa dojrzałości w maju 1938 r., odbywał służbę wojskową w formule dywizyjnego kursu podchorążych rezerwy przy 77. pułku piechoty w Lidzie. Po roku służby został przydzielony do 85. pułku piechoty, w szeregach którego brał udział w kampanii wrześniowej 1939 r. - w bitwie pod Piotrkowem i w obronie Modlina. W czasie wojny, mieszkając w Warszawie, był dwukrotnie aresztowany w ulicznej łapance, ratował się ucieczka, w tym z pociągu transportującego więźniów z warszawskiego Pawiaka do obozu w Majdanku (w styczniu 1943 r.). W roku 1945 wstąpił w szeregi Wojska Polskiego. W jego II Armii w randze podporucznika zajmował kolejno stanowiska: tłumacza w sztabie 11. Dywizji Piechoty, a później adiutanta dowódcy tejże Dywizji.

Zdemobilizowany na własną prośbę celem ukończenia studiów, podjął je na Wydziale Prawa Uniwersytetu Łódzkiego w roku 1945, a ukończył w roku 1949. Po uzyskaniu tytułu magistra prawa, w roku 1950 uzyskał stopień doktora nauk prawnych UŁ, broniąc pracy Zagadnienia neutralności w rozwoju historycznym. W latach 1948-1951 zajmował kolejno stanowiska zastępcy asystenta, młodszego asystenta i starszego asystenta w Katedrze Historii Prawa na Zachodzie Europy UŁ. W okresie następnych sześciu lat (1951-1957) pełnił administracyjne funkcje kierownicze poza Uniwersytetem Łódzkim. Lata 1957-1959 spędził w Paryżu na stypendium Fundacji Forda i uzyskał tytuł doktora Uniwersytetu Paryskiego po obronie pracy zatytułowanej Le rearmement de l'Allemagne Federale, a także ukończył École des Hautes Etudes Internationales i roczny kurs dla funkcjonariuszy międzynarodowych (Orientation à la Fonction Internationale). Po powrocie do kraju ponownie został zatrudniony w Uniwersytecie Łódzkim,

${ }^{1}$ Dane biograficzne zaczerpnięto z akt osobowych Z. Rotockiego przechowywanych w Archiwum UŁ. 
kolejno (od 1 czerwca 1960 r.) na stanowisku adiunkta w katedrze Prawa Międzynarodowego Publicznego, (od 21 marca 1964 r.) docenta, wreszcie (od 1 lipca 1969 r.) kierownika Katedry. Tytuł profesora nadzwyczajnego uzyskał w roku 1975.

Zainteresowania, jak i dokonania naukowe Profesora Zbigniewa Rotockiego, opisuje kilkadziesiąt pozycji bibliograficznych, w tym książki, studia, artykuły, recenzje. Szczególnie silnie eksponują jego dorobek $\mathrm{w}$ narracji polskiej nauki prawa międzynarodowego publicznego prace koncentrujące się na prawie wojennym, a zwłaszcza prawie lotniczym i prawie morza, na problemie neutralności oraz zagadnieniach historii nauki Prawa Narodów. W równoległej, do ściśle prawno-międzynarodowej, dogmatycznej narracji, niezwykle istotna jest także dokonana przez Profesora analiza stosunków politycznych w związku z zagadnieniami prawa międzynarodowego, głównie dotycząca niemieckich praktyk doby drugiej wojny światowej, jak i powojennego procesu remilitaryzacji Niemiec. Mając na uwadze te pierwsze dokonania należy wskazać nade wszystko na następujące opracowania: Polskie wytyczne z 1939 r. dotyczace bombardowania powietrznego w świetle prawa narodów ${ }^{2}$; Lotnictwo a prawo tupu w wojnie morskiej’ Neutralność wojenna w świetle Karty Narodów Zjednoczonych ${ }^{4}$, Neutralność w tradycyjnym prawie międzynarodowym ${ }^{5}$, Wspótcześni negatorzy prawa międzynarodowego $0^{6}$; pracę habilitacyjną - Prawo wizyty i rewizji - a także - zwieńczające dorobek wieloletnich badań - monografie: Wojna domowa na morzu w świetle prawa międzynarodowego (Łódź 1976) oraz Neutralność w ramach zbiorowego bezpieczeństwa (Łódź 1978). Odnotowując zaś wybitne narracje łączące oceny polityczne z prawnomiędzynarodową analiza, unikalny w narracji, nie tylko europejskiej, jest artykuł Les operations de l'aviation allemande en Pologne en 1939 à la lumière du droit international ${ }^{7}$. Do tego nurtu należą także dwie monografie dotyczące Niemiec zatytułowane Militaryzm niemiecki po pierwszej $i$ drugiej wojnie światowej ${ }^{8}$ oraz Bundeswehra 1955-1972; Geneza i prawnopolityczne aspekty powstania Bundeswehry (Warszawa 1972). Zupełnie odrębnym i unikatowym dokonaniem było wydanie, wspólnie z prof. Remigiuszem Bierzankiem, w roku 1963 Vademecum dla kapitanów statków (Warszawa 1963) - tj. opracowania zagadnień prawa morskiego zarówno pokojowego, jak i wojennego, zawierającego praktyczne wskazania wymaganych prawem

2 "Zeszyty Naukowe Uniwersytetu Łódzkiego" [dalej: ZNUŁ] 1968, ser. I, z. 57.

3 ZNUŁ, 1965, ser. I, z. 42.

${ }^{4}$ ZNUŁ, 1963, ser. I, z. 28.

5 ZNUŁ, 1973, ser. I, z. 99.

${ }^{6}$ ZNUE, 1966, ser. I, z. 44.

7 „Polish Yearbook of International Law” 1966/1967, t. I.

${ }^{8}$ W „Dzieje Najnowsze" [kwartalnik poświęcony historii XX wieku] 1969, R. 1, z. 2. 
zachowań statków handlowych w prowadzeniu żeglugi tak w sytuacjach doby pokoju, jak i wojny.

Profesor był niekonwencjonalną i z tej przyczyny barwna, nie tylko w środowisku uniwersyteckim, postacią. Niekonwencjonalną - przywołując jedynie dwa tego świadectwa - z uwagi na swą biegłą znajomość w mowie i piśmie sześciu języków obcych, tj. języków angielskiego, francuskiego, niemieckiego, portugalskiego, rosyjskiego i włoskiego, a także przypisany mu akt uelastyczniania reguł - savoir vive - kadry naukowej Wydziału. We wspomnieniach pracowników przywoływane jest - pierwsze w historii Wydziału i stanowiące precedens - zdjęcie przez Profesora Zbigniewa Rotockiego, członka Rady Wydziału, marynarki na jej posiedzeniu odbywającym się w upalny dzień czerwcowy. W chwili jego dokonania akt ten wzbudził $u$ prowadzącego obrady dziekana zdumienie i z trudem tłumione oburzenie naruszeniem 'klasycznych' reguł wydziałowego bon ton.

Towarzysząca barwności zachowań Profesora jego wiodąca cecha - otwartości i gotowości dzielenia się wiedzą - sprawiła, że kierując Katedrą przez 12 lat był promotorem niemal 300 prac magisterskich. 



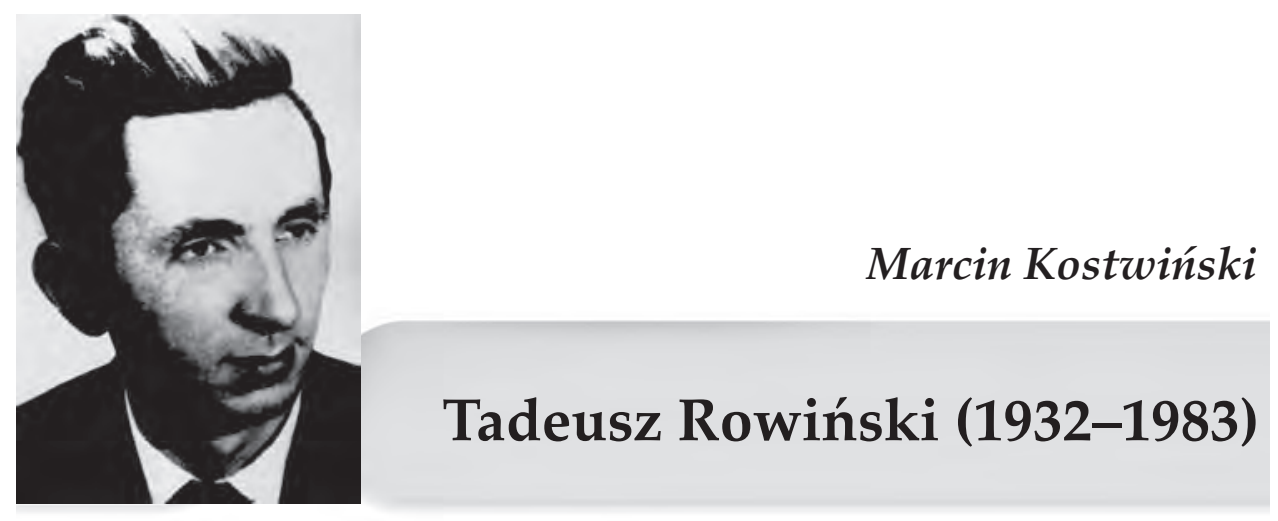

Tadeusz Czesław Rowiński, syn Zdzisława i Heleny z domu Jóźwiak, przyszedł na świat 21 sierpnia 1932 r. w Łodzi. Tutaj w 1939 r. zaczął uczęszczać do szkoły podstawowej. Okres okupacji spędził wraz z rodzicami w mieście rodzinnym, gdzie później, od roku 1946, kontynuował naukę w szkole podstawowej, w latach zaś 1949-1951 w VIII Liceum Ogólnokształcącym. Po ukończeniu szkoły średniej podjął pracę w Zakładach Przemysłu Bawełnianego im. P. Barlickiego w Łodzi w charakterze urzędnika. Po zdaniu egzaminu dojrzałości w 1953 r. rozpoczął studia prawnicze na Uniwersytecie Łódzkim.

Pracę magisterską pt. Zarzad majątkiem wspólnym matżonków przygotował w roku akademickim 1956/1957 pod kierunkiem doc. dr. Józefa Stanisława Piątowskiego w Katedrze Prawa Cywilnego. Po ukończeniu studiów w 1957 r. pozostał na uczelni jako asystent w Katedrze Postępowania Cywilnego, w roku zaś 1961 został powołany na stanowisko starszego asystenta. W tym czasie w opinii ówczesnego dziekana Tadeusz Rowiński uchodził za jednego z najlepiej zapowiadających się pomocniczych pracowników naukowych młodszego pokolenia na Wydziale Prawa UŁ. Podkreślano jego sumienność, samodzielność myślenia i uzdolnienia do pracy akademickiej.

Równolegle do prowadzonych badań naukowych, za namową kierownika Katedry Postępowania Cywilnego - doc. Mariana Lisiewskiego, w maju 1959 r. rozpoczął aplikację sądową w Sądzie Wojewódzkim dla Miasta Łodzi. Egzamin sędziowski zdał w 1961 r., zostając asesorem sądowym w okręgu Sądu Wojewódzkiego dla Miasta Łodzi. W tym samym roku zrezygnował jednak $\mathrm{z}$ pracy w sądownictwie i poświęcił się pasji naukowej.

W 1963 r. uzyskał stopień doktora nauk prawnych, po obronie rozprawy doktorskiej pt. Granice rewizji, którą przygotował pod opieką prof. dr. Władysława Siedleckiego. W tym samym roku Tadeusz Rowiński został 
awansowany na stanowisko adiunkta. W 1967 r. odbył staż naukowo-badawczy we Francji. Praca habilitacyjna nosiła tytuł Pojęcie interesu prawnego w procesie cywilnym i postępowaniu nieprocesowym, kolokwium habilitacyjne na jej podstawie złożył w grudniu $1969 \mathrm{r}$. W następnym roku powołano go na stanowisko docenta, które zajmował do chwili śmierci.

Za zasługi na polu naukowym odznaczono go Złotą Odznaką UŁ oraz Złotym Krzyżem Zasługi. Władał językami francuskim, rosyjskim, niemieckim i włoskim. Posiadał duże doświadczenie jako dydaktyk, był ceniony przez studentów i współpracowników, a nadto angażował się $\mathrm{w}$ pracę organizacyjno-administracyjną. Jako uznany specjalista z zakresu postępowania cywilnego opublikował blisko 40 prac naukowych, artykułów, glos i not polemicznych. Najważniejszym obszarem badawczym w pracy naukowej Tadeusza Rowińskiego była niewątpliwie problematyka interesu prawnego, mająca dla procesualistyki cywilnej zasadnicze znaczenie. Kompleksowe i dogłębne opracowanie tego zagadnienia stanowiło istotny wkład w rozwój rodzimej myśli prawniczej. Twórczość Tadeusza Rowińskiego po latach nie straciła na aktualności. Dzieła tego autora nadal są chętnie cytowane w pracach naukowych oraz orzeczeniach Sądu Najwyższego i sądów powszechnych.

Tadeusz Rowiński odszedł 14 marca 1983 r. po długotrwałej choro172 bie, która w ostatnich latach życia znacząco ograniczała jego pracę akademicką i uniemożliwiła pełne wykorzystanie niebagatelnego potencjału naukowego. Pozostawiony przez niego dorobek okazał się jednak ponadczasowy. 


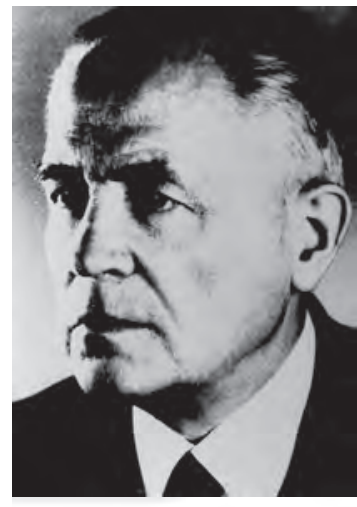

Tomasz Grzegorczyk

\section{Mieczysław Siewierski (1900-1981)}

$\mathcal{M} \mathcal{C}_{\text {ieczysław Siewierski to wybitny polski prawnik, naukowiec i dy- }}$ daktyk, a jednocześnie praktyk ${ }^{1}$. Urodził sie 22 października $1900 \mathrm{r}$. w Warszawie, ale wybuch wojny światowej sprawił, że z całą rodziną trafił do Moskwy. Tam też, w polskim gimnazjum, uzyskał świadectwo maturalne. Studia prawnicze podjąl, po powrocie do kraju w 1918 r., na Uniwersytecie Warszawskim, ale przerwał je, zgłaszając się ochotniczo w 1920 r. do wojska w czasie wojny polsko-bolszewickiej. Studia ukończył w roku 1923, a po odbytej aplikacji sądowej został sędzią śledczym w Radomiu, a następnie wiceprokuratorem Sądu Okręgowego, a później Apelacyjnego w Warszawie, od roku zaś 1937 był prokuratorem Sądu Najwyższego. Już w latach trzydziestych XX w. zajął się także pracą naukowa, wydając wspólnie z J. Nisensonem komentarze do Kodeksu postępowania karnego (1934, 1935 i 1936 r.) oraz Kodeksu karnego i prawa o wykroczeniach (1935 r.). W czasie okupacji hitlerowskiej brał udział w pracach konspiracyjnych Armii Krajowej, udzielając schronienia skoczkom spadochronowym, jako pracownik Departamentu Sprawiedliwości Delegatury Rządu, przygotował także zasady uruchomienia po wyzwoleniu sądownictwa, wspólnie zaś z prof. Stanisławem Śliwińskim projekt prawa o karaniu zbrodniarzy wojennych, opublikowany w 1943 r. jako dekret Rządu Polskiego na uchodźstwie.

Po wojnie, od kwietnia 1945 r., Mieczysław Siewierski związał się z Uniwersytetem Łódzkim, gdzie, jako zastępca profesora, prowadził wykłady, a następnie został kierownikiem Katedry Prawa Karnego Procesowego na ówczesnym Wydziale Prawno-Ekonomicznym. Wznowił wówczas także swoją działalność publikacyjna, wydając opracowany wspólnie z J. Nisensonem (który w czasie okupacji został zamordowany przez

${ }^{1}$ Dane biograficzne zostały zaczerpnięte z akt osobowych M. Siewierskiego przechowywanych w Archiwum UŁ. 
hitlerowców), uaktualniony komentarz do Kodeksu postępowania karnego. W 1945 r. objął też funkcję Pierwszego Prokuratora Sądu Najwyższego, a następnie został prokuratorem Najwyższego Trybunału Narodowego, biorąc udział, jako oskarżyciel, w historycznych już procesach zbrodniarzy wojennych Greisera, Forstera i Fischera (gubernatorów Poznania, Gdańska i Warszawy) oraz Goetha i Hoessa (komendantów obozu w Płaszowie i Auschwitz).

W roku 1950 został jednak aresztowany, a po trwającym trzy lata śledztwie, w 1953 r., sprokurowano wobec niego oskarżenie o przestępstwa z dekretu z 1946 r. o odpowiedzialności za klęskę wrześniową i faszyzację życia państwowego, skazując go na karę sześciu lat pozbawienia wolności, z darowaniem połowy tej kary na podstawie dekretu o amnestii z 1947 r. Po odzyskaniu wolności nie mógł jednak kontynuować pracy naukowej. Dopiero w 1956 r., na skutek rewizji nadzwyczajnej, Sąd Najwyższy zrehabilitował Profesora Mieczysława Siewierskiego, w tymże też roku Senat Uniwersytetu Łódzkiego reaktywował go na stanowisku zastępcy profesora w Katedrze Prawa Karnego. W 1957 r. został mianowany profesorem nadzwyczajnym, a w 1966 r. - zwyczajnym. Od roku 1959 - aż do przejścia na emeryturę w 1971 r. - kierował Katedrą Postępowania Karnego, a następnie - po reorganizacji - Zakładem Postępowania Karnego w Instytucie Prawa Karnego.

Działalność naukowa Profesora M. Siewierskiego obejmowała zarówno postępowanie karne (był tu autorem nie tylko licznych publikacji artykułowych, ale także - wspólnie z S. Kalinowskim - komentarzy do Kodeksu postępowania karnego), jak i prawo karne materialne, w którego sferze, poza publikacjami tematycznymi (odnośnie do m.in. przestępstw przeciwko porządkowi publicznemu, przeciwko działalności instytucji państwowych czy przeciwko dokumentom oraz przedawnienia karalności, form stadialnych przestępstwa, jak i pojęcia czynu nierządnego), był również współautorem (z J. Bafią i K. Mioduskim) komentarzy do Kodeksu karnego oraz prawa wykroczeń. W tej ostatniej sferze był Profesor współautorem komentarza do Kodeksu postępowania w sprawach o wykroczenia oraz autorem kilkudziesięciu publikacji artykułowych, tworząc początki tzw. łódzkiej szkoły procesowego prawa wykroczeń. Był również współautorem (z J. Tylmanem i M. Olszewskim) jedynego wówczas w Polsce ogólnopolskiego podręcznika akademickiego do postępowania karnego Postepowanie karne w zarysie (1971 i 1974), obejmującego całokształt problematyki karnoprocesowej, od zasad tego procesu po postępowanie ze stosunków międzynarodowych, w którym opracował tak istotne kwestie, jak zasady procesu, jego przesłanki, organy procesowe, strony i dowody. Dorobek naukowy Profesora Mieczysława Siewierskiego we wskazanych wyżej dziedzinach prawa obejmuje ponad 170 publikacji, dotąd zresztą przywoływanych przez przedstawicieli 
doktryny. W świecie naukowym cieszył się wielkim autorytetem i szacunkiem, o czym świadczy fakt, że zasiadał chociażby w Radzie Naukowej Instytutu Nauk Prawnych PAN i uczestniczył w międzynarodowych kongresach prawa i procesu karnego.

W środowisku prawniczym znany był jako wyjątkowo utalentowany twórca projektów, co zostało zapamiętane jako jego osobisty wkład w prace kodyfikacyjne oraz w wiele innych aktów prawnych. „Praca nad tworzeniem prawa stała się pasją mojego życia" - napisał sam Profesor Mieczysław Siewierski w nakreślonym niegdyś życiorysie ${ }^{2}$.

Za swoje osiągnięcia, a także za walkę o niepodległość, był Profesor dwukrotnie (w 1938 i 1969 r.) odznaczony Krzyżem Oficerskim Orderu Odrodzenia Polski, otrzymał także Złote Odznaki UŁ i Zrzeszenia Prawników Polskich.

Zmarł w październiku 1981 r.

W pamięci pracowników Katedry Postępowania Karnego i Kryminalistyki Uniwersytetu Łódzkiego pozostał Profesor Mieczysław Siewierski jako człowiek wielkiej kultury, wybitny prawnik, świetny i popularny dydaktyk oraz życzliwy i serdeczny przełożony.

${ }^{2}$ Wspomnienie Magdaleny Płażewskiej i Andrzeja Siewierskiego („Gazeta Stołeczna” 2001, nr 236). 



\section{Biruta Lewaszkiewicz-Petrykowska}

\section{Adam Szpunar (1913-2002)}

C dam Szpunar urodził się 27 kwietnia 1913 r. w Krakowie. W latach 1930-1934 studiował prawo na Uniwersytecie Jagiellońskim i otrzymał dyplom magistra praw (1934 r.). W tymże 1934 r. został zatrudniony w charakterze asystenta w Katedrze Prawa Cywilnego na Wydziale Prawa UJ. Doktoryzował się w 1935 r. na podstawie rozprawy pt. Przekaz wedtug kodeksu zobowiazań (wyd. w 1937 r., promotor prof. zw. dr hab. Jan Gwiazdomorski). W roku 1937 uzyskał prestiżowe stypendium Funduszu Kultury Polskiej. Umożliwiło mu ono roczny pobyt w Paryżu (1937/1938) poświęcony na prowadzenie badań. Uczestniczył tam w seminariach i słuchał wykładów znakomitych cywilistów, jak R. Capitant, R. Demogue, J. P. Niboyet. Jednocześnie zbierał materiały do przygotowywanej rozprawy habilitacyjnej.

Równolegle od zakończenia studiów aż do września 1939 r. pracował w krakowskim oddziale Prokuratorii Generalnej Skarbu Państwa.

Wojna 1939-1945 r. przerwała pracę naukową i dydaktyczną Adama Szpunara. Podjął ją na nowo w roku 1945. Jesienią 1945 r. habilitował się na Wydziale Prawa UJ na podstawie rozprawy pt. Nadużycie prawa podmiotowego (wyd. Kraków 1947). Po habilitacji pracował na stanowisku docenta na Wydziale Prawa UJ.

We współpracy z profesorem Fryderykiem Zollem opracował pierwszy zwięzły podręcznik obejmujący wszystkie części zunifikowanego prawa cywilnego: Prawo cywilne w zarysie, t. I, Część ogólna (1948), t. II, Prawo rzeczowe (1947) i t. III, Prawo familijne i spadkowe (1948).

Dnia 18 czerwca 1949 r. odebrał nominację na profesora nadzwyczajnego i kierownika Katedry Prawa Cywilnego Uniwersytetu Łódzkiego i od tej pory związał się ściśle z ośrodkiem łódzkim (w 1952 r. powołany na stanowisko Kierownika Zespołu Katedr Cywilistycznych; 1972-1981 dyrektor Instytutu Prawa Cywilnego - w tym czasie pozostawał też Kierownikiem Katedry Prawa Cywilnego). 
Uchwałą CKK z 30 stycznia 1958 r. otrzymał tytuł profesora zwyczajnego. Katedrą Prawa Cywilnego kierował do 1 października 1983 r, z którym to dniem przeszedł na emeryturę. Nie zerwał jednak więzów z Katedrą. Do ostatnich dni życia prowadził seminarium doktoranckie i wykład z prawa wekslowego i czekowego.

Profesor Adam Szpunar nie uchylał się nigdy od działalności organizacyjnej w Uczelni. W latach 1950-1953 był dziekanem Wydziału Prawa i Administracji, następnie w latach 1955-1956 prorektorem Uniwersytetu Łódzkiego, a wreszcie w latach 1956-1962 jego rektorem. Był pierwszym po drugiej wojnie światowej rektorem pochodzącym z wyboru. Okres jego kadencji jawi się jako czas wszechstronnego rozwoju łódzkiej uczelni. Profesor A. Szpunar objął bowiem uniwersytet w stanie kryzysu, a nadto dodatkowo zubożony na skutek zamknięcia w okresie poprzednim kierunków studiów neofilologicznych. Kierunki te (filologia angielska, germańska i klasyczna) - w rezultacie zabiegów Adama Szpunara - zostały ponownie uruchomione. Rektor A. Szpunar doprowadził do przyłączenia do UŁ Wyższej Szkoły Pedagogicznej (1956 r.) oraz Wyższej Szkoły Ekonomicznej (1961 r.). W czasie jego kadencji wybudowano i oddano do użytku społeczności akademickiej nowoczesny gmach Biblioteki Uniwersyteckiej.

178 Szczególne są zasługi Rektora A. Szpunara we wprowadzeniu na Uniwersytecie Łódzkim tradycyjnej obrzędowości i obyczajowości akademickiej. Dzięki jego staraniom wprowadzono togi i insygnia rektorskie oraz dziekańskie, wówczas też po raz pierwszy na Uniwersytecie Łódzkim odbyły się uroczyste ślubowania doktorskie. Nie stanowi przesady stwierdzenie, że to właśnie Adam Szpunar przeszczepił na grunt młodej uczelni wielowiekową tradycję akademicką.

Jako wykładowca i nauczyciel rygorystycznie przestrzegał pewnych zasad, a obowiązki swoje w tym względzie traktował niezwykle poważnie. Wykład i seminarium były „święte”, na zajęcia nie spóźniał się nigdy. Wykład zaczynał się punktualnie co do sekundy. Spóźnialscy siedzieli grzecznie pod drzwiami na korytarzu, aż do przerwy. Nikt nie ośmielał się nawet próbować wślizgnąć na salę, spotkałaby go bowiem ostra reprymenda. Inna sprawa, że nawet w takich warunkach można było spokojnie śledzić tok wykładu, a nawet robić notatki. Profesor Szpunar głos miał bowiem donośny. Mówił wyraźnie, dobitnie, w sposób bardzo jasny i uporządkowany. I choć wykładał bez mikrofonu (nie mieliśmy ich przed laty) wykład z prawa cywilnego rozbrzmiewał w całym budynku.

W seminarium magisterskim - a odbywało się ono zawsze i niezmiennie w środy - uczestniczyli wszyscy pracownicy Katedry. Panowała atmosfera swobodnej, niczym nieskrępowanej dyskusji. Spieraliśmy się nieraz ostro ( $\mathrm{ku}$ uciesze studentów). Podobnie bywało na seminarium 
doktoranckim. Profesor nigdy nie narzucał swojego punktu widzenia, choć bronił go żarliwie, a ponieważ charakteryzował go duży temperament polemiczny, niejednokrotnie czynił to w sposób niezwykle barwny. W rezultacie, prowadzone przez Profesora Adama Szpunara seminaria były wspaniałą szkołą argumentacji, samodzielnego myślenia, odwagi cywilnej i odpowiedzialności za słowo. Stanowiły modelowy wręcz przykład realizacji - w procesie nauczania - głoszonej przez Profesora zasady, że nauka rozwija się w ogniu dyskusji i poprzez ścieranie się poglądów, a nie przez uprzejme potakiwanie.

Aktywność Profesora A. Szpunara nie zamykała się tylko w murach Uniwersytetu Łódzkiego. Brał czynny udział w pracach legislacyjnych. Powołany w 1957 r. do Komisji Kodyfikacyjnej wywarł wpływ na kształt Kodeksu cywilnego obowiązującego od 1 stycznia 1965 r. aż do dziś. Najznaczniejszy był wkład A. Szpunara w opracowanie Księgi trzeciej kodeksu cywilnego „Zobowiązania”.

Zaproszony do udziału w pracach Komisji do spraw reformy prawa cywilnego stał się w latach 1986-1992 jej niezwykle aktywnym członkiem. W znacznej mierze jego pracy zawdzięczamy - wprowadzone nowelą z 28 lipca 1990 r. - precyzyjne unormowanie klauzuli rebus sic stantibus, przekazu i papierów wartościowych. Uregulowanie w kodeksie cywilnym odpowiedzialności gminy jest też jego zasługą.

Sądownictwo, notariat, adwokatura i radcy prawni regionu łódzkiego wiele mają mu do zawdzięczenia. Wygłaszał bowiem dla nich odczyty, wykładał $\mathrm{w}$ ramach szkoleń i studiów podyplomowych, pomagał $\mathrm{w}$ rozwiązywaniu problemów trudnych i wątpliwych. Był mistrzem w pisaniu glos do orzeczeń Sądu Najwyższego. Napisał ich 279, zawsze zwięzłe, klarowne, chwytające istotę problemu i prezentujące zdecydowane poglądy, silnie oddziaływały na judykaturę polską. Znaczenia działalności glosatorskiej profesora A. Szpunara dla praktyki sądów polskich nie sposób przecenić, wywarła ona bowiem nieprzemijający wpływ na interpretację i stosowanie prawa cywilnego

Postać profesora A. Szpunara jest szeroko znana zarówno w kraju, jak i poza nim. Należał on do uczonych, którzy własnym przykładem, swoją wiedzą i osobowością oddziaływali na całe środowisko naukowe. Powoływany wielokrotnie na promotora lub recenzenta rozpraw doktorskich i habilitacyjnych wywarł doniosły wpływ na warsztaty naukowe i poglądy wielu cywilistów średniego i młodszego pokolenia.

Profesor Adam Szpunar wielokrotnie reprezentował naukę polską poza granicami kraju, biorąc udział $w$ charakterze referenta generalnego lub krajowego w licznych kongresach, sympozjach i zjazdach. Był też zapraszany jako profesor invité na wielomiesięczne wykłady w uniwersytetach amerykańskich (Detroit, Yale, New Haven), francuskich (Paryż I, 
Lyon III, Strasbourg), niemieckich (Giessen) i brytyjskich (Cambridge). Przez szereg lat był profesorem na Międzynarodowym Wydziale Prawa Porównawczego (Faculté Internationale de Droit Comparé) w Strasburgu. Czynnie współpracował z wielkim wydawnictwem naukowym, jakim jest International Encyclopedia of Comparative Law, przyczyniając się do pogłębienia znajomości prawa polskiego za granicą. Był też aktywnym członkiem Société de Législation Comparée.

Dorobek naukowy Profesora Adama Szpunara jest ogromny. Jest on autorem 675 publikacji, w tym: 27 monografii i podręczników, 269 artykułów i studiów, 17 studiów w językach obcych, 279 glos oraz 83 drobniejszych opracowań i recenzji. Twórczość jego obejmuje w istocie całokształt prawa cywilnego. Znajdujemy w niej prace dotyczące części ogólnej, prawa rzeczowego, spadkowego, rodzinnego, zobowiązań, prawa ubezpieczeniowego, prawa spółek, wreszcie prawa wekslowego i czekowego.

Szczególne zasługi Profesora A. Szpunara polegają na położeniu podwalin pod polską naukę o odpowiedzialności cywilnej, której był najwybitniejszym przedstawicielem. Wkład w tę część prawa cywilnego jest wyjątkowo duży, głównie gdy chodzi o odpowiedzialność deliktową oraz problemy szkody i odszkodowania. Wystarczy przypomnieć, że w ramach tego działu opublikował 12 dużych monografii: Wina poszkodowa-

180 nego w prawie cywilnym (1971), Odszkodowanie w razie śmierci osoby bliskiej (1973), Ustalenie odszkodowania w prawie cywilnym (1975), Wynagrodzenie szkody wyniktej wskutek wypadku komunikacyjnego (1976), Odpowiedzialność osób zobowiazanych do nadzoru (1978), Ochrona dóbr osobistych (1979), Odpowiedzialność Skarbu Państwa za funkcjonariuszy (1985), Odpowiedzialność za szkody wyrzadzone przez zwierzęta i rzeczy (1985), Odpowiedzialność cywilna - Komentarz w formie glos (1997), Odszkodowanie za szkodę majątkowa (1998), Zadośćuczynienie za szkodę niemajątkowa (1999), Wynagrodzenie szkody wynikłej wskutek śmierci osoby bliskiej (2000). Jeżeli do tego doda się około stu artykułów i rozpraw poświęconych różnym problemom odpowiedzialności odszkodowawczej otrzymujemy niemal pełny system polskiego prawa odszkodowawczego. W latach dziewięćdziesiątych - odpowiadając na wyraźne zapotrzebowanie - A. Szpunar zajął się prawem papierów wartościowych, w szczególności zaś prawem wekslowym. $Z$ tego zakresu opublikował szereg artykułów i rozpraw, a przede wszystkim doskonały Komentarz do prawa wekslowego i czekowego (doczekał się on trzech wydań, ostatnie w 2001 r.). Znaczenia tych publikacji nie sposób przecenić. Przez całe lata bowiem uważano, że w warunkach demokracji ludowej nie ma potrzeby zajmowania się papierami wartościowymi. Na skutek wycofania $\mathrm{z}$ programów nauczania - w latach sześćdziesiątych - obowiązkowego wykładu z prawa wekslowego i czekowego, wytworzyła się swoista luka pokoleniowa w tym przedmiocie. Opracowania Profesora A. Szpunara 
lukę tę zapełniły, stając się nieocenioną pomocą w rozwiązywaniu konkretnych spraw i problemów. Wszystkie prace Adama Szpunara cechuje głęboki szacunek dla dorobku nauki prawa, poszukiwanie racjonalnej woli ustawodawcy i pewna niechęć do pozornie tylko rzecz ułatwiających propozycji de lege ferenda, niezwykłe wprost wyczucie potrzeb praktycznych, połączone z przeświadczeniem, że nauka odgrywa w pewnym sensie rolę służebną wobec potrzeb życia i praktyki. Wszystkie jego dzieła charakteryzuje wielka klarowność i przystępność wykładu, piękna polszczyzna i nieskazitelny styl.

Profesor Adam Szpunar był też wybitnym komparatystą, wyróżniającym się pogłębioną znajomością obcych porządków prawnych. Nigdy jednak nie traktował rozważań prawnoporównawczych jako popisu erudycji. Pisał: „Rozważania porównawcze mogą przyczynić się do zrozumienia przepisów własnego prawa, wyjaśniając genezę pytań, na które szukamy odpowiedzi". Przestrzegał jednak zawsze przed mechanicznym przenoszeniem obcych konstrukcji na grunt prawa polskiego.

Był członkiem rzeczywistym Polskiej Akademii Umiejętności, doktorem honoris causa Uniwersytetu Warszawskiego (1999 r.), odznaczono go wieloma odznaczeniami państwowymi, w tym Krzyżem Komandorskim Orderu Odrodzenia Polski.

Zmarł 3 grudnia 2003 r. w trakcie pisania kolejnej pracy. 



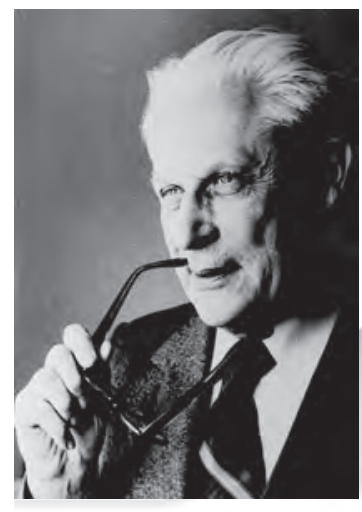

Zbigniew Góral

\section{Wacław Szubert (1912-1994) ${ }^{1}$}

Profesor Wacław Szubert wniósł szczególne zasługi w rozwój nauki pliwie zajmuje też poczesne miejsce $\mathrm{w}$ historii Wydziału Prawa i Administracji Uniwersytetu Łódzkiego, z którym był związany począwszy od 1945 r. aż do swojej śmierci.

Urodził się w 1912 r. we Włocławku. Po wybuchu pierwszej wojny światowej, w związku z deportacją ojca do Moskwy, znalazł się tam z całą rodziną. Po zakończeniu wojny uczył się w Szkole Mazowieckiej w Warszawie, a następnie (w 1934 r.) ukończył studia prawnicze na Uniwersytecie Warszawskim. W roku 1936 doktoryzował się na podstawie rozprawy pt. Dzieje ubezpieczenia na wypadek bezrobocia w Anglii. W Warszawie podjął też swoją pierwszą pracę zawodową w Dyrekcji Naczelnej Lasów Państwowych, którą zamienił na pracę naukową w Instytucie Spraw Społecznych. W okresie okupacji hitlerowskiej prowadził wykłady $w$ ramach tajnego nauczania na Wydziale Prawno-Ekonomicznym Wolnej Wszechnicy Polskiej. Był mocno zaangażowany w działalność konspiracyjną Polskiego Państwa Podziemnego. Od 1943 r. zajmował stanowisko zastępcy dyrektora Departamentu Pracy w Delegaturze Rządu RP na Kraj. Brał czynny udział w pracach koncepcyjnych dotyczących kształtu życia społeczno-gospodarczego i politycznego po wojnie. Opisał je w książce pt. Problemy pracy w koncepcjach programowych Delegatury Rzadu na Kraj (1941-1945), która pośmiertnie została wydana

${ }^{1} \mathrm{~W}$ przygotowaniu biogramu zostały wykorzystane m.in. następujące opracowania: K. Mrozowski, Nota biograficzna, [w:] W. Szubert, Problemy pracy w koncepcjach programowych Delegatury Rząu na Kraj (1941-1945) [książka wydana pośmiertnie], Łódź 2012; H. Mrozowska, Wystapienie podczas Seminarium Szubertowskiego w dniu 1 grudnia 2012 r. $w$ Łodzi, [w:] Układy zbiorowe pracy. W stulecie urodzin Profesora Wacława Szuberta, red. Z. Góral, Warszawa 2013 oraz H. Lewandowski, Wactaw Szubert (1912-1994), „Praca i Zabezpieczenie Społeczne" 1994, nr 5. 
w Wydawnictwie Uniwersytetu Łódzkiego w 2012 r. Był uczestnikiem Powstania Warszawskiego.

Od 1945 r. datuje się związek Profesora Wacława Szuberta z Uniwersytetem Łódzkim. Już 1 kwietnia tego roku został zatrudniony na stanowisku zastępcy profesora UŁ, tworząc od podstaw Katedrę Polityki Społecznej i Ustawodawstwa Społecznego, która następnie została przemianowana na Katedrę Prawa Pracy i Ubezpieczeń Społecznych. Kierował tą Katedrą aż do 1982 r., kiedy przeszedł na emeryturę. W roku 1954 został mu formalnie nadany tytuł profesora nadzwyczajnego, a od 1962 r. był profesorem zwyczajnym. Poza kierowaniem Katedrą pełnił też na Uczelni inne funkcje. Przede wszystkim był dziekanem Wydziału Prawa w latach 1953-1955 oraz 1965-1969, a więc w okresach szczególnie trudnych dla środowiska akademickiego. Pozostał w pamięci jako osoba broniąca przed represjami studentów uczestniczących w wydarzeniach marcowych w 1968 r. Jego ścisły związek z życiem naukowym Łodzi znajduje również swoje potwierdzenie w członkostwie w Łódzkim Towarzystwie Naukowym, w którym działał od 1948 r., pełniąc funkcję sekretarza i wiceprezesa. W latach 1973-1978 pracę w Uniwersytecie Łódzkim łączył z zatrudnieniem w Instytucie Pracy i Spraw Socjalnych w Warszawie, którego był dyrektorem. O pozycji naukowej Profesora Wacława Szuberta świadczą tytuły doktora honoris causa,

184 które zostały mu przyznane przez Uniwersytet Wrocławski, Uniwersytet Bordeaux I, Uniwersytet Jagielloński oraz Uniwersytet Łódzki. Był członkiem Polskiego Towarzystwa Ekonomicznego, członkiem rzeczywistym PAN, a w latach 1978-1984 oraz 1990-1992 przewodniczącym Komitetu Nauk Prawnych PAN, w latach zaś 1978-1984 wiceprzewodniczącym Komitetu Problemów Pracy i Polityki Społecznej PAN. Trzeba też wspomnieć o członkostwie w radach naukowych Centralnego Instytutu Ochrony Pracy, a także Instytutu Nauk Prawnych PAN. Przez wiele lat czynnie uczestniczył w międzynarodowym życiu naukowym. Należał do licznych towarzystw i stowarzyszeń, m.in. był członkiem Société de Législation Comparé w Paryżu, członkiem-korespondentem Międzynarodowej Akademii Prawa Porównawczego, członkiem zarządu i przewodniczącym polskiej sekcji Société Internationale de Droit du Travail et de la Sécurité Sociale, a od roku 1985 honorowym prezesem tego stowarzyszenia.

Profesor Wacław Szubert był jednym z najwybitniejszych przedstawicieli nauki prawa pracy, ubezpieczeń społecznych i polityki społecznej, o autorytecie wybiegającym znacznie poza Polskę. Przede wszystkim na tych trzech sferach działalności naukowej koncentrowały się jego badania, co znalazło wyraz w dorobku publikacyjnym, który obejmuje z górą 300 pozycji. Wiele z jego książek, studiów i artykułów do dnia dzisiejszego nie straciło na aktualności, oddziałując także na współczesnych badaczy, zwłaszcza w sferze aksjologicznej. 
W jego twórczości można wyodrębnić kilka wiodących nurtów. Pierwszemu z nich początek dały z pewnością zainteresowania związane z problematyką rozprawy doktorskiej, za sprawą których stał się wybitnym przedstawicielem polityki społecznej. Wśród podejmowanych przez niego zagadnień z tego zakresu należy wyróżnić w szczególności kwestie bezrobocia i polityki zatrudnienia. Pisał o nich zarówno z perspektywy historycznej (m.in. Studia o Fryderyku Skarbku jako ekonomiście, 1954), jak i z punktu widzenia aktualnych uwarunkowań społeczno-gospodarczych. Wielkie walory naukowe, ale zarazem dydaktyczne, miały Studia z polityki społecznej (1973). Bardzo istotne znaczenie dla kształtowania unormowań prawnych dotyczących rynku pracy w okresie przejścia od gospodarki nakazowej do gospodarki rynkowej miały jego wypowiedzi z przełomu lat osiemdziesiątych i dziewięćdziesiątych (zwłaszcza artykuł pt. Prawne zagadnienia polityki zatrudnienia z 1991 r.).

Drugim nurtem twórczości podjętym przez Profesora Wacława Szuberta już w okresie przedwojennym, a występującym ze zmienną intensywnością na różnych etapach jego kariery naukowej, były ubezpieczenia społeczne. Liczne dzieła, które ubezpieczeniom poświęcił, uczyniły zeń również i w tej dziedzinie niekwestionowany autorytet. Podejmował różnorodne zagadnienia dotyczące ubezpieczeń społecznych, poczynając od ubezpieczenia na wypadek bezrobocia, a na ubezpieczeniu emerytalnym i rentowym kończąc. Bliska była mu też teoria ubezpieczeń społecznych. Ukoronowaniem jego dokonań w tym zakresie było dzieło pt. Ubezpieczenia społeczne. Zarys systemu (1987), którego znaczenie zdecydowanie przekraczało to, co zwykle łączy się z opracowaniami podręcznikowymi. W ostatnich latach położył wielkie zasługi w kontekście badań nad historią polskich ubezpieczeń społecznych, nie zapominając jednak o potrzebie kreślenia wizji ich przyszłości (taką próbę podjął m.in. w 1991 r. w artykule pt. Refleksje nad reforma ubezpieczenia społecznego).

Przedmiotem szczególnego zainteresowania Profesora Wacława Szuberta było niewątpliwie prawo pracy. W tym zakresie uznawany jest powszechnie za jednego z trzech autorów, którzy położyli podwaliny pod rozwój tej dziedziny prawa $\mathrm{w}$ powojennej Polsce. Jego autorstwa są obszerne fragmenty książki z 1957 r. zatytułowanej Podstawowe problemy prawa pracy, która zgodnie jest uznawana za początkującą poważną refleksję naukową o prawie pracy jako odrębnej gałęzi prawa. W spuściźnie naukowej Profesora Wacława Szuberta szczególne znaczenie odegrała problematyka układów zbiorowych pracy. Napisane przez niego w 1960 r. dzieło pod takim właśnie tytułem jest zaliczane do największych osiągnięć nie tylko polskiej nauki prawa pracy. Nieco później podjął badania dotyczące ochrony życia i zdrowia pracowników. Ich kulminacją było bez wątpienia kolejne fundamentalne dzieło pt. Ochrona pracy. Studium społeczno-prawne 
(1966). W wymiarze porównawczym przemyślenia Profesora w tej dziedzinie zostały zawarte w wydanej w 1983 r. w języku angielskim książce pt. Safety and Health, stanowiącej część składową Międzynarodowej Encyklopedii Prawa Porównawczego. Dokonując przeglądu dorobku naukowego Profesora nie sposób pominąć jego Zarysu prawa pracy. Pierwsze wydanie tego podręcznika, ale również opracowania zawierającego głęboką refleksję teoretyczną, pochodzi z 1972 r., a więc z okresu poprzedzającego kodyfikację prawa pracy. Wydanie drugie ukazało się już po uchwaleniu kodeksu pracy (w 1976 r.), stanowiąc jedną z pierwszych prób nie tylko prezentacji unormowań zamieszczonych $\mathrm{w}$ tym akcie prawnym, ale również krytycznej ich oceny. W późniejszym czasie Profesor Wacław Szubert podejmował wiele szczegółowych zagadnień prawa pracy, przy czym wiele miejsca w swoich opracowaniach, zwłaszcza pochodzących z okresu transformacji ustrojowej, poświęcił związkom zawodowym i innym formom przedstawicielstwa pracowniczego, ukazując tę problematykę na szerszym tle standardów międzynarodowych. Pod koniec lat osiemdziesiątych i na początku lat dziewięćdziesiątych włączył się do dyskusji o potrzebie reformy prawa pracy w nowych warunkach ustrojowych (szczególnie doniosłe było jego opracowanie pt. Refleksje nad reforma prawa pracy z 1991 r.). Zajął się również zagadnieniami z zakresu teorii prawa pracy, 186 zwłaszcza w tekście pt. Refleksje nad modelami prawa pracy zamieszczonym w roku 1989 w „Państwie i Prawie”.

Poza przedstawionymi wyżej głównymi nurtami twórczości naukowej Profesor Wacław Szubert podejmował też zagadnienia o bardziej ogólnym charakterze. W szczególności zajmował się metodologią prawa, kulturą prawna, ideologicznymi postawami w nauce prawa czy wreszcie historią prawa i badań nad prawem. Wielkie znaczenie przywiązywał także do komparatystyki prawniczej. Publikował często w zagranicznych czasopismach. $W$ językach obcych wydał 70 różnych opracowań. Był uczestnikiem wielu międzynarodowych konferencji i seminariów naukowych, na których wygłaszał referaty bądź brał udział w dyskusji. Warto podkreślić, że na Międzynarodowym Kongresie Prawa Pracy i Zabezpieczenia Społecznego w Monachium (1978 r.), poświęconym m.in. kodyfikacji prawa pracy, pełnił funkcję referenta generalnego. W 1970 r. był głównym organizatorem Kongresu, który odbył się w Warszawie.

Profesor Wacław Szubert przez całe życie był człowiekiem nie tylko o wielkiej wrażliwości społecznej, ale także o niezłomnej postawie w sprawach zasadniczych, broniącym wartości uniwersalnych i wiernym swoim przekonaniom. Dawał temu wyraz wielokrotnie. Tak było w okresie działalności w Polskim Państwie Podziemnym, ale również w mrocznych czasach komunizmu. Nie może w związku z tym dziwić jego czynny udział w wydarzeniach związanych z narodzinami "Solidarności” 
i w późniejszych latach poprzedzających transformację ustrojową. Jako jeden z pierwszych profesorów Wydziału Prawa i Administracji wstąpił do "Solidarności”, wspierał ją swoją wiedza, pracował w Ośrodku Prac Społeczno-Zawodowych NSZZ „Solidarność", uczestniczył w przygotowaniu społecznego projektu Kodeksu pracy, a w Komitecie Nauk Prawnych PAN był jednym z inspiratorów podjęcia uchwały potępiającej internowanie działaczy opozycji demokratycznej. 



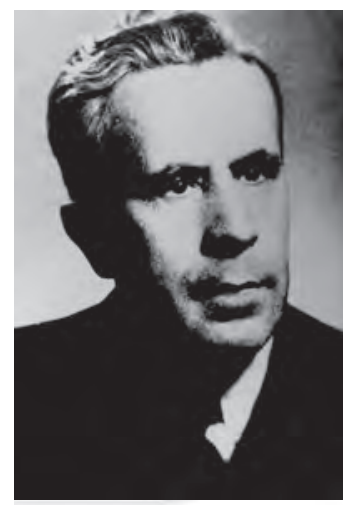

\section{Zbigniew Góral}

\section{Zdzisław Szymański (1897-1980) ${ }^{1}$}

Cdzisław Zygmunt Szymański urodził się w 1897 r. w Rudniku nad SaOnem. Po skończeniu gimnazjum w Przemyślu wstąpił do Legionów Polskich. W roku 1920 brał udział w wojnie z sowiecką Rosją. W latach następnych studiował prawo na Katolickim Uniwersytecie Lubelskim. Studia te ukończył, składając egzamin przed Państwową Komisją Egzaminacyjną przy Uniwersytecie Jana Kazimierza we Lwowie. Doktorat uzyskał w Uniwersytecie Warszawskim w 1932 r. na podstawie rozprawy Koncentracja w przemyśle ubezpieczeniowym.

W latach 1920-1922 pracował jako nauczyciel w szkołach powszechnych, a od roku 1925 do 1939 - w Ministerstwie Skarbu. Karierę ministerialną zakończył na stanowisku naczelnika wydziału i zastępcy dyrektora Państwowego Urzędu Kontroli Ubezpieczeń. Jako przedstawiciel Ministerstwa brał udział w pracach Komisji Kodyfikacyjnej - podkomisji prawa handlowego, dotyczących przygotowania polskiego prywatnego prawa ubezpieczeniowego. W latach 1938-1939 pracował też jako nauczyciel ekonomiki ubezpieczeń i prawa ubezpieczeniowego w liceum bankowo-ubezpieczeniowym w Warszawie. W okresie okupacji podjął działalność konspiracyjną w Związku Walki Zbrojnej, a następnie w Armii Krajowej. Po wojnie działał w organizacji Zrzeszenie „Wolność i Niezawisłość".

Od 1 października 1946 r. został zatrudniony w Uniwersytecie Łódzkim. Do 1948 r. zajmował stanowisko zastępcy profesora. Kierował Katedrą Teorii Spółdzielczości i prowadził wykłady z prawa ubezpieczeniowego. Jednocześnie wykładał ekonomikę ubezpieczeń w Studium Spółdzielczym UJ i w Wyższej Szkole Nauk Administracyjnych w Łodzi. W latach

${ }^{1} \mathrm{~W}$ przygotowaniu biogramu wykorzystano informacje o docencie Zdzisławie Szymańskim z jego akt osobowych przechowywanych w Archiwum Uniwersytetu Łódzkiego oraz tekst opracowania Dariusza Góreckiego (Uczeni 70-lecia: doc. dr hab. Zdzistaw Szymański, „Kronika Uniwersytetu Łódzkiego” 1995, nr 5, s. 9). 
1947-1948 pełnił funkcję członka rady nadzorczej Naukowego Instytutu Spółdzielczego w Warszawie oraz prezesa rady nadzorczej Spółdzielni Uniwersyteckiej w Łodzi. Habilitację uzyskał w 1947 r. w Uniwersytecie Jagiellońskim na podstawie pracy Prawo wielkich liczb a koncentracja w przemyśle ubezpieczeniowym.

W następstwie aresztowania związanego z wcześniejszą działalnością w antykomunistycznym podziemiu, w dniu 31 października 1948 r. skreślono go z listy pracowników UŁ. Wyrokiem Wojskowego Sądu Rejonowego został skazany na karę śmierci, a także na przepadek całego majątku i utratę praw publicznych oraz obywatelskich praw honorowych na zawsze. Karę śmierci zamieniono w następstwie prośby rodziny na 15 lat pozbawienia wolności. Z okresu pobytu $\mathrm{w}$ więzieniu pochodzą jego Wiersze więzienne 1950-1955, opublikowane pośmiertnie w 2000 r. w opracowaniu J. M. Szymańskiego. Po zwolnieniu z więzienia, w 1956 r. ponownie podjął pracę w Uniwersytecie Łódzkim (w Katedrze Prawa Pracy) kolejno jako zastępca profesora, starszy wykładowca i docent etatowy. Dnia 21 października 1960 r. Rada Wydziału Prawa Uniwersytetu Łódzkiego podjęła uchwałę o nadaniu mu stopnia naukowego docenta na podstawie pracy habilitacyjnej Ubezpieczenie na życie. 190 Uchwała ta została zatwierdzona przez ministra szkolnictwa wyższego dopiero po dwóch latach. Po przejściu na emeryturę w 1967 r. nie zaprzestał działalności dydaktycznej, prowadząc przez kilka jeszcze lat wykład z prawa ubezpieczeniowego.

Był odznaczony w okresie przedwojennym Krzyżem Walecznych (dwukrotnie), Złotym Krzyżem Zasługi, Krzyżem Kawalerskim Polonia Restituta oraz Krzyżem Niepodległości.

Dorobek naukowy Docenta Zdzisława Szymańskiego jest wielowątkowy. Niewątpliwie największe jego dokonania dotyczą prawa ubezpieczeniowego. Świadczą o tym opracowania opublikowane jeszcze w okresie przedwojennym. Wskazać tu można, poza rozprawą doktorska, choćby na książki, których był autorem bądź współautorem, np. Wiedza ubezpieczeniowa w Polsce (1928), Reasekuracja (1930), Zagadnienia nadzoru nad ubezpieczeniami majatkowymi (1934), Rzeczywistość a fikcja w ubezpieczeniach majątkowych (1935). Do zagadnień związanych z ubezpieczeniami wracał także wielokrotnie po wojnie. Wśród licznych publikacji, w których podejmował różne ich aspekty, znajdujemy książki, m.in. Ważniejsze zagadnienia $z$ dziedziny ubezpieczeń (1946), Ogólne zasady ubezpieczeń i zasady likwidacji szkód (1947), Ubezpieczenie od nieszczęśliwych wypadków (1960), Ubezpieczenie od odpowiedzialności cywilnej (1977), Prawo ubezpieczeniowe (1966, 1975, 1978), a także studia, artykuły i glosy. Zatrudnienie w Katedrze Prawa 
Pracy i współpraca z Profesorem Szubertem sprawiły, że zainteresował się również ubezpieczeniami społecznymi. Najważniejsze publikacje w tego zakresu to: Wypadki w zatrudnieniu $i$ wypadki do nich przyrównane w systemach zabezpieczenia społecznego'2, Ubezpieczenia społeczne jako instrument polityki społecznej i jego charakter prawny ${ }^{3}$ oraz Charakter prawny powszechnego ubezpieczenia społecznego pracowników ${ }^{4}$. Bliska była mu też problematyka spółdzielczości ${ }^{5}$.

\footnotetext{
2 „Praca i Zabezpieczenie Społeczne” [dalej: PiZS] 1962, nr 7.

${ }^{3}$ PiZS, 1962, nr 11.

4 „,Ruch Prawniczy, Ekonomiczny i Socjologiczny” 1967, nr 3.

${ }^{5}$ Między innymi Spótdzielczość, cz. 1-2, Łódź 1948.
} 



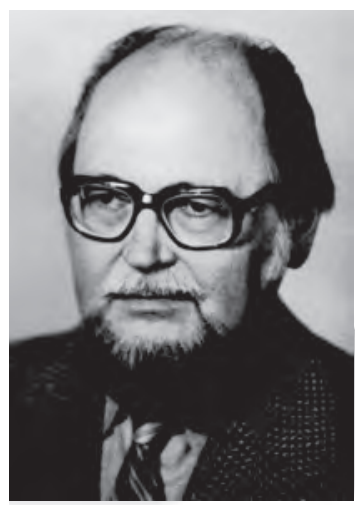

Michat Domagata

\section{Tadeusz Szymczak (1923-2014)}

$\mathcal{J}$ adeusz Szymczak urodził się 6 września 1923 r. w Łodzi1. W kwietna roboty przymusowe do Niemiec. Po powrocie do kraju natychmiast rozpoczął uzupełnianie swego wykształcenia. Jego fascynacje były bardzo zróżnicowane i znacznie odbiegały od ostatecznie wybranej dziedziny zainteresowań naukowych. Rozpoczął od ukończenia szkoły plastycznej, następnie był studentem na Wydziale Architektury Politechniki Gdańskiej. W 1946 r. był wolnym słuchaczem na kierunku matematycznym UŁ. Ostatecznie w 1947 r. rozpoczął studia prawnicze na Wydziale Prawno-Ekonomicznym UŁ. Będąc studentem IV roku prawa, 1 września 1950 r. Tadeusz Szymczak rozpoczął pracę $\mathrm{w}$ charakterze zastępcy asystenta w Katedrze Prawa Państwowego UŁ. Studia ukończył w 1951 r., po czym w listopadzie tego roku został przyjęty na aspiranturę na Wydziale Prawa Uniwersytetu im. M. Łomonosowa w Moskwie w Katedrze Prawa Państwowego, gdzie w grudniu 1954 r. uzyskał stopień kandydata nauk prawnych na podstawie rozprawy Organy władzy państwowej Polskiej Rzeczypospolitej Ludowej. W lutym 1955 r. awansował na stanowisko adiunkta w Katedrze Prawa Państwowego UŁ. Stopień doktora habilitowanego uzyskał 19 kwietnia 1964 r. na Wydziale Prawa UŁ na podstawie rozprawy Instytucja prezydenta w socjalistycznym prawie państwowym. Tytuł naukowy profesora nadzwyczajnego otrzymał w 1973 r., a profesora zwyczajnego w 1979 r. W 1993 r. Tadeusz Szymczak przeszedł na emeryturę, pracując nadal w niepełnym wymiarze godzin w Katedrze Prawa Konstytucyjnego UŁ.

Profesor Tadeusz Szymczak związał swoje zainteresowania zawodowe i naukowe z prawem konstytucyjnym zarówno polskim, jak i przede

${ }^{1}$ Nasze spojrzenie na Profesora, [w:] Zagadnienia prawa konstytucyjnego. Księga pamiatkowa ku czci Prof. Tadeusza Szymczaka, Łódź 1994, s. 3 i nast.; M. Domagała, A. Domańska, Sylwetki łódzkich uczonych. Prof. Tadeusz Szymczak, z. 85, Łódź 2008. 
wszystkim prawem porównawczym państw Europy Środkowej i Południowo-Wschodniej. Zagadnieniom tym Profesor pozostał wierny do końca swego życia. Opublikował blisko dwieście prac poświęconych tej problematyce.

Po uzyskaniu stopnia doktora nauk prawnych, Tadeusz Szymczak zajął się w szczególności instytucją prezydenta w państwach Europy Środkowej. Jest rzeczą wiadoma, że były to czasy usuwania pozostawionych jeszcze resztek systemu parlamentarno-gabinetowego, w związku z czym urząd prezydenta zastępowany był organami kolegialnymi. Zwieńczeniem tych zainteresowań była rozprawa habilitacyjna poświęcona właśnie instytucji prezydenta. Praca ta po wielu podejmowanych próbach i znacznym skróceniu tekstu ukazała się drukiem pt. Ewolucja instytucji prezydenta w socjalistycznym prawie państwowym (Łódź 1976). Badania nad instytucją prezydenta nabrały nowego wymiaru pod wpływem zmian ustrojowych, jakie zaszły z czasem w państwach Europy Środkowej i Wschodniej. Zagadnienia prawnoporównawcze i przemiany polityczno-ustrojowe w państwach tego regionu pozostały nadal głównymi nurtami badań Profesora.

Bardzo ważnym kierunkiem zainteresowań naukowych Profesora Tadeusza Szymczaka była problematyka państw federacyjnych, w szcze194 gólności Jugosławii, Czechosłowacji i Związku Radzieckiego. Trwałym efektem tych badań jest monografia Jugostawia - państwo federacyjne (Łódź 1983), jak również Ustrój polityczny ZSRR (Ossolineum, Wrocław 1978).

$\mathrm{Z}$ uwagi na swoje zainteresowania naukowe Tadeusz Szymczak uczestniczył w licznych konferencjach o zasięgu krajowym oraz międzynarodowym, w trakcie których wygłosił wiele referatów, a także brał udział w dyskusjach. Był również organizatorem tego typu konferencji. W okresie pracy w UŁ przebywał wielokrotnie na stażach zagranicznych oraz wygłaszał gościnnie referaty naukowe, m.in. w Sofii, Tbilisi, Moskwie, Pradze, Bratysławie, Koszycach, Bukareszcie, Jassy, Lipsku, Berlinie i Giessen.

Na szczególną uwagę zasługuje jego działalność dydaktyczno-wychowawcza. Prowadził wykłady z polskiego prawa konstytucyjnego, z prawa konstytucyjnego porównawczego państw obcych, seminaria magisterskie i dyplomowe dla studentów studiów stacjonarnych i zaocznych. Miał również wykłady monograficzne z zakresu wybranych problemów ustrojowych państw obcych. W sumie pod jego kierunkiem przygotowano ponad 500 prac magisterskich. Był promotorem sześciu rozpraw doktorskich. W ponad 40 przewodach doktorskich i habilitacyjnych występował $\mathrm{w}$ roli recenzenta, był również autorem wielu opinii $\mathrm{w}$ postępowaniach o nadanie tytułu naukowego. Był promotorem doktoratu honorowego UŁ dla prof. dr. Helmuta Riddera z Uniwersytetu w Giessen, a także przed- 
stawiał opinię $\mathrm{w}$ przewodach o nadanie tytułu doktora honorowego dla prof. Alfonsa Klafkowskiego oraz prof. Andrzeja Mycielskiego.

Obok działalności naukowej i dydaktycznej, profesor Tadeusz Szymczak aktywnie uczestniczył w pracach organizacyjnych Wydziału Prawa i całego Uniwersytetu Łódzkiego. W latach 1964-1969 kierował Międzywydziałowym Studium Nauk Politycznych, którego był twórcą. W latach 1971-1993 kierował Katedrą Prawa Konstytucyjnego. Pełnił również funkcję zastępcy dyrektora Instytutu Nauk o Państwie i Prawie w okresie istnienia tej jednostki na naszym Wydziale. Poza tym brał czynny udział w pracach Rady Wydziału, gdzie często wybierany był do komisji przewodów doktorskich i habilitacyjnych oraz do innych ciał kolegialnych wspomagających działalność Rady. Od 1984 r. prof. Tadeusz Szymczak przez trzy kadencje sprawował funkcję członka Senatu UŁ, był m.in. członkiem Komisji Statutowej.

Profesor Tadeusz Szymczak uczestniczył także w działalności innych instytucji naukowych. W latach 1975-1979 wchodził w skład Komitetu Nauk Politycznych Polskiej Akademii Nauk, a następnie przez trzy kadencje (1981-1993) był członkiem Komitetu Nauk Prawnych PAN. Profesor był także aktywnym uczestnikiem prac Łódzkiego Towarzystwa Naukowego, do którego należał od 1965 r., pełnił funkcję zastępcy redaktora naczelnego „Studiów Prawno-Ekonomicznych". Był również członkiem Instytutu Zachodniego im. Zygmunta Wojciechowskiego w Poznaniu oraz Międzynarodowego Stowarzyszenia Prawa Konstytucyjnego, gdzie w latach 1985-1992 pełnił funkcję członka Zarządu Polskiej Sekcji Stowarzyszenia.

W ścisłym związku z osiagnięciami naukowymi pozostaje działalność Profesora Tadeusza Szymczaka w innych dziedzinach. Przede wszystkim należy wymienić uczestnictwo w pracach Rady Legislacyjnej przy Prezesie Rady Ministrów (1984-1988). W 1989 r. był ekspertem Tymczasowej Komisji Konstytucyjnej Sejmu PRL, która opracowała projekt uchwalonej 7 kwietnia 1989 r. noweli do Konstytucji PRL. Podobną funkcję eksperta pełnił w pracach Komisji Konstytucyjnej Sejmu RP X kadencji, a od roku 1992 zapraszany był w charakterze doradcy na posiedzenia plenarne Komisji Konstytucyjnej Zgromadzenia Narodowego i jej podkomisji, dla której opracował ekspertyzy dotyczące instytucji prezydenta w projektach konstytucji. W latach 1991-1992 pełnił także funkcję sędziego Trybunału Stanu.

Profesor Tadeusz Szymczak za swoje osiągnięcia naukowe i dydaktyczne był wielokrotnie nagradzany Nagrodą Rektora UŁ oraz Ministra Edukacji Narodowej: III stopnia - 1975, II stopnia - 1977 i 1979, I stopnia - 1984 r. Ponadto był laureatem nagrody zespołowej województwa łódzkiego (1974 r.). Otrzymał także wiele odznaczeń państwowych i innych medali, 
w tym Krzyż Kawalerski Orderu Odrodzenia Polski, Krzyż Oficerski Orderu Odrodzenia Polski, Złoty Krzyż Zasługi, Medal Komisji Edukacji Narodowej, Zasłużony Nauczyciel PRL, Honorową Odznakę Miasta Łodzi, Medal w Służbie Nauki i Społeczeństwa, Medal Universitas Nicolai Copernici Facultas Iuris et Administrationis, Medal Universitas Lodziensis Merentibus oraz Medal Łódzkiego Towarzystwa Naukowego.

Profesor Tadeusz Szymczak był wybitnym specjalistą z zakresu polskiego i porównawczego prawa konstytucyjnego. W środowisku konstytucjonalistów był powszechnie uważany za twórcę łódzkiej szkoły porównawczego prawa konstytucyjnego.

Zmarł w wieku 91 lat w Łodzi, po wieloletniej chorobie, w dniu 1 października $2014 \mathrm{r}$. 


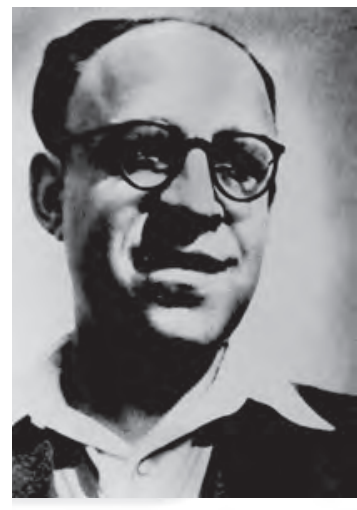

Tadeusz Szulc

\section{Stanisław Śreniowski (1912-1957)}

Stanisław Śreniowski urodził się 16 maja 1912 r. w Stryju, jako Stanisław $\int$ Weisblum, w spolonizowanej rodzinie żydowskiej. Był synem Józefa, nauczyciela języka polskiego $\mathrm{w}$ tamtejszym gimnazjum, matka zaś, Helena Frey, absolwentka lwowskiego konserwatorium w klasie fortepianu, nauczała muzyki. W latach 1922-1930 uczęszczał do szkoły powszechnej i gimnazjum w Stryju. Wówczas przyjął chrzest i zmienił nazwisko na Śreniowski ${ }^{1}$. W latach 1930-1934 odbył studia na Wydziale Prawa Uniwersytetu Jana Kazimierza we Lwowie, uczęszczał na seminarium profesora Oswalda Balzera, a po jego śmierci - na seminaria profesorów Przemysława Dąbkowskiego i Karola Koranyiego. W latach 1933-1936 zaliczył trzyletnie magisterskie Studium Ekonomiczno-Administracyjne. Służbę wojskową odbywał jako podchorąży w 19. pułku piechoty we Lwowie, odroczony ze względu na stan zdrowia. Studia naukowe kontynuował na Uniwersytecie Jagiellońskim w latach 1936-1938 pod kierunkiem profesorów: Stanisława Kutrzeby, Stanisława Estreichera i Adama Vetulaniego. Stopień doktora praw uzyskał w lutym 1939 r. na podstawie rozprawy Organizacja sejmiku halickiego (Lwów 1938), napisanej pod kierunkiem S. Kutrzeby. Od czerwca 1937 do 1 września 1939 r. odbywał praktykę w krakowskim oddziale Prokuratorii Generalnej RP jako aplikant.

We wrześniu 1939 r. zatrzymany przez Niemców w Krakowie, uciekł do Lwowa. W latach 1939-1941 pracował jako asystent profesora Dąbkowskiego w Katedrze Historii Prawa Polskiego na ukraińskim już wówczas Uniwersytecie im. Iwana Franki. W 1940 r. mianowany został starszym wykładowcą historii prawa i ustroju narodów ZSRR. 21 kwietnia tego roku wstąpił w związek małżeński z Krystyną Oppenauer. Po agresji Niemiec na ZSRR Śreniowski, z uwagi na żydowskie pochodzenie,

1 Z. Romek, Zapomniany historyk - Stanisław Śreniowski (1912-1957), „,Klio Polska. Studia i Materiały z dziejów historiografii polskiej XIX-XX w." 2012, t. VI, s. 76. 
zaczął się ukrywać. W latach 1942-1945 używał pseudonimu Stanisław Bieniarz. W marcu 1942 r. wraz z żoną przeniósł się do Krakowa, gdzie został zatrudniony jako pracownik biurowy w Zarządzie Nieruchomości. Po aresztowaniu matki, w marcu roku 1943 wyjechał do Warszawy, gdzie ukrywał się do Powstania Warszawskiego. W okresie 1943-1944 pracował w tajnym Instytucie Śląskim w Warszawie na etacie naukowym, pisząc historię ustroju Śląska. Dwukrotnie aresztowany przez policję kryminalna, został wykupiony przez żonę za pieniądze pożyczone m.in. od Ireny i Stanisława Ossowskich, znanych im jeszcze ze Lwowa. Po Powstaniu Warszawskim wywieziony transportem do Generalnej Guberni, ukrywał się w Sieprawiu w powiecie myślenickim.

Po wyparciu Niemców przez Armię Czerwoną Śreniowscy wrócili w lutym 1945 r. do Krakowa. Trudności w znalezieniu pracy wpłynęły na ich decyzję o wyjeździe do Łodzi (kwiecień 1945 r.), gdzie S. Sreniowski objął stanowisko redaktora działu popularnonaukowego w Spółdzielni Wydawniczej "Czytelnik” i równocześnie prowadził wykłady z historii ustroju Polski na Wydziale Prawno-Ekonomicznym, natomiast na Wydziale Humanistycznym z historii chłopów w Polsce. Za dom rodzinny pozostawiony w Stryju, w czerwcu 1947 r. uzyskał od Państwowego Urzędu Repatriacyjnego przydział na zajęcie piętra w poniemieckiej willi przy ul. Laurowej 2, na łódzkim Julianowie². W roku 1946 doktor Śreniowski został zastępcą profesora w Katedrze Historii Ustroju Polski na Wydziale Prawno-Ekonomicznym UŁ. W roku następnym został prorektorem Wyższej Szkoły Pedagogicznej, w latach zaś 1948-1950 był jej rektorem. Był zwolennikiem zmian politycznych zachodzących w Polsce. Wobec aktywnego zaangażowania się w promarksistowską przebudowę nauki, kariera zawodowa Śreniowskiego przebiegała bez zakłóceń ${ }^{3}$. Od 1948 r. należał do Marksistowskiego Związku Historyków. W latach 1947-1950 był kierownikiem Katedry Historii Ustroju Polski, w latach 1950-1954 organizatorem i kierownikiem Zespołu Katedr Historii Prawa, w latach zaś 1950-1957 - kierownikiem Katedry Historii Państwa i Prawa Polskiego. W styczniu $1949 \mathrm{r}$ habilitował się na podstawie pracy zatytułowanej Zbiegostwo chtopów w dawnej Polsce jako zagadnienie ustroju społecznego (Warszawa 1948). Recenzentami rozprawy byli: Natalia Gąsiorowska, Karol Koranyi, Józef Chałasiński i Zygmunt Wojciechowski. 11 listopada 1949 r. został mianowany przez prezydenta Rzeczypospolitej Polskiej, Bolesława Bieruta, profesorem nadzwyczajnym historii ustroju Polski na Uniwersytecie Łódzkim. W kwietniu 1950 r. został członkiem Wyższej Komisji Dyscyplinarnej dla Studentów UŁ. W grudniu 1953 r. powołany na rzeczoznawcę nauko-

\footnotetext{
2 Ibidem, s. 79-80.

3 Ibidem, s. 90.
} 
wego Centralnej Komisji Kwalifikacyjnej dla Pracowników Nauki, podjął pracę w II Oddziale IH PAN, opracowując pierwszy marksistowski podręcznik akademicki (t. II Historii Polski). Z chwilą powołania w Instytucie Historii PAN zespołu do badań nad historią wsi przed uwłaszczeniem, został jego kierownikiem.

Od 1948 r. był członkiem Zarządu Oddziału Łódzkiego Polskiego Towarzystwa Historycznego, w latach zaś 1949-1957 Zarządu Głównego PTH. Wchodził w skład Komitetu Redakcyjnego „Czasopisma Prawno-Historycznego". Był też członkiem Łódzkiego Towarzystwa Naukowego oraz Rady Archiwalnej.

Jego zainteresowania badawcze dotyczyły dziejów ustroju Śląska oraz sytuacji chłopów w dawnej Polsce, a także dziejów uwłaszczenia. Według profesora Jana Adamusa, któremu Śreniowski pomagał w uzyskaniu zatrudnienia na Wydziale Prawa UŁ po jego powrocie z emigracji, przeszedł on metamorfozę z osoby „o umyśle głębszym, skłonnym do rozważań metodologicznych" w początkowym okresie jego naukowej działalności, do osoby „zajmującej w licznych pracach stanowisko wyraźnie marksistowskie, czasami nawet pełne pewnego dogmatyzmu" w okresie powojennym ${ }^{4}$. Był przy tym człowiekiem despotycznym, nie tolerującym żadnego sprzeciwu, co doprowadziło np. do usunięcia z Katedry świetnie zapowiadającego się młodego naukowca dr. Henryka Grajewskiego.

W okresie pracy na Uniwersytecie Łódzkim Stanisław Śreniowski opublikował m.in.: Dzieje chłopów w Polsce. Szkice o ustroju społecznym (Warszawa 1947); Niemieckie zagadnienia ustrojowe w dobie Wiosny Ludów5; O szkołach historycznych $w$ Polsce ${ }^{6}$; Historia państwa i prawa polskiego, cz. 17; Rzeczpospolita i Galicja w latach 1772-1795. Uwagi o programie politycznym ziemiaństwa polskiego ${ }^{8}$; Historia państwa i prawa polskiego, cz. ${ }^{9}$; Uwłaszczenie chłopów w Poznańskiem ${ }^{10}$.

Profesor Stanisław Śreniowski zmarł tragicznie 11 sierpnia $1957 \mathrm{r}$. w Ustce.

${ }^{4}$ J. Adamus, Stanisław Śreniowski, „Czasopismo Prawno-Historyczne” 1958, t. X, z. 1, s. 252.

${ }^{5}$ W: W stulecie Wiosny Ludów 1848-1948, t. II, Warszawa 1948.

6 „Kwartalnik Historyczny” 1949, R. 57, s. 43-72.

7 Zagadnienia wstępne. Okres demokracji szlacheckiej (1454-1572), Łódź 1951.

8 "Przegląd Historyczny” 1952, t. XLIII, z. 1, s. 83-104.

9 Oligarchia magnacka (1572-1764), Warszawa 1953.

10 „Przegląd Nauk Historycznych i Społecznych” 1954, t. V. Pełna bibliografia prac Stanisława Śreniowskiego w: Uniwersytet Łódzki w pierwszym dziesięcioleciu. 1945-1954. Materiaty bibliograficzne, Ossolineum, Wrocław 1955, s. 146-149. 



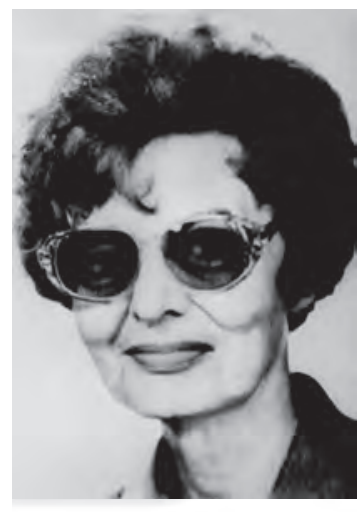

Maciej Rakowski

\section{Barbara Waldo (1925-1998) ${ }^{1}$}

Rarbara Waldo przyszła na świat 8 września 1925 r. w Warszawie, jako Scórka Stefana i Eugenii z domu Wełnickiej. W wieku dwóch lat znalazła się Augustowie, tam bowiem jej ojciec rozpoczął pracę jako sędzia śledczy przy Sądzie Okręgowym w Suwałkach, w 1935 r. został sędzią w Wydziale Hipotecznym Sądu Grodzkiego. W tym mieście Barbara Waldo ukończyła szkołę podstawową i dwie pierwsze klasy w Gimnazjum im. Grzegorza Piramowicza. We wrześniu 1939 r. jej rodzina przeniosła się do stolicy, gdzie Stefan Waldo rozpoczął praktykę adwokacką. W Warszawie, w ramach tajnego nauczania, Barbara Waldo ukończyła Gimnazjum i Liceum Królowej Jadwigi, maturę zdając w czerwcu 1944 r.

Po Powstaniu Warszawskim przebywała w obozie w Pruszkowie, później - wraz z rodziną - przez Kraków i Częstochowę trafiła do Łodzi, gdzie ojciec powrócił do praktyki adwokackiej. Już w marcu 1945 r. rozpoczęła naukę na Wydziale Prawno-Ekonomicznym Uniwersytetu Łódzkiego. Szybko jednak przerwała studia prawnicze i to aż na trzy lata. Sama różnie wyjaśniała przyczyny tego kroku. W życiorysie z 1956 r. podawała, że przeniosła się wówczas na Wydział Farmaceutyczny, natomiast w curriculum vitae z $1988 \mathrm{r}$. zamieściła informację, że naukę przerwała z powodu choroby i ze względu na stan zdrowia przez dłuższy czas przebywała $\mathrm{w}$ sanatorium akademickim $\mathrm{w}$ Zakopanem. Po powrocie na studia naukę ukończyła w ciągu trzech lat - w przyspieszonym trybie. Dyplom magistra prawa odebrała w $1951 \mathrm{r}$.

Po studiach, w latach 1952-1953, prawdopodobnie zatrudniona była w Wojewódzkiej Komisji Planowania Gospodarczego w Łodzi, a w październiku rozpoczęła pracę w Zakładzie Powszechnej Historii Państwa i Prawa UŁ. Początkowo wykonywała prace zlecone przez PAN, a od lipca

${ }^{1}$ Podstawę opracowania stanowią dokumenty zgromadzone w aktach osobowych Barbary Waldo przechowywanych w Archiwum Uniwersytetu Łódzkiego. 
1957 r. pracowała jako starszy asystent. W następnym roku ukazała się pierwsza naukowa publikacja B. Waldo².

W 1964 r. na podstawie rozprawy Niedział rodzinny w polskim prawie ziemskim do końca XV stulecia uzyskała stopień doktora nauk prawnych i odtąd pracowała jako adiunkt w Katedrze Powszechnej Historii Państwa i Prawa UŁ. Praca doktorska została oceniona wysoko, czego potwierdzeniem stała się I nagroda zdobyta w konkursie „Państwa i Prawa" w $1964 \mathrm{r}$.

Barbara Waldo uchodziła za świetnego mediewistę i znawcę średniowiecznych ksiąg sądowych, a kolejni recenzenci jej dorobku podkreślali walory jej warsztatu naukowego oraz wysoką precyzję pojęciową. Niestety - zły stan zdrowia wyraźnie utrudniał prowadzenie badań i dalsze publikacje. Jak podaje współpracujący z Barbarą Waldo Zygfryd Rymaszewski ${ }^{3}$, będące pozostałością po latach wojny choroby stanowiły poważną przeszkodę w jej pracy naukowej. Wiele lat zajęło przygotowanie rozprawy habilitacyjnej pt. Urzad starosty sadowego w Małopolsce w XV i XVI wieku. Na jej podstawie w czerwcu 1985 r. Rada Wydziału Prawa i Administracji UŁ nadała Barbarze Waldo stopień doktora habilitowanego. Monografia została wyróżniona Nagrodą III stopnia Ministra Nauki i Szkolnictwa Wyższego (1986 r.). W tym samym roku B. Waldo przeszła na emeryturę, wciąż jednak pracując na Wydziale Prawa i Administracji, od 1 października 1986 r. na etacie docenta kontraktowego. W roku 1990 została profesorem nadzwyczajnym i pracowała w Uniwersytecie Łódzkim do września $1995 \mathrm{r}$.

Barbara Waldo była ceniona przez władze uczelni. W 1961, 1963 i 1968 r. otrzymywała nagrody rektora UŁ za osiągnięcia w pracy, a w 1985 r. nagrodę II stopnia za osiągnięcia dydaktyczno-wychowawcze. Uhonorowano ją Złotą Odznaką UŁ (1983 r.) i Medalem UŁ „W służbie społeczeństwa i nauki" (1985 r.). W latach sześćdziesiątych dwukrotnie otrzymała ministerialną nagrodę za opiekę nad grupami studenckimi, a w 1983 r. wyróżniono ją Złotym Krzyżem Zasługi.

Na dorobek naukowy Barbary Waldo składają się dwie wyżej wskazane monografie oraz około dziesięć artykułów. Oprócz zagadnień związanych z niedziałem i urzędem starosty, zajmowała się także konstytucjami sejmu warszawskiego z 1658 r. oraz procesem posesoryjnym. Od października 1972 r. ta ceniona mediewistka działała w Łódzkim Towarzystwie Naukowym jako współpracownik Komisji Prawniczej Wydziału II Nauk

2 Jeszcze o opolu w Wielkopolsce, "Zeszyty Naukowe Uniwersytetu Łódzkiego" 1958, Nauki Humanistyczno-Społeczne, ser. I, z. 9, s. 225-230.

3 Z. Rymaszewski, Barbara Waldo (1925-1998), "Czasopismo Prawno-Historyczne" 1999 , t. LI, z. 1-2, s. 499. 
Historycznych i Prawnych. W czasie pracy w UŁ wypromowała ponad trzydziestu magistrantów.

Barbara Waldo była człowiekiem nauki. Nie prowadziła działalności publicznej, nie założyła rodziny. Zmarła 10 sierpnia 1998 r. i spoczęła na Cmentarzu Komunalnym na Dołach w Łodzi. 



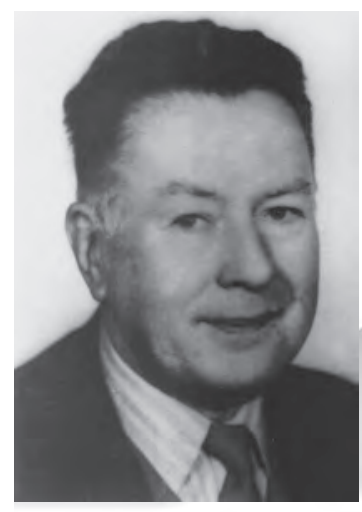

Ryszard Dębski

\section{Jan Waszczyński (1919-1997)}

Profesor dr hab. Jan Waszczyński przez 20 lat pełnił funkcję kierow$\int$ nika Katedry Prawa Karnego Uniwersytetu Łódzkiego (a w okresie działania na Wydziale Prawa UŁ instytutów - funkcję kierownika Zakładu Prawa Karnego). Objął tę funkcję w 1970 r. i pełnił ją aż do przejścia na emeryturę w dniu 1 października 1989 r. Od roku 1989 aż do śmierci 23 marca 1997 r. Profesor Jan Waszczyński kierował Zakładem Prawa Karnego Materialnego wchodzącego w skład Katedry Prawa Karnego. Profesor dr hab. Jan Waszczyński był wybitnym uczonym o szerokich zainteresowaniach badawczych i międzynarodowym autorytecie. Był autorem wielu doniosłych prac z dziedziny prawa karnego, postępowania karnego, ustroju organów ochrony prawnej, międzynarodowego prawa karnego. Był również znakomitym wykładowcą i nauczycielem akademickim związanym z Uniwersytetem Łódzkim od początku istnienia tej Uczelni. W okresie kilku dziesięcioleci pracy w Uniwersytecie Łódzkim był opiekunem i wychowawcą licznych pokoleń prawników.

Jan Aleksander Waszczyński urodził się 29 września 1919 r. w Łodzi. W Łodzi też ukończył w czerwcu 1936 r. Państwowe Gimnazjum Humanistyczne im. G. Narutowicza. W tym samym roku podjął studia na Wydziale Prawa i Nauk Społecznych Uniwersytetu im. Stefana Batorego w Wilnie. Wybuch wojny w 1939 r. przerwał studia. W latach okupacji podjął aktywną działalność partyzancką w szeregach Armii Krajowej. Już w roku 1940 wstąpił do oddziału płk. Antoniego Hedy - „Szarego" prowadzącego walkę w Górach Świętokrzyskich. Przez kilka lat wykonywał (ps. „Topola”) istotne zadania, m.in. zajmując się wywiadem umożliwiającym działania oddziału. W okresie tym ujawniły się też jego wyjątkowe umiejętności przekazywania wiedzy: Jan Waszczyński przygotowywał do matury żołnierzy oddziału, brał udział w tajnym nauczaniu.

Po zakończeniu wojny podjął ponownie studia prawnicze na Wydziale Prawa nowo utworzonego Uniwersytetu Łódzkiego. W 1946 r. uzyskał 
tytuł magistra prawa i w maju tego roku rozpoczął aplikację sądową w Sądzie Okręgowym w Łodzi. Zakończył ją egzaminem sędziowskim złożonym w czerwcu 1948 r. w Sądzie Apelacyjnym w Warszawie. W tym samym roku rozpoczął aplikację adwokacką podejmując jednocześnie, z dniem 1 grudnia 1948 r., pracę w Uniwersytecie Łódzkim jako asystent w Katedrze Prawa Karnego Procesowego kierowanej przez prof. dr. Mieczysława Siewierskiego. Przez następne lata łączył pracę na Uczelni z wykonywaniem - od 1950 aż do 1964 r. (tj. do zmiany ustawy o ustroju adwokatury) - praktyki adwokackiej. W 1958 r. uzyskał stopień naukowy kandydata nauk prawnych na podstawie rozprawy pt. Prawda materialna w postępowaniu rewizyjnym wedtug k.p.k. Stopień naukowy doktora habilitowanego otrzymał w 1964 r. przedkładając Radzie Wydziału Prawa UŁ rozprawę pt. Odszkodowanie za niestuszne skazanie i bezzasadne aresztowanie w polskim procesie karnym. Praca ta wyróżniona została nagrodą w konkursie „Państwa i Prawa”. Stanowiła ona w zakresie podjętej problematyki opracowanie pionierskie i wzbudziła szerokie zainteresowanie doktryny oraz praktyki wymiaru sprawiedliwości. Opublikowana przez Wydawnictwo Prawnicze w 1967 r. zapewniła sobie w piśmiennictwie trwała pozycję jako jedno z tych opracowań, które stanowią o dorobku polskiej powojennej literatury. Tytuł profesora nadzwyczajnego nauk prawnych Jan Waszczyński uzyskał 4 stycznia 1973 r., a 11 czerwca 1987 r. przyznano mu tytuł naukowy profesora zwyczajnego ${ }^{1}$.

Swoją kilkudziesięcioletnią, bogatą działalność naukową i dydaktyczną Profesor J. Waszczyński związał od początku z Uniwersytetem Łódzkim, w którym pełnił kolejno obowiązki asystenta (od 1948 r.), adiunkta (od 1951 r.), a następnie docenta, do połowy lat sześćdziesiątych - w Katedrze Postępowania Karnego, a od 1965 r. - w Katedrze Prawa Karnego UŁ. Od roku 1970 do 1989 kierował Katedrą Prawa Karnego UŁ (Zakładem Prawa Karnego w okresie działania na Wydziale Prawa UŁ instytutów). W latach dziewięćdziesiątych poprzedniego wieku, do końca życia w roku 1997, nadal z niezwykłą energią poświęcał się pracy naukowej i dydaktycznej w Katedrze, kierując Zakładem Prawa Karnego Materialnego, prowadząc wykłady i seminaria, opiekując się pracami naukowymi swoich uczniów.

Profesor Jan Waszczyński pełnił w Uniwersytecie Łódzkim różnorodne i liczne funkcje, wykonując je z niezwykłym zaangażowaniem i rzetelnością. Przez dwie kadencje pełnił obowiązki prodziekana Wydziału

${ }^{1}$ O działalności naukowej i dydaktycznej Profesora - por. S. Lelental, Działalność naukowa i dydaktyczna Profesora Jana Waszczyńskiego, Zagadnienia prawa karnego, "Acta Universitatis Lodziensis" 1991, Folia Iuridica nr 47, s. 3 i n. Por. także zamieszczony tam spis publikacji, s. 7 i n. 
Prawa i Administracji (od l października 1972 r. do 31 sierpnia 1975 r. i od 1 września 1975 r. do 31 sierpnia 1978 r.), a także m.in. kierownika studium doktoranckiego dla pracujących, rzecznika dyscyplinarnego dla studentów oraz rzecznika dyscyplinarnego dla pracowników nauki, przewodniczącego komisji dyscyplinarnej dla nauczycieli akademickich, opiekuna Koła Naukowego Młodych Prawników, członka szeregu komisji uczelnianych, wieloletniego prezesa Stowarzyszenia Absolwentów Wydziału Prawa i b. Wydziału Prawno-Ekonomicznego UŁ. Liczne funkcje pełnił także poza Uczelnia, będąc m.in. aktywnym działaczem Zarządu Okręgowego Zrzeszenia Prawników Polskich, przewodnicząc (w latach 19851988) Sekcji Polskiej Międzynarodowego Stowarzyszenia Prawa Karnego (AIDP), działając w Łódzkim Towarzystwie Naukowym, Towarzystwie Naukowym Prawa Karnego, uczestnicząc w pracach Centralnej Komisji Kwalifikacyjnej, w Kolegium Redakcyjnym „Palestry”, „Droit Polonais Contemporain”, „Biuletynu Głównej Komisji Badania Zbrodni Hitlerowskich w Polsce". Zupełnie szczególne są jego zasługi dla działalności Okręgowej Komisji Badania Zbrodni Hitlerowskich w Polsce, której był (od roku 1984) wieloletnim przewodniczącym.

Bogaty dorobek naukowy Profesora J. Waszczyńskiego obejmuje wiele wysoko cenionych prac zarówno z zakresu prawa karnego, jak i postępowania karnego, a także dotyczących ustroju organów ochrony prawnej, problematyki zbrodni hitlerowskich oraz międzynarodowego prawa karnego. W pierwszym okresie twórczości naukowej zasadniczym przedmiotem jego zainteresowań badawczych była problematyka postępowania karnego. W latach pięćdziesiątych i sześćdziesiątych, oprócz wspomnianych już opracowań stanowiących rozprawy doktorską i habilitacyjna, powstały liczne glosy i artykuły dotyczące m.in. postępowania rewizyjnego, uprawnień pokrzywdzonego w procesie karnym, sytuacji powoda cywilnego, postępowania dowodowego. $W$ tym nurcie zainteresowań Profesora mieszczą się zwłaszcza opublikowane w „Palestrze” prace: O tzw. kierunku rewizji w procesie karnym (1960), O zwiększenie uprawnień pokrzywdzonego w procesie karnym (1961), O dowodzie z zeznań świadka w procesie karnym - praktycznie (1966), O przygotowaniu obrony (1966) oraz artykuły zamieszczone w "Nowym Prawie": "Samoistna" rewizja powoda cywilnego (1955), Postępowanie dowodowe przed sadem wojewódzkim jako instancja rewizyjna wedtug k.p.k. (1956).

Odrębny zakres zainteresowań badawczych wiązał się z problematyką ustroju organów ochrony prawnej, stanowiącą również przedmiot wykładów Profesora prowadzonych przez szereg lat na Wydziale Prawa i Administracji UŁ. Wielu rocznikom studentów znany jest zwłaszcza wysoko ceniony skrypt pt. Ustrój organów ochrony prawnej, opublikowany w wydawnictwie UŁ (1969 - I wyd.; 1971 - II wyd.). 
Od końca lat sześćdziesiątych i początku lat siedemdziesiątych wieku XX dominującą pozycję w twórczości naukowej Profesora zajmują prace $\mathrm{z}$ zakresu prawa karnego materialnego. Dotyczą one fundamentalnych i zarazem najtrudniejszych zagadnień teoretycznych nauki o przestępstwie i nauki o karze oraz innych środkach penalnych, m.in. problematyki stopniowania winy, zamiaru ewentualnego, recydywy, systemu środków penalnych, problematyki depenalizacji. Wśród prac z tego zakresu wskazać należy zwłaszcza doniosłe artykuły związane z problematyką winy: Problem stopniowania winy w polskiej nauce prawa karnego ${ }^{2}$, Problematyka winy we włoskiej nauce prawa karnego ${ }^{3}$, a także opracowanie Stopniowanie winy w orzecznictwie Sąu Najwyższego ${ }^{4}$. Wymienić trzeba również późniejsza pracę Wina a prewencyjny aspekt kary zamieszczoną w Księdze ku czci Prof. K. Buchaty5. Wśród szczególnie ważnych, powszechnie znanych prac Profesora wskazać należy wyjątkowo często przywoływany w piśmiennictwie artykuł Jeszcze w sprawie zamiaru ewentualnego ${ }^{6}$, w którym przedstawiono nową koncepcję zamiaru wynikowego, a także opracowanie Kara śmierci we współczesnym świecie ${ }^{7}$ tudzież wcześniejsze artykuły: Prawne skutki skazania ${ }^{8}, \mathrm{O}$ „korzyści majątkowej” w prawie karnym (Próba klasyfikacji) ${ }^{9}$ i O prawnej regulacji recydywy (Uwagi de lege ferenda) ${ }^{10}$. Należy wymienić także niezmiernie cenny cykl artykułów dotyczących powrotności do przestępstwa, obejmujący zamieszczone w "Studiach Kryminologicznych, Kryminalistycznych i Penitencjarnych" prace: Ocena ilościowa zjawiska wielokrotnej recydywy w Polsce ${ }^{11}$, Recydywa wielokrotna w ustawodawstwach obcych ${ }^{12}$ dopełniony wspomnianym już artykułem O prawnej regulacji recydywy (Uwagi de lege ferenda). Wskazać trzeba też na zawierającą nowatorskie rozważania pracę $\mathrm{Z}$ zagadnień depenalizacji w prawie karnym ${ }^{13}$ czy artykuł z Księgi ku czci Prof. M. Cieślaka pt. O ustawowych przypadkach bezkarności łapownictwa ${ }^{14}$. Oprócz licznych glos Profesor J. Waszczyński publikował w „Palestrze”

2 Opublikowany w „Ruchu Prawniczym, Ekonomicznym i Socjologicznym” 1975, nr 4.

3 "Studia Prawnicze" 1976, nr 3.

4 „Palestra” 1976, nr 8-9.

5 Problemy odpowiedzialności karnej, pod red. Z. Ćwiąkalskiego, M. Szewczyk, S. Waltosia i A. Zolla, Kraków 1994.

6 „Palestra” 1977, nr 5.

7 „Palestra” 1987, nr 9.

8 "Państwo i Prawo” [dalej: PiP] 1968, nr 12.

9 PiP, 1981, nr 1.

${ }_{10}$ PiP, 1981, nr 5.

11 „Studia Kryminologiczne, Kryminalistyczne i Penitencjarne” [dalej: SKKiP] 1976, nr 5.

12 SKKiP, 1977, nr 6.

13 „Problemy Prawa Karnego" 1982, nr 7.

14 Problemy kodyfikacji prawa karnego, pod red. S. Waltosia, Kraków 1993. 
w latach 1977-1981, wspólnie z prof. M. Cieślakiem, wysoko cenione przeglądy orzecznictwa Sądu Najwyższego z zakresu prawa karnego materialnego.

Szczególną pozycję wśród prac Profesora zajmują obszerne i nader wnikliwe opracowania o charakterze monograficznym dotyczące m.in. przestępstw uszkodzenia ciała i rozstroju zdrowia, przestępstw przeciwko czci i nietykalności cielesnej, przestępstw przeciwko porządkowi publicznemu, które zamieszczone zostały w dwóch tomach zbiorowego dzieła System Prawa Karnego. Tomy tej fundamentalnej pracy współredagowane przez Profesora (jako zastępcę redaktora naczelnego I. Andrejewa) wydane zostały przez Ossolineum ${ }^{15}$.

Jako redaktor i współredaktor podjął także trud opracowania wraz z zespołem pracowników Katedry podręcznika prawa karnego, który $\mathrm{w}$ postaci skryptu $\mathrm{w}$ trzech tomach opublikowany został $\mathrm{w}$ wydawnictwie UŁ. Skrypt ten, ze względu na szczególną wartość dydaktyczną, zyskał bardzo wielu czytelników i był w części wznawiany w kilku kolejnych wydaniach ${ }^{16}$.

Kolejny nurt twórczości naukowej Profesora wiąże się z badaniami problematyki zbrodni wojennych i jego wieloletnią aktywną działalnością w Okręgowej Komisji Badania Zbrodni przeciwko Narodowi Polskiemu. Tematyce tej poświęcił bardzo wnikliwe opracowanie monograficzne Z działalności Hitlerowskiego Specjalnego Sądu Karnego w Łodzi (1939-1945)17 oraz inne prace, w których zajmował się m.in. problematyką zbrodni dokonanych w okresie okupacji na dzieciach i młodzieży, kwestiami związanymi z odpowiedzialnością zbiorową. Wieloletnie studia nad problematyką zbrodni wojennych spowodowały, że w latach osiemdziesiątych odrębnym przedmiotem badań Profesora Jana Waszczyńskiego, wykładów prowadzonych na Uczelni, a także kolejnych publikacji stało się również międzynarodowe prawo karne. Wśród prac z tego zakresu wymienić należy zwłaszcza artykuły: Czy międzynarodowe prawo karne stanowi samodzielna dziedzine prawa ${ }^{18}$, Projekty międzynarodowego kodeksu karnego ${ }^{19}$, opracowanie: Zbrodnie przeciw ludzkości (narodziny i rozwój pojęcia) ${ }^{20}$, artykuł Das

15 System Prawa Karnego. O przestępstwach w szczególności, t. IV, cz. 1, Wrocław 1985; t. IV, cz. 2, Wrocław 1989.

16 Prawo karne materialne (w zarysie). Nauka o przestępstwie, Łódź 1973; Prawo karne w zarysie. Nauka o ustawie karnej i przestępstwie, Łódź 1975 [następne wydania: 1979, 1980, 1992]; Prawo karne w zarysie. Część szczególna, Łódź 1981; Prawo karne w zarysie. Nauka o karze i innych środkach penalnych, Łódź 1983.

17 „Biuletyn Głównej Komisji Badania Zbrodni Hitlerowskich” 1972, t. XXIV.

18 "Acta Universitatis Lodziensis” 1985, Folia Iuridica nr 22.

19 "Acta Universitatis Lodziensis” 1988, Folia Iuridica nr 35.

20 „Palestra” 1986, nr 10-11. 
Völkerrecht und das polnische Strafrech $t^{21}$. Część prac Profesora publikowana została w językach obcych: angielskim, francuskim, niemieckim, włoskim i rosyjskim.

Dzięki wysokiej pozycji naukowej i doskonałej znajomości języków obcych (angielski, niemiecki, włoski, francuski, rosyjski) Profesor utrzymywał liczne kontakty z zagranicznymi ośrodkami naukowymi, uczestniczył w konferencjach międzynarodowych, wygłaszał wykłady i referaty $\mathrm{w}$ europejskich uniwersytetach. Uczestniczył m.in. w seminariach organizowanych przez Uniwersytet im. J. Attili w Szegedzie. Prowadził wykłady w Lyonie (Lyon II), Strasburgu oraz Giessen (Justus-Liebig-Uniwersität). Brał udział w międzynarodowym seminarium zorganizowanym przez Uniwersytet w Perugii (1980), w seminariach na temat kary śmierci (Syrakuzy 1987) oraz na temat praw ofiary przestępstwa (Mediolan 1988). Na IX Kongresie Międzynarodowego Stowarzyszenia Prawa Karnego (Budapeszt 1974) był referentem krajowym jednego z czterech dyskutowanych problemów i przewodniczył obradom jednej z sekcji ${ }^{22}$.

Odrębnego podkreślenia wymagają zasługi Profesora i jego wkład do prac nad kodyfikacją prawa karnego, w którym brał aktywny udział od czasu powołania go w 1980 r. do składu Komisji ds. Reformy Prawa Karnego przy Ministrze Sprawiedliwości.

Autorytet naukowy Profesora sprawiał, że niezmiernie często powoływano go na recenzenta $\mathrm{w}$ prowadzonych na różnych uczelniach przewodach habilitacyjnych i doktorskich oraz w przewodach o nadanie tytułu profesora. Imponująca lista recenzowanych prac doktorskich i habilitacyjnych obejmuje kilkadziesiąt pozycji. Pod naukowym kierownictwem Profesora powstało 12 rozpraw doktorskich. Był opiekunem naukowym w dwóch przewodach habilitacyjnych.

Profesor był znakomitym dydaktykiem, zawsze życzliwym studentom, mimo stawiania im wysokich wymagań. Nie sposób zliczyć słuchaczy jego prowadzonych przez wiele lat z niezwykłą sumiennością i energią wykładów z prawa karnego, ustroju organów ochrony prawnej, międzynarodowego prawa karnego. Imponująca jest także liczba kilkuset prac magisterskich, których był promotorem. Kolejne roczniki studentów podejmowały starania, aby dostać się na seminarium prowadzone przez Profesora w Katedrze Prawa Karnego UŁ. Zawsze dużym zainteresowaniem cieszyło się także prowadzone przez niego seminarium doktoranckie.

21 „Archivum Iuridicum Cracoviense” 1987, nr XX.

${ }^{22}$ Na temat kontaktów zagranicznych Profesora - por. szerzej S. Lelental, Działalność..., s. 6. 
Profesor Jan Waszczyński był doskonałym kierownikiem naukowym i troskliwym opiekunem dbającym o rozwój naukowy swoich uczniów. Był wzorem nie tylko znakomitego, pracowitego i twórczego naukowca, sumiennego dydaktyka, świetnego wykładowcy i życzliwego nauczyciela, wybitnego znawcy teorii i praktyki prawniczej, ale także niezwykle prawym i uczciwym człowiekiem, otwartym i bezpośrednim, pełnym osobistego uroku i życzliwości oraz przekazywanego innym optymizmu. 





Tadeusz Szulc

\section{Bolesław Wilanowski (1885-1952)}

olesław Wilanowski urodził się 30 stycznia 1885 r. w Bolimowie w po$\mathcal{S}$ wiecie łowickim, gdzie ukończył szkołę początkową. Naukę kontynuował w II Gimnazjum w Warszawie, następnie odbył studia w Wyższym Seminarium Duchownym w Warszawie i w Akademii Duchownej w Petersburgu, które ukończył w 1911 r. W roku 1912 jako ks. Bolesław Wilanowski Magister Św. Teologii opublikował pracę pod tytułem Proroctwa Starego Testamentu a Chrystianizm. Szkic krytyczno-porównawczy o poczatkach chrześcijaństwa1. Doktorat teologii uzyskał we Wrocławiu. Zdobył wykształcenie teologiczne, filologiczne i prawnicze. Habilitował się w roku 1919 na Wydziale Teologicznym Uniwersytetu Jana Kazimierza we Lwowie, otrzymując stopień docenta. W latach 1919-1939 pracował na Uniwersytecie Stefana Batorego w Wilnie jako zastępca profesora (docent), w lipcu 1920 r. mianowany został profesorem nadzwyczajnym, od 1 października 1927 r. zatrudniony jako profesor zwyczajny na Wydziale Teologicznym. W roku akademickim 1923/1924 prowadził seminaria: Teologii Fundamentalnej oraz Pisma Świętego Nowego Testamentu². 22 października 1929 r. prezydent Ignacy Mościcki mianował ks. dr. Wilanowskiego profesorem zwyczajnym teologii dogmatycznej fundamentalnej na Wydziale Teologicznym USB w Wilnie. W tym samym roku uzyskał doktorat prawa kanonicznego ${ }^{3}$. W latach 1924/1925, 1925/1926, 1926/1927 pełnił funkcję prodziekana. Na Uniwersytecie Wileńskim prowadził wykłady z teologii fundamentalnej, z patrologii oraz z encyklopedii i metodologii nauk teologicznych.

${ }^{1}$ Proroctwa Starego Testamentu a Chrystianizm. Szkic krytyczno-porównawczy o początkach chrześcijaństwa, przedmową opatrzył ks. Czesław Sokołowski, Warszawa 1912.

${ }^{2}$ Uniwersytet Stefana Batorego w Wilnie, Skład Uniwersytetu w roku akademickim 1923/24, Druk Józefa Zawadzkiego w Wilnie, s. 18-19.

${ }^{3}$ M. Kornat, Bolszewizm Totalitaryzm Rewolucja Rosja. Początki sowietologii i studiów nad systemami totalitarnymi w Polsce (1918-1939), t. I, Kraków 2004, s. 154-155. 
W 1929 r. ks. profesor Wilanowski został, zdaniem Marka Kornata, przeniesiony do stanu świeckiego i rozpoczął pracę jako profesor na Wydziale Prawa i Nauk Społecznych ${ }^{4}$. Informacja ta nie znajduje potwierdzenia w XII i XIII Spisach Wykładów na lata akademickie 1929/1930 i 1930/1931, w których nadal figuruje jako osoba duchowna prowadząca zajęcia na Wydziale Teologicznym ${ }^{5}$. Jako osoba świecka profesor został wymieniony w składzie pracowników naukowych Wydziału Prawa i Nauk Społecznych na rok akademicki 1931/1932. Na tym Wydziale objął funkcję kierownika Zakładu Prawa Kościelnego ${ }^{6}$ prowadząc wykłady z prawa kościelnego i prawa małżeńskiego oraz seminaria z obu tych przedmiotów ${ }^{7}$. W latach 1937-1939 pełnił funkcję dziekana Wydziału Prawa i Nauk Społecznych.

W ramach działającego w Wilnie Instytutu Naukowo-Badawczego Europy Wschodniej prowadził od $1935 \mathrm{r}$. seminarium w zakresie badań stosunków kulturalnych w republikach radzieckich, przekształcone w $1937 \mathrm{r}$. w referat kultury i oświaty. W Szkole Nauk Politycznych w Wilnie prowadził wykłady ze stosunków wyznaniowych w ZSRR oraz z organizacji pracy naukowej i nauczania $\mathrm{w}$ tym $\mathrm{kraju}^{8}$. Pod kierunkiem profesora powstały m.in. trzy prace dyplomowe, napisane przez absolwentów Szkoły Nauk Politycznych, poświęcone zagadnieniom sowietologicznym ${ }^{9}$. W ży214 ciorysie złożonym na tworzonym w 1945 r. Uniwersytecie Łódzkim pominął informację o swej pracy w Szkole Nauk Politycznych.

W okresie zatrudnienia na USB ks. profesor B. Wilanowski opublikował następujące prace: List św. Polikarpa do Filipensów, studium patrolo-

${ }^{4}$ Ibidem, s. 155.

${ }^{5}$ Uniwersytet Stefana Batorego, XII Spis Wykładów na trzy trymestry w roku akademickim 1929/30, Druk Józefa Zawadzkiego w Wilnie, s. 10; XIII Spis Wykładów [...] w roku akademickim 1930/31, Druk Józefa Zawadzkiego w Wilnie, s. 10. Nie znajdujemy go w składzie pracowników Wydziału Prawa i Nauk Społecznych w ww. latach, zob. XII i XIII Spis Wykładów..., s. 12-15.

${ }^{6}$ XIV Spis Wykładów na trzy trymestry w roku akademickim 1931/32, Druk Józefa Zawadzkiego w Wilnie, s. 15; XV Spis Wykładów [...] w roku akademickim 1932/33, Druk Józefa Zawadzkiego w Wilnie, s. 15; Uniwersytet Stefana Batorego w Wilnie, Skład Uniwersytetu w roku akademickim 1934/35, Druk Józefa Zawadzkiego w Wilnie, s. 29.

7 Uniwersytet Stefana Batorego w Wilnie, XVIII Spis Wykładów na trzy trymestry w roku akademickim 1935/1936, Druk Józefa Zawadzkiego w Wilnie, s. 18-19.

${ }^{8}$ M. Jackiewicz, Instytut Naukowo-Badawczy Europy Wschodniej w Wilnie, „Magazyn Polski” [ogólnokrajowy miesięcznik Społecznego Zjednoczenia „Związek Polaków na Białorusi"], maj 2014, nr 5 (101), s. 15-16.

${ }^{9}$ Mianowicie: W. Klanowski, Struktura szkolnictwa w ZSRR (1937); I. Hołub, Polityka szkolna partii komunistycznej w zakresie szkolnictwa powszechnego (1937); L. Zybajło, Oświata pozaszkolna (polityczna) w RSFRR ze szczególnym uwzględnieniem wsi (1938); zob. M. Kornat, Instytut Naukowo-Badawczy Europy Wschodniej w Wilnie (1930-1939) i jego wkład w rozwój polskiej sowietologii, „Kwartalnik Historyczny” 2000, R. CVII, nr 3, s. 79-80. 
giczne (Wilno 1921); Działalność prawodawcza papieża Benedykta XV (1925); Prawo małżeńskie Kościoła rzymsko-katolickiego, z. 1 (Wilno 1928); Rozwój historyczny procesu kanonicznego, t. I; Proces kościelny w starożytności chrześcijańskiej (1929); Stosunek kościoła do państwa w świetle ostatnich konkordatów (1930); Zwyczaj w Kościele katolickim: Cerkiew prawosławna (sobór moskiewski z 1917 r.); Staroobrzędowcy (1934); Zwyczaj w Kościele katolickim (1941, nakładem Cerkwi prawosławnej w Wilnie). W latach 1923-1926 był redaktorem i wydawcą „Kwartalnika Teologicznego Wileńskiego”10, w latach zaś 1930-1931 - wraz z profesorem Stanisławem Fr. Zajączkowskim - redaktorem naczelnym "Ateneum Wileńskiego. Czasopisma naukowego poświęconego badaniom przeszłości ziem Wielkiego X. Litewskiego".

Lata okupacji spędził w Łodzi, Warszawie i Piotrkowie. W okresie okupacji hitlerowskiej Profesor Wilanowski stanął na czele działającej w konspiracji Komisji ds. Organizacji Szkolnictwa Wyższego w Łodzi, która działała w strukturze miejscowej agendy Delegatury Rządu RP na Kraj (Rządu Londyńskiego). Komisja ustaliła strukturę nowej uczelni, a nawet typowała łódzkie gmachy, które miały być przydzielone poszczególnym wydziałom. W 1943 r. działalność Komisji została ograniczona z uwagi na wyjazd Profesora Wilanowskiego, któremu groziło aresztowanie, do Piotrkowa Trybunalskiego, a wkrótce zawiesiła działalność. Wilanowski przeniósł się czasowo do Warszawy, a przez ostatni okres okupacji, od sierpnia 1944 do stycznia 1945 r., przebywał ponownie w Piotrkowie Trybunalskim.

W styczniu 1945 r. przybył do Łodzi, gdzie otrzymał od ówczesnego Delegata Rządu na miasto Łódź i województwo łódzkie zadanie organizacji uniwersytetu. 15 lutego tego roku został nominowany przez Ministerstwo Oświaty w Lublinie na Delegata Ministerstwa do Spraw Szkolnictwa Akademickiego. Opowiadał się za powołaniem tzw. poliuniwersytetu, składającego się z 12 wydziałów, obejmującego tradycyjne kierunki nauk uniwersyteckich, politechnicznych, lekarskich, rolniczych, ekonomicznych i artystycznych. Od początku poświęcił się przede wszystkim organizacji Wydziału Prawno-Ekonomicznego. Objął Katedrę Prawa Kościelnego, po jej zaś likwidacji w roku 1946 otrzymał powołanie na Katedrę Historii Prawa na Zachodzie Europy; prowadził wówczas wykłady z tego przedmiotu, jak również z prawa wyznaniowego. W latach 1946/1947 i 1947/1948 pełnił obowiązki dziekana Wydziału.

15 października 1947 r. Prezydent Rzeczypospolitej mianował Wilanowskiego profesorem zwyczajnym Historii Prawa na Zachodzie Europy

${ }^{10}$ Na łamach którego opublikował następujące artykuły: List Benana: sprawa pobytu Jezusa Chrystusa w Egipcie, s. 88-105; Znaczenie imienia Mirjam (= Marja), s. 113; Apologja Aristidesa, s. 424-484 („,Kwartalnik Teologiczny Wileński” 1923-1924, nr 1-2). 
na Wydziale Prawno-Ekonomicznym Uniwersytetu Łódzkiego w Łodzi. W okresie pracy na Uniwersytecie Łódzkim opublikował m.in. prace: Powszechna historia prawa i ustrojów państwowych, z. 1, Ludy koczownicze, Asyria i Babilonia, Łódź 1949; Une nouvelle interpretation du § 31 du Recueil des Lois Assyriennes, "Journal of Juristic Papyrology" 4 (1950); Niektóre zagadnienia asyryjskiego prawa małżeńskiego a prawo małżeńskie współczesnych nomadów (1951) ${ }^{11}$.

$\mathrm{Z}$ dniem 1 listopada 1950 r. przeszedł w stan spoczynku, jednakże to nie zakończyło jego działalności dydaktycznej, gdyż objął lektorat z języka rosyjskiego na Wydziale Prawa i na Wydziale Filologii jako pracownik kontraktowy.

W styczniu 1946 r. Profesor Wilanowski uczestniczył jako biegły w procesie wytoczonym przez władze komunistyczne biskupowi gdańskiemu Karolowi Marii A. Splettowi ${ }^{12}$.

Od 1938 r był członkiem Stronnictwa Ludowego. Od 1945 r. z ramienia Stronnictwa Ludowego był członkiem Wojewódzkiej Rady Narodowej w Łodzi.

W roku 1943, jak wynika ze spisanego przez niego życiorysu, był żonaty; pisał w nim, że przypadkowo uniknął aresztowania, cała zaś jego rodzina wraz żoną została wówczas aresztowana i wywieziona do Oświę216 cimia.

Profesor zw. dr habil. Bolesław Wilanowski zmarł w Łodzi dnia 4 października $1952 \mathrm{r}$.

11 Pełna bibliografia prac Profesora Bolesława Wilanowskiego: „Prawo Kanoniczne” $1979,1-2$, s. 260-263.

12 B. Wilanowski, Sprawa Spletta w świetle prawa kanonicznego, „Demokratyczny Przegląd Prawniczy" 1946, R. II, nr 3-4, s. 57-59; T. Bolduan, Biskup Carl Maria Splett - od mitów ku prawdzie, „Studia Pelplińskie” 1989, s. 79-95. 


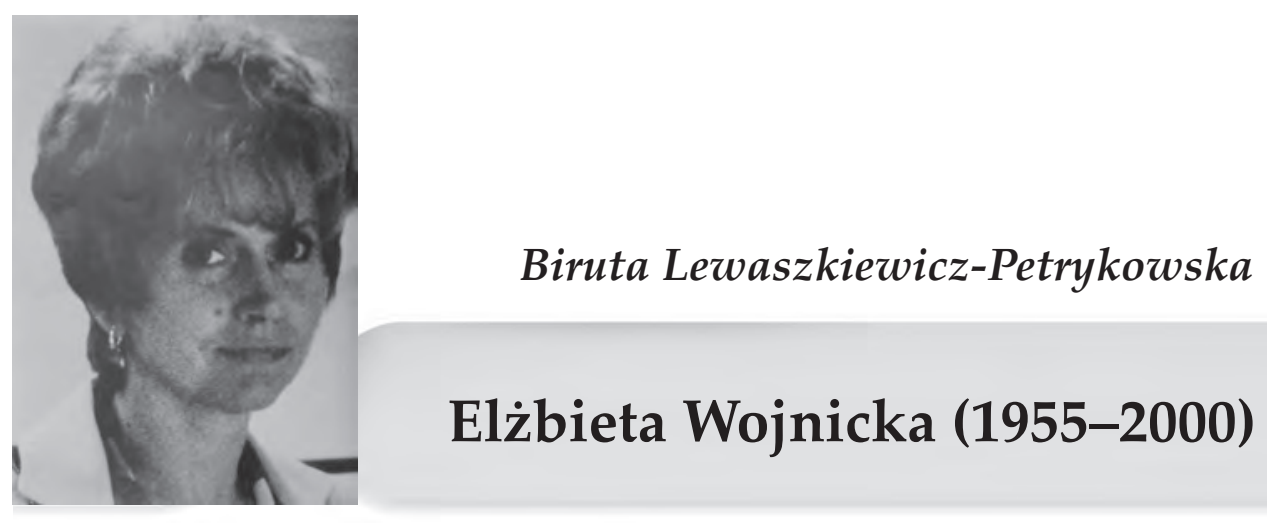

Clżbieta Wojnicka, z domu Kaczorowska, urodziła się 26 stycznia 1955 r. Ow Pabianicach. W latach 1972-1977 studiowała prawo na Wydziale Prawa i Administracji UŁ. Już w czasie studiów zwracały uwage jej nieprzeciętne zdolności, umiejętność bardzo precyzyjnego wypowiadania się i piękna polszczyzna. Studia ukończyła z wyróżnieniem i uzyskała stopień magistra w $1977 \mathrm{r}$.

Z dniem 1 października 1977 r. została zatrudniona w Katedrze Prawa Cywilnego, Wydział Prawa i Administracji UŁ, w charakterze asystenta stażysty i od tego czasu w Katedrze tej nieprzerwanie pracowała przechodząc kolejne stopnie kariery naukowej (asystent, adiunkt, doktor habilitowany).

Równolegle odbyła aplikację sądową (1977-1979) zakończoną egzaminem sędziowskim, zdanym z wynikiem bardzo dobrym (1979 r.).

W 1990 r. uzyskała stypendium rządu francuskiego, które pozwoliło jej na czteromiesięczny pobyt w Paryżu. Uczestniczyła tam w wykładach $\mathrm{z}$ prawa cywilnego oraz $\mathrm{w}$ seminariach $\mathrm{z}$ prawa autorskiego, prowadzonych przez wybitnych cywilistów (G. Viney, C. Colombet, A. Françon). Zbierała też materiały do dalszej pracy naukowej w Institut de Recherches en Propriété Intellectuelle Henri Desbois.

Doktoryzowała się w 1986 r. na podstawie rozprawy Autorskie prawa zależne (promotor prof. dr hab. B. Lewaszkiewicz-Petrykowska). Dysertacja uzyskała nagrodę III stopnia w konkursie „Państwa i Prawa” na najlepsze prace doktorskie i habilitacyjne. Zmodyfikowana wersja wymienionej rozprawy została wydana pod tym samym tytułem przez Wydawnictwo UŁ w 1990 r. W tej postaci monografia Autorskie prawa zależne została nagrodzona przez ministra edukacji narodowej nagrodą za osiągnięcia naukowo-badawcze.

Monografia Autorskie prawa zależne zawiera pogłębioną analizę twórczości zależnej i praw przysługujących autorom opracowań. Zawarte 
w niej rozważania obejmują wielkie bogactwo zagadnień. O wartości tej pracy świadczy najlepiej to, że jej zasadnicze tezy zachowały aktualność mimo zmian ustawodawczych, tzn. uchwalenia nowej ustawy o prawie autorskim i prawach pokrewnych w 1994 r. Dodać wypada, iż broniona w cytowanej monografii konstrukcja majątkowego charakteru prawa zezwalania na wykonywanie autorskich praw zależnych została przyjęta jako podstawa unormowania w obowiązującej ustawie.

Stopień naukowy doktora habilitowanego nauk prawnych w zakresie prawa cywilnego został nadany dr Elżbiecie Wojnickiej jednomyślną uchwałą Rady Wydziału Prawa i Administracji UŁ z 26 września 1997 r. Recenzentami w przewodzie habilitacyjnym byli: prof. zw. dr hab. Maria Poźniak-Niedzielska z Uniwersytetu M. Curie-Skłodowskiej w Lublinie, prof. dr hab. Ryszard Markiewicz z Uniwersytetu Jagiellońskiego oraz prof. zw. dr hab. Adam Szpunar z Uniwersytetu Łódzkiego. Podstawę habilitacji stanowiły ocena całokształtu dorobku oraz rozprawa habilitacyjna Ochrona autorskich dóbr osobistych ${ }^{1}$. Praca ta uzyskała Nagrodę I stopnia Ministra Edukacji Narodowej.

Monografia Ochrona autorskich dóbr osobistych jest po prostu znakomita. Stanowiła ona pierwsze w literaturze polskiej całościowe opracowanie tytułowego tematu. Profesor dr hab. Adam Szpunar napisał: „Ukazanie się recenzowanej rozprawy jest prawdziwym wydarzeniem w nauce polskiej” (recenzja rozprawy habilitacyjnej, s. 2). Badane zagadnienia, sytuujące się na styku różnych działów prawa cywilnego, zostały wszechstronnie omówione. W szczególności przykuwają uwagę bardzo precyzyjne rozważania dotyczące stosunku autorskich praw osobistych do dóbr osobistych powszechnego prawa cywilnego. Monografia zawiera wielkie bogactwo informacyjne, staranne przedstawienie prawa porównawczego łącznie z orzecznictwem sądowym w obcych systemach prawnych (w szczególności francuskim). Przesądza to też zresztą o wielkiej przydatności praktycznej pracy. Napisana nieskazitelnym stylem, monografia ta przedstawia nowatorską interpretację i propozycje twórczych rozwiązań. Zwraca uwagę celna wykładnia art. 16 prawa autorskiego, chodzi o sformułowanie „więź twórcy z utworem”. Autorka głosi, że więź między twórcą i dziełem jest tożsama z autorstwem. Szczególnego podkreślenia wymagają uwagi dotyczące plagiatu, prekursorskie rozważania odnoszące się do konfliktu między prawem autorskim i prawem własności, a wreszcie dogłębne zbadanie losów prawa osobistości po śmierci twórcy.

Główną domeną pracy badawczej dr hab. Elżbiety Wojnickiej było prawo na dobrach niematerialnych, zwłaszcza prawo autorskie. Większość jej publikacji dotyczy właśnie tego działu. Warte uwagi są też pu-

${ }^{1}$ Wydawnictwo UŁ, Łódź 1997. 
blikowane przez nią recenzje dzieł uczonych zagranicznych (francuskich, szwajcarskich). Na początku lat dziewięćdziesiątych zajmowała się również prawem przedsiębiorstw państwowych, a w szczególności problematyką stosowania instytucji cywilnoprawnych $\mathrm{w}$ procesach przekształceń własnościowych, a także prawem konsumenckim.

Spośród prac wykonanych po habilitacji na czoło wysuwa się monograficzne opracowanie, zawarte w Systemie Prawa Prywatnego jako rozdział piąty tomu trzynastego, pt. Autorskie prawa osobiste ${ }^{2}$. Wprawdzie ukazało się ono drukiem już po śmierci autorki, jednakże całkowicie gotowe, wykończone i skierowane do druku było jeszcze za jej życia. Doczekało się też kolejnych wydań: II w 2007 r. i III w 2013 r. Jest to dzieło fundamentalne. Stanowi ono jedyne tak pogłębione studium autorskich praw osobistych w Polsce. Rozważania na temat istoty autorstwa, ochrony dóbr osobistych zmarłego twórcy czy też konfliktu pomiędzy prawem własności a prawami twórcy, nie mają sobie równych. Nic przeto dziwnego, że dzieło to stanowi stale przedmiot zainteresowania i inspiruje do dyskusji. Powszechnie też jest cytowane.

Doktor hab. Elżbieta Wojnicka była świetnym dydaktykiem. Prowadzone przez nią zajęcia odznaczały się bardzo wysokim poziomem i atrakcyjną formą. Zawsze starannie przygotowana, dokładała maksimum wysiłku w celu jak najlepszego przekazania wiedzy studentom. A zajęć tych prowadziła wiele zarówno wykłady, jak i ćwiczenia oraz proseminarium $z$ prawa cywilnego. Oczywiście zmieniały się one $w$ różnych czasach. Należy wskazać niektóre z nich: 1) wykłady: część ogólna prawa cywilnego, prawo rzeczowe, prawo rodzinne - II rok (kierunek Prawo, studium wieczorowe); prawodawstwo opiekuńcze - V rok pedagogiki; prawo autorskie - V rok (Prawo, stacjonarne i wieczorowe); prawo autorskie - polonistyka, specjalizacja edytorstwo, a także na studiach podyplomowych prowadzonych w Instytucie Badań Europejskich UŁ; 2) ćwiczenia - właściwie ze wszystkich części prawa cywilnego, tzn. części ogólnej, prawa rzeczowego i prawa rodzinnego na II roku Prawa oraz zobowiązań i prawa spadkowego na III roku Prawa; wreszcie 3) proseminarium z prawa cywilnego na III roku Prawa. Sprawowała także opiekę naukową nad osobami studiującymi w ramach indywidualnego toku studiów.

Od 1996 r. Elżbieta Wojnicka reprezentowała Polskę w Międzynarodowej Komisji Aktów Stanu Cywilnego (Commission Internationale de l'État Civil CIEC) z siedzibą w Strasburgu. Brała niezwykle aktywny udział w pracach Komisji, których celem było opracowanie zaleceń i konwencji zmierzających do zharmonizowania ustawodawstw krajowych dotyczących aktów stanu cywilnego, rodziny i obywatelstwa. Przygotowywała

2 System prawa prywatnego, t. XIII, red. J. Barta, Warszawa 2003. 
i wygłaszała referaty (w języku francuskim) zarówno na posiedzeniach roboczych Komisji, jak i na organizowanych przez nią zgromadzeniach ogólnych. Opis zadań i osiągnięć Komisji zawarła w artykule Międzynarodowa Komisja Stanu Cywilnego. Historia, osiagnięcia oraz znaczenie jej konwencji dla prawa polskiego ${ }^{3}$.

Niezwykle skromna, pełna uroku osobistego, była bardzo koleżeńska i życzliwa ludziom. Powszechnie też była lubiana i podziwiana tak przez kolegów, jak i studentów.

Zmarła 5 lipca 2000 r. w pełni sił twórczych, przegrała jednak walkę z ciężką chorobą. Osierociła 16-letnią córkę.

Kiedy się uświadomi wielkość jej talentu i prawość charakteru, można tylko powiedzieć: wybrańcy bogów umierają młodo.

3 „Kwartalnik Prawa Prywatnego” 1998, z. 2. 




Profesor Jerzy Wróblewski był jednym z najznakomitszych polskich $\int$ humanistów, człowiekiem wielkiego talentu i niezwykłej osobowości. Urodził się w Wilnie 5 września 1926 r. Ojciec jego, Bronisław Wróblewski, był profesorem Uniwersytetu im. Stefana Batorego w Wilnie i dziekanem tamtejszego Wydziału Prawa. Uprawiał naukę prawa karnego, ale jednocześnie stworzył w Wilnie znany środek badań nad teorią prawa. Jego praca Język prawny i prawniczy (Kraków 1948) jest uważana za jedną z pierwszych prób zarysowania programu analitycznej teorii prawa w Polsce. Matka Jerzego Wróblewskiego, Krystyna, z domu Hirschberg, była malarką profesorką Politechniki Krakowskiej. Jerzy Wróblewski i jego brat Andrzej kontynuowali zainteresowania rodziców. Przedwcześnie zmarły (w 1957 r.) Andrzej Wróblewski był znanym polskim malarzem bliskim nurtowi surrealizmu, a dopiero dzisiaj jesteśmy świadkami tryumfu jego twórczości.

Jerzy Wróblewski w roku 1945 rozpoczął studia prawnicze na Uniwersytecie Jagiellońskim. Już w czasie studiów zainteresował się teorią prawa, uczestnicząc $\mathrm{w}$ seminarium wybitnego teoretyka prawa Jerzego Landego. Odbył również studia z filozofii, w czasie których uczęszczał na seminarium ucznia Husserla, fenomenologa R. Ingardena. Po uzyskaniu magisterium podjął pracę na stanowisku asystenta w katedrze swego mistrza profesora Landego. W roku 1949 uzyskał stopień doktora prawa na podstawie rozprawy pt. Ocena i norma etyczna.

W dwa lata po doktoracie przeniósł się do Łodzi, gdzie na Uniwersytecie Łódzkim objął 1 września 1951 r. Katedrę Teorii Państwa i Prawa, którą kierował do końca życia. W roku 1970 uzyskał tytuł profesora zwyczajnego, w roku 1983 został wybrany do Polskiej Akademii Nauk, nieco

${ }^{1}$ Informacje biograficzne zaczerpnięto z akt osobowych J. Wróblewskiego przechowywanych w Archiwum UŁ. 
później do Fińskiej Akademii Nauk. Był doktorem honoris causa Uniwersytetu w Turku (Finlandia) i Uniwersytetu w Edynburgu (Szkocja). Otrzymał wiele odznaczeń polskich i zagranicznych. $Z$ tych ostatnich szczególnie cenił sobie Order Palm Akademickich Republiki Francuskiej.

Jerzy Wróblewski związał się z Uniwersytetem Łódzkim już na początku swej kariery naukowej i pozostał wierny tej uczelni do końca życia. Bez przesady można rzec, że stał się jednym z filarów tego uniwersytetu. Był powoływany na stanowiska uniwersyteckie. W latach 1953-1955 oraz 1958-1962 był prodziekanem, a w latach 1955-1956, 1962-1964 dziekanem Wydziału Prawa i Administracji UŁ. Był również powołany, w latach 1965-1968, na stanowisko prorektora. W roku 1981 został wybrany rektorem Uniwersytetu Łódzkiego. Ta ostatnia funkcja przypadła na okres w Polsce szczególnie trudny - powstania niezależnej opozycji politycznej i wprowadzenia stanu wojennego. Wybrany w pierwszych po wojnie demokratycznych wyborach uniwersyteckich, swoim autorytetem naukowym zdołał w znacznym stopniu złagodzić represje, które spadły na Uczelnię ze strony totalitarnego reżimu.

Organizował również życie naukowe w Polsce jako redaktor kilku czasopism naukowych. Był członkiem editorial boards większości międzynarodowych czasopism z zakresu teorii i filozofii prawa. Brał udział w międzynarodowym życiu naukowym, często przebywając za granicą jako visiting professor, uczestnik konferencji i kongresów międzynarodowych. Jego nazwisko można znaleźć na listach prestiżowych międzynarodowych towarzystw naukowych. Bez przesady można powiedzieć, że wykładów profesora Wróblewskiego słuchano na wszystkich kontynentach.

Jak już wspomniano, osoba, która wywarła wielki wpływ na poglądy naukowe Jerzego Wróblewskiego, był profesor J. Lande. Drugim źródłem inspiracji teoretycznej J. Wróblewskiego była szkoła lwowsko-warszawska, a przede wszystkim jeden jej przedstawiciel - Kazimierz Ajdukiewicz. Wpływ ten najpełniej ujawnił się w pracy Zagadnienia teorii wykładni prawa ludowego (Warszawa 1959). Posługiwał się w niej zaczerpniętą od K. Ajdukiewicza dyrektywalną koncepcjąjęzyka. Opierając się na niej argumentował, że choć dyrektywy sensu właściwe dla zdań nie odnoszą się do norm, to jednak normy są niewątpliwie sensowne. Mają zatem własne dyrektywy sensu, które nazwał dyrektywami normatywnymi. Korzystanie z tych dyrektyw jest niezbędne przy ustalaniu znaczenia nazw występujących w normach.

Również ze szkoły lwowsko-warszawskiej wywodzi się analityczne podejście do prawa, które stało się dominującą cechą teorii prawa J. Wróblewskiego. Podobnie jak K. Ajdukiewicz, J. Wróblewski odrzucał psychologiczny sposób pojmowania znaczenia na rzecz postawy językowej, choć jednocześnie opowiadał się za mentalistyczną, a nie behawioralną, wersją podejścia językowego. 
Wreszcie z polskiej tradycji uprawiania analizy językowej wywodzi się minimalizm filozoficzny w badaniach nad teorią prawa. Profesor traktował filozofię jako źródło odpowiedzi na konkretne problemy, a nie jako globalną doktrynę. W możliwość stworzenia całościowych systemów filozoficznych wątpił, z czego między innymi wynika pogląd o wielopłaszczyznowym charakterze refleksji teoretycznoprawnej. Od metody filozoficznej domagał się jasności językowej oraz intersubiektywnej sprawdzalności i komunikowalności. Pod koniec życia rygoryzm ten nieco złagodził. Zaczął dostrzegać potrzebę filozofii prawa głównie przez refleksję nad aksjologią.

Problemami aksjologicznymi interesował się zresztą przez całe życie. Zawsze opowiadał się za postawą antykognitywistyczna, nie wierzył w wartość poznawczą wypowiedzi oceniających, przynajmniej jeśli chodzi o oceny zasadnicze. Antykognitywizm zdecydował również o niechęci J. Wróblewskiego do doktryn prawa natury, co do których formułował głównie zarzuty metodologiczne. Uważał się za relatywistę $\mathrm{w}$ dziedzinie aksjologii, choć traktował relatywizm raczej jako zalecenie metodologiczne. W postawie analitycznej wobec prawa ważną rolę odgrywał dla niego umiarkowany konstruktywizm, który określał jako negację zarówno deskrypcjonizmu, jak i skrajnego konstruktywizmu.

Minimalizm filozoficzny, antykognitywizm, relatywizm i umiarkowany konstruktywizm stanowiły podstawy analitycznej teorii prawa uprawianej przez J. Wróblewskiego. Traktował je przy tym jako warunki konieczne do naukowej refleksji nad prawem. Szukając w filozofii rozwiązania konkretnych problemów teoretyczno-prawnych nigdy nie określił globalnie swych poglądów filozoficznych. Był jednak najbardziej związany z pozytywistycznym podejściem do nauki.

Mówiąc o szczegółowych problemach podejmowanych przez J. Wróblewskiego należy zaznaczyć konsekwentność w budowaniu paradygmatu teorii prawa. Przez kilkadziesiąt lat budował teorię prawa, której zręby zarysował już w swej pierwszej pracy na temat wykładni prawa. Paradygmat ten obejmuje kilka działów: teorię normy prawnej, teorię wykładni prawa, teorię systemu prawa, teorię stosowania prawa, teorię tworzenia prawa, metodologię nauk prawnych. Te sześć elementów tworzy uprawianą przez J. Wróblewskiego teorię prawa. Niezależnie od tej refleksji uprawiał również teorię państwa, a przede wszystkim badał organizację aparatu państwowego. Ważne miejsce odgrywa w dorobku naukowym J. Wróblewskiego informatyka prawnicza.

Jako wielki erudyta zajmował się również, choć głównie w latach pięćdziesiątych i sześćdziesiątych, refleksją nad historią doktryn politycznych i prawnych, której przez wiele lat był też wykładowcą. Główny nurt zainteresowań Profesora zamykał się jednak w owych sześciu działach teorii 
prawa, które traktował jako swoisty paradygmat tej dziedziny. Postaram się teraz omówić w dużym skrócie główne tezy formułowane przez Jerzego Wróblewskiego w tych wyróżnianych przez niego działach teorii prawa.

Na temat teorii normy prawnej wypowiadał się w wielu artykułach, nigdy nie napisał na ten temat osobnej monografii. Język prawny traktował jako fragment języka naturalnego. Uważał, że daje się on wyodrębnić na poziomie aktów mowy. Początkowo normę prawną wyodrębnił poprzez kryteria semantyczne, zakładając, że sensem wypowiedzi normatywnej jest wzór powinnego zachowania się, którego nie traktował nigdy jako kategorii ontologicznej. Uważał wówczas, że daje się on wyodrębnić czysto analitycznie jako zbiór dyrektyw sensowności wypowiedzi normatywnych. Konsekwentny antykognitywizm, który reprezentował w swych pracach, spowodował jednak, że już w latach siedemdziesiątych przestał przywiązywać wagę do koncepcji wzoru zachowania się jako sensu wypowiedzi normatywnych. Zaczął podkreślać pragmatyczny charakter norm jako aktów mowy i wyodrębniać je poprzez analizę funkcji mowy. Na tym tle rozróżnił pojęcie tekstu prawnego i norm prawnych jako aktów mowy formułowanych na podstawie tego tekstu, ale w określonym kontekście sytuacyjnym i kulturowym. Odrzucał zatem tezę o możliwości wskazania uniwersalnego wzoru rekonstruowania norm z tekstów prawnych. Tą drogą polemizował z tezą marksistów o niezbędności sankcji w strukturze normy prawnej.

Antykognitywizm i pragmatyczne ujęcie normy doprowadziło go do zanegowania logicznej wartości norm. Zdaniem Profesora Wróblewskiego normy są wypowiedziami sensownymi, lecz nie można o nich powiedzieć, że są prawdziwe lub fałszywe. Normy nie mogą być elementami rozumowań logicznych.

Wątpił jednak zarazem w możliwość zbudowania uniwersalnej logiki deontycznej. Rachunki deontyczne mogą mieć tylko ograniczony zasięg, obejmując tylko niektóre fragmenty języka prawnego. Istoty wnioskowań logicznych szukał zatem w kategorii racjonalności, w której kryterium prawdy i fałszu jest tylko jednym $z$ wielu kryteriów oceniania poprawności rozumowania prawniczego. Zgadzał się z tezą Roberta Alexy, że racjonalność prawnicza jest nadbudowana nad racjonalnością praktyczną.

Racjonalność wiązał z uzasadnialnością decyzji. Wykazywał istnienie wielu typów racjonalności, które mają wpływ na praktyczne myślenie prawnicze. W swoich badaniach koncentrował się jednak głównie na racjonalności uzasadnień decyzji stosowania prawa, choć uważał, że można mówić również o racjonalnie uzasadnionych ocenach i normach. Pisząc o racjonalnie uzasadnionych decyzjach podkreślał konieczność rozgraniczenia racjonalności w aspekcie wewnętrznym i zewnętrznym oraz wskazywał na istnienie wielu poziomów uzasadniania decyzji. 
Teorii wykładni poświęcił jedną ze swoich pierwszych monografii. W polskiej teorii prawa wykształciły się dwie podstawowe koncepcje teorii wykładni: semantyczna i derywacyjna. W ujęciu semantycznym wykładnia to czynność ustalania znaczenia tekstu prawnego. To ujęcie może występować $\mathrm{w}$ dwóch wersjach. W wersji intensjonalnej wykładnia to wskazanie znaczenia tekstu prawnego rozumianego jako wzór zachowania. W wersji ekstensjonalnej wykładnia to przyporządkowanie tekstowi prawnemu modelu semantycznego. W ujęciu derywacyjnym wykładnia to operacja przekładu tekstu prawnego na zespół norm prawnych, przy czym norma prawna pojęta jest jako wypowiedź jednoznaczna. Jerzy Wróblewski opowiadał się zawsze za semantycznym i intensjonalnym ujęciem wykładni prawa. Model teoretyczny wykładni oparł na maksymie rzymskiej: interpretatio cessat in claris. Uważał, że interpretacja prawnicza jest związana z kontekstem, w którym występuje stosowana norma prawna. Racjonalność prawodawcy zapewnia zrozumiałość normy opartej na dyrektywach znaczeniowych języka naturalnego. Interpretacja prawnicza pojawia się wówczas, gdy to naturalne znaczenie okazuje się niewystarczające dla rozwiązania problemu prawnego. Wątpliwość powstaje zatem ze względu na kontekst, w którym norma występuje. Profesor wyróżniał trzy typy tych kontekstów: językowy, systemowy i funkcjonalny. Z każdym $z$ nich wiązał inne rodzaje specyficznych prawniczych dyrektyw interpretacji. Decyzja interpretacyjna jest zatem zrelatywizowana do akceptowanych przez interpretatora zbiorów dyrektyw interpretacyjnych. Uważał, że o wyborze zbioru dyrektyw przez interpretatora decyduje akceptowany przez niego system wartości, a zatem, że ostatecznie wybór dyrektyw nie daje się naukowo uzasadnić.

W teorii systemów prawa polemizował z Hansem Kelsenem. Był zresztą wielkim znawcą jego czystej teorii prawa. Odrzucał transcendentalne uzasadnienie obowiązywania prawa. Negował również tezę Kelsena o dynamicznym charakterze powiązań w hierarchii systemu prawa, wskazując na mieszany - statyczno-dynamiczny charakter hierarchii systemu prawa. Zajmował się także zagadnieniami niesprzeczności i zupełności systemu prawa.

Przez ostatnie dwadzieścia lat życia zajmował się przede wszystkim problemem stosowania i tworzenia prawa. Poświęcił tym zagadnieniom aż dwie monografie. Stosowanie prawa pojmował jako proces osiąania przez organ państwa normy indywidualnej. Starannie separował różne aspekty badania tego procesu. Zarysował kilka modeli stosowania prawa: informatyczny, funkcjonalny i decyzyjny. Ten ostatni uważał za najbardziej przydatny dla nauki prawa. Na tle tego modelu analizował zagadnienie prawdy sądowej i wspomniany już problem racjonalności decyzji sądowego stosowania prawa. Pisząc o problemie prawdy sądowej 
szczególną wagę przywiązywał do podziału faktów dowodzonych przed sądem. Wskazywał, że wewnętrzne zróżnicowanie faktów uniemożliwia zbudowanie koherentnej koncepcji prawdy sądowej. W swej teorii stosowania prawa polemizował przede wszystkim z pozytywizmem prawniczym, wskazując na rolę ocen i wartości w stosowaniu prawa. Zbiory tych ocen nazywał ideologią stosowania prawa. Wskazywał na zróżnicowanie tych ideologii w historii kultury europejskiej.

Tworzenie prawa było przedmiotem jego ostatniej monografii w języku polskim. Interesowała go głównie teoria racjonalnego tworzenia prawa, użyteczna w polityce prawa. Model racjonalnego tworzenia prawa oparł na racjonalności instrumentalnej określonej przez relację środek - cel. Na tle tego modelu wiele uwagi poświęcał optymalizacji systemu prawa. Również na gruncie tworzenia prawa zajmował się problemami informatyki prawniczej.

W swej metodologii nauk prawnych rozróżniał pomiędzy jednoi wielopłaszczyznowymi ujęciami teorii prawa. Jednopłaszczyznowe teorie prawa ujmują prawo jako normę, fakt psychiki ludzkiej albo jako fakt społeczny. Prawo jest poznawane w zależności od akceptowanej na danej płaszczyźnie epistemologii oraz używanych metod badawczych. Wielopłaszczyznowe teorie prawa traktują prawo jako złożony ontologicznie przedmiot, do badania którego właściwe są metody, techniki, siatka pojęciowa różnych typów nauk. Jerzy Wróblewski opowiadał się za budową wielopłaszczyznowej teorii prawa i taki model teorii prawa starał się zawsze uprawiać. Było to prawdopodobnie źródłem jego otwartości na nowe metody badawcze oraz wielkiej erudycji naukowej. Zajmował go również problem naukowości nauk prawnych. Granice naukowości ujmował w stosunku do wartości. Odrzucał w nauce rozważanie wartości niezrelatywizowanych, dopuszczał zaś wartości zrelatywizowane. Refleksję nad wartościami niezrelatywizowanymi pozostawiał filozofii prawa.

Tak przedstawia się $\mathrm{w}$ największym skrócie teoria prawa Jerzego Wróblewskiego. W odniesieniu do tego dzieła bardzo łatwo jest, szczególnie w przypadku uczniów Profesora, dojrzeć związek głoszonych przez niego tez ze swoistym klimatem jego osobowości. Wielka skromność, tolerancja dla cudzych poglądów i rozumność powodowały, że tak niechętny był głoszeniu twierdzeń o ambicjach do powszechnej i koniecznej ważności. Starał się zawsze dostrzegać wszelkie możliwe sposoby patrzenia na badany problem. Wrażliwość wielkiego humanisty chroniła go przed uproszczonymi sądami i uleganiem naukowym modom. W swych poglądach był zawsze soba, nie ulegając emocjom i irracjonalnym motywom przy budowie teorii naukowych. Dla wszystkich, którzy go znali i nawet nie zgadzali się z jego poglądami, stanowił zawsze wzorzec wielkiego uczonego i humanisty. 


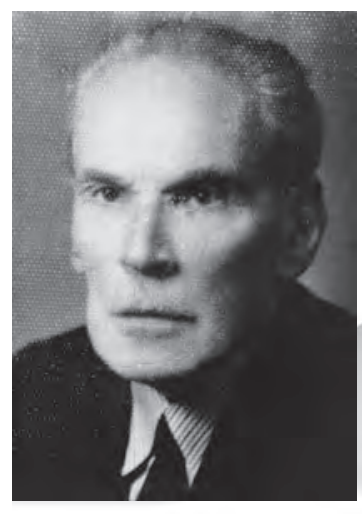

\section{Krzysztof Skotnicki}

\section{Władysław Wróblewski (1875-1951)}

$\mathcal{L}$ jedzie związani z Uniwersytetem Łódzkim mogą być dumni, że o Państwie i Prawa Państwowego na ówczesnym Wydziale Prawno-Ekonomicznym był Profesor dr hab. Władysław Wróblewski. Była to bowiem postać wybitna, bez wątpienia należąca $\mathrm{w}$ okresie międzywojennym do elity, przede wszystkim politycznej, ale i naukowej, która w nowej rzeczywistości ustrojowej związała swój los z Łodzią i utworzoną 24 maja 1945 r. nową polską Uczelnią.

Władysław Wróblewski urodził się w Krakowie 21 marca 1875 r. Jego ojcem był Wincenty Wróblewski, oficer walczący w powstaniu styczniowym, matką zaś Teodozja, z domu Bossowska. Jego starszym bratem był Stanisław Wróblewski (1868-1938), profesor Uniwersytetu Jagiellońskiego, wybitny polski prawnik romanista i jeden z najznakomitszych cywilistów, autor podręcznika do prawa rzymskiego oraz komentarzy do ustawy o spółdzielniach oraz ustawy o prawie wekslowym i czekowym, który pełnił również funkcje sekretarza generalnego (1922-1926), wiceprezesa (1926-1934), a następnie prezesa Polskiej Akademii Umiejętności, a także prezesa Najwyższej Izby Kontroli (1926-1930) oraz od roku 1935 aż do śmierci senatora powołanego przez Prezydenta RP ${ }^{1}$.

Dzieciństwo Władysław Wróblewski spędził w Krakowie. Po ukończeniu gimnazjum podjął w Uniwersytecie Jagiellońskim studia prawnicze, które zakończył w 1897 r. obroną pracy doktorskiej. Następnie zatrudnił się w austriackiej administracji państwowej w Namiestnictwie Galicyjskim. Praca w latach 1902-1911 w Prezydium Namiestnictwa sprawiła, że konieczne stało się przeprowadzenie do Lwowa. Tam też w $1911 \mathrm{r}$. zawarł ślub z pianistką Zofią Obtułowicz, absolwentką Konserwatorium we Lwowie. Małżonkowie mieli trójkę dzieci: Ferdynanda, Marię i Adama.

${ }^{1}$ Zob. Czy wiesz kto to jest?, red. S. Łoza, Warszawa 1938, s. 821-822. 
Praca $\mathrm{w}$ administracji państwowej nie przeszkodziła Władysławowi Wróblewskiemu $\mathrm{w}$ rozwijaniu zainteresowań nauką prawa, wręcz przeciwnie, pozwoliła mu na wykorzystanie nabytej wiedzy praktycznej w prowadzeniu badań. Naturalne niejako stało się też w związku z tym jego zainteresowanie prawem administracyjnym. Obrona jego rozprawy habilitacyjnej, pt. Roszczenia jednostki wobec administracji państwa ze szczególnym uwzględnieniem prawa wodnego i kwestii prawomocności administracyjnej, której recenzentami byli trzej wybitni polscy prawnicy: prof. Władysław Jaworski, prof. Michał Roztworowski i prof. Jerzy Michalski odbyła się 19 grudnia 1908 r. na Wydziale Prawa Uniwersytetu Jagiellońskiego. W czasie kolokwium Władysław Wróblewski wygłosił też wykład poświęcony prawu polowania. Po zatwierdzeniu habilitacji przez ministerstwo w Wiedniu, Władysław Wróblewski został docentem nauki administracji i prawa administracyjnego, po czym rozpoczął pracę w Uniwersytecie Jagiellońskim².

Koniec wojny światowej oraz pierwsze lata niepodległości to okres, w którym Władysław Wróblewski poświęcił swoją aktywność naukową na rzecz budowania polskiej państwowości, w tym kształtowania jej ustroju. Sprawiło to, że w roku 1917 odrzucił propozycję zostania profesorem nadzwyczajnym na Wydziale Prawa Uniwersytetu Jagiellońskiego i przeniósł się do Warszawy, gdyż Rada Regencyjna powołała go na podsekretarza stanu w Prezydium Rady Ministrów. W dniach od 3 do 14 listopada 1918 r. był nawet pełniącym obowiązki premiera Królestwa Polskiego (Regencyjnego). Od roku 1919 związany był z polską dyplomacja, początkowo jako podsekretarz stanu w Ministerstwie Spraw Zagranicznych. Z uwagi na to, że ówczesny premier i minister spraw zagranicznych, Ignacy Jan Paderewski, przebywał prawie stale za granica, przewodnicząc delegacji polskiej w Paryżu podczas rozmów pokojowych, Władysławowi Wróblewskiemu przypadło przewodniczenie stronie polskiej podczas rozmów w Berlinie i zadanie przejmowania ziem byłego zaboru pruskiego, jak i współprzewodniczenie w 1920 r. polskiej delegacji w Mińsku podczas rozmów kończących wojnę polsko-bolszewicką.

Władysław Wróblewski bardzo aktywnie uczestniczył również w pracach nad polską konstytucją. Jemu przypisuje się opracowanie w 1919 r. w Biurze Konstytucyjnym Prezydium Rady Ministrów projektu konstytucji wzorowanego na systemie rządów III Republiki Francuskiej i na tamtejszej praktyce ustrojowej, który był pierwowzorem późniejszej Konstytucji z 1921 r. $^{3}$

${ }^{2}$ Archiwum Uniwersytetu Łódzkiego, akta osobowe Władysława Wróblewskiego (życiorys).

${ }^{3}$ Zob. S. Krukowski, Geneza Konstytucji z 17 marca 1921 r., Warszawa 1977, s. 16-17; idem, Nieznany projekt konstytucji polskiej z roku 1919, "Czasopismo Prawno-Historyczne” 1975, z. 2, s. 260-261; idem, Konstytucja Rzeczypospolitej Polskiej z 1921 r., [w:] Konstytucje Polski. Studia z dziejów polskiego konstytucjonalizmu, t. II, pod red. M. Kallasa, Warszawa 1990, s. 28; A. Ajnenkiel, Polskie konstytucje, Warszawa 1983, s. 236. 
W następnych latach Władysław Wróblewski był ambasadorem Rzeczypospolitej Polskiej w Londynie (1921-1923) i Waszyngtonie (1923-1926). Po zamachu majowym w 1926 r. na krótko został odsunięty od spraw publicznych i zajmował się dziennikarstwem, będąc m.in. redaktorem naczelnym „Gazety Poznańskiej i Pomorskiej”. Już jednak w 1929 r. został Prezesem Banku Polskiego, którą to funkcję pełnił do $1936 \mathrm{r}^{4}{ }^{4}$ Jego podpis figuruje m.in. na wydawanych $\mathrm{w}$ tamtych latach banknotach.

W 1937 r. Władysław Wróblewski przeszedł na emeryturę, a podjęcie pracy w Szkole Nauk Politycznych w Warszawie spowodowało jego powrót do nauki i dydaktyki. Zostało to przerwane przez wybuch drugiej wojny światowej. Lata okupacji rodzina państwa Wróblewskich spędziła w Warszawie utrzymując się ze sprzedaży rzeczy i udzielanej przez małżonkę Profesora nauki gry na fortepianie. Najmłodszy syn trafił do Oświęcimia i zginął. Już na początku Powstania Warszawskiego, w dniu 8 sierpnia 1944 r., zostali wyrzuceni przez Niemców z płonącego domu i wypędzeni do obozu przejściowego w Pruszkowie, tracąc wszystkie rzeczy i dokumenty. $Z$ obozu w Pruszkowie udało im się jednak zbiec ${ }^{5}$.

Po wojnie Profesor Władysław Wróblewski zamieszkał z małżonką w Łodzi i był jednym z twórców powstającego Uniwersytetu Łódzkiego. Napisał wówczas skrypt Nauka o państwie i prawo państwowe oraz wykładał przedmiot poświęcony ustrojom państw współczesnych ${ }^{6}$. Profesor Tadeusz Szymczak wspominał, że Profesor Władysław Wróblewski był bardzo życzliwie nastawiony do studentów i tylko wyjątkowo stawiał ocenę niedostateczną; otrzymał ją np. student, który uparcie twierdził, że Wielka Brytania jest republiką. Profesor uczestniczył również w pracach Łódzkiego Towarzystwa Naukowego zasiadając w Komisji Statutowej oraz był członkiem Komisji Prawniczej Polskiej Akademii Umiejętności.

Spuścizna naukowa Profesora Władysława Wróblewskiego jest trudna do ustalenia, gdyż większość jego prac powstała na przełomie wieków XIX i XX i w znacznej części nie zachowała się do dzisiejszych czasów. Uważa się jednak, że była znacząca ${ }^{7}$.

Niestety nie ma też zbyt wielu dotyczących Profesora dokumentów, np. nie zachowały się żadne materiały z czasu, kiedy w okresie międzywojennym stał na czele Banku Polskiego, gdyż spłonęły one w czasie Powstania Warszawskiego. Najwięcej można się o nim dowiedzieć z życiorysu,

${ }^{4}$ Czy wiesz..., s. 822.

${ }^{5}$ Archiwum Uniwersytetu Łódzkiego, akta osobowe...

${ }^{6}$ Zob. B. Baranowski, K. Baranowski, Pierwsze lata Uniwersytetu Łódzkiego (1945-1949), Łódź 1985, s. 105.

7 Ibidem. 
który napisał, kiedy był przyjmowany do pracy w Uniwersytecie Łódzkim. Nowa rzeczywistość ustrojowa sprawiła jednak, że wyraźnie widoczna jest tam dokonana przez niego istotna selekcja faktów z jego życia.

Profesor Władysław Wróblewski zmarł 19 sierpnia 1951 r. Jest pochowany w Łodzi na Cmentarzu katolickim pw. św. Józefa (Stary Cmentarz) przy ul. Ogrodowej 39. W roku 2012 jego grób został odnowiony ze środków Narodowego Banku Polskiego, który zadeklarował również opiekę nad nim w przyszłości. 


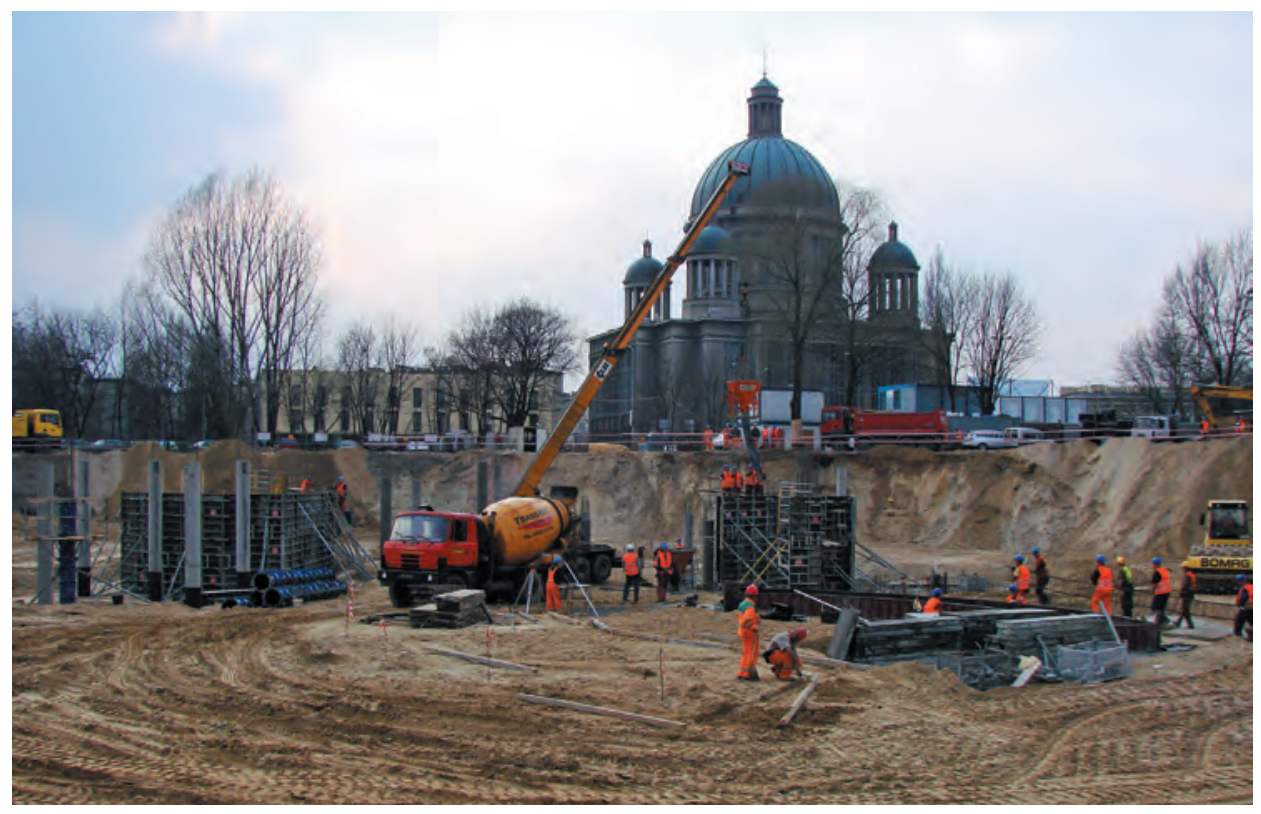

Plac budowy. Fot. Marek Górski

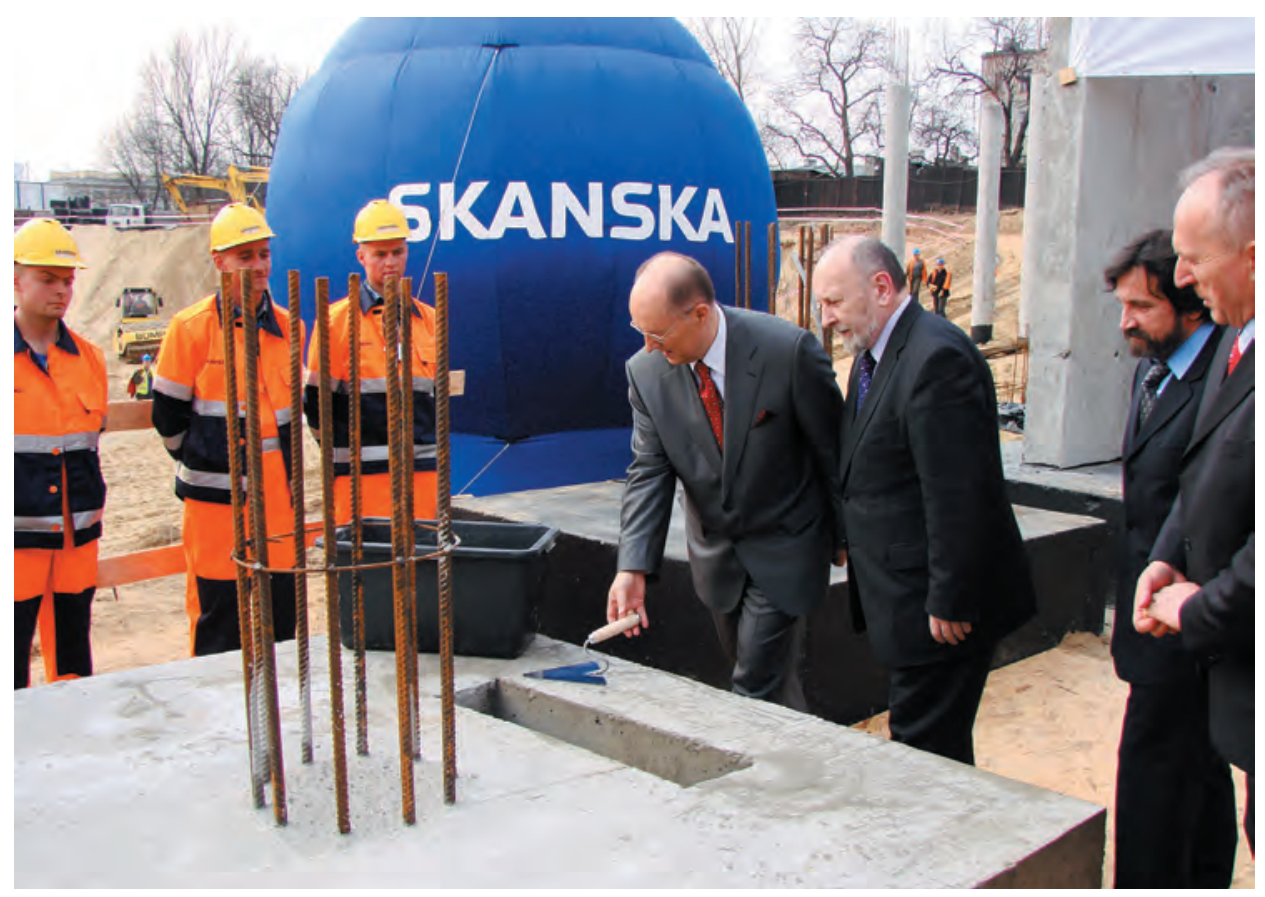

Wmurowanie kamienia węgielnego. Profesor Michał Seweryński (minister nauki i szkolnictwa wyższego), prof. Wiesław Puś (rektor UŁ), prof. Zbigniew Góral (dziekan WPiA), kanclerz Jan Rydz. Fot. Marek Górski 


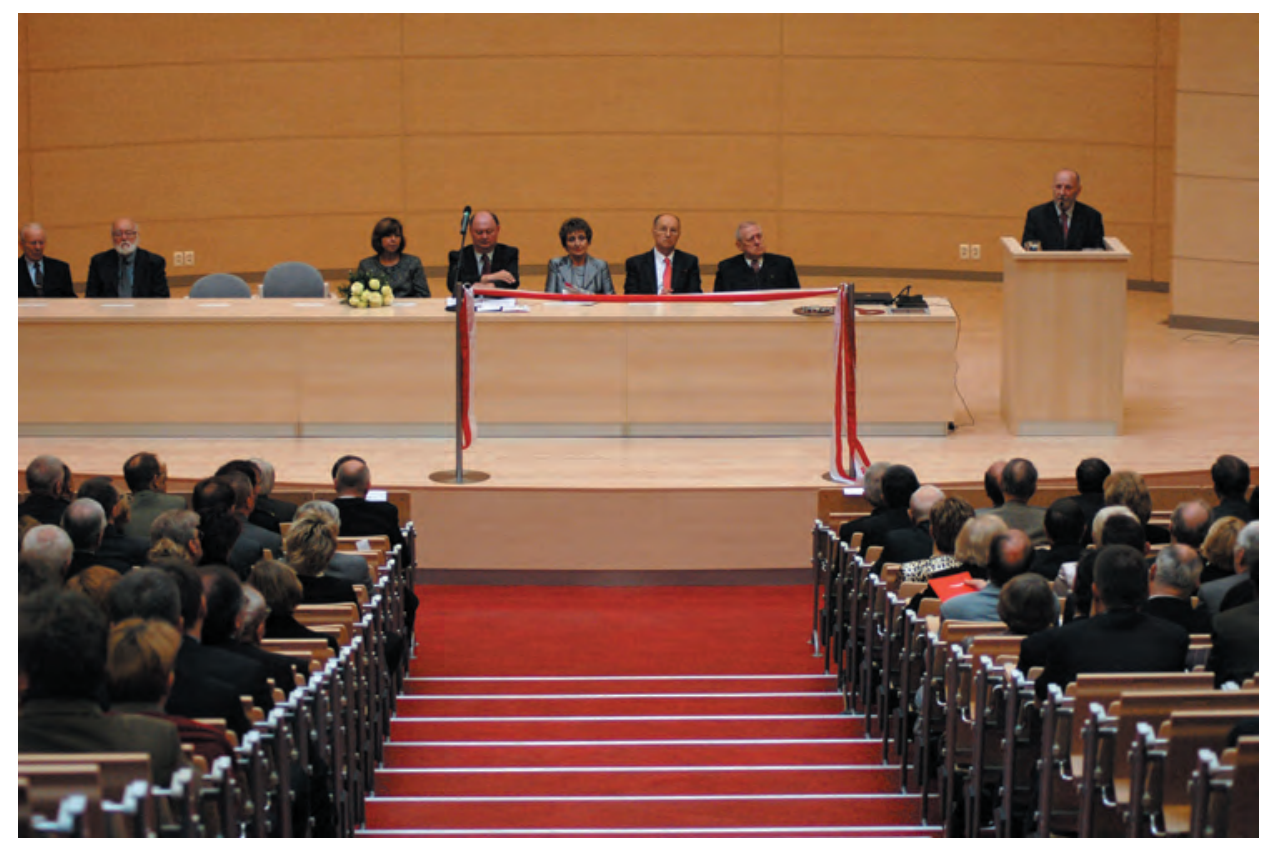

Uroczyste otwarcie budynku WPiA. Fot. Piotr Topolski

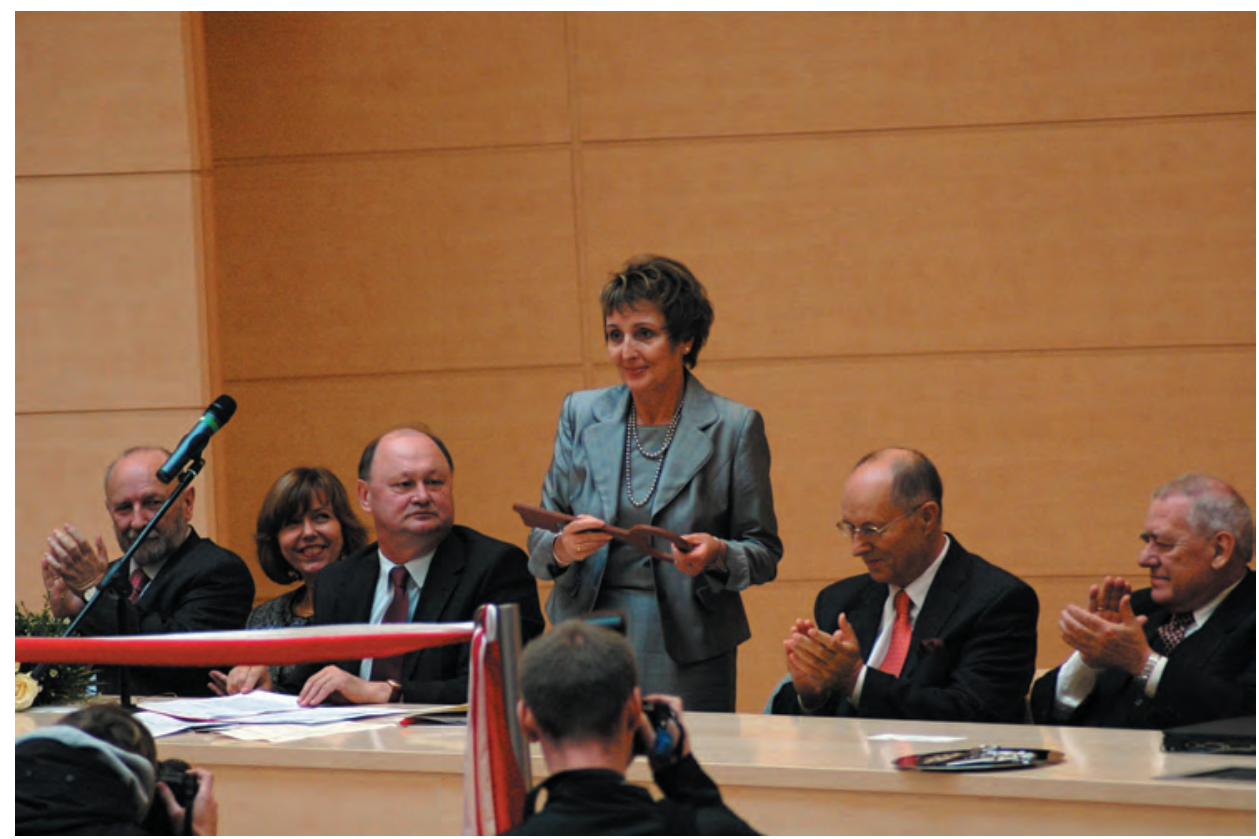

Dziekan WPiA prof. Małgorzata Pyziak-Szafnicka na otwarciu budynku WPiA Fot. Piotr Topolski 


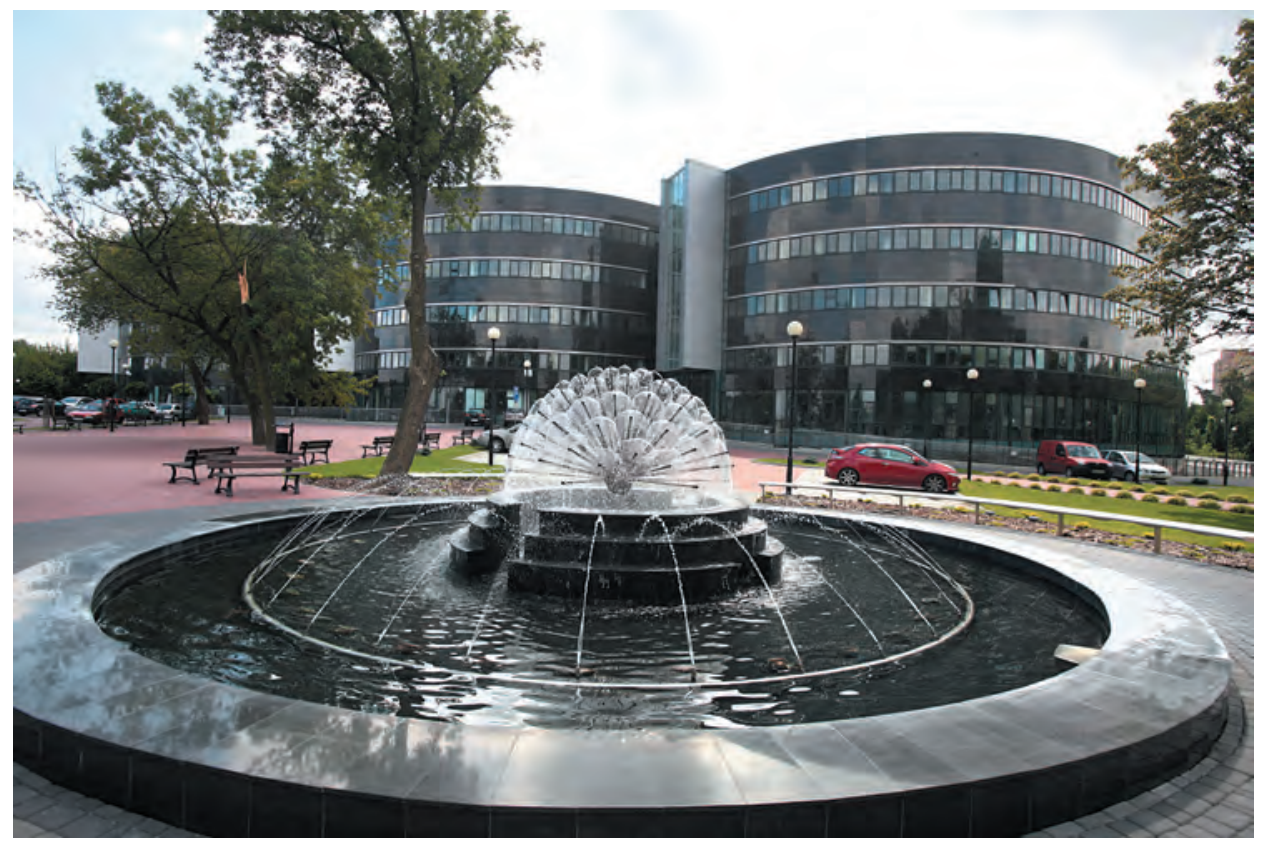

Budynek WPiA przy ul. Kopcińskiego 8/12. Archiwum WPiA

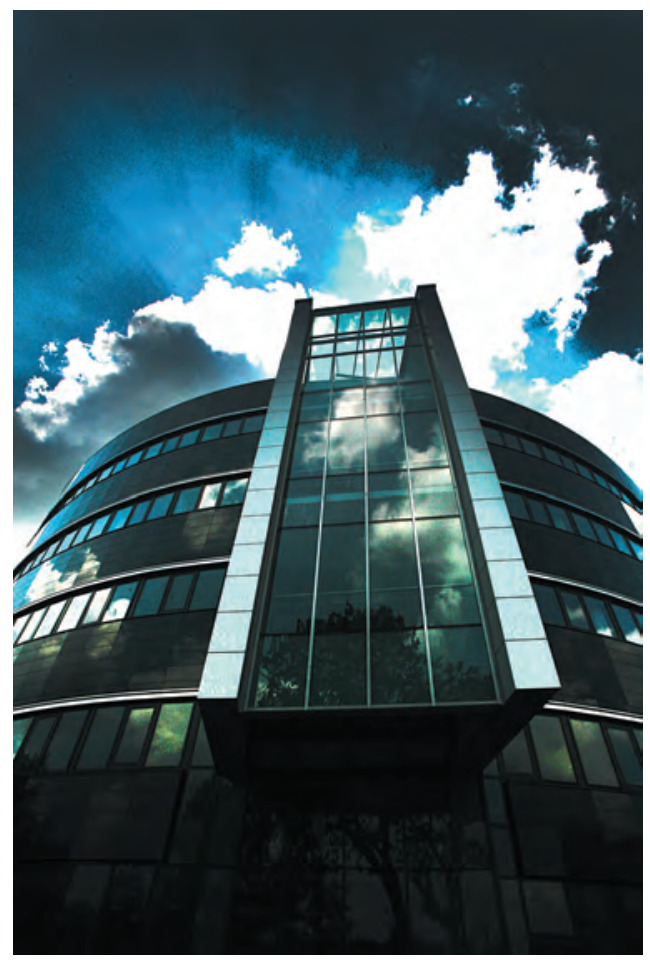

Budynek WPiA przy ul. Kopcińskiego 8/12 Archiwum WPiA 


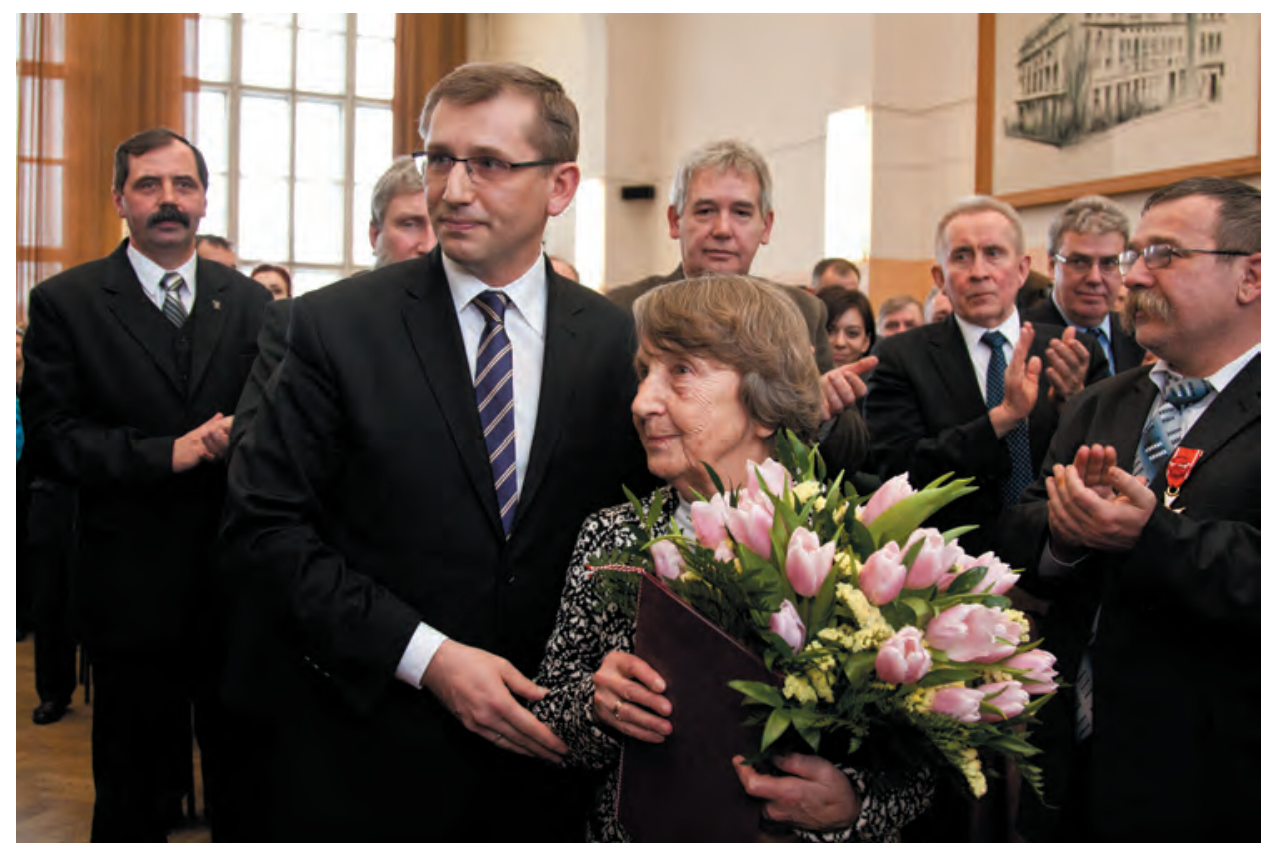

Obchody 30. rocznicy strajków studenckich. Profesor Biruta Lewaszkiewicz-Petrykowska w towarzystwie ówczesnego ministra sprawiedliwości Krzysztofa Kwiatkowskiego Centrum Promocji UŁ

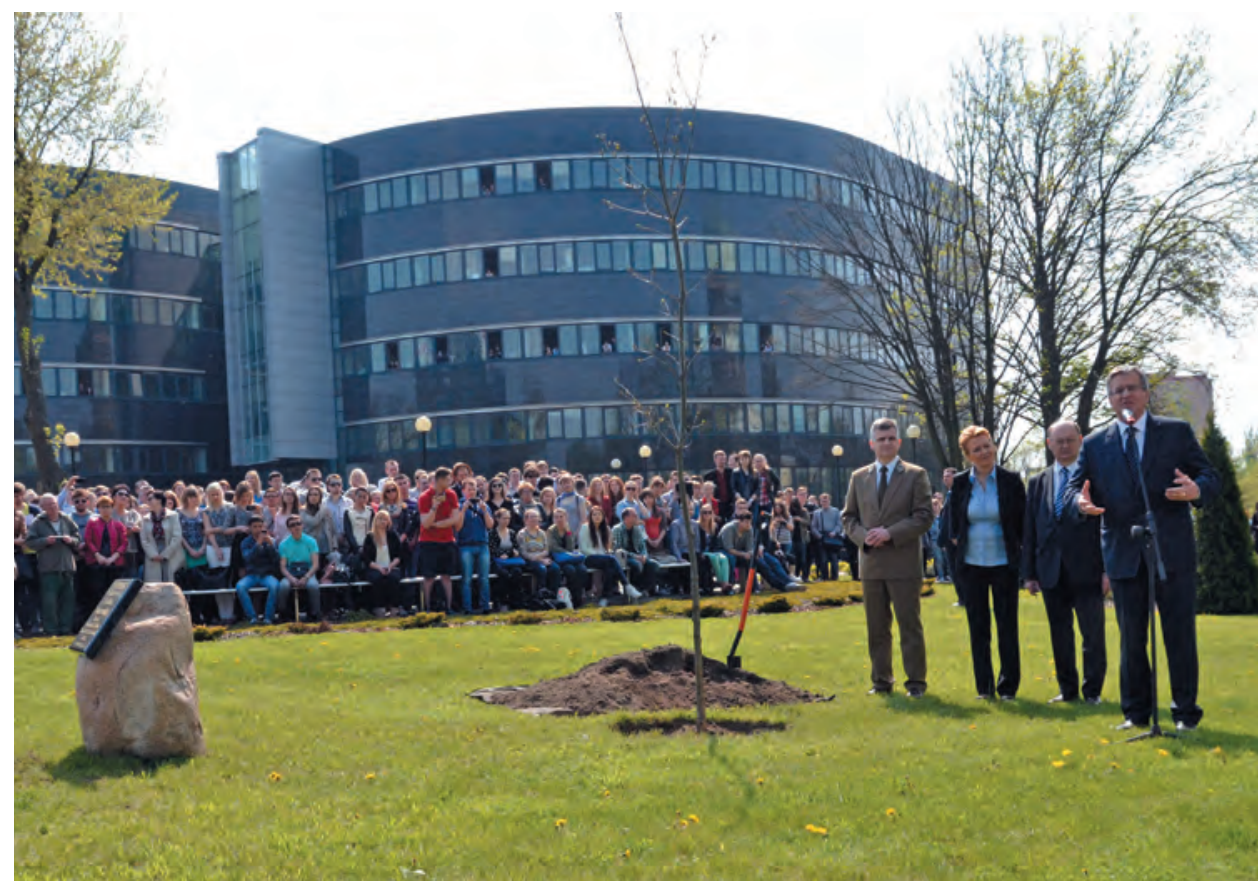

Prezydent Rzeczypospolitej Polskiej Bronisław Komorowski sadzi Dąb Wolności przed budynkiem WPiA. Fot. Anna Rolczak 


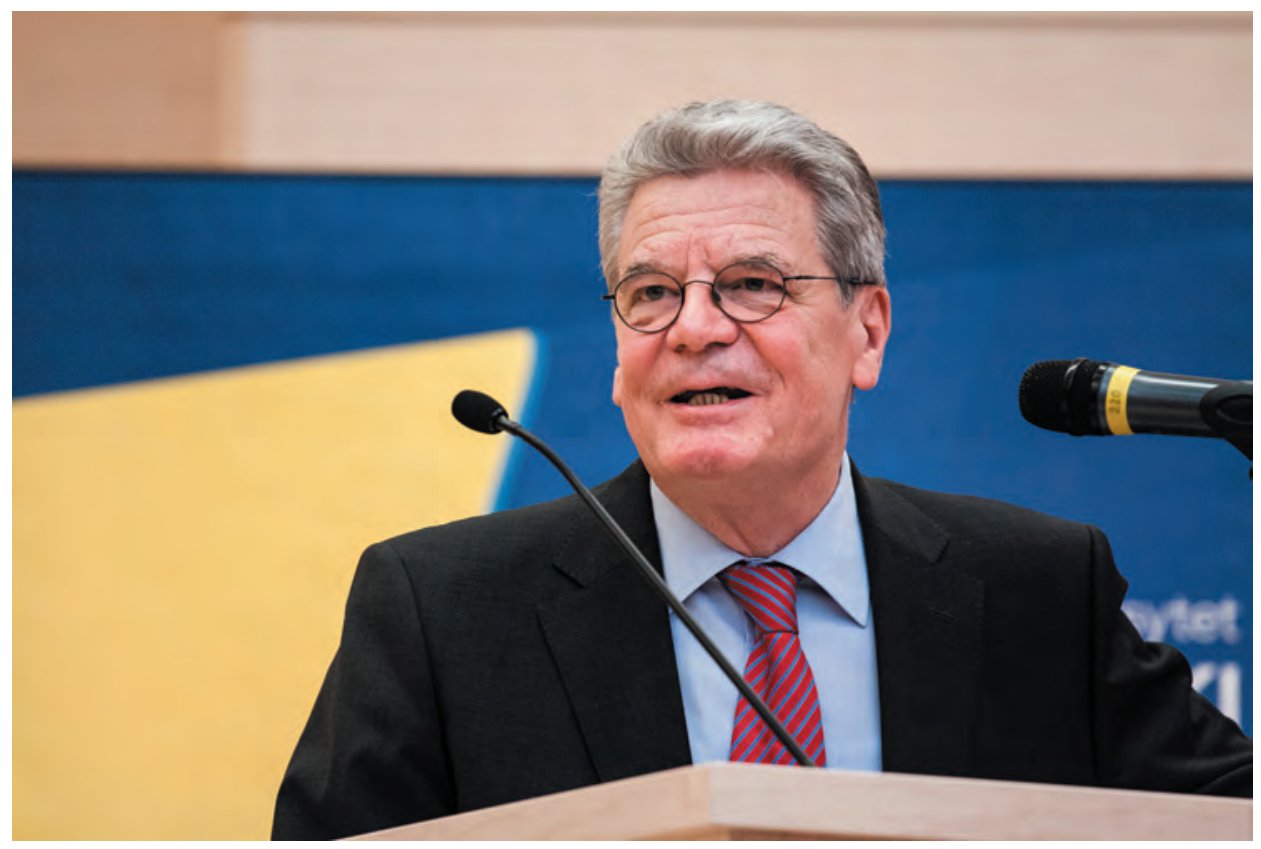

Prezydent Joachim Gauck z wizytą na WPiA. Fot. Anna Rolczak



Prezydent Vaclav Klaus z wizytą na WPiA. Fot. Anna Rolczak 


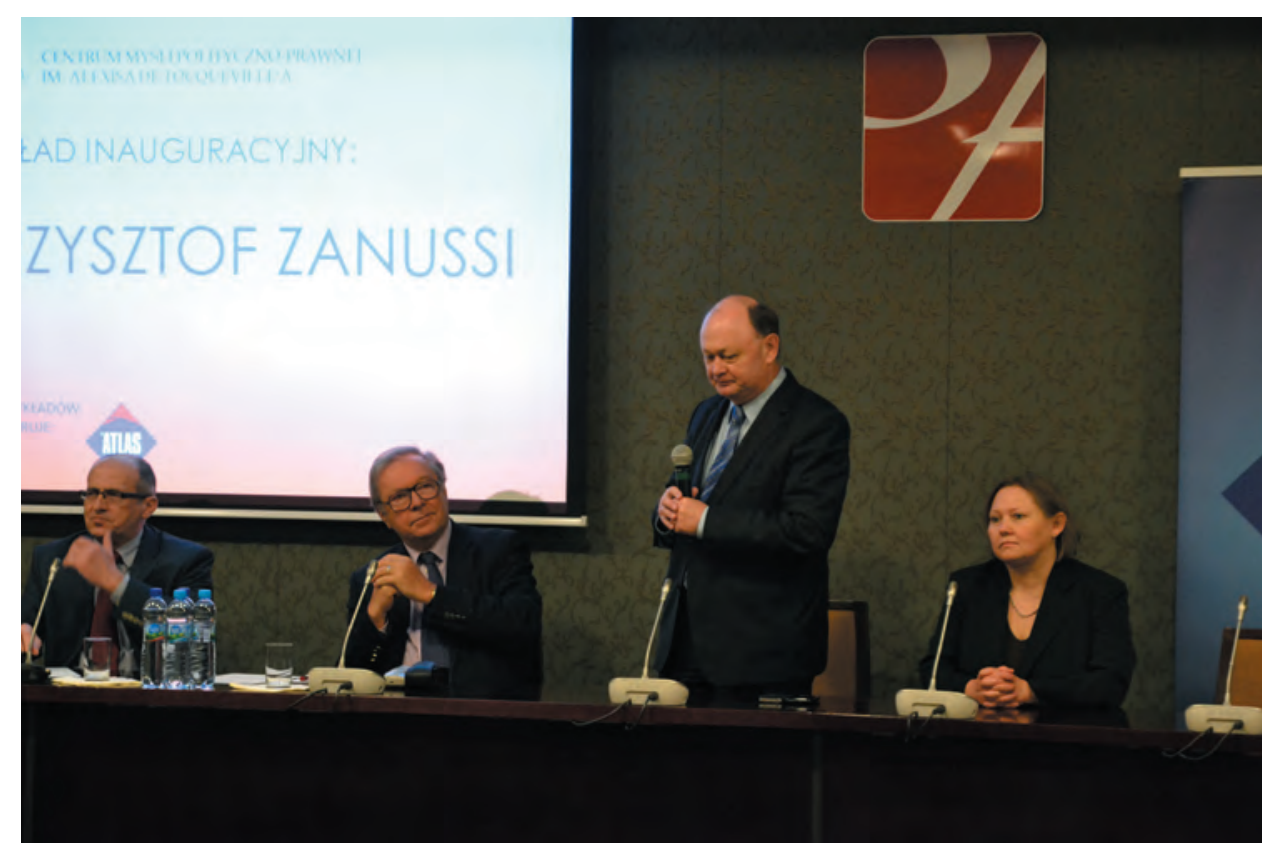

Krzysztof Zanussi z wizytą na WPiA. Fot. Anna Rolczak

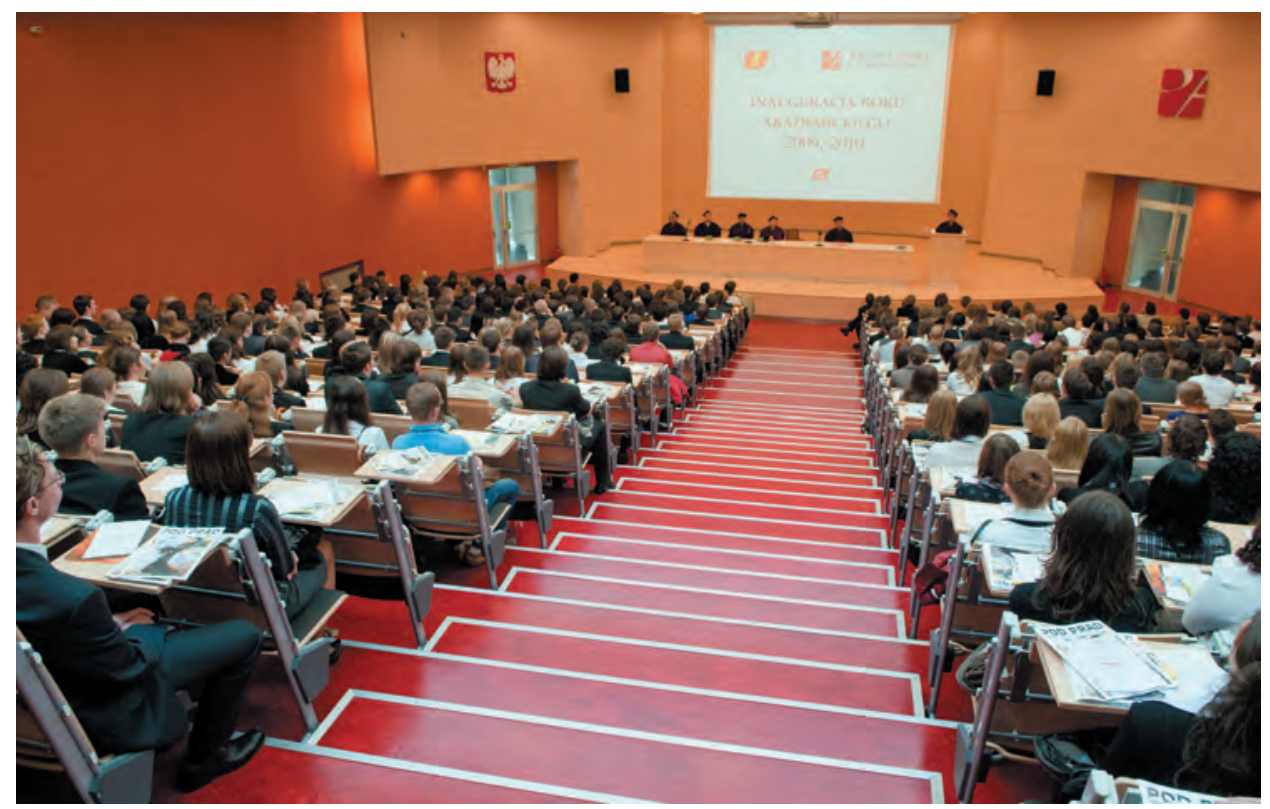

Inauguracja roku akademickiego 2009/2010. Fot. Anna Rolczak 


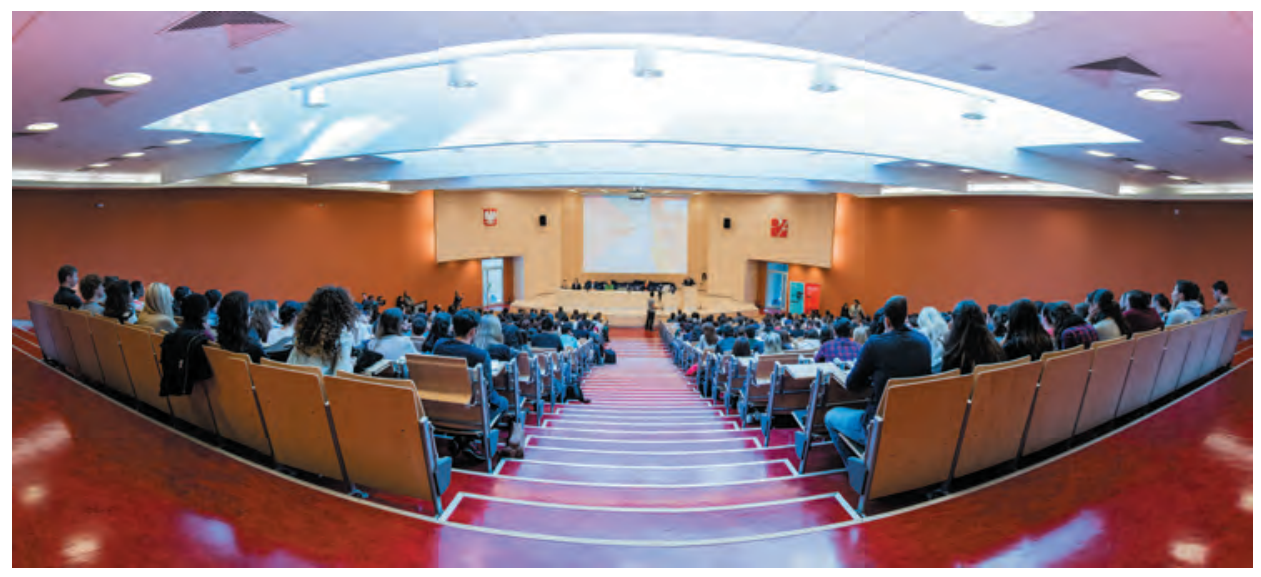

Erasmus welcome meeting 2014. Aula czerwona. Fot. Anna Rolczak

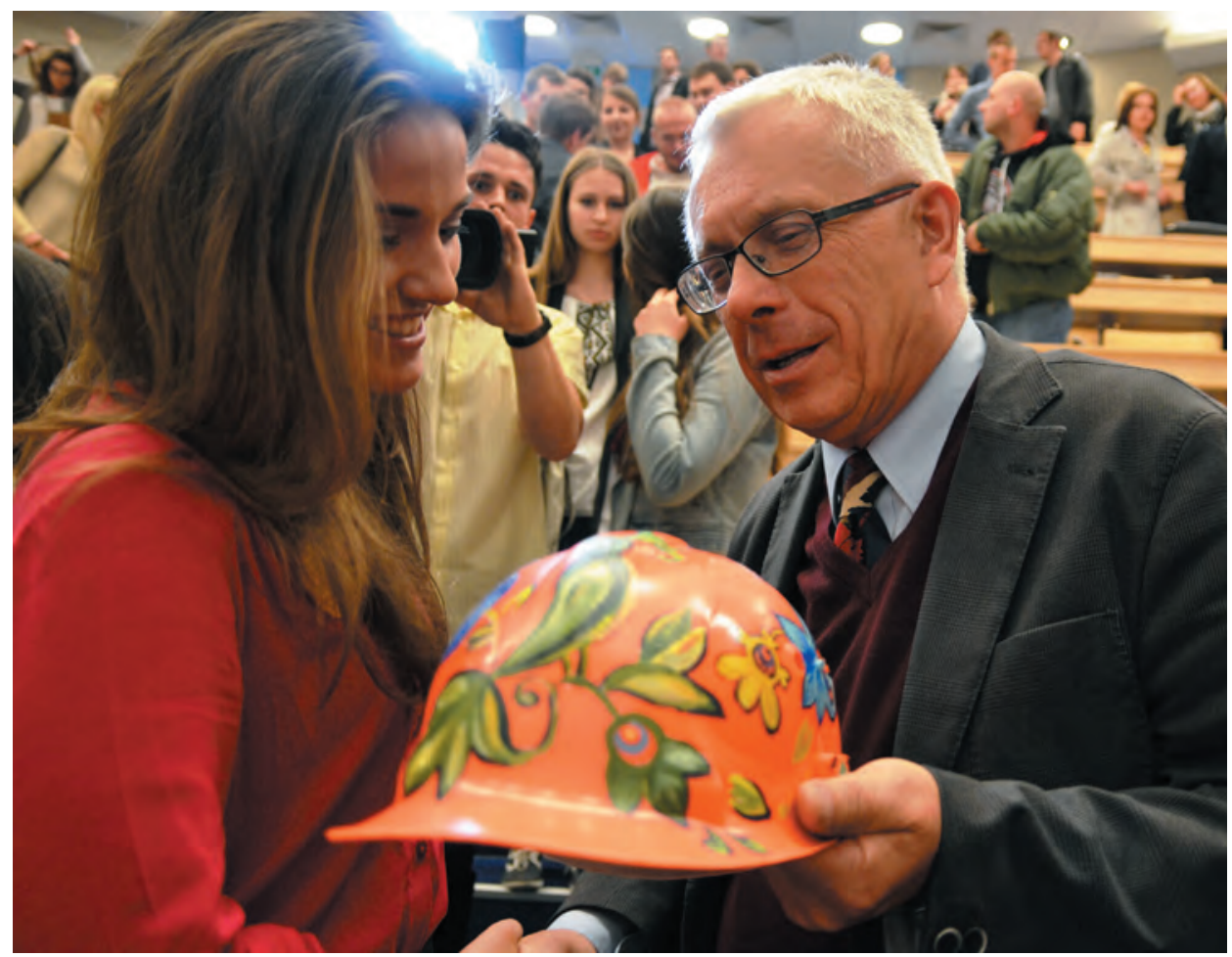

Spotkanie z Julią Maruszewską bohaterką filmu I am a Ukrainien, wolontariuszką na Majdanie (15 maja 2014 r.). Julia Maruszewska przekazuje prof. Piotrowi Daranowskiemu kask protestujących na Majdanie. Fot. Anna Rolczak 


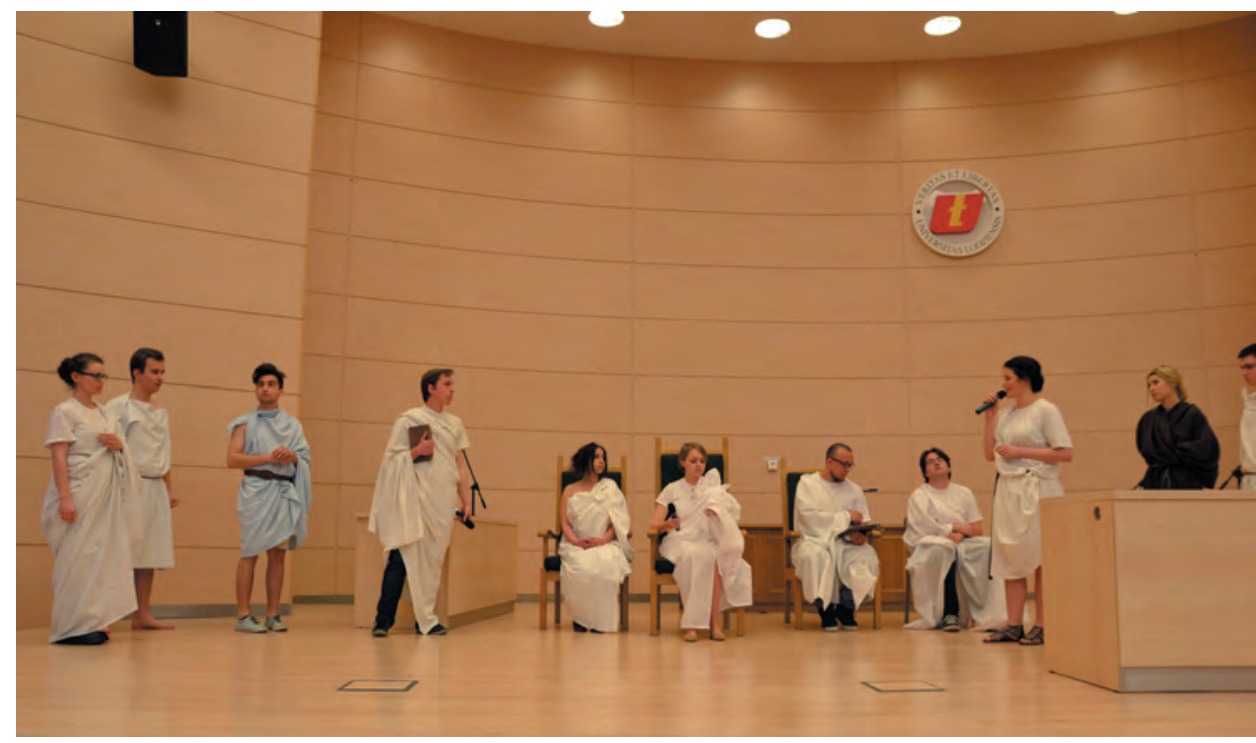

Symulacja rozprawy sądowej (proces rzymski) w ramach Festiwalu Nauki, Techniki i Sztuki, kwiecień 2014. Fot. Anna Rolczak

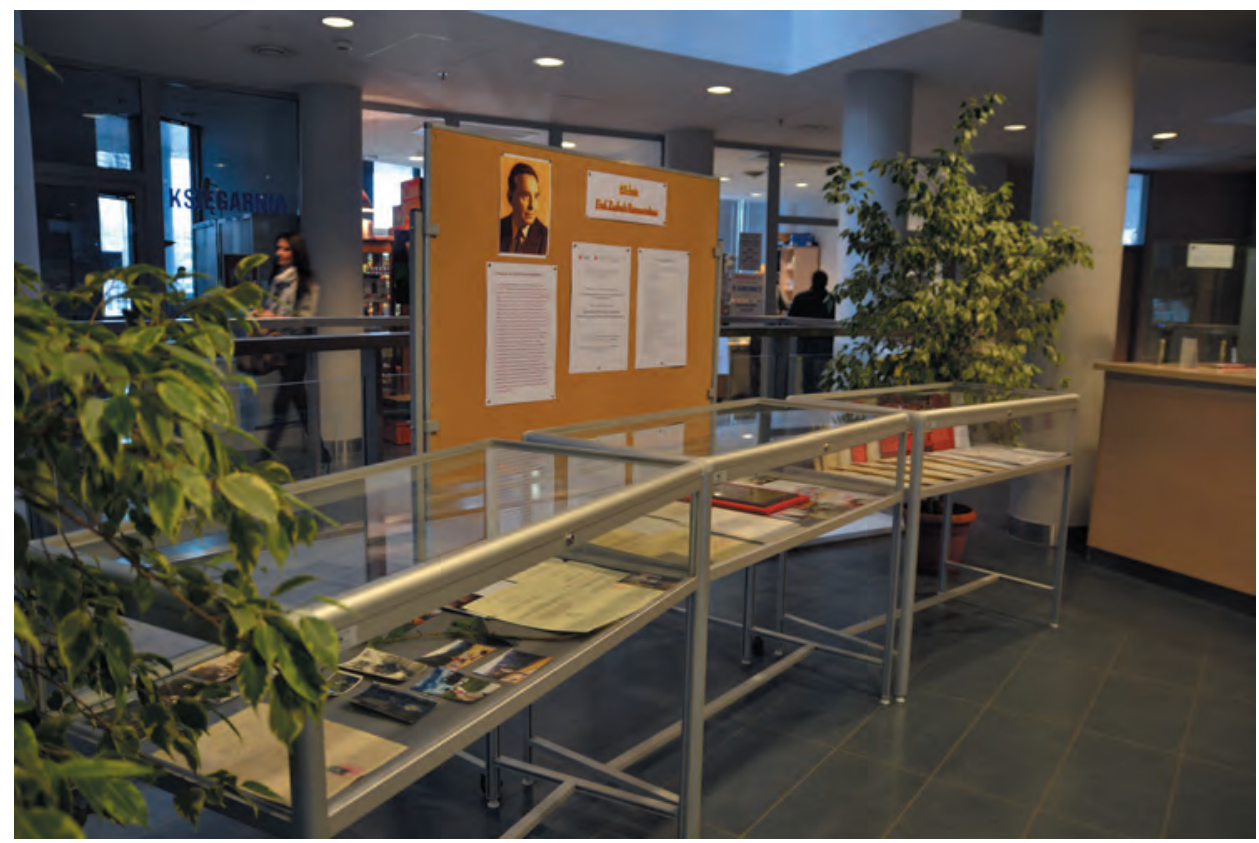

Wystawa zorganizowana z okazji jubileuszu Profesora Zygfryda Rymaszewskiego Fot. Anna Rolczak 


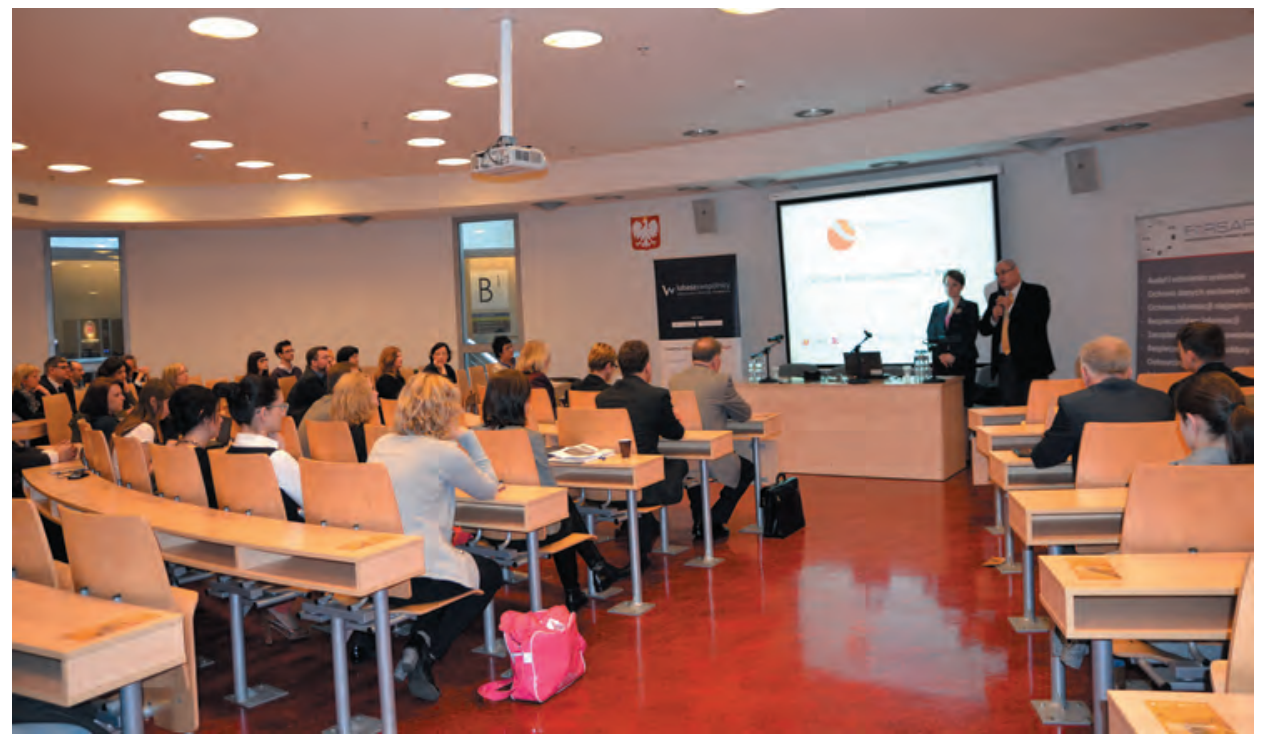

Konferencja zorganizowana przez Centrum Ochrony Danych Osobowych Fot. Anna Rolczak

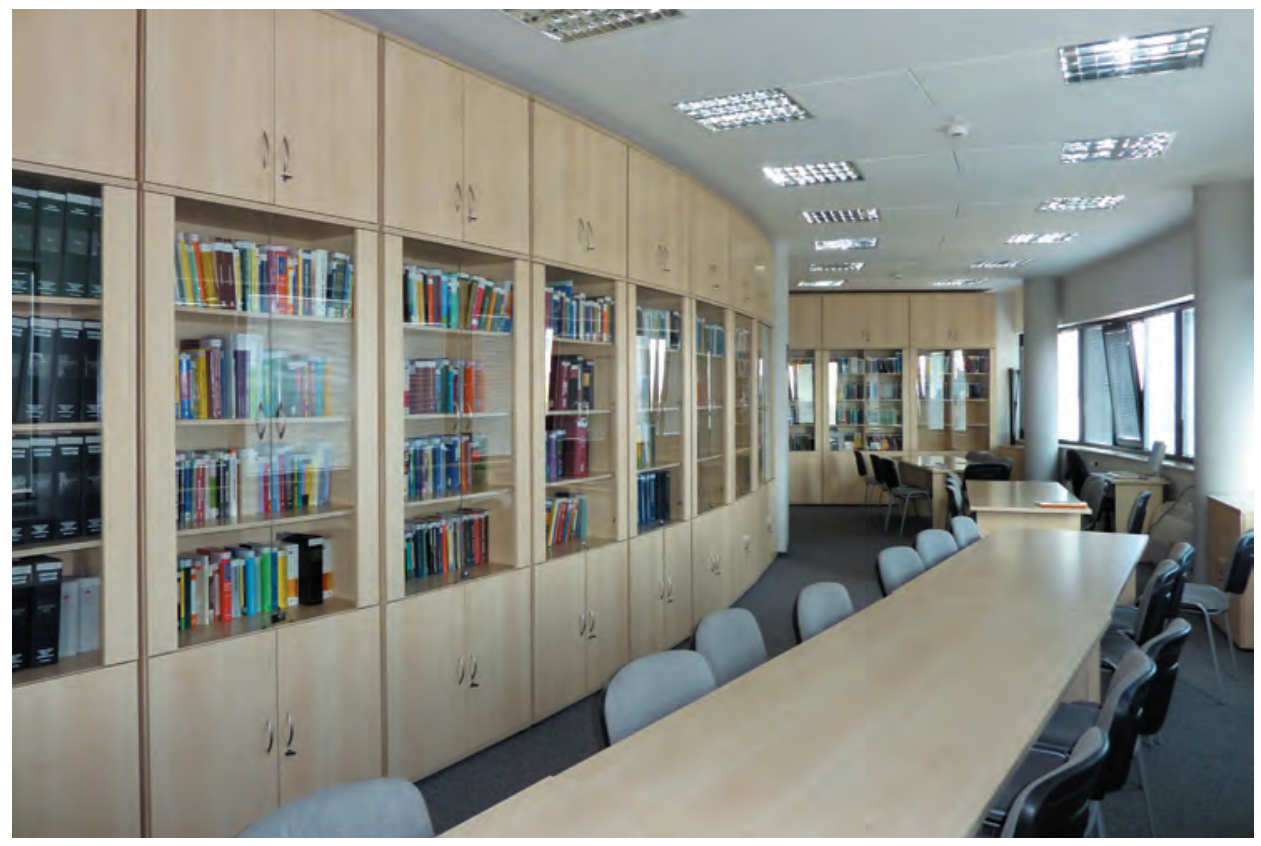

Biblioteka Centrum Dokumentacji Studiów Podatkowych. Fot. Anna Rolczak 


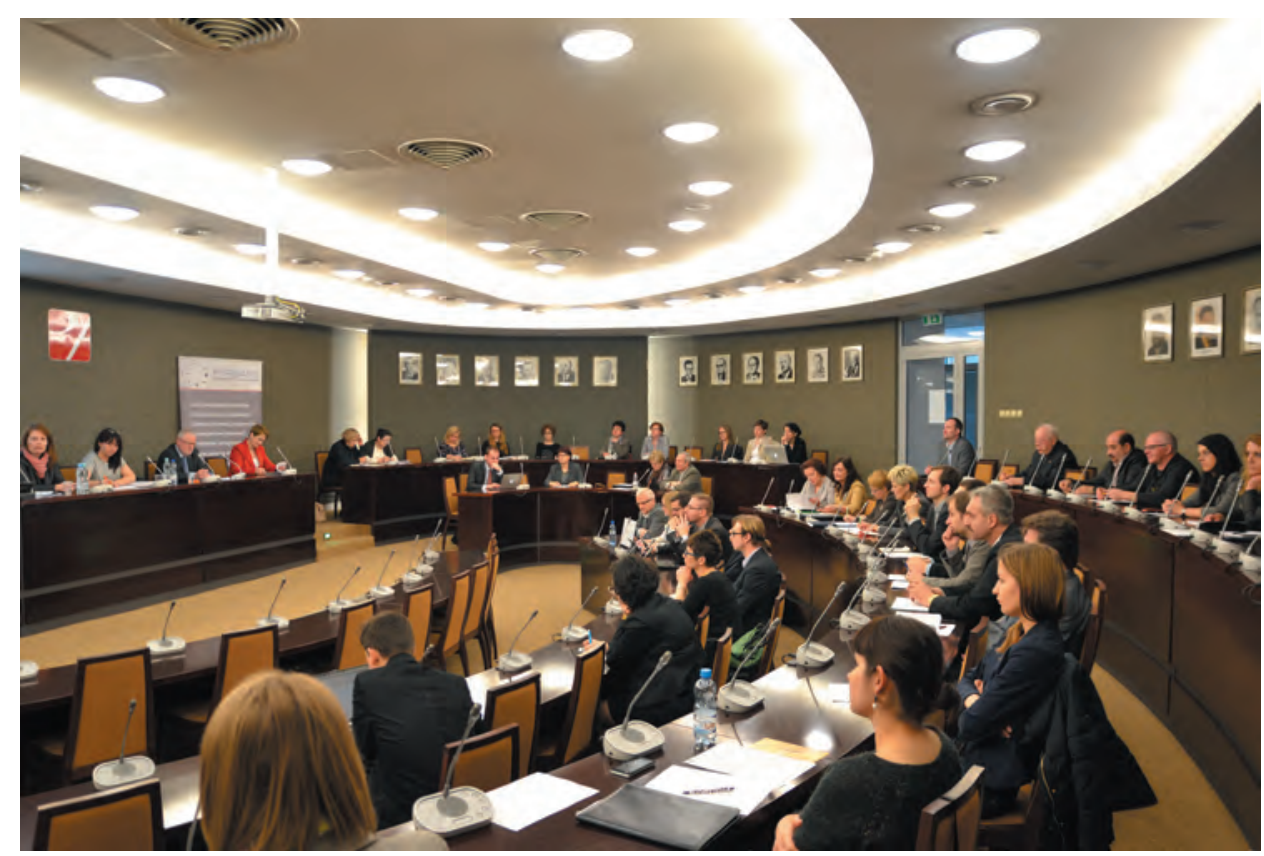

Konferencja w Sali Rady Wydziału. Fot. Anna Rolczak



Konferencja w Sali Rady Wydziału. Fot. Anna Rolczak 


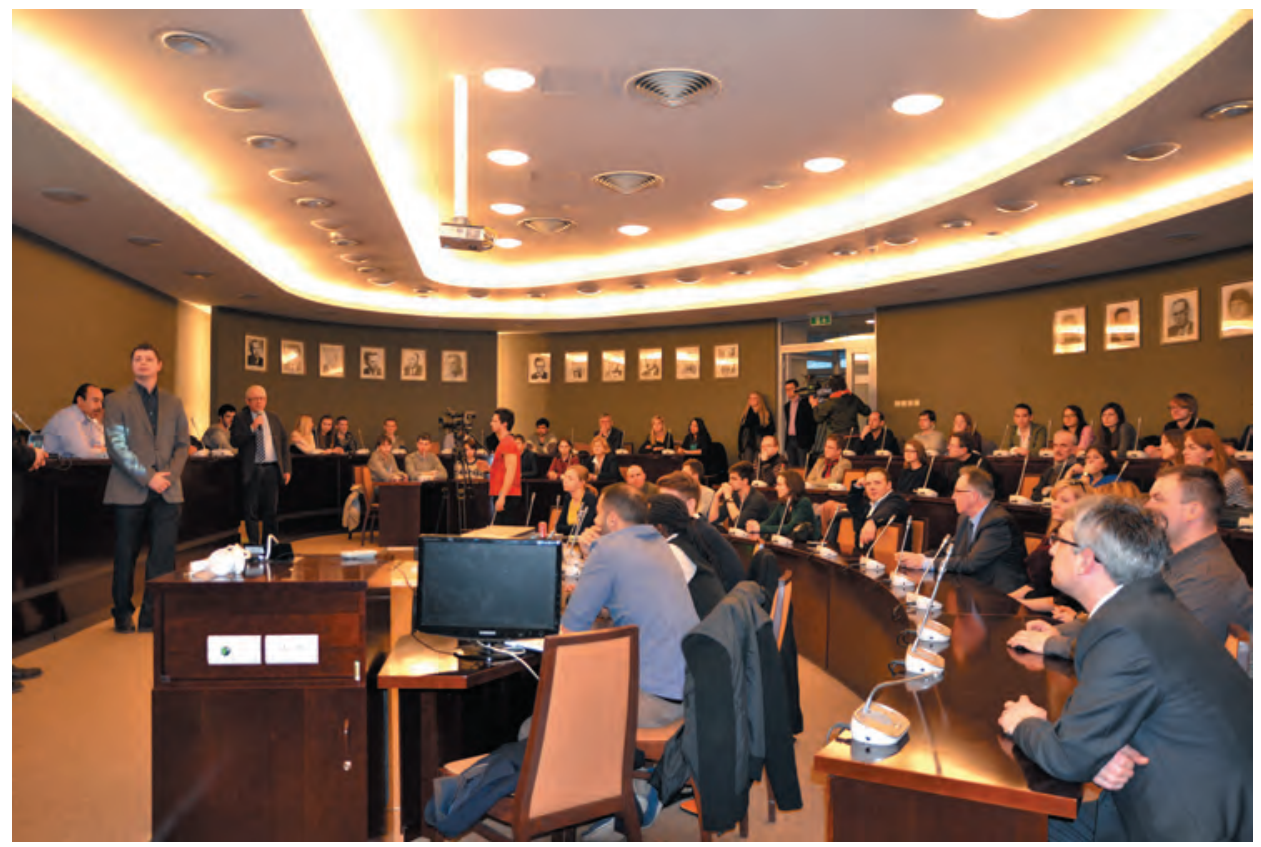

Konferencja w Sali Rady Wydziału. Fot. Anna Rolczak 


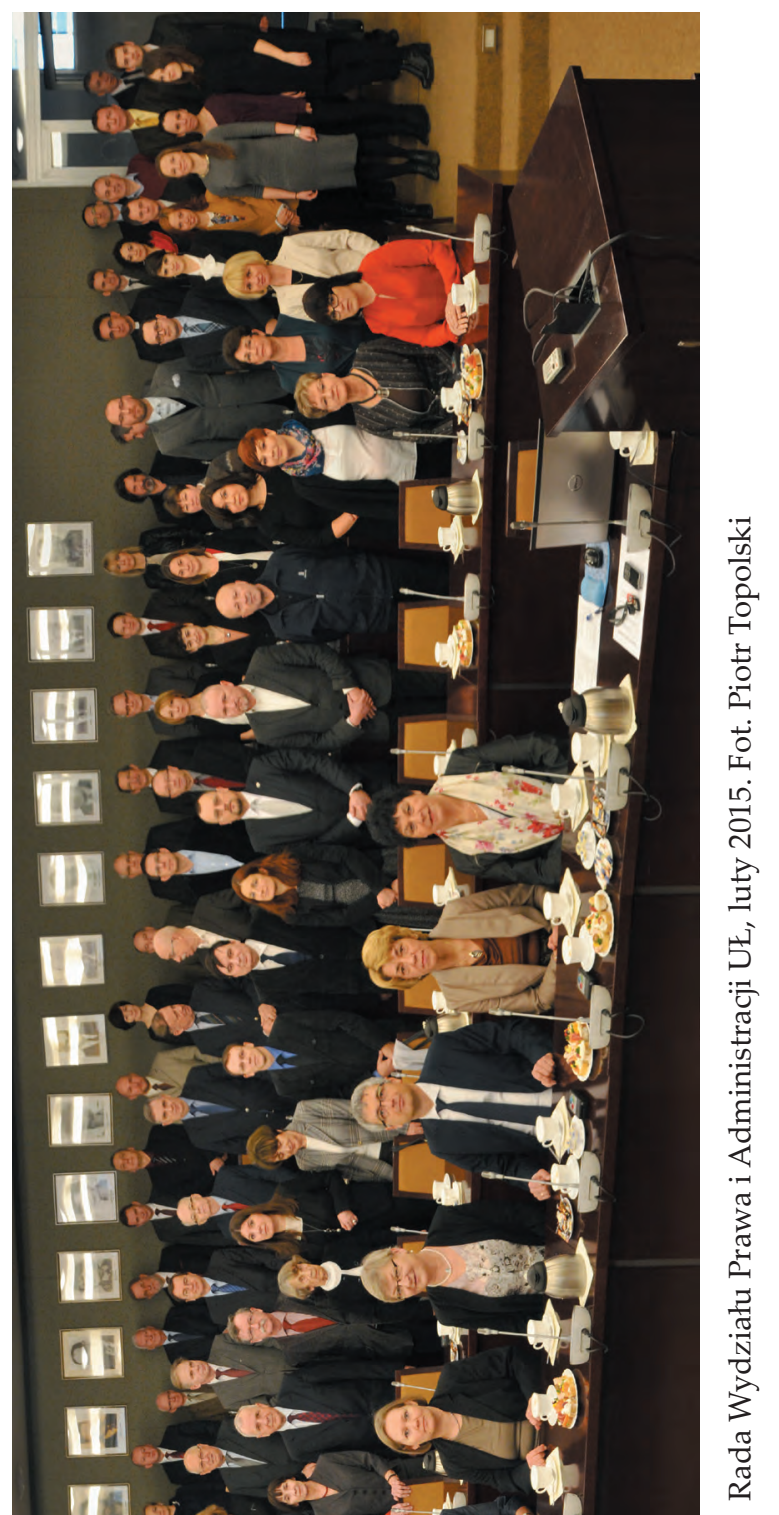




\section{Indeks osobowy}

Indeks obejmuje nazwiska i pseudonimy występujące zarówno w tekście, jak i w adnotacjach.

A

Abraham Władysław 50,

Adamczewska Genowefa 12

Adamiak Barbara 56, 57

Adamus Jan 49-54

Ajdukiewicz Kazimierz 222

Ajnenkiel Andrzej 228

Albrecht Zygmunt 114, 116

Alexa Robert 224

Andersen Irena, z domu Miecznikowska zob. Grajewska Irena

Andersen Robert 83

Andrejew I. 209

Aristides (Arystydes z Aten) 215

Augustyn, św. 93

\section{B}

Bafia Jerzy 174

Balzer Oswald 50, 53, 136, 197

Bałtruszajtys Grażyna Maria 100, 126, 129, 131,

Bandurka Mieczysław 12, 13

Banyś Tomasz A. J. 99, 129

Bar Roman Joachim 22

Baranowski Bohdan 229

Baranowski Krzysztof 229

Bardach Juliusz 23, 39, 49, 51, 52, 53, 54

Barta Janusz 219

Bartoszewski Władysław 32,

Bastid Paul 84

Batawia Stanisław 88
Bąkowski Andrzej 109

Beccaria Cesar (właśc. Cesare Bonesena markiz Beccaria) 159

Benan 215

Benedykt XV (właśc. Giacomo della Chiesa), papież 215

Biedermanna pałac 66

Bielas Katarzyna 130, 133

Bieniarz Stanisław [pseud.] zob. Śreniowski Stanisław 198

Bieńkowski Adam 14

Bierut Bolesław 198

Bierzanek Remigiusz 18, 23, 168

Bolduan Tadeusz 216

Bonawentura, św. 66

Borkowski Janusz 55-58

Bortkiewicz Filomena 59-62, 91

Bortkiewicz Stefan 59

Bossuet Jacques-Bénigne 101, 102

Bromboszcz Mateusz 129

Broniewicz Witold 35, 63-66

Buchała Kazimierz 208

Bukowiecki Stanisław 139

Byczko Szymon 139

C

Capitant René 177

Casavola Franco 94

Chałasiński Józef 22, 25, 198,

Chlamtacz Marceli 50

Chobot Edward 12 
Chróścielewski Wojciech 55

Cieślak Marian 208, 209

Colombet Claude 217

Crifó Giuliano 94

Cybulska Henryka 158

Czachórski Witold 25

Ć

Ćwiąkalski Zbigniew 208

D

Daranowski Piotr 167, 237

Dawidowicz Rajzla 95

Dawidowicz Wacław 78

Dąbkowski Przemysław 197

Demogue René 177

Dębowska-Romanowska Teresa 67, 126

Dębski Ryszard 205

Dinter Henryk Stanisław 130

Dmowski Roman 97

Domagała Michał 83, 193

Domańska Aldona 193

Domański Ludwik 15, 23

Duda-Dziewierz Krystyna 13, 24

244 Duniewska Zofia 115

Dunin Karol 139

Dworzańczyk Natalia zob. Gajl Natalia

Dybowski Aleksander Napoleon 90

Dylik Jan 11

Dylik Zygmunt Stanisław 13, 14

Dzierzgwa Hieronim 23

E

Ehrlich Stanisław 23

Ereciński Tadeusz 152

Estreicher Stanisław 197

\section{F}

Falenciak Jerzy 134

Fijałkowska Lena 135

Fischer Ludwig 174

Forster Albert 174

Françon Andre 217

Frey Helena zob. Weisblum Helena

Frontinus, mierniczy rzymski 103

G

Gaius (Gajusz), jurysta rzymski 103

Gajl Janusz 67

Gajl Karina 67
Gajl Natalia 17, 18, 26, 27, 36, 37, 67-73, 126

Gajl Olaf 67

Gall Anonim 51

Garçon Emil 155

Gauck Joachim 32, 235

Gąsiorowska Natalia 13, 198

Goeth Amon 174

Góral Zbigniew 41, 105, 119, 183, 189, 231

Górecki Dariusz 189

Górski Marek 231

Grabski Andrzej Feliks 49

Grabski Marian 88

Graczyk Bronisław 75-81

Graczyk Jadwiga, z domu Mieszkalska 75

Graczyk Kazimierz 75

Grajewska Elżbieta 87

Grajewska Irena 83-86

Grajewski Adam 87

Grajewski Henryk 87-92

Gramatic Filippo 157

Greiser Arthur 174

Grzegorczyk Tomasz 143, 173

Gwiazdomorski Jan 177

$\mathbf{H}$

Halphen Louis 136

Hašek Jaroslav 58

Hausmaninger Herbert 94

Heda Antoni 205

Hejnosz Wojciech 90

Herka Zuzanna 40

Hilarowicz Tadeusz 24

Hoess Rudolf 174

Hołub I. 214

Horoszowski Paweł 26

Hübner Piotr 25

Husserl Edmund 221

I

Ingarden Roman 221

Izdebski Zygmunt 17, 27, 36

J

Jackiewicz Mieczysław 214

Jagieła Józef 63

Jakubowski Ireneusz 93, 104, 134

Jamontt Janusz 15, 22, 23

Jarra Eugeniusza 100, 101

Jaworska-Dębska Barbara 40, 75, 115

Jaworski Władysław 228 
Jaźwiński Andrzej 164

Jedlicki Marian 136

Jędrzejewska Maria 110

Jodłowski Jerzy 25, 110

Jońca Maciej 131

Justynian I Wielki, cesarz rzymski 103

\section{K}

Kafel Salezy OFM CAP 66

Kalinowski Stefan 174

Kallas Marian 228

Kamieńska E. 17

Karcz-Kaczmarek Maria 113

Kasiński Michał 41

Katner Wojciech 40

Kaute Wojciech 49

Kąkol Kazimierz 24

Kelsen Hans 225

Kiciński Franciszek 12

Kieniewicz Stefan 60

Klafkowski Alfons 195

Klanowski Władysław 214

Klarner Czesław 125

Klaus Vaclaw 32, 235

Klein Alfred 149

Klima J. 102

Kłoskowska Antonina 15, 158

Kodrębski Jan 21, 22, 23, 93-98

Kołakowska L. 149

Komorowski Bronisław 32, 33, 234

Konic Henryk 139

Koprowski Józef 164

Koranyi Karol 23, 197, 198

Kornat Marek 213, 214

Korporowicz Łukasz Jan 99, 129

Koschembar-Łyskowski Ignacy 131

Kosik Jan 150

Kosikowski Cezary 147, 148

Kostecki A. 126

Kostiuszko (Kostyushko) Ivan Ivanovich 60

Kostwiński Marcin 109, 171

Kotarbiński Tadeusz 14, 15, 34

Kowalczyk Roman 27

Kozłowski Eligiusz 129

Kozłowski T. 100

Kozubski Władysław 131

Krukowski Stanisław 228

Krzynówek Jerzy 101

Kuciński Julian 11

Kulesza Ewa 41
Kunderewicz Cezary 17, 36, 93, 99-104

Kunderewicz Teresa CR 104

Kupczyński T. 14

Kurnatowski Henryk 12

Kurowski Leon 124, 125

Kutrzeba Stanisław 197

L

Lande Jerzy 221, 222

Lejman Witold 14

Lelental Stefan 9, 37

Lelewel Joachim 53

Leonieni Mikołaj 159

Leśnodorski Bogusław 23

Lewandowski Henryk 23, 25, 36, 105-107, 119,183

Lewaszkiewicz-Petrykowska Biruta 18, 25, 27, 39, 40, 41, 97, 98, 149, 177, 217, 234

Lewicki Marek 115

Liebs Detlef 94

Lipit-Isztar, król sumeryjski 102

Lisiewska Danuta 111

Lisiewska Hanna 111

Lisiewska Ludwika 111

Lisiewski Marian 109-111, 171

Liszewska Agnieszka 147

Liszewski Stanisław 11

Liszt Franciszek von 155, 159

Litwin Jerzy 18

Litwin Józef 26, 60, 78, 110, 113-117

Litwin Justyna z Sonenbergów 113

Litwin Rafał 113

Loga Jerzy 119-121

Longchamps Franciszek 117

Lubowicki Jerzy Telesfor 26, 27, 68, 123-127

Lutostański Karol 139

Ł

Łapicki Andrzej 133

Łapicki Borys 18, 22, 24, 34, 93, 101, 129-134

Łapicki Hektor 129

Łętowska Ewa 23

Łętowski Janusz 71

Łochowski Stanisław 102

Łoś Leon 11

Łoza Stanisław 23, 227 


\section{M}

Maciejewski Marek 95

Makowski Wacław 139

Maliszewska Halina 40

Małecki Jerzy 124, 125

Marciniak Andrzej 63

Markiewicz Ryszard 218

Markowski Bolesław 125

Marszał Maciej 95

Maruszewska Julia 237

Matuszewski Ignacy 135

Matuszewski Jacek 17, 49, 54, 59

Matuszewski Józef 90, 135-137

Miastkowski Leszko 23

Michalski Jerzy 125, 228

Mioduski Kryspin 174

Mogilnicki Aleksander 15, 139

Montlak Emil 114

Mościcki Ignacy 160, 213

Mrozowska Hanna 183

Mrozowski K. 183

Muszkowski Jan 12

Mycielski Andrzej 195

$246 \mathbf{N}$

Namitkiewicz Jan 15, 18, 23, 24, 25, 26, 139-141

Napierała Jacek 149

Nesterowicz Mirosław 164

Niboyet Jean P. 177

Nisenson Jerzy 173

Nörr Dieter 94

Nowacki Józef 18, 116

\section{$\mathrm{O}$}

Obtułowicz Zofia zob. Wróblewska Zofia

Ojrzyńska Maria 12

Olejniczak-Szałowska Ewa 41

Olszewski Henryk 133

Olszewski Marek 37, 143-145, 174

Olszowy Witold 147-148

Opaliński Łukasz 100, 101, 102

Oppenauer Krystyna 197

Ossowska Irena 198

Ossowski Stanisław 198

\section{$\mathbf{P}$}

Paciorkowski Marcin 102

Paderewski Ignacy Jan 228

Pajor Tomasz 40, 149-154
Patek Stanisław 155

Pawlikowski Tadeusz 12

Perelman Chaïm 150

Peretiatkowicz Antoni 22

Petrażycki Leon 130, 131

Piątowski Józef Stanisław 23

Pieńkowski Stefan 100

Pikulska-Radomska Anna 93, 95, 129, 130, 131, 133

Pikulska-Robaszkiewicz Anna zob. Pikulska-Radomska Anna

Piłsudski Józef 97, 100, 139, 161

Piniński Leon 132

Pławski Stanisław 17, 26, 36, 138

Płażewska Magdalena 175

Polikarp, św. 214

Popławski H. 18

Poźniak-Niedzielska Maria 218

Promińska Urszula 41, 163

Przybyłowski Kazimierz 23

Przyłuski Jakub 91

Puś Wiesław 231

Pyziak-Szafnicka Małgorzata 232

R

Rajkowski Rudolf 18

Rakowski Maciej 201

Rappaport Emil Stanisław 15, 22, 139, 155-161

Rappaport Feliks 161

Rappaport Justyna 158

Rau Zbigniew 93, 95

Redzik Adam 139

Rembieliński Andrzej 163-166

Ridder Helmut 194

Rolczak Anna 29, 234, 235, 236, 237, 238, $239,240,241$

Romek Zbigniew 197

Rotocki Zbigniew 17, 18, 167-169

Rowińska Helena, z domu Jóźwiak 171

Rowiński Tadeusz Czesław 171-172

Rowiński Zdzisław 171

Roztworowski Michał 228

Rybicki Zygmunt 78

Rydz Jan 231

Rymaszewski Zygfryd 36, 49, 52, 53, 104, 130, 133, 135, 202, 239

Rzetelska Anna 163 
S

Sadowski Mirosław 221

Sawicki Jerzy 25

Sawicki Witold 90

Schaff Adam 23

Sczaniecki Michał 136

Seweryński Michał 23, 39, 231

Siedlecki Władysław 23, 171

Siewierski Andrzej 175

Siewierski Mieczysław 15, 17, 22, 25, 143, 144, 173-175, 206

Skarbek Fryderyk 185

Skąpski Józef 150

Skoczylas Andrzej 57

Skotnicki Krzysztof 41, 227

Skrzeszewski Stanisław 12

Skubała-Tokarska Zofia 21

Służewska Zuzanna 101

Smoktunowicz Eugeniusz 116, 117

Smoleński Dionizy 11

Smoliński A. 141

Sobeski Michał 22

Sobociński Władysław 89, 91, 92

Sokołowski Czesław, ks. 213

Sondel Janusz 101

Splett Carl Maria, bp 216

Stahl Małgorzata 41, 115

Starościak Jerzy 78

Stawiński Eugeniusz 88

Stępień Bartek 34

Suligowski Adolf 139

Supera Maria 126

Szary [pseud.] zob. Heda Antoni

Szczepański Jan 51

Szczerba Jacek 130, 133

Szerer M. 15

Szewczyk Maria 208

Szpilfogiel Josel 96

Szpilfogiel Markus 95

Szpilfogiel Rajzla, z domu Dawidowicz 95

Szpilfoglów rodzina 95

Szpilfoglów-Kodrębskich rodzina 95

Szpunar Adam 17, 18, 23, 25, 26, 27, 37, 110, 151, 166, 177-181, 218

Sztombka Aldona 40

Szubert Wacław 10, 17, 18, 22, 23, 24, 26, $27,43,45,183-191$

Szulc Tadeusz 197, 213

Szydłowski Krzysztof 52,

Szymański Jan Maria 190
Szymański Zdzisław Zygmunt 18, 189-191

Szymczak Tadeusz 18, 24, 36, 83, 133, 193-196, 229

Ś

Śliwiński Stanisław 173

Śliwowski Jerzy 157

Śmiech Witold 11

Śreniowska Krystyna zob. Oppenauer Krystyna

Śreniowski Stanisław 18, 23, 59, 88, 89, 90, 92, 93, 197-199

Świderski Zbigniew 41

\section{$\mathrm{T}$}

Taubenschlag Rafał 101, 102

Taylor Edward 124, 125

Thatcher Margaret 32

Tokarczyk Roman 133

Topola [pseud.] zob. Waszczyński Jan Aleksander

Topolski Piotr 232

Tylman Janusz 18, 27, 78, 143, 144, 174

U

Urbanik Jakub 101

Ur-Nammu, król sumeryjski 102

Urukagina, władca Lagasz 102

V

Vetulani Adam 197

Vieweger Andrzej 13

Vieweger Anna 13

Vieweger Hanna (Anna), z domu Dobek 13

Vieweger Jadwiga 13

Vieweger Maria 13

Vieweger Oskar 13

Vieweger Tadeusz 13

Vieweger Teodor Mieczysław 11, 12, 13, 14,21

Vieweger Tomasz 13

Viney Geneviev 217

W

Wacke Andreas 94

Waldo Barbara 52, 201-203

Waldo Eugenia, z domu Wełnicka 201

Waldo Stefan 201

Waldstein Wolfgang 94

Walicki Jacek 95 
Waltoś Stanisław 208

Waszczyński Jan 15, 18, 22, 36, 37, 157, 158, 205-208

Weisblum Helena, z domu Frey 197

Weisblum Józef 197

Weisblum Stanisław zob. Śreniowski Stanisław

Weralski Marian 126

Wilanowski Bolesław 12, 15, 18, 22, 24, 25, 213-216

Winiarz Jan 164

Wiszniewicz Joanna 95

Wlaźlak Katarzyna 113

Wojciechowska Paulina ze Szwarców 59

Wojciechowski Franciszek 59

Wojciechowski Zygmunt 135, 195, 198

Wojnicka Elżbieta, z domu Kaczorowska 217-220

Wołodkiewicz Witold 101, 131

Wróblewska Krystyna, z domu Hirschberg 221

Wróblewska Maria 227

Wróblewska Teodozja, z domu Bossowska 227
Wróblewska Zofia 227

Wróblewski Adam 227

Wróblewski Andrzej 221

Wróblewski Bronisław 221

Wróblewski Ferdynand 227

Wróblewski Jerzy 158, 221-226

Wróblewski Stanisław 227

Wróblewski Wincenty 227

Wróblewski Władysław 227-230

Wycech Czesław 14

Z

Zabłocka Maria 101, 129, 131, 132

Zajączkowski Stanisław Franciszek 215

Zanussi Krzysztof 32, 236

Zawadzki Józef 213, 214

Zimmermann Anna Marian 113

Zirk-Sadowski Marek 25, 221

Zoll Andrzej 208

Zoll Fryderyk 177

Zybajło L. 214

$\dot{Z}$

Żabicki Artur 22, 23, 25 